NUREG-0940

Vol. 15, No. 2, Part 1

Individual Actions

\title{
Enforcement Actions: Significant Actions Resolved Individuals Actions
}

\section{Semiannual Progress Report} July - December 1996

Manuscript Completed: April 1997

Date Published: April 1997

Office of Enforcement

U.S. Nuclear Regulatory Commission

Washington, DC 20555-0001

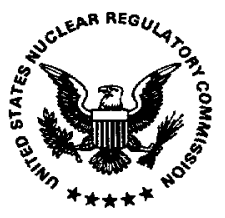




\section{DISCLAIMER}

This report was prepared as an account of work sponsored by an agency of the United States Government. Neither the United States Government nor any agency thereof, nor any of their employees, make any warranty, express or implied, or assumes any legal liability or responsibility for the accuracy, completeness, or usefulness of any information, apparatus, product, or process disclosed, or represents that its use would not infringe privately owned rights. Reference herein to any specific commercial product, process, or service by trade name, trademark, manufacturer, or otherwise does not necessarily constitute or imply its endorsement, recommendation, or favoring by the United States Government or any agency thereof. The views and opinions of authors expressed herein do not necessarily state or reflect those of the United States Government or any agency thereof. 


\section{DISCLAIMIER}

Portions of this document may be illegible in electronic image products. Images are produced from the best available original document. 


\section{ABSTRACT}

This compilation summarizes significant enforcement actions that have been resolved during the period (July - December 1996) and includes copies of Orders and Notices of Violation sent by the Nuclear Regulatory Commission to individuals with respect to these enforcement actions. It is anticipated that the information in this publication will be widely disseminated to managers and employees engaged in activities licensed by the NRC. The Commission believes this information may be useful to licensees in making employment decisions. 



\section{CONTENTS}

Page

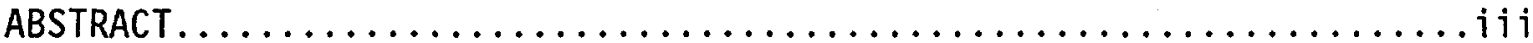

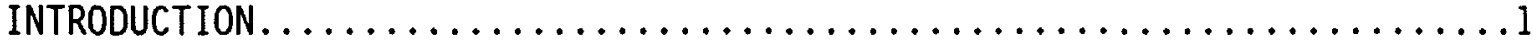

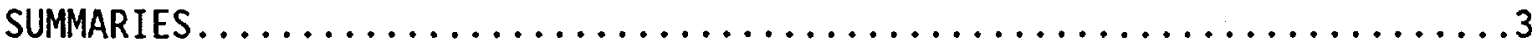

ORDERS (* cases printed in previous volumes)

* Nash Babcock

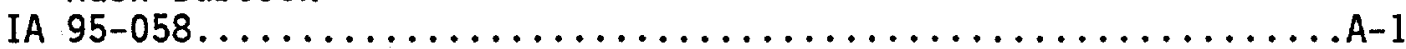

* James Bauer

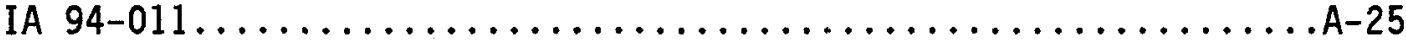

* Paul A. Bauman

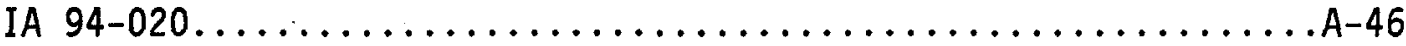

* Michael J. Berna

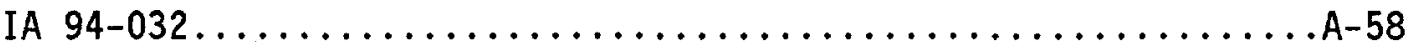

* Jerome E. Bodian, M.D.

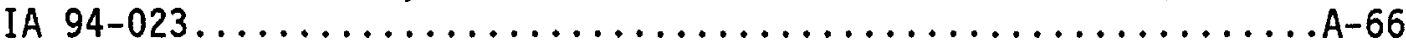

* Eugene Bolton

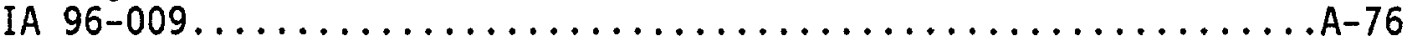

* John W. Boomer

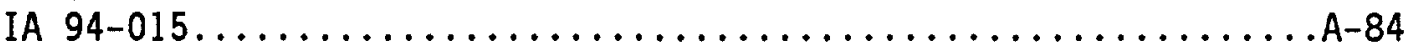

* Richard J. Gardecki

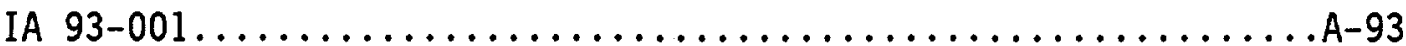

Juan Guzman

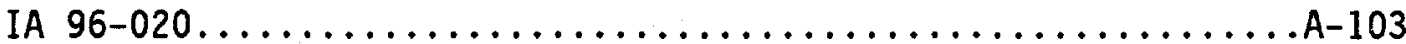

Mark Jensen

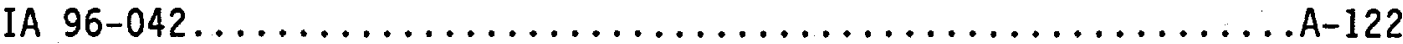

* William Kimbley, Joan Kimbley

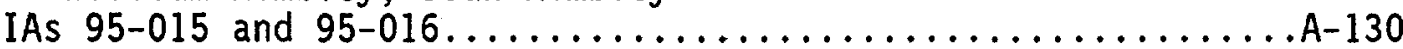

* Larry S. Ladner

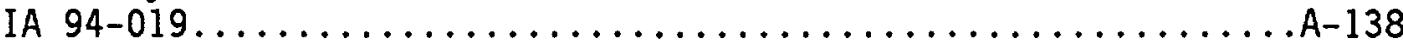

* Daniel J. McCool

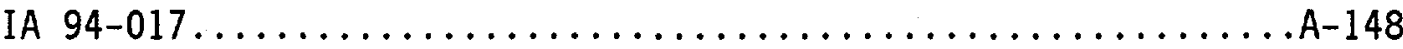

* Donald J. McDonald, Jr.

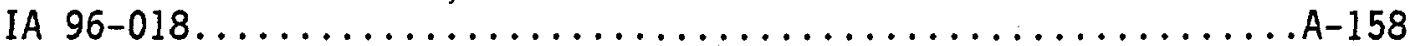

* Stephen Mignotte

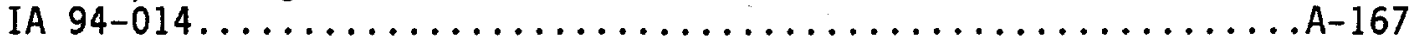

NUREG-0940, PART I V 
CONTENTS (Continued)

* Sean G. Miller

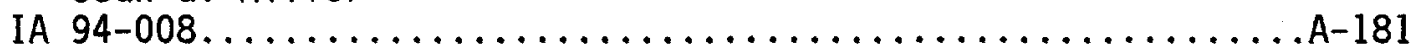

* Richard E. Odegard

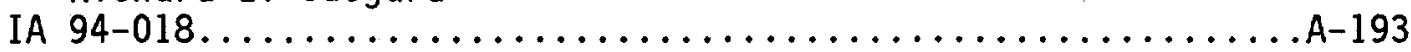

Jesus 0sorio

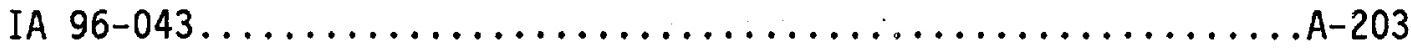

* Hartsell S. Phillips

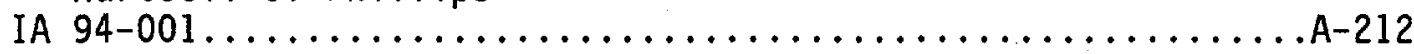

* Douglas D. Preston

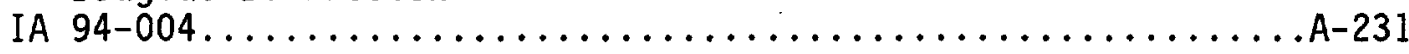

* Guillermo Velasquez, M.D.

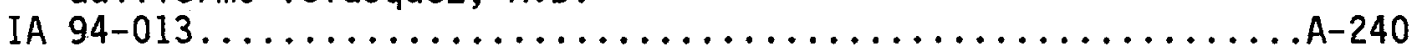

* David Tang Wee

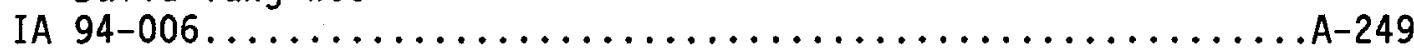

* Rex Allen Werts

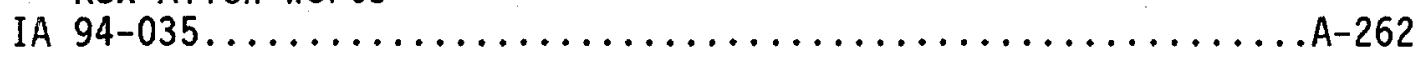

* Larry D. Wicks

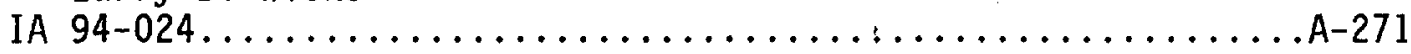

* Marc W. Zuverink

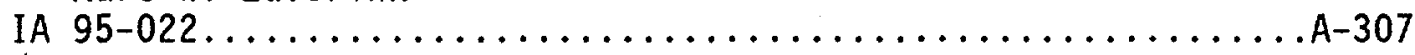

NOTICES OF VIOLATION

Robert C. Allen

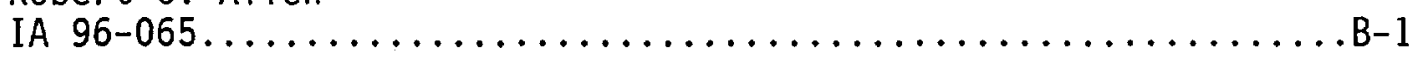

Steven R. Allent

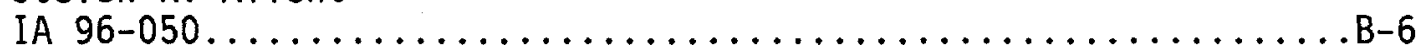

Richard $L$. Balcom
IA $95-042 \ldots \ldots \ldots \ldots \ldots \ldots \ldots \ldots \ldots \ldots \ldots \ldots \ldots \ldots \ldots \ldots \ldots \ldots \ldots \ldots$

Robert Beltran

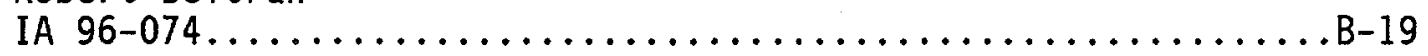

Wil 11 iam $E$. Breen
IA $96-049 \ldots \ldots \ldots \ldots \ldots \ldots \ldots \ldots \ldots \ldots \ldots \ldots \ldots \ldots \ldots \ldots \ldots \ldots$

Kirk H. Carroll

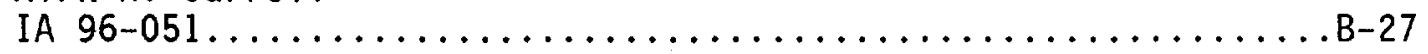

Richard Fentiman

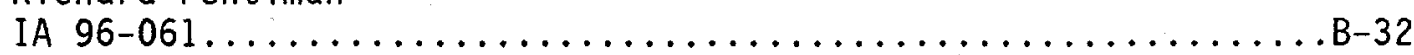


Gregory L. Goodchild

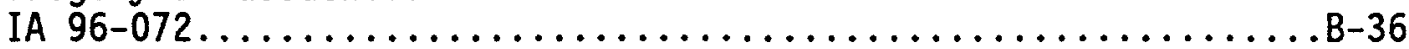

Richard M. Gracin

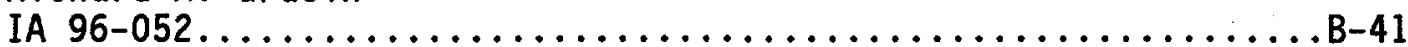

David A. Harris

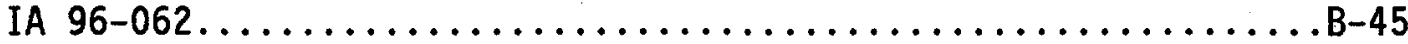

Roger E. Jones

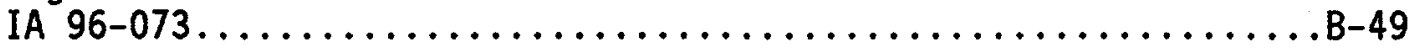

Michael Muszynski

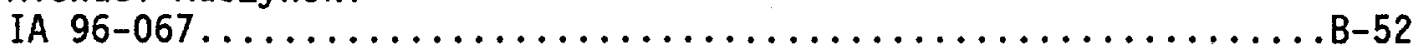

Kipp Rustenholtz

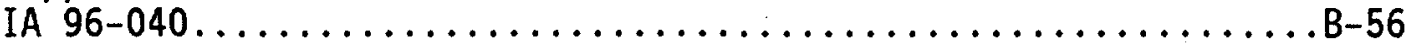




\section{ENFORCEMENT ACTIONS: SIGNIFICANT ACTIONS RESOLVED INDIVIDUAL ACT,IONS \\ July - December 1996}

\section{INTRODUCTION}

This issue and Part of NUREG-0940 is being published to inform all Nuclear Regulatory Commission (NRC) licensees about significant enforcement actions taken against individuals for the second half of 1996. Enforcement actions are issued in accordance with the NRC's Enforcement Policy, published as NUREG-1600, "General Statement of Policy and Procedure for NRC Enforcement Actions."

In promulgating the regulations concerning deliberate misconduct by unlicensed persons (55 FR 40664, August 15, 1991), the Commission directed that a list of all persons who are currently the subject of an order restricting their employment in licensed activities be made available with copies of the orders. These enforcement actions will be included for each person as long as the actions remain effective. The Commission believes this information may be useful to licensees in making employment decisions.

The NRC publishes significant enforcement actions involving reactor and materials Iicensees as Parts II and III of NUREG-0940, respectively. 

SUMMARIES

ORDERS

Nash Babcock IA $95-058$

An Order was issued December 1, 1995 prohibiting the individual and the companies (Five Star Products, Inc., Construction Products Research, Inc.,) from providing products and services asserted to meet 10 CFR Part 50, Appendix $B$, or Part 21 requirements until certain provisions specified in the Order are satisfied. The Order was based on Mr. Babcock's and the above companies' refusal to permit NRC inspection of CPR's test facility and the provision of inaccurate and incomplete information to the NRC in violation of 10 CFR 50.5(a)(2). Following the issuance of the Order, the companies and the individual and the NRC staff entered a settlement agreement that essentially implemented the Order.

James Bauer, M.D. IA 94-011

An Order Prohibiting Involvement in NRC Licensed Activities (Effective Immediate1y) was issued May 10, 1994. The Order prohibited the above individual from being involved in NRC-1icensed activities for a period of five years and required him to notify the NRC of any involvement for a period of two years thereafter. The Order was based on (1) the individual's performance of activities with a strontium-90 source that were not authorized by the license, (2) failure to provide complete and accurate information to NRC inspectors, and (3) failure to cause a radiation survey to be performed as required by 10 CFR 20.201, which led to a significant misadministration to a patient, as well as unnecessary radiation exposure to numerous members of the general public. The individual requested a hearing on May 26, 1994, and a settlement agreement was signed November 13, 1995. The settlement reduces to three years the prohibition on the individual's involvement in NRC-licensed activities.

Paul A. Bauman IA 94-020

An Order Requiring Notification to NRC Prior to Involvement in NRCLicensed Activities (Effective Immediately) was issued August 26, 1994 to the above individual. The action was based on the failure to train and certify personnel, creation of false records, and providing false information to the NRC. The Order requires for a period of three years that the individual provide notice to the NRC of his acceptance of each employment offer in NRC-licensed activities.

Michael J. Berna IA 94-032

An Order Prohibiting Involvement in NRC-Licensed Activities (Effective Immediately) was issued November 15, 1994 to the above individual. The Order was based on inspection and investigation findings which concluded that the individual deliberately violated 10 CFR 30.10 by failing to perform field audits of radiographers, created false audit records, and requested others to create false records. The order removes the 
individual from NRC-licensed activities for a period of three years. In addition, the individual is to notify the NRC the first time that he engages in licensed activities following the prohibition period.

Jerome E. Bodian, M.D. IA 94-023

A Confirmatory Order Prohibiting Involvement in NRC-Licensed Activities (Effective Immediately) was issued September 8, 1994 to the above individual. The action was based on an inspection and investigation which concluded that the individual deliberately violated 10 CFR 35.53 by failing to measure the activity of radiopharmaceuticals prior to medical use and 10 CFR 30.10 by deliberately providing inaccurate information to the NRC. The order prohibits the individual from engaging in NRC-licensed activities for a period of five years. In addition, the individual shall provide notice to NRC the first time following the prohibition that he engages in NRC-licensed activities.

Eugene Bolton

IA 96-009

An Order Prohibiting Involvement in NRC-Licensed Activities (Effective Immediately) was issued February 23, 1996 to the above individual. The Order was based on an investigation which concluded that the above individual violated the fitness for duty requirements by submitting a surrogate urine sample and by admittedly submitting surrogate urine samples successfully on previous occasions. The order prohibits the individual from seeking unescorted access to facilities licensed by the NRC for a period of five years from March 9, 1993, the date that the individual's unescorted access was terminated by the licensee.

John W. Boomer IA 94-015

An Order Prohibiting Involvement in NRC-Licensed Activities (Effective Immediately) was issued July 14, 1994 to the above individual. The Order was based on investigation findings which concluded that the individual deliberately violated 10 CFR $35.70(\mathrm{e})$ and 10 CFR 30.10 while he was President of Chesapeake Imaging Center, Chesapeake, West Virginia, by failing to conduct weekly surveys for removable contamination. The order prohibits the individual from engaging in NRClicensed activities for a period of three years. In addition, for that same period he shall provide a copy of the Order to any prospective employer engaged in NRC-licensed activities, provide notice to NRC the first time following the prohibition that he engages in NRC-licensed activities, and cease activities if he is currently involved in NRClicensed activities.

Richard J. Gardecki IA 93-001

An Order Prohibiting Involvement in Certain NRC-Licensed Activities was issued May 4, 1993 to the above individual. The Order was based on the deliberate submittal of false information to former employers to obtain employment in licensed activities and to NRC investigators. The order prohibits the individual, for a period of five years, from being named on an NRC 1icense as a Radiation Safety Officer or supervising licensed 
activities for an NRC 1icensee or an Agreement State 1icensee while conducting activities within NRC jurisdiction. It also requires for the same period notice by copy of the Order to prospective employers engaged in licensed activities and notice to the NRC on acceptance of employment in Ticensed activities.

Juan Guzman

IA $96-020$

An Order Prohibiting Unescorted Access or Involvement in NRC-Licensed Activities (Effective Immediately) was issued April 19, 1996 to the above individual. The Order was based on an investigation which concluded that the individual falsified his background information to his employer, Baltimore Gas and Electric. The individual requested a hearing on April 29, 1996. A settlement order was signed 0ctober 4, 1996 and approved by the Licensing Board on October 16, 1996. The settlement stipulates that the individual agrees that from October 18 , 1994, the date of his termination of unescorted access, until october 17 , 1997, he is prohibited from seeking or obtaining unescorted access at any NRC-licensed facility and may not be involved in any NRC-1icensed activities. Also for a period of two years following the prohibition, should he seek employment with any person who operations involve any NRC-1icensed or regulated activity, he will provide a copy of the April 19, 1996 order and the agreement prior to employment.

Mark Jensen

IA $96-042$

An Order Prohibiting Involvement in NRC-Licensed Activities was issued July 16, 1996 to the above individual. The Order was based on a violation of 10 CFR 30.10, which caused his former employer to be in violation of NRC requirements by failing to utilize trained and qualified individuals for the conduct of radiographic operations. In addition, the individual attempted to generate a falsified training record for a radiographer. The Order prohibits the individual from engaging in NRC-licensed activities for a period of five years, and for a period of five years following the prohibition is required to notify the NRC when he engages in or exercises control over NRC-licensed activities.
William Kimbley
IA $95-016$
Ms. Joan Kimbley
IA $95-015$

A Confirmatory Order was issued June 12, 1995 based on an investigation which concluded that Midwest Testing, Inc., through its president, del iberately violated NRC requirements by: (1) allowing operators to use moisture density gauges without personnel monitoring devices, (2) not performing leak tests of two moisture density gauges, (3) not requesting a license amendment to name a new Radiation Protection Officer, (4) storing licensed material at an unauthorized location, and (5) allowing moisture density gauges to be used with an expired 1icense. The investigation al so concluded that the licensee's General

Manager/Treasurer (the wife of the licensee's president) was involved in the deliberate violations noted in items (1), (2), and (5) above. The Order prohibits both the president and the General Manager/Treasurer, as well as Midwest Testing, Inc. and any successor entity, from applying to 
the NRC for a license and from engaging in, or controlling, any NRClicensed activity for a period of five years.

Larry S. Ladner IA 94-019

An Order Prohibiting Involvement in NRC-Licensed Activities (Effective Immediate7y) was issued August 26, 1994 to the above individual. The action was based on the individual's failure to supervise radiographer's assistants performing licensed activities, falsifying a large number of quarterly personnel audits and providing false information to NRC officials. The Order prohibits the individual from engaging in NRClicensed activities for a period of three years and for a two year period after the prohibition has expired, requires him to provide notice to the NRC when he will be involved in NRC-licensed activities.

Donald C. McDonald, Jr.

IA $96-018$

An Order Prohibiting Involvement in NRC-Licensed Activities (Effective Immediately) was issued March 27, 1996 to the above individual. The action was based on the individual providing incomplete and inaccurate information on forms he filed for unescorted access authorization at an NRC-licensed facility. The Order prohibits the individual from engaging in NRC licensed activities, and obtaining unescorted access to protected and vital areas of facilities licensed by the NRC, for a period of three years from the date of the order.

Daniel J. McCool

IA $94-017$

An Order Prohibiting Involvement in NRC-Licensed Activities (Effective Immediately) was issued August 26, 1994 to the above individual. The action was based on an investigation which determined that the above individual deliberately conspired with other AMSPEC officials to deceive the Commission and provided false testimony, under oath, to NRC officials. In addition the individual failed to train and certify employees in radiation safety as required by the AMSPEC license. The Order prohibits the individual from engaging in NRC licensed activities for a period of five years, and for a period of five years after the prohibition to notify the NRC when he will be involved in NRC-licensed activities.

Stephen Mignotte IA 94-014

A Notice of Violation and Order Prohibiting Involvement in 10 CFR Part 55 Licensed Activities (Effective Immediately) was issued June 28, 1994 to the above individual. The actions are based on the individual performing licensed duties while under the influence of illegal drugs and submitting a false urine sample under the reactor licensee's fitness-for-duty program. The Order prohibits the individual from serving as licensed reactor operator for a period of three years from the date of the order, and for the same period of time, requires that he notify prospective employers involved in NRC-licensed activities of the existence of the Order. 
An Order Prohibiting Involvement in NRC-Licensed Activities (Effective Immediately) was issued April 21, 1994 to the above individual. The Order was based on an action taken by the individual during and following a rod mispositioning event at Dresden on September 18, 1992, while he was employed as the Qualified Nuclear Engineer at the Dresden Nuclear Station. The individual's actions included an attempt to conceal the occurrence of the event. The Order prohibits the individual for three years from the date of the Order from engaging in activities licensed by the NRC. After the three year prohibition the individual sha11 provide notice to the NRC of acceptance of any employment in NRClicensed activity for an additional two year period.

Richard E. Odegard IA 94-018

An Order Prohibiting Involvement in NRC-Licensed Activities (Effective Immediately) was issued August 26, 1994 to the above individual. The action was based on the individual providing false testimony to the NRC, and deliberately failing to train and certify employees in radiation safety as required by the license conditions. The Order prohibits the individual from engaging in NRC-licensed activities for a period of five years and after the prohibition has expired requires him to provide notice to the NRC of acceptance of any employment in NRC-licensed activity for an additional five year period.
Jesus Osorio
IA $96-043$

An Order Prohibiting Involvement in NRC-Licensed Activities was issued July 16, 1996 to the above individual. The Order was based on a violation of 10 CFR 30.10 , which caused his former employer to be in violation of NRC requirements by failing to utilize trained and qualified individuals for the conduct of radiographic operations, and providing to the NRC materially inaccurate and incomplete information relating to radiographers training. The order prohibits the individual from engaging in NRC-7icensed activities for a period of five years, and for a period of five years following the prohibition is required to notify the NRC when he engages in or exercises control over NRC-7icensed activities.

Hartsel1 S. Phillips

IA $94-001$

An Order Prohibiting Involvement in NRC-Licensed Activities (Effective Immediately) was issued March 10, 1994 to the above individual. The action was based on the individual's deliberate false statements to NRC officials and deliberate violations involving: (1) administration of excessive radiopharmaceutical dosages, (2) failure to provide training to nuclear medicine technologists, (3) failure to perform daily constancy checks of the licensee's dose calibrator, (4) failure to perform the required daily and weekly contamination radiation surveys, and (5) failure to maintain accurate and complete records required by NRC. The Order prohibits the individual from engaging in NRC-licensed activities for an NRC licensee or an Agreement State that is subject to NRC jurisdiction. The individual requested a Hearing on March 30, 1994. A settlement was signed September 19, 1995 with the agreement that the 
individual would refrain from involvement in NRC-licensed activities for a period of five years from the date of the order and, for a period of five years after the prohibition, will notify NRC of becoming involved in NRC-licensed activities.

Douglas D. Preston IA 94-004

An Order Prohibiting Involvement in NRC-Licensed Activities (Effective Immediately) was issued Apri1 5, 1994 to the above individual. The action was based on the individual's falsification of information on his application for unescorted access to the Ticensee's Duane Arnold Energy Center. When interviewed by the investigators, the individual admitted that he had falsified his criminal history and indicated he would do so again. The order prohibits the individual from involvement in licensed activities for a period of five years.

Guillermo Velasquez, M.D. IA 94-013

A Confirmatory Order was issued June 3, 1994 to the above individual. The action was based on the individual's deliberate use of a $\mathrm{Sr}-90$ eye applicator after his 1 icense had expired and providing false information to the NRC. The Order prohibits the individual's participation in licensed activities for a period of three years and requires the individual to notify the NRC the first time he engages in 1 icensed activities after the prohibition period has ended.

David Tang Wee

IA 94-006

An Order Prohibiting Involvement in NRC-Licensed Activities (Effective Immediately) was issued April 21, 1994 to the above individual. The Order was based on an action taken by the individual during and following a rod mispositioning event at Dresden on September 18, 1992, while he was employed as the Station Control Room Engineer at the Dresden Nuclear Station. The individual's actions included an attempt to conceal the occurrence of the event. The Order prohibits the individual for three years from the date of the Order from engaging in activities licensed by the NRC. After the three year prohibition the individual shall provide notice to the NRC of acceptance of any employment in NRC-licensed activity for an additional two year period.

Rex Allen Werts

IA $94-035$

An Order Prohibiting Involvement in NRC-Licensed Activities and Unescorted Access (Effective Immediately) was issued December 12, 1994 to the above individual. The action was based on an investigation that concluded that the above individual had deliberately falsified his identity to gain employment and unescorted access to the Brunswick facility. The Order prohibits the individual from engaging in NRClicensed activities and from gaining unescorted access to protected and vital areas of NRC-licensed facilities for a period of three years. After the three year prohibition the individual shall provide notice to the NRC of any employment in NRC-licensed activity for an additional five year period. 
Larry D. Wicks

IA 94-024

An Order Prohibiting Involvement in NRC-Licensed Activities (Effective Immediately) was issued September 27, 1994 to the above individual. The action was based on inspections and investigations which concluded that the individual deliberately violated NRC requirements as to submitting a dosimeter for evaluation, evaluating an employee's radiation exposure, providing calibrated ratemeters, and by providing false information to the NRC. The Order removed the individual from NRC-licensed activities for a period of five years. In addition, the order requires the individual to provide notice to the NR'C the first time following the prohibition that the individual engages in NRC-licensed activities. The individual requested a hearing on October 14, 1994. In a settlement approved on November 16, 1995, the individual agreed to withdraw from the hearing proceeding.

Marc W. Zuverink IA 95-022

An Order Prohibiting Involvement in NRC-Licensed Activities and Requiring Certain Notification to NRC was issued June 27, 1995 to the above individual. The action was based on an investigation which determined that the individual stole tritium from the licensee's facility and transferred it to members of the public. The Order prohibits the individual from engaging in NRC-licensed activities for a period of ten years and requires that he provide notice to NRC for an additional five year period if he becomes involved in NRC-licensed activities.

Notices of Violation

Robert C. Allen

IA $96-065$

A Notice of Violation was issued October 18, 1996 to a 1 icensed operator. The individual deliberately failed to comply with the provisions of his license, which included violating approved, detailed written procedures for the venting of the Unit 1 pressurizer relief tank. As a result of these actions, the NRC operator's license was terminated and the operator was required to participate in a performance remediation plan.

Steven R. Allent

IA $96-050$

A Notice of Violation was issued September 5, 1996. The individual, while working as a contractor laundry technician/decontaminator at Point Beach Nuclear Plant, engaged in deliberate misconduct by taping a radioactively contaminated particle to the underside of a table in the radiological laundry room.

Richard L. Balcom IA 95-042

A Notice of Violation was issued October 17, 1995. The individual, a manager above first-line supervision at Houston Lighting and Power Company's Nuclear Security Department, deliberately discriminated against two employees. Specifically, he recommended termination of the employment as a result of the employees engaging in protected 
activities. The protected activities included identifying safety concerns to the NRC. The individual's employer removed him from licensed activities after issues about possible discrimination arose.

Robert Beltran

IA 96-074

A Notice of Violation was issued November 21, 1996. The individual submitted false employment information, claiming employment with an employer for five years when in fact, he had never been employed by the firm.

William E. Breen

IA 96-049

A Notice of Violation was issued August 27, 1996. The individual tested positive under the 1 icensee's fitness-for-duty program resulting in a confirmed positive test of marijuana, and as a result Commonwealth Edison Company informed the NRC that the individual's operator license had expired on August 13, 1996 and there was no need for renewal.

Kirk H. Carroll

IA $96-051$

A Notice of Violation was issued September 6, 1996. The individua1, a mill foreman, entered the yellowcake packaging enclosure, placed a lid on a filled yellowcake drum and rolled the drum outside for final packaging without wearing a full face respirator, although he knew there was a plant procedural requirement to wear one.

Richard Fentiman

IA 96-061

A Notice of Violation was issued September 27, 1996. The individual intentionally instructed contract access authorization employees to use references listed by applicants for unescorted access as "developed" references, an instruction that he knew was in violation of Nebraska Public Power District's policy and procedures for conducting background investigations of applicants. The individual was disciplined by the licensee and voluntarily resigned in November 1995.

Gregory L. Goodchild

IA $96-072$

A Notice of Violation was issued November 14, 1996 to the above individual. The individual, a radiochemistry technician employed by Wisconsin Electric Company, 1) engaged in deliberate misconduct when he failed to perform a QA check of the Hewlett Packard gas chromatograph before the first analysis is performed each day, and 2) deliberately provided false information to the licensee by maintaining that he had performed the QA check after being confronted with evidence to the contrary. The individual's employment was terminated by the licensee.

Richard C. Gracin

IA $96-052$

A Notice of Violation was issued December 19, 1996. The individual, a security shift supervisor, provided false information to the licensee and the NRC regarding the timing of his actions to the number of escorts that were provided with a group of visitors inside the vital area. The individual's employment was terminated by the licensee. 
David A. Harris

IA $96-062$

A Notice of Violation was issued 0ctober 22, 1996, to the above individual. The individual, a contract security shift supervisor, submitted a urine sample with a significantly elevated temperature. The individual's employment with Burns International Security was terminated in November 1995 as a result of this incident.

Roger E. Jones

IA $96-073$

A Notice of Violation was issued November 19, 1996 to the above individual, based on a violation involving the confirmed positive test for marijuana.

Michael Muszynski

IA 96-067

A Notice of Violation was issued December 20, 1996 to the above individual, based on a violation involving the deliberate submittal of licensee information that he knew to be incomplete or inaccurate in some respect material to the NRC.

Kipp Rustenholtz

IA $96-040$

A Notice of Violation was issued July 17, 1996, based on the following deliberate violations: (1) receipt of NRC-licensed material at locations other than South Haven Community Hospital, (2) failure to measure dosages of technetium-99m prior to administering the material to patients, (3) creation of inaccurate records by recording calculated dosage activity in place of measured activity, and (4) falsely annotating a patient dosage record to indicate that a dosage measurement had been made, when in fact the measurement had not been made. 
A- ORDERS

NUREG-0940, PART I 


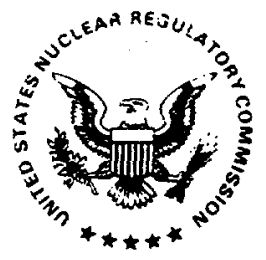

\section{UNITED STATES \\ NUCLEAR REGULATORY COMMISSION \\ WASHINGTON, D.C. 20555-0001}

December 1, 1995

IA $95-058$

Five Star Products, Inc.

Construction Products Research, Inc.

ATTN: Mr. H. Nash Babcock,

401-534 Stillison Road

Fairfield, Connecticut 06430

\section{SUBJECT: ORDER}

Dear Mr. Babcock:

This refers to the limited inspection conducted on August 18 and 19, 1992, of the Five Star Products, Incorporated (Five Star) facilities in Fairfield, Connecticut. A copy of the inspection report is included as Enclosure 1 to this letter. This letter also addresses the NRC Office of Investigations (OI) Case 1-92-037R, which has been completed. A copy of the OI Report synops is is included as Enclosure 2 to this letter.

Enclosure 3 is an Order being issued to Five Star, Construction Products Research, Inc. (CPR), and $H$. Nash Babcock based on the results of the inspection and investigation. The Order prohibits Five Star, CPR, or H. Nash Babcock from selling products or providing associated services to meet the requirements of 10 CFR Part 50 Appendix $B$ and 10 CFR Part 21 . Further, the Order provides that if Five Star, CPR or H. Nash Babcock desires to resume providing basic components and associated services to the nuclear industry that meet those requirements, then Five Star, CPR and H. Nash Babcock must comply with certain provisions of the Order.

A written response is not required to the order. However, you may respond as provided in the Order. If Five Star, CPR or H. Nash Babcock desires to resume providing basic components and associated services to the nuclear industry for use in safety-related applications, Five Star, CPR, and H. Nash Babcock must respond to the Order, as well as comply with the other requirements stated in the order.

This Order is effective in 20 days unless a hearing is requested.

Pursuant to Section 223 of the Atomic Energy Act of 1954, as amended, any person who willfully violates, attempts to violate, or conspires to violate, any provision of this Order once it is effective shall be subject to criminal prosecution as set forth in that section.

The NRC is continuing to review various actions by Five Star and CPR and issuance of this Order does not preclude the NRC from taking further action in the future based on the outcome of those reviews. 
Five Star Products, Inc.

Questions concerning this Order should be addressed to James Lieberman, Director, Office of Enforcement, who can be reached at (301) 415-2741.

In accordance with 10 CFR 2.790 of the NRC's "Rules of Practice," a copy of this letter and its enclosures will be placed in the NRC Public Document Room.

Sincerely,

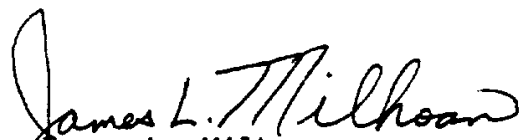

James L. Milhoan

Deputy Executive Director

for Nuclear Reactor Regulation,

Regional Operations and Research

Enclosures: As Stated 
UNITED STATES

NUCLEAR REGULATORY COMMISSION

In the Matter of

FIVE STAR PRODUCTS, INC. and CONSTRUCTION PRODUCTS RESEARCH Fairfield, Connecticut and

H. NASH BABCOCK

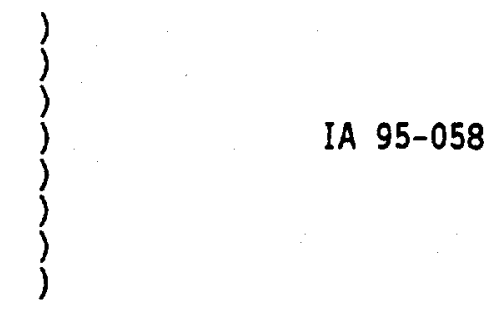

ORDER

I

Five Star Products, Inc. (FSP), is a company located in Fairfield, Connecticut, and was formerly known as U.S. Grout Corporation. FSP manufactures and sells grout and concrete products to the nuclear industry and has done so for about 20 years. Through a holding company, Mr. Babcock owns FSP and several related businesses, including Construction Products Research, Inc. (CPR), which performs laboratory tests of FSP products. Mr. Babcock is Vice-President of FSP and President of CPR.

[I

FSP submitted its grout and concrete products to CPR for testing. Following the tests, CPR issued certifications that it tested FSP products in conformance with certain specifications of the American Society for Testing and Materials. FSP subsequently utilized those certifications as the bas is for certifying that its products satisfied Appendix $B$ and customer Purchase Order (PO) requirements. At various times since 1980, FSP has advertised and represented to NRC licensees that its products are manufactured in accordance with the requirements of Appendix B. It has supplied products pursuant to purchase orders requiring FSP to meet the requirements of Appendix $B$, and 10 
CFR Part 21. Licensees who have purchased material from FSP under FSP's certification of quality have used the grout and concrete in safety-related applications and as basic components.

The Nuclear Regulatory Commission (NRC or Commission) issued 10 CFR Part 21 (Part 21) to implement Section 206 of the Energy Reorganization Act of 1974. Part 21 imposes, inter alia, evaluation and reporting requirements on directors and responsible officers of firms which supply basic components of any facility or activity which is licensed or otherwise regulated pursuant to the Atomic Energy Act of 1954, as amended, or the Energy Reorganization Act of 1974. Basic components are structures, systems, or parts in which a defect or failure to comply with applicable requirements could create a substantial safety hazard. 10 CFR $21 \cdot 3(a)$. Part 21 is implemented in conjunction with Appendix $B$, which contains the quality assurance $(Q A)$ criteria applicable to design, fabrication, construction, and testing of safety-related structures, systems, and components in commercial nuclear power plants. Together, these requirements are intended to assure the safety of safety-related components, materials, and services for nuclear power plants.

Section 206 of the Energy Reorganization Act of 1974 requires directors and responsible officers of firms constructing, owning, operating or supplying the basic components of a facility or activity licensed or regulated by the Atomic Energy Act of 1954, as amended, who obtain information regarding defects in those basic components, or fallures of basic components, or of the facility to comply with NRC requirements, to notify the NRC of those defects and failures to comply. Section 206(d) authorizes the Commission to conduct inspections 
and other enforcement activities necessary to insure compliance with that section. 10 CFR 21.41 and 21.51 implement Section 206(d).

II]

The NRC conducts inspections of vendors who supply safety-related components pursuant to Appendix $B$ and who supply basic components pursuant to Part 21. On August 18, 1992, the NRC began an unannounced inspection of FSP, and of its laboratory contractor, CPR, to determine the extent to which FSP supplied basic components to NRC licensees, the adequacy of FSP's QA Program, the adequacy of CPR's testing of FSP products, and the adequacy of FSP products:

Shortly after the inspection began, Mr. Babcock met with the inspection team and questioned the NRC's authority to conduct the inspection. Mr. Babcock was presented with two identical letters from the NRC staff, dated August 13, 1992, each addressed separately to FSP and CPR. The letters outlined the NRC's inspection authority under 10 CFR Part 21, Section 1610 of the Atomic Energy Act of 1954, as amended (AEA), and Section 206(d) of the Energy Reorganization Act of 1974, as amended (ERA). Despite this, Mr. Babcock continued to question the NRC's authority and, throughout the inspection, denied the inspectors access to inspect CPR's testing laboratory, which was located in the basement of FSP's Fairfield, Connecticut, headquarters, and access to inspect CPR's laboratory records.

During the inspection of August 18 and 19, 1992, the inspection team reviewed NRC power reactor licensee POs submitted to Five Star in order to determine 
the scope of FSP's nuclear involvement. The team was provided with POs for the period 1988 to 1992 . Those POs demonstrate that at least seven NRC reactor licensees and one licensee contractor had issued POs to FSP for safety-related grout and concrete mix products, and had specified compliance with Appendix $B$ and Part 21.

The inspection team reviewed copies of several NRC licensee audit reports of FSP and CPR. These reports documented that NRC 1 icensee requests to audit CPR's test laboratory and records were consistently denied by FSP. Further, several NRC 1 icensee audit reports found that FSP's QA program was not acceptable and did not meet certain requirements of Appendix $B$.

The NRC inspection team requested copies of all audits performed by FSP of CPR to determine CPR's compliance with the quality assurance criteria of Appendix $B$ and Part 21. Only one FSP audit of CPR was performed, by the FSP QA Manager, and it was provided to the NRC inspection team by the FSP QA Manager. The July 31, 1992 audit report concluded that CPR's June 10, 1992 QA program was satisfactory. The format and most of the language of this report were identical to a report of an audit conducted by Toledo Edison, an NRC Part 50 reactor 1icensee, of FSP's QA program in February 1991. The FSP QA Manager later admitted that he had not in fact conducted an audit of CPR, and that he had used the Toledo Edison audit report to fabricate the July 31, 1992 audit report of CPR.

On August 19, 1992, the second day of the inspection, Mr. Babcock told the inspectors to leave at the end of that day and not return until after Labor 
Day. At 4:45 p.m. that day, Mr. Babcock was presented with another letter from the NRC staff which was witnessed by members of the inspection team and Mr. Henry Allen of FSP. This letter reiterated the legal authority of the NRC to conduct the inspection, and notified Mr. Babcock that continued refusals to permit inspection of FSP or CPR would be treated as a violation of 10 CFR 21.41 , could result in enforcement action, and could be subject to treatment as a criminal violation in accordance with Sections 1610 and 223 of the AEA. Notwithstanding this second letter, Mr. Babcock continued to deny the NRC inspectors access to the CPR laboratory and to records of the CPR laboratory. The inspectors left the site at 5:00 pm as Mr. Babcock had requested.

The inspection team also requested copies of QA manuals for both FSP and CPR which would provide the basis to support FSP's certifications to licensees that its products were manufactured under an Appendix B Quality Assurance (QA) program. Copies of these documents were not furnished by FSP due to Mr. Babcock's suspension of further inspection activities.

As a result of FSP's and Mr. Babcock's curtailing the inspection, the inspection team was unable to review the implementation of FSP'S QA Program against licensee POS or to inspect CPR's testing of FSP's grout and concrete mix products, and thus was unable to determine whether those products were produced, tested and provided in compliance with Appendix $B$ and Part 21. Therefore, the NRC staff could not determine whether there was reasonable assurance that those FSP grout and concrete mix products were acceptable for use in safety-related applications in nuclear power plants. 
Shortly thereafter, the NRC obtained a federal criminal search warrant, which was executed on September 1, 1992. Certain documents and testimonial evidence were taken.

Additionally, the NRC Office of Investigations conducted an investigation of the allegations leading to and the events surrounding the inspection. 101 Case No. 1-92-037). During the course of the OI investigation, Mr. Babcock instructed his attorney to forward to the NRC a letter dated February 18, 1994, which Mr. Babcock had composed and signed. The attorney forwarded the letter, in which Mr. Babcock stated: "We did not deny the NRC inspectors access to the laboratory in August 1992. Mr. John S. Ma, a civil engineer on the NRC inspection team, was escorted to the lab where he conducted an inspection of the test laboratory." As indicated above, and as known to Mr. Babcock, no NRC inspectors were allowed in the laboratory at any time during the August 1992 inspection and, therefore, the statement concerning $M r$. Ma's access to and inspection of the CPR laboratory is deliberately false. The letter was material because it provided incorrect information to the NRC on a matter that was under investigation.

Based on the facts discussed above, the NRC concludes that the following violations of NRC requirements occurred:

A. 10 CFR 50.5, "Deliberate misconduct" prohibits any contractor (including a supplier or consultant), subcontractor, or any employee of a 
contractor or subcontractor who knowingly provides to any licensee, contractor, or subcontractor, components, equipment, materials, or other goods or services, that relate to a licensee's activities subject to this part, from deliberately submitting to the NRC, a licensee, or a licensee's contractor or subcontractor, information that the person submitting the information knows to be incomplete or inaccurate in some respect material to the NRC.

Contrary to the above, the Quality Assurance Manager of Five Star Products, and Five Star Products through its Quality Assurance Manager, prepared an audit report for Five Star Products of the Construction Products Research QA Program, dated July 31, 1992, without conducting an audit of Construction Products Research, and provided that audit report to NRC inspectors during an inspection of Five Star Products on August 18-19, 1992, knowing that no such audit had been conducted. This audit report was material to the NRC because it was capable of influencing its determination of whether the Construction Products Research QA Program complied with Appendix B, and 10 CFR Part 21 requirements.

B. Contrary to 10 CFR 50.5, Mr. H. Nash Babcock, the Vice President of Five Star Products, Inc. and the President of Construction Products Research, prepared and caused to be sent to the NRC a letter, in which Mr. Babcock stated that one NRC inspector had been allowed to and did in fact inspect the laboratory test facility of Construction Products Research on August 19, 1992. In fact, as Mr. Babcock knew, no NRC inspector was 
permitted to inspect the laboratory facilities of Construction Products Research during the August 18-19, 1992 inspection. The letter was material to the NRC because it provided information directly related to a matter under investigation by the NRC, specifically, whether $\mathrm{Mr}$. Babcock had deliberately denied NRC inspectors access to the Construction Products Research test facility in violation of NRC requirements.

C. 10 CFR 21.41 requires that each individual, corporation, partnership or other entity subject to the regulations in Part 21 shall permit duly authorized representatives of the Commission to inspect its records, premises, activities, and basic components as necessary to effectuate the purposes of Part 21 .

10 CFR $21.51(b)$ requires, in part, that each individual, corporation, partnership or other entity subject to the regulations in Part 21 must afford the Commission, at all reasonable times, the opportunity to inspect records pertaining to basic components.

Contrary to the above, on August 18 and 19, 1992, Five Star Products, Inc., through H. Nash Babcock, Vice President of Five Star Products, and Construction Products Research, Inc., through H. Nash Babcock, President of Construction Products Research, denied NRC inspectors access necessary to conduct an inspection of Five Star Products' contracted laboratory test facility, Construction Products Research, for, and of Construction Products Research records of test data associated with, 
safety-related grout and concrete mix products sold by Five Star

Products to nuclear power plants licensed under 10 CFR Part 50, pursuant to purchase orders specifying compliance with Appendix B and 10 CFR Part 21. Mr. Babcock also refused to allow NRC inspectors reasonable access to CPR laboratory personnel. By terminating the inspection, Mr. Babcock al so prevented NRC inspectors from completing their examination of Five Star records.

The NRC and its licensees must be able to rely on licensee contractors and". officers of licensee contractors, including providers of safety-related basic components such as Five Star Products, Inc., and suppliers of services associated with basic components, such as Construction Products Research, Inc., to comply with NRC requirements, including the requirements to provide accurate and complete information in all material respects and the requirements to permit inspection of their records, premises, activities and components. Five Star Products' and Mr. H. Nash Babcock's violations of 10 CFR 21.41, 21.51(b), and 50.5 demonstrate that Five Star Products and its Vice President, Mr. Babcock, are unable or unwilling to comply with NRC requirements to permit inspections and to provide complete and accurate information to the NRC in all material respects. In addition, they did not permit NRC 1icensees access to CPR's facilities in order to conduct necessary audits. Construction Products Research's and Mr. Babcock's violation of 10 CFR 21.41, 21.51(b), and 50.5 demonstrate that Construction Products Research and its President, Mr. Babcock, are unable or unwilling to comply with NRC 
requirements to permit inspections by the NRC or its licensees and to provide complete and accurate information to the NRC in all material respects. Consequently, I lack the requisite reasonable assurance that the NRC and NRC licensees can rely on the statements or certifications of Five Star Products, Inc., Construction Products Research, Inc., or Mr. H. Nash Babcock, that basic components of Five Star Products. Inc. or associated services of Construction Products Research, Inc. meet NRC requirements necessary to protect public health and safety. Therefore, I find that the public health, safety, and interest require that Five Star Products, Inc., Construction Products Research, Inc. and Mr. Babcock (1) be prohibited from providing structures, systems, and components subject to a procurement contract specifying compliance with Appendix B, or basic components subject to a procurement contract specifying compliance with 10 CFR Part 21 , and (2) must respond to this Order and take certain other actions if they desire to provide such products to NRC licensees who specify that they must meet the requirements of Appendix B, or 10 CFR Part $21^{1}$.

Accordingly, pursuant to Sections 103, 161b, 161i,1610,182, and 186 of the Atomic Energy Act of 1954, as amended, Section 206 of the Energy

${ }^{1} T h i s$ does not prohibit FSP from supplying commercial grade materials to NRC 1 icensees, or CPR from testing and certifying commercial grade materials to NRC licensees, provided that no representations are made with regard to FSP products being qualified for safety-related applications in nuclear power plants based on compliance with 10 CFR Part 50, Appendix B, or that 10 CFR Part 21 requirements have been met. 
Reorganization Act, as amended, and the Commission's regulations at 10 CFR 2.202, 10 CFR Parts 21 and 50, and 10 CFR 50.5, IT IS HEREBY ORDERED, THAT:

1. Until Five Star Products, Inc., Construction Products Research, Inc., $H$. Nash Babcock, and any concern which is owned, controlled, operated or managed by $H$. Nash Babcock, satisfy the provisions of paragraph 2., below, they are prohibited from:

A. providing or supplying structures, systems, or components, including grout and concrete, subject to a procurement contract specifying compliance with Appendix B; and B. providing or supplying basic components, including grout and concrete, subject to a procurement contract specifying that the contract is subject to the requirements of 10 CFR Part 21 ;

2.A. If Five Star Products, Inc., Construction Products Research Inc., or any concern owned, controlled, operated or managed by H. Nash Babcock, desires to lift the prohibition specified in paragraph 1, above, then Five Star Products, Inc., Construction Products Research, Inc., H. Nash Babcock or the concern owned, controlled, operated, or managed by $H$. Nash Babcock, sha11, at least 90 days prior to the date it desires to have the prohibition lifted:

(1) Advise the NRC of that intent in writing;

(2) Respond in writing under oath or affirmation specifically as to each of the violations listed in Section IV, including: (a) an admission or denial of the alleged violation, (b) the reasons for the violation if admitted, and if denied, the reasons why, (c) the 
corrective steps that have been taken and the results achieved, (d) the corrective steps that will be taken to avoid further violations, and (e) the date when full compliance will be achieved; (3) Agree in writing, under oath or affirmation, and in fact, to permit the NRC, NRC 1 icensees, and contractors performing QA functions for such licensees, to inspect the records, premises, basic components and activities of Five Star Products, Inc., of Construction Products Research, Inc., or of any concern owned, controlled, operated or managed by $H$. Nash Babcock that desires to provide safety related products or basic components, or to perform tests to support claims that those products or components and those testing services meet the standards of Appendix B and 10 CFR Part 21, and to signify in writing a willingness to do so in the future; (4) Agree in writing under oath or affirmation to demonstrate and in fact to demonstrate that those basic components and services associated with basic components meet the standards of Appendix $B$ by having tests performed by an independent third party and having that third party provide copies of the results of those tests directly to the NRC; and

(5) The officers, managers, and supervisors of Five Star Products, Inc. and Construction Products Research, Inc. provide statements 
that they understand that the activities and records of the organization are subject to NRC inspection, that communications with the NRC must be complete and accurate, and that any employee may provide information to the NRC at any time without fear of retribution; and

B. When all conditions of paragraph 2.A. above have been satisfied, and the NRC has conducted inspections of the QA program and Part 21 program of Five Star Products, Inc., Constructions Products Research, Inc., and any concern owned, controlled, operated, or managed by $H$. Nash Babcock, and any necessary corrective action has been completed, the prohibition of paragraph 1, above, will be lifted in writing.

The Director, Office of Enforcement, may, in writing, relax or rescind any of the above conditions upon demonstration by Five Star Products, Inc., Construction Products Research, Inc., and Mr. H. Nash Babcock of good cause.

In accordance with 10 CFR 2.202, Five Star Products, Inc., Construction Products Research, Inc., and H. Nash Babcock, or any other person adversejy affected by the Order, may submit an answer to this order, and may request a hearing on this Order, within 20 days of the date of this Order. The answer 
may consent to this Order. Unless the answer consents to this Order, the answer shall, in writing and under oath or affirmation, specifically admit or deny each allegation or charge made in this Order and shall set forth the matters of fact and law on which Five Star Products, Inc., Construction Products Research, Inc., and H. Nash Babcock, and any other person adversely affected relies and the reasons as to why the order should not have been issued. Any answer or request for a hearing shall be submitted to the Secretary, U.S. Nuclear Regulatory Commission, Attn: Chief, Docketing and Service Section, Washington, DC 20555. Copies also shall be sent to the Director, Office of Enforcement, U.S. Nuclear Regulatory Commission, Washington DC 20555, to the Assistant General Counsel for Hearings and Enforcement and the Director, Office of Nuclear Reactor Regulation, both at the same address. If a person other than Five Star Products, Inc., Construction Products Research, Inc., or $\mathrm{H}$. Nash Babcock requests a hearing, that person shall set forth with particularity the manner in which his or her interest is adversely affected by this order and shall address the criteria set forth in 10 CFR 2.714(d).

If a hearing is requested by Five Star Products, Inc., Construction Products Research, Inc., H. Nash Babcock, or any other person whose interest is adversely affected, the Commission will issue an Order designating the time and place of any hearing. If a hearing is held, the issue to be considered at such hearing shall be whether this Order should be sustained. 
In the absence of any request for hearing, the provisions specified in Section VI above shall be effective and final 20 days from the date of this Order without further order or proceedings.

FOR THE NUCLEAR REGULATORY COMMISSION

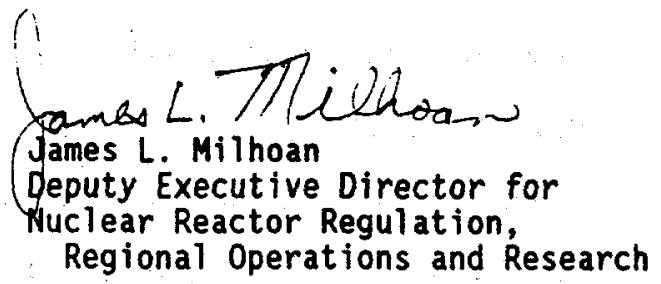

Dated at Rockville, Maryland

this ISt day of December 1995 
On September 30, 1992, an investigation was initiated concerning an allegation that Five Star Products. Inc. (Five Star), improperly tested and falsely certified material that was purchased from them by the nuclear power industry. During an unannounced August 18 and 19. 1992. inspection conducted by the NRC Vendor Inspection Branch (VIB), the NRC inspectors were denied access to Five Star's certification testing laboratory (i.e.. Construction Products Research (CPR)). Also, during the course of the inspection, a potentially fal se audit report was provided to the inspectors for their review. This audit report of CPR was produced by Five Star's Qual ity Assurance (QA) Manager. On September 1. 1992. as a result of the denial of access. a Federal search warrant was obtained and executed on Five Star. with documents and other physical and testimonial evidence taken.

The OI investigation concludes that Five Star provided three inaccurate product certifications to nuclear power plants, in that Five Star's laboratory (CPR) did not possess the proper equipment to perform a specific test referenced on the certifications. However, from the evidence developed. it has not been substantiated that the creation of the inaccurate certifications was deliberate.

The OI investigation also concludes that the President of CPR willfully denied the NRC inspectors access to the testing laboratory.

The OI investigation further concludes that the Five Star QA Manager deliberately generated an audit report of CPR, without conducting the audit. and provided this report to the inspectors during the inspection.

In addition. during the course of the investigation, the president of CPR caused a letter to be sent the NRC, in which he stated that one of the NRC inspectors had been allowed to inspect the laboratory. That information is refuted by the inspectors. It is therefore concluded that the letter was submitted, knowingly containing false information. 
Michael F. McBride, Esq.

LeBoeuf, Lamb, Greene \& MacRae

1875 Connecticut Avenue, N.W.

Washington, D.C. 20009-5728

SUBJECT: ORDER - IA 95-058 FIVE STAR PRODUCT, INC., CONSTRUCTION PROOUCTS RESEARCH, INC., AND H. NASH BABCOCK

Dear Mr. McBride:

I have received your letters of December 27, 1995, in regard to the Stipulation to resolve the matter and also Mr. William N. Babcock's position regarding a hearing. I have executed the Stipulation and a signed copy is enclosed along with a letter concerning Mr. William N. Babcock. I will forward the Stipulation to the Federal Register.

I appreciate your cooperation in this matter.

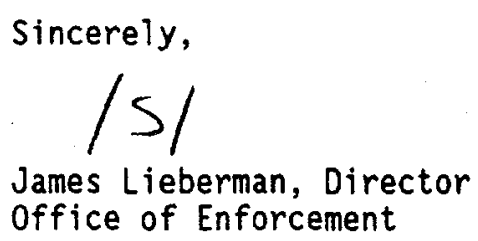

Enclosure: As Stated

cc: J. Goldberg, OGC SECY 
UNITED STATES OF AMERICA

NUCLEAR REGULATORY COMMISSION

In the Matter of

EIVE STAR PRODUCTS, INC. and

CONSTRUCTION PRODUCTS RESEARCH

Fairfield, Connecticut and

H. NASH BABCOCK

No. IA $95-058$

\section{STIPULATION BETWEEN NUCLEAR REGULATORY COMISSION AND FIVE STAR PRODUCTS, INC., CONSTRUCTION PRODUCTS RESEARCH, INC., AND H. NASH BABCOCK}

Representatives of the Nuclear Regulatory Commission

("NRC") and Five Star Products, Inc., Construction Products

Research, Inc. ("the Companies"), and $\mathrm{H}$. Nash Babcock have met and have decided to resolve this matter as addressed in this stipulation as set out below.

\section{STIPOLATION}

The NRC, the Companies, and H. Nash Babcock stipulate to the following:

1. The Companies and $H$. Nash Babcock are free to sell commercial-grade products to anyone in the nuclear industry, as they now do. "Commercial-grade" is defined as in 10 C.F.R. Part 21 of the Commission's regulations. Five Star Products' commercial-grade materials may be used in any safety-related applications provided that NRC licensees properly dedicate the materials for use as basic components and verify their suitability for the applications. As of the date of the 
settlement, NRC has not evaluated the quality of Five star Products' materials, nor has the NRC received reports that Five Star Products' materials contain defects.

2. The NRC hereby relaxes and modifies paragraphs 1 and 2 of section VI of the order as follows:

"1. Until the Companies or H. Nash Babcock or any concern which is owned, controlled, operated or managed by $H$. Nash Babcock, satisfy the provisions of paragraph 2 below, they are prohibited from:

A. providing or supplying structures, systems, or components, including grout and concrete, subject to a procurement contract specifying compliance with 10 C.F.R. Part 50 Appendix $B ;$ and B. providing or supplying basic components, including grout and concrete, subject to a procurement contract specifying that the contract is subject to the requirements of 10 CFR Part 21; 2.A. If the Companies, or any concern owned, controlled, operated or managed by H. Nash Babcock, desire to lift the prohibitions specified in paragraphs $1 . A$ and $1 . B$, above, then the Companies, H. Nash Babcock, or the concern owned, controlled, operated, or managed by $\mathrm{H}$. Nash Babcock, shall, at least 90 days prior to the date it desires to have the prohibition lifted:

(1) Advise the NRC of that intent in writing;

(2) Deleted. 
(3) Agree in writing, under oath or affirmation, and in fact, to permit the NRC, NRC licensees, and contractors performing QA functions for such licensees, to inspect the records, premises, basic components and activities of the Companies or of any concern owned, controlled, operated or managed by $H$. Nash Babcock that desires to provide safety-related products or basic components, or to perform tests to support claims that those products or components and those testing services meet the standards of 10 CFR Part 50 Appendix $B$ and 10 CFR Part 21, and to signify in writing a willingness to do so in the future;

(4) Agree in writing under oath or affirmation to demonstrate and in fact to demonstrate that those basic components and services associated with basic components meet the standards of 10 CFR Part 50 Appendix $B$ by having tests performed by a mutually acceptable third party and having that third party provide copies of the results of those tests directly to the NRC; and

(5) The officers, managers, and supervisors of the Companies provide statements that they understand that the activities and records of the organization are subject to NRC inspection and that communications with the NRC must be complete and accurate;

B. When all conditions of paragraph 2. A above have been satisfied, and the NRC has conducted inspections of the $Q A$ program and Part 21 program of the Companies or of any concern owned, controlled, operated, or managed by H. Nash Babcock, and 
any necessary corrective action has been completed, the prohibitions of paragraphs $1 . A$ and $1 . B$, above, will be lifted in writing."

3. Except for the enforcement action reflected in the above-relaxed order and this stipulation, the NRC will neither impose, nor seek to impose, any sanction lother than as set forth in the relaxed order and stipulation) on the Companies or their officers and employees or $\mathrm{H}$. Nash Babcock for the alleged violations described in the NRC Order issued on December 1, 1995.

4. All matters involving the termination of employment of Mr. Edward P. Holub are not covered by, or affected by, this Stipulation, the stipulation is without prejudice to the parties' positions with respect to the Commission's jurisdiction or lack thereof over employment matters, and the NRC, the Companies, any other related company, and $\mathrm{H}$. Nash Babcock retain all rights in any such case, matter, proceeding, or litigation now pending or which may hereinafter be instituted.

5. In light of this stipulation, the Companies and $H$. Nash Babcock agree not to request a hearing on the matters addressed in the Order issued on December 1, 1995 and relaxed as described herein, despite their vigorous disagreement with some of the allegations contained in the December 1, 1995 order.

6. The NRC, the Companies, and H. Nash Babcock agree that the allegations in the order have not been made subject to an evidentiary hearing, and that this stipulation will obviate the necessity for such a hearing, and they therefore agree that those allegations shall not estop any party from taking a 
different position on such matters in any other case, litigation, matter, or proceeding.

7. The order as relaxed herein shall be effective upon execution of this stipulation. This stipulation shall be published in the Federal Register.

8. The persons signing below certify by their signatures that they have authority to sign this stipulation for the entities appearing below their names.

\section{$\frac{\text { Anex Luben }}{\text { James Lieberman }}$ \\ oprector \\ Office of Enforcement \\ U.S. Nuclear Regulatory Commission \\ washington, D.C. 20555-0001 \\ (301) 415-2741 \\ For the United States Nuclear Requlatory Commission}

Dated: December 28, 1995

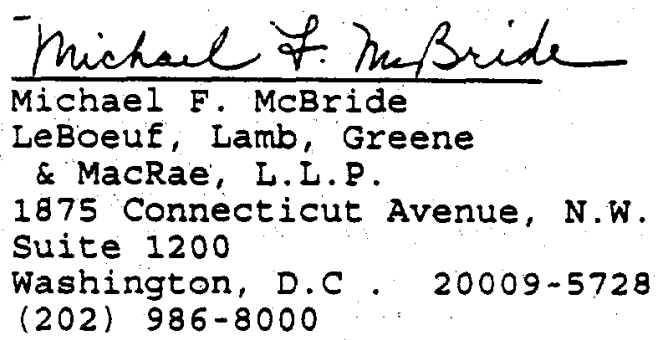

Attorney for Five Star products. Inc., Construction Products Research, Inc., and $H$. Nash Babcock 


\section{UNITED STATES \\ NUCLEAR REGULATORY COMMISSION \\ WASHINGTON, D.C. 20565-0001}

\section{$\operatorname{mir} 101984$}

IA $94-011$

Dr. James Bauer, Medical Director

Indiana Regional Cancer Center

877 Hospital Road

Indiana, Pennsylvania 15701

Dear Dr. Bauer:

Subject: order Prohibiting Involvement in NRC Licensed Activities (Effective Immediately)

The enclosed order is being issued to you based on the findings of an NRC inspection conducted on November 11, 1993, at the Indiana Regional Cancer Center (IRCC) facility in Indiana, Pennoylvania, and specifically: (1) your performance, as the Radiation safety officer and only authorized user, of activities with a strontium-90 source that were not authorized by NRC Ilcense No. 37-28179-01, (2) your deliberate failure to provide complete and accurate information to NRC inspectors on November 11, 1993, and (3) your failure to cause a survey to be performed as required by 10 CFR 20.201 at the Indiana Regional Cancer Center in a November 16, 1992, event which resulted in a significant radiation exposure to a patient and unnecessary radiation exposure to numerous members of the public.

Should you have any questions on this matter, please contact Ms. Patricia Santiago at (301) 504-3055.

In accordance with 10 CFR 2.790 of the NRC's "Rules of Practice", a copy of this letter and the enclosures will be placed in the NRC's Public Document Room.

Enclosure:

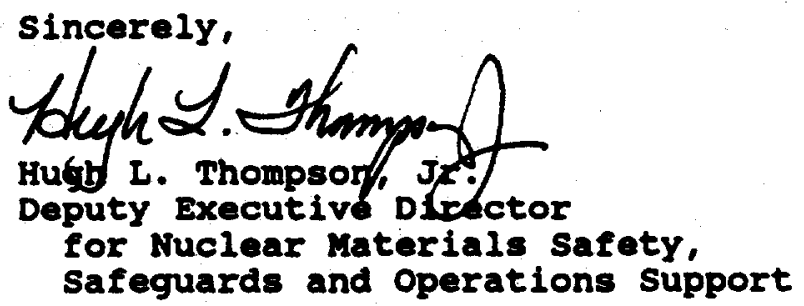

As Stated 
cc w/encl:

Public Document Room (PDR)

Nuclear Safety Information Center (NSIC)

Commonwealth of Pennsylvania

Indiana Hospital

Miners Hospital

Douglas R. Colkitt, M.D.

President, Oncology Services Corporation

2171 Sandy Drive

State College, Pennsylvania 16801 
UNITED STATES

NUCLEAR REGULATORY COMMISSION

In the Matter of

James Bauer, M.D.

\{

IA $94-011$

ORDER PROHIBITING INVOLVEMENT IN

NRC-LICENSED ACTIVITIES

(EFFECTIVE IMMEDIATELY)

I

Dr. James Bauer, M.D. (Dr. Bauer) is listed as the Radiation Safety officer (RSO) and sole authorized user on NRC License No. 37-2817901 (1icense) issued to the Indiana Regional Cancer Center (Licensee) located in Indiana, Pennsylvania. Byproduct License No. 37-28179-01 was issued by the Nuclear Regulatory Commission (NRC or Commission) pursuant to 10 CFR Parts 30 and 35, and authorizes the Licensee to use a strontium-90 source for the treatment of superficial eye conditions in accordance with the conditions specified therein. The license, originally issued on April 25, 1988, was due to expire on April 30, 1993, but remained in effect, pursuant to $10 \mathrm{CFR} 30.37$ (b), based on a timely request for renewal that was received by the NRC on April 5, 1993. By an order Modifying and Suspending License (Effective Immediately), issued November 16, 1993, the license was modified to prohibit Dr. Bauer from engaging in activities under the license and to suspend the Iicensee's authority to receive and use licensed material. 
On November 11, 1993, the NRC performed an inspection at the Licensee's facility in Indiana, Pennsylvania. During the inspection, the NRC found that Dr. Bauer had used the Iicensee's strontium-90 source to perform treatments of two patients for skin lesions on several occasions between September and November 1993, even though the license does not authorize the use of the strontium-90 for any purpose other than the treatment of superficial eye conditions. Since the use of the strontium-90 source for treatment of skin lesions not involving the eye is not authorized by the license, a violation of the license occurred.:

Prior to identifying that violation during the inspection, the inspectors asked $\mathrm{Dr}$. Bauer, as the Radiation safety officer and only authorized user listed on the license, about the treatment modalities for which the strontium-90 source was used. Dr. Bauer stated that the source had been used for the treatment of pterygium, an eye condition. When the inspectors asked Dr. Bauer whether the source had ever been used for any other modality, he again replied that the source had been used to treat pterygium.

The inspectors then requested records of the last six patients who received treatment with the strontium-90 source. The records provided to the inspectors reflected, only eye treatments. subsequently, the inspectors performed a review of the patient 
treatment log maintained by Dr. Bauer's secretary, as well as a review of records of additional patient treatments. The inspectors learned that the records initially provided were not for the last six patients treated, and that the records of the last six patient treatments included treatments for superficial lesions of the skin using the strontium-90 source, including a treatment that occurred on the day of the inspection before the inspection took place.

Dr. Bauer's failure to inform the inspectors that he had used the strontium-90 source to treat lesions of the skin, when specifically asked if the source was used for any purpose other than superficial eye treatments, caused the Indiana Regional Cancer Center to violate the requirements of $10 \mathrm{CFR} 30.9$, in that Dr. Bauer failed to provide information that was complete and accurate in all material respects to the NRC. In addition, in view of Bauer's use of the strontium-90 source for treatment of skin lesions prior to and on the day of the inspection, Dr. Bauer's communications to the inspector also constitute a violation of $10 \mathrm{CFR} 30.10$, in that Dr. Bauer deliberately provided to the NRC information that he knew to be incomplete or inaccurate in some material respect.

Previously, Dr. Bauer was involved in an incident in November 1992 at the Indiana Regional Cancer Center, as an authorized user and the supervisor of a treatment with a High Dose Rate Remote Afterloader (under Byproduct Materials License No. 37-28540-01 issued to oncology services corporation), that resulted in a 
patient being exposed to signiflcant levels of radiation, and numerous other members of the public being exposed to unnecessary radiation. Dr. Bauer had failed to cause a survey to be performed which was required by 10 CFR 20.201 and which could have prevented the exposures.

Based on the above, the NRC issued a Demand for Information (Demand) to Dr. Bauer on November 16, 1993. The Demand required Dr. Bauer to state: (1) why the NRC should not issue an order prohibiting Dr. Bauer's involvement in all NRC licensed activities; and (2) if such an order should not be issued, why the NRC should have confidence that Dr. Bauer would comply with all commission requirements. The Demand also required Dr. Bauer to state each institution and location at which Dr. Bauer engages in licensed activities.

In a letter dated January 5, 1994, Dr. Bauer, through his counsel, responded to the Demand for Information. The response stated that Dr. Bauer was a highly competent board certified radiation oncologist and radiologist with in excess of thirty years of experience in the safe use of radioactive materials; listed a number of areas where the licensee was found to be in compliance with NRC requirements and noted that there were no radiation safety violations, no harm to any individuals, and no risk to the public health and safety; stated that Dr. Bauer believed he was permitted to use the strontium-90 source for superficial skin lesion 
treatments; stated that Dr. Bauer fully and truthfully responded to all questions, and provided all requested information to the inspectors during the November 11, 1993 inspection; noted that the NRC had not attempted to levy any civil penalty for Dr. Bauer's alleged "failure to do an adequate survey in November 1992", and stated that the NRC has admitted that Dr. Bauer did not violate any license condition in November 1992 by allegedly failing to do an adequate survey; noted that the licensee's past performance has been exemplary; stated that there is no basis for the NRC to believe that Dr. Bauer will not comply with all Commission requirements, noting that he has in the past and will at all times in the future continue to use his best efforts to fully comply with all Commission requirements; stated that there has never been any finding that Dr. Bauer willfully or negligently violated any federal regulations or that he improperly uses radioactive material; and argued that to bar Dr. Bauer from any future licensed activities would constitute a travesty of justice to Dr. Bauer, the patients who rely on him, and society in general.

\section{III}

Based on the above, and after giving due consideration to his response to the Demand for Information, it appears that Dr. Bauer has engaged in deliberate misconduct that has caused the Licensee to be in violation of 10 CFR 30.9 ; deliberately provided to NRC inspectors information that he knew to be incomplete or inaccurate 
in some respect material to the NRC, in violation of 10 CFR 30.10 ; and failed to conduct a required survey on November 16, 1992, which resulted in unnecessary radiation exposure, to members of the public and a significant misadministration. The NRC must be able to rely on the Licensee and its employees, especially its authorized users and Radiation Safety officer, to comply with all NRC requirements, including the requirement to provide information to the NRC that is complete and accurate in all material respects. Dr. Bauer's action in causing the Indiana Regional Cancer Center to violate 10 CFR 30.9 and his violation of 10 CFR 30.10 through deliberate misrepresentations to the NRC, as well as his failure to perform the required survey noted above, have raised serlous doubt as to whether he can be relied upon to comply with NRC requirements and to provide complete and accurate information to the NRC.

Dr. Bauer is the sole authorized user and the Radiation safety Officer on NRC License No. 37-28179. As such, Dr. Bauer is required to know the requirements of the License and adhere to them. Dr. Bauer is not permitted to select those requirements that he will follow.

Consequently, I lack the requisite reasonable assurance that licensed activities can be conducted in compliance with the Commission's requirements and that the health and safety of the public will be protected, if Dr. Bauer were permitted at this time to be named in any capacity on an NRC license or were permitted to 
otherwise perform licensed activities. Therefore, the public health, safety and interest require that Dr. Bauer be prohibited from being named on an NRC license in any capacity and from otherwise performing licensed activities for a period of five years from the date of this order. For an additional two years, the public health, safety, and interest require that Dr. Bauer be required to notify the NRC of any involvement in licensed activities to assure that the NRC can monitor the status of Dr. Bauer's compliance with the Commission's regulatory requirements. Furthermore, pursuant to $10 \mathrm{CFR} 2.202$, I find that the significance of the violations and Dr. Bauer's conduct described above is such that the public health, safety and interest require that this order be immediately effective.

\section{IV}

Accordingly, pursuant to sections $81,161 \mathrm{~b}, 161 \mathrm{i}, 182$ and 186 of the Atomic Energy Act of 1954, as amended, and the Commission's regulations in 10 CFR 2.202 and 10 CFR 30.10, IT IS HEREBY ORDERED, EFFECTIVE IMMEDIATELY, THAT:

A. Dr. James Bauer, M.D., is prohibited for five (5) years from the date of this order from being named on an NRC license in any capacity or from otherwise performing NRClicensed activities. 
B. For an additional two year period following the five year prohibition in Paragraph IV.A. above, Dr. Bauer shall, within 20 days of his acceptance of an employment offer involving NRC-licensed activities or becoming involved in NRC-licensed activities, provide notice to the Director, office of Enforcement, U.S. Nuclear Regulatory Commission, Washingtón, D.C. 20555, of the name, address, and telephone number of the employer or the licensed entity where the licensed activities are or will be conducted.

The Director, office of Enforcement, may, in writing, relax or rescind any of the above conditions upon demonstration by Dr. Bauer of good cause.

In accordance with 10 CFR 2.202, Dr. Bauer must, and any other person adversely affected by this order may, submit an answer to this order, and may request a hearing on this order, within 20 days of the date of this order. The answer may consent to this order. Unless the answer consents to this order, the answer shall, in writing and under oath or affirmation, specifically admit or deny each allegation or charge made in this order and shall set forth the matters of fact and law on which Dr. Bauer or other person adversely affected relies and the reasons as to why the order should not have been issued. Any answer or request for a hearing 
shall be submitted to the Secretary, U.S. Nuclear Regulatory Commission, Attn: Chief, Docketing and Service Section, Washington, DC 20555. Copies also shall be sent to the Director, office of Enforcement, U.S. Nuclear Regulatory Commission, Washington, DC 20555, to the Assistant General Counsel for Hearings and Enforcement at the same address, to the Regional Administrator, NRC Region I, 475 Allendale Road, King of Prussia, PA 19406 and to Dr. Bauer if the answer or hearing request is by a person other than Dr. Bauer. If a person other than Dr. Bauer requests a hearing, that person shall set forth with particularity the manner in which his or her interest is adversely affected by this order and shall address the criteria set forth in 10 CFR 2.714 (d).

If a hearing is requested by $D r$. Bauer or a person whose interest is adversely affected, the commission will issue an order designating the time and place of any hearing. If a hearing is held, the issue to be considered at such hearing shall be whether this order should be sustained.

Pursuant to 10 CFR 2.202 (C)(2)(i), Dr. Bauer, or any other person adversely affected by this order, may, in addition to demanding a hearing, at the time the answer is filed or sooner, move the presiding officer to set aside the immediate effectiveness of the order on the ground that the order, including the need for immediate effectiveness, is not based on adequate evidence but on mere suspicion, unfounded allegations, or error. 
In the absence of any request for hearing, the provisions specified in section IV above shall be final 20 days from the date of this order without further order or proceedings. AN ANSWER OR A REQUEST FOR HEARING SHALL NOT STAY THE IMMEDIATE EFFECTIVENESS OF THIS ORDER .

FOR THE NUCLEAR REGULATORY COMMISSION

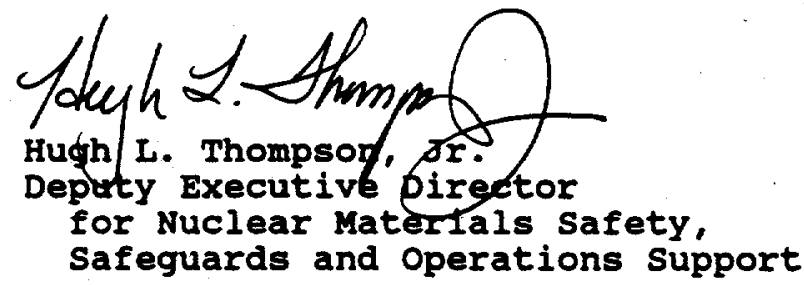

Dated at Rockville, Maryland this $10^{\text {th }}$ day of May 1994 
UNITED STATES OF AMERICA NUCLEAR REGULATORY COMMISSION

\section{ATOMIC SAFETY AND LICENSING BOARD}

Before Administrative Judges:

G. Paul Bollwerk, III, Chairman

Dr. Charles N. Kelber

Dr. Peter s. Iam

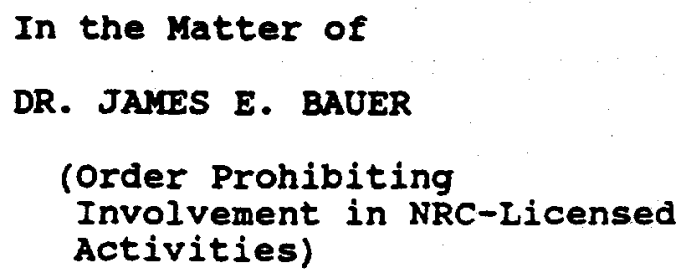

Docket No. IA-94-011

ASLBP NO. 94-696-05-EA

November 13, 1995

\section{MEMORANDUY AND ORDER \\ (Approving Settlement Agreement and Dismissing Proceeding)}

By immediately effective order dated May 10, 1994, the NRC staff (1) prohibited Dr. James E. Bauer from being named on an NRC license in any capacity and from otherwise performing licensed activities for a period of five years from the date of the order; and (2) required for two years thereafter that Dr. Bauer notify the NRC of any involvement in Iicensed activities to assure that the NRC can monitor the status of Dr. Bauer's compliance with the Commission's regulatory requirements. See 59 Fed. Reg. 25,673 (1994). This proceeding was convened at the request of $\mathrm{Dr}$. Bauer to contest the validity of the staff's order. See 59 Fed. Reg. 30,376 (2994). Now, by joint motion dated November 2, 1995, Dr. Bauer and the staff request that we approve a settlement agreement they have provided and dismiss this proceeding. $350 \leqq 501$ 
Anong other things, the settlement agreement reduces to three years the prohibition on Dr. Bauer's involvement in licensed activities. It also outlines the staff's agreement not to take any additional enforcement action against $D r$. Bauer based on either the facts set forth in the May 10, 1994 order or the facts and assertions revealed by a related staff investigation (No. 1-93-065R). Additionally, it provides that the settlement should not be considered as either an admission regarding or a resolution of any of the natters that formed the basis for the May 1994 staff enforcement order.

Pursuant to section 81 and subsections (b) and (o) of section 161 of the Atomic Energy Act of 1954, 42 U.S.C. $\$ \S 2111,2201(b), 2201(0)$, and 10 C.F.R. \$2.203, we have reviewed the parties' settlement accord to determine whether approval of the agreement and termination of this proceeding is in the public interest. Based on that review, and according due weight to the position of the staff, we have concluded that both actions are consonant with the public interest. Accordingly, we grant the parties' joint motion 
to approve the settlement agreoment and dismiss this proceeding.

For the foregoing reasons, it is this thirteenth day of November 1995, ORDERED, that:

1. The November 2, 1995 joint motion of the parties is granted and we approve their November 3, 1995 "settlement Agreement," which is attached to and incorporated by reference in this memorandum and order. ${ }^{2}$

1 The settlement agreement attached to the parties' November 2, 1995 motion was dated November 1, 1995. This document was a facsimile copy that did not have the original signatures of Dr. Bauer and his counsel. By letter dated November 7,1995 , staff counsel provided the settlement agreement with the original signatures of Dr. Bauer and his counsel. This document, which is dated November 3,1995 , is attached to this memorandum and order. 
2. This proceeding is dismissed.

THE ATOMIC SAFETY

AND LICENSING BOARD ${ }^{2}$

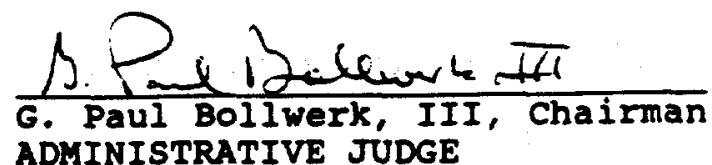
ADMINISTRATIVE JUDGE
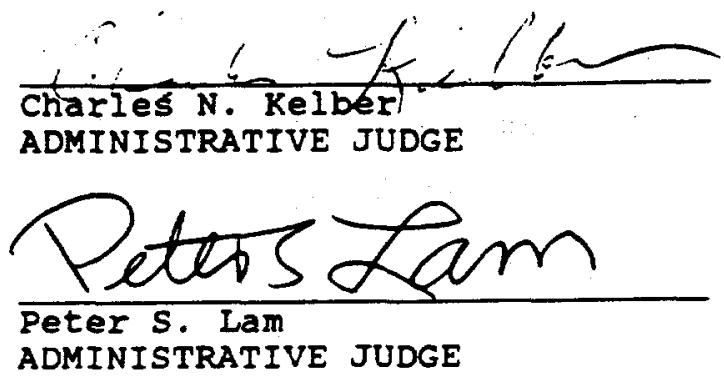

Rockville, Maryland

November 13,1995

2 Copies of this memorandum and order are being sent this date to counsel for Dr. Bauer by facsimile transmission and to staff counsel (without the accompanying attachment) by E-mail transmission through the agency's wide area network system. 
ATTACHMENT 1

NUREG-0940, PART I

A-41 


\title{
UNITED STATES OF AMERICA \\ NUCLEAR REGULATORY COMMISSION
}

\section{BEFORE THE ATOMIC SAFETY AND LICENSING BOARD}

\author{
In the Matter of \\ DR. JAMES E. BAUER \\ (Order Prohibiting Involvement \\ in NRC-Licensed Activities)
}

$\begin{array}{ll} & \text { ) } \\ & \text { ) Docket No. IA-94-011 } \\ & \text { ) ASLBP No. 94-696-05-EA }\end{array}$

\section{SETTLEMENT AGREEMENT}

On May 10. 1994, the staff of the Nuclear Regulatory Commission (Staff) issued an "Order Prohibiting Involvement in NRC Licensed Activities (Effective Immediately)" (Staff's Order) to Dr. James E. Bauer. 59 Fed. Reg. 25673 (May 17, 1994). On May 26, 1994, Dr. Bauer answ'ered the Staff's Order, denying the violations alleged in the Staff's Order and requesting a hearing. "Answer and Request for Hearing of James E. Bauer, M.D. M.Div. to May 10. 1994 Order Prohibiting Involvement in NRC-Licensed Activities (Effective Immediately)."

The parties to the above-captioned proceeding, the Staff and James E. Bauer, M.D., agree that it is in the public interest to terminate the above-captioned proceeding, without further litigation and agree to the following terms and conditions:

1. Dr. Bauer agrees to withdraw his request for a hearing, dated May 26, 1994.

2. Dr. Bauer further agrees to refrain from engaging in, and is hereby prohibited from engaging in, any NRC-licensed activities for a period of three years from the date of the Order Prohibiting Involvement in NRC-Licensed Activities, i.e., from May 10, 1994 through 
May 10, 1997. Such prohibition inclucies ar.y and all activities that are conducted pursuant to a specific or general license issued by the NRC, including, but not limited to, those activities of Agreement State licensees conducted pursuant to the authority granted by 10 C.F.R. $\S 150.20$.

3. For a period of two years following the above-specified three year period, i.e., from May 10, 1997 through May 10, 1999 in the event that Dr. Bauer becomes involved with NRC-licensed activities, Dr. Bauer agrees to provide, within 20 days of his acceptance of any employment offer involving NRC-licensed activities or any time he otherwise becomes involved in NRC-licensed activities, written notice to the Director, Office of Enforcement, U.S. Nuclear Regulatory Commission, Washington, D.C. 20555 of the name, address, and telephone number of the employer or the licensed entity where the licensed activities are or will be conducted and a detailed description of his duties and activities in which he is or will be involved.

4. In consideration of Dr. Bauer's agreement to the conditions of paragraphs 2 and 3 of this Settlement Agreement, the Staff agrees not to take any further enforcement action against Dr. Bauer based on a) the same facts outlined in the Order Prohibiting Involvement in NRC Licensed Activities (Effective Immediately), dated May 10, 1994 and b) any other facts or assertions revealed as a result of the NRC's Office of Investigation's investigation (No. 1-93-065R) relating to Dr. Bauer's activities. In the event that Dr. Bauer fails to comply with the conditions set forth in either paragraph 2 or 3 of this Settlement Agreement, the Staff expressly reserves the right to take whatever action necessary and appropriate to enforce the terms of this Settlement Agreement. 
5. The Staff and Dr. Bauer understand and agree that this Settlement Agreement is limited to the issues in and the parties to the above-captioned proceeding.

6. The Staff and Dr. Bauer agree that this Settlement Agreement does not constitute and should not be construed to constitute any admission or admissions in any regard by Dr. Bauer regarding any matters set forth by the NRC in the Order Prohibiting Involvement in NRC-Licensed Activities.

7. The Staff and Dr. Bauer also agree that the matters upon which the Order is based have not been resolved as a result of this Settlement Agreement. This Settlement Agreement shall not be relied upon by any person or other entity as proof or evidence of any of the matters set forth in the Order Prohibiting Involvement in NRC-Licensed Activities. 


$$
-4 .
$$

8. The Staff and Dr. Bauer shall jointly move the Atomic Safety and Licensing Board for an order approving this Settlement Agreement and terminating the above-captioned proceeding.

FOR JAMES E. BAUER, M.D.:

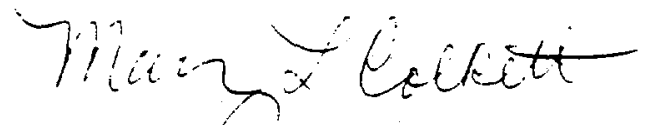

Marcy L. Colkitt

Counsel for James E. Bauer, M.D.

Tanes soved o. D.

Dated Rockville. Maryland

this $\_$day of November, 1995

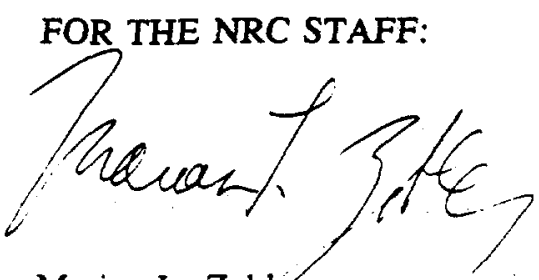

Mariar: L. Zobjer

Counsel for NRC Staff 


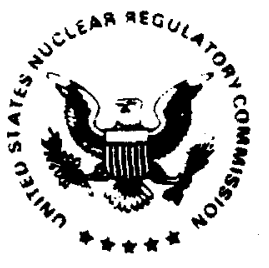

UNITED STATES

NUCLEAR REGULATORY COMMISSION

WASHINGTON, D.C. 20565-0001

$$
\text { ills } \div 8 \text { : } 904
$$

IA $94-020$

Mr. Paul A. Bauman

(HOME ADDRESS DELETED

UNDER 10 CFR 2.790)

Dear Mr. Bauman

SUBJECT: ORDER REQUIRING. NOTIFICATION TO NRC PRIOR TO INVOLVEMENT IN NRCLICENSED ACTIVITIES (EFFECTIVE IMMEDIATELY)

The enclosed Order Requiring Notification of Involvement in NRC-Licensed Activities (Effective Immediately) is being issued as a consequence of your actions while employed by the American Inspection Company, Inc., (AMSPEC) between late 1989 and March 1, 1992. The NRC Office of Investigations (OI) conducted an investigation and concluded that you deliberately: (1) falsified employee training records of numerous radiography employees of AMSPEC; (2) failed to train numerous radiography employees of AMSPEC; (3) provided examinees with answers to examination questions and personaliy aided and assisted employees in order to achieve required test scores; (4) provided false information to the Commission regarding the qualification of AMSPEC employees in an NRC 1 icense amendment application; (5) falsified records of quarterly personnel radiation safety audits; and (6) submitted false

information regarding the iraining and givalification of two individuals to the Commission in an app'icatioll for an NRC "1 icense renewal. As detailed in the eaclosed Order, your actions caused AMSPEC to be in violation of 10 CFR 30.9 , 34.11 , and 34.31 of the Commission's requirements.

Your assistance to the United States Attorney in his development of cases against others is appreciated. As a result, we are not prohibiting you from working in NRC-licensed activities. However, we believe that it is appropriate that the NRC be notified when you become invoived in NRC licensed activities. Therefore, the enclosed order is being issued to you. Failure to comply with the provisions of this Order may result in civil or criminal sanctions.

Questions concerning this Order should be addressed to Mr. James Lieberman, Director, Office of Enforcement, who may be reached at (301) 504-2741. 
In accordance with 10 CFR 2.790 of the NRC's "Rules of Practice," a copy of this letter and the enclosure will be placed in the NRC's Public Document Room.

Sincerely,

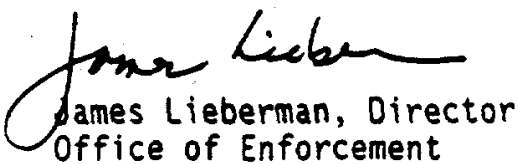

Enclosures:

1. Order

2. Synops is 
In the Matter of

Paul A. Bauman

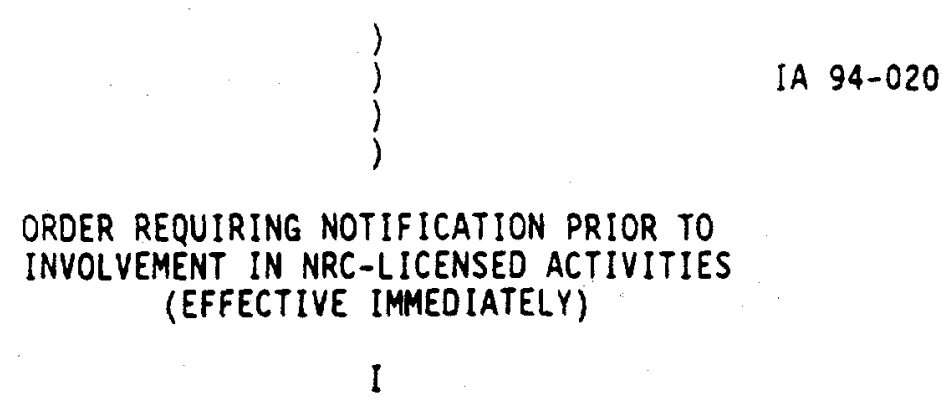

Paul A. Bauman has been employed in the field of industrial radiography since approximately 1981. In April 1987, Mr. Bauman was hired by the American Inspection Company, Inc., (Licensee or AMSPEC). AMSPEC held Materials License No. 12-24801-01 (License) issued by the Nuclear Regulatory Commission (NRC or Commission) pursuant to 10 CFR Parts 30 and 34 . This license authorized the conduct of industrial radiography activities in accordance with specified conditions. On April 30, 1992, the License was suspended as a result of significant safety violations and related safety concerns. Mr. Bauman was a Vice President and Radiation Protection Officer of AMSPEC when a majority of the violations discussed below occurred.

Between August 22, 1991 and November 12, 1992, the NRC Office of Investigations conducted an investigation of licensed activities at AMSPEC. During the course of this investigation, the License was suspended because a significant number of safety violations were uncovered. In addition, the investigation revealed that Mr. Bauman, in his capacity as a Vice President and Radiation Protection Officer of AMSPEC, deliberately: (1) falsified employee training records of numerous radiography employees of AMSPEC; (2) failed to train and certify numerous radiography employees of AMSPEC; (3) 
provided examinees answers to examination questions and personally aided and assisted employees in order to achieve required test scores; (4) provided, with Co-conspirator Daniel McCool, false information to the Commission regarding the qualification of AMSPEC employees in an NRC license amendment application; (5) falsified records of quarterly personnel radiation safety audits; and (6) submitted false information regarding the training and qualification of two individuals to the Commission in an application for an NRC license renewal.

10 CFR 34.31(a) provides that a licensee shall not permit any individual to act as a radiographer until such individual: (1) has been instructed in the subjects outlined in Appendix A of 10 CFR Part 34; (2) has received copies of and instruction in NRC regulations contained in 10 CFR Part 34 and in the applicable sections of 10 CFR Parts 19 and 20, NRC license(s) under which the radiographer will perform radiography, and the licensee's operating and emergency procedures; (3) has demonstrated competence to use the licensee's radiographic exposure devices, sealed sources, related handling tools, and survey instruments; and (4) has demonstrated understanding of the instructions in this paragraph by successful completion of a written test and field examination on the subjects covered. AMSPEC submitted a Radiation Safety Manual as a part of its license application dated September 20, 1986. A part of this manual prescribes the licensee's employee training program to satisfy the requirenents of Appendix A of 10 CFR Part 34. This manual was incorporated as a part of License Condition 17 of the AMSPEC license. In addition, 10 CFR 34.11 (d)(1) requires, in part, that an applicant have an inspection program that includes the observation of the performance of each radiographer and radiographer's assistant during an actual radiographic 
operation at intervals not to exceed three months. AMSPEC had an approved audit program that was incorporated as part of License Condition 17 to meet the requirements of 10 CFR 34.11 (d)(1). 10 CFR 30.9(a) requires, in part, that information provided to the Commission by a licensee, or information required by the Commission's regulations to be maintained by the licensee, shall be complete and accurate in all material respects. 10 CFR 30.10(a) requires, in part, that any 1 icensee or any employee of a licensee may not: (1) engage in deliberate misconduct that causes a licensee to be in violation of any rule, regulation, order, or term of any license, issued by the Commission, or (2) deliberately submit to the NRC information that the person submitting the information knows to be incomplete or inaccurate in some respect material to the NRC.

Between late 1989 and March 1, 1992, Mr. Bauman deliberately caused AMSPEC to violate 10 CFR 34.31 by falling to train and certify numerous radiography employees of AMSPEC as required and caused ASMPEC to violate 10 CFR 30.9 by deliberately falsifying training records to show that numerous employees of AMSPEC stationed at the Hess facility on St. Croix were properly trained in radiation safety. During 1990 and 1991 , Mr. Bauman violated License Condition 17 by providing unauthorized and improper aid to AMSPEC employees taking radiation safety examinations in that Mr. Bauman: (1) allowed the use of reference material during closed-book examinations; (2) permitted examinees to complete exaninations in an untimed, unmonitored setting; and (3) directly provided the examinees with answers to test questions. In June of 1990, Mr. Bauman caused AMSPEC to violate 10 CFR 30.9 by preparing an NRC license amendment letter to the NRC that deliberately contained false information regarding the qualification of three AMSPEC employees. In July and August of 
1991, Mr. Bauman caused AMSPEC to violate 10 CFR 30.9 and 10 CFR 34.11 by deliberately falsifying records of quarterly personnel radiation safety audits. In November of 1991, Mr. Bauman caused AMSPEC to violate 10 CFR 30.9 by conspiring with and directing his secretary to physically write answers on a required radiation safety test by annotating on the test the name of an AMSPEC employee and placing it in that employee's radiation safety records. Mr. Bauman violated 10 CFR 30.10 by deliberately submitting false information regarding the training and qualification of two individuals to the Commission in a December 20, 1991 application for an NRC license renewal.

On December 17, 1992, Mr. Bauman pled guilty to two felony counts. The first count involved conspiracy to violate 42 U.S.C. 2273 (section 223 of the Atomic Energy Act). The second count consisted of deliberately providing false information to the NRC in violation of 42 U.S.C. 2273 and 42 U.S.C. 22016 (section 161b of the Atomic Energy Act) and 10 CFR 30.9 and 10 CFR 30.10(a)(2) of the Commission's regulations.

The NRC must be able to rely on the Licensee and its employees to comply with NRC requirements, including the requirement to provide information and maintain records that are complete and accurate in all material respects. As a Vice President and Radiation Protection Officer (RPO) of AMSPEC, Mr. Bauman was responsible for ensuring that the Commission's regulations and License conditions were met and that records which were required to demonstrate compliance with the Commission's regulations and License conditions were true and accurate in all material aspects. Mr. Bauman's deliberate actions in 
causing the Licensee to violate 10 CFR $30.9,34.11$, and 34.31 and License Condition 17, and his deliberate misrepresentations to the NRC, are unacceptable and raise a question as to whether he can be relied on at this time to comply with NRC requirements and to provide complete and accurate information to the NRC.

Consequently, the NRC needs the capability to monitor his performance of licensed activities in order to be able to maintain the requisite reasonable assurance that licensed activities can be conducted in compliance with the Commission's requirements and that the health and safety of the oublic will be protected if Mr. Bauman is employed in NRC-licensed activities. Therefore, the public health, safety and interest require that for a period of three years from the date of this Order, Mr. Bauman shall notify the NRC of his employment by any person or entity engaged in NRC-licensed activities to ensure that the NRC can monitor the status of Mr. Bauman's compliance with the Commission's requirements and his understanding of his commitment to compliance. Furthermore, pursuant to 10 CFR 2.202, I find that the significance of the conduct described above is such that the public health, safety and interest require that this order be effective immediately.

IV

Accordingly, pursuant to sections $81,161 \mathrm{~b}, 161 \mathrm{i}, 182$ and 186 of the Atomic Energy Act of 1954, as amended, and the Commission's regulations in 10 CFR 2.202, 10 CFR 30.10, and 10 CFR 150.20, IT IS HEREBY ORDERED, EFFECTIVE IMMEDIATELY, THAT: 
For a period of three years from the date of the Order, Paul A. Bauman shall: Within 20 days of his acceptance of each employment offer involving NRC-licensed activities or his becoming involved in NRClicensed activities, provide notice to the Director, Office of Enforcement, U. S. Nuclear Regulatory Commission, Washington, D.C. 20555, of the name, address, and telephone number of the employer or the entity where he is, or will be, involved in the NRC-licensed activities. NRC-licensed activities are those activities which are conducted pursuant to a specific or general license issued by the NRC, including, but not limited to, those activities of Agreement State licensees conducted pursuant to the authority granted by 10 CFR 150.20. In the first notification Mr. Bauman shall include a statement of his commitment to compliance with regulatory requirements and the basis why the Commission should have confidence that he will now comply with applicable NRC requirements.

The Director, Office of Enforcement, may, in writing, relax or rescind any of the above conditions upon demonstration by Mr. Bauman of good cause.

In accordance with 10 CFR 2.202, Paul A. Bauman must, and any other person adversely affected by this Order may, submit an answer to this Order, and may request a hearing on this Order, within 20 days of the date of this Order. The answer may consent to this Order. Uniess the answer consents to this Order, the answer shall, in writing and under oath or affirmation, specifically admit or deny each allegation or charge made in this Order and 
shall set forth the matters of fact and law on which Mr. Bauman or any other person adversely affected relies and the reasons as to why the Order should not have been issued. Any answer or request for a hearing shall be submitted to the Secretary, U.S. Nuclear Regulatory Commission, Attn: Chief, Docketing and Service Section, Washington, $D C$ 20555. Copies also shall be sent to the Director, Office of Enforcement, U.S. Nuclear Regulatory Commission, Washington, $D C$ 20555, to the Assistant General Counsel for Hearings and Enforcement at the same address, to the Regional Administrator, NRC Region II, 101 Marietta Street, N. W., Suite 2900, Atlanta, Georgia 30323, and to . Paul A. Bauman if the answer or hearing request is by a person other than Paul A. Bauman. If a person other than Paul A. Bauman requests a hearing,that person shall set forth with particularity the manner in which his or her interest is adversely affected by this order and shall address the criteria set forth in 10 CFR $2.714(d)$.

If a hearing is requested by Paul A. Bauman or another person whose interest is adversely affected, the Commission will issue an Order designating the time and place of any hearing. If a hearing is held, the issue to be considered at such hearing shall be whether this Order should be sustained.

Pursuant to 10 CFR $2.202(C)(2)(i)$, Paul A. Bauman, or any other person adversely affected by this Order, may, in addition to demanding a hearing, at the time the answer is flled or sooner, move the presiding officer to set aside the immediate effectiveness of the Order on the ground that the Order, including the need for immediate effectiveness, is not based on adequate evidence but on mere suspicion, unfounded allegations, or error. 
In the absence of any request for hearing, the provisions specified in Section IV above shall be final 20 days from the date of this Order without further order or proceedings. AN ANSWER OR A REQUEST FOR HEARING SHALL NOT STAY THE IMMEDIATE EFFECTIVENESS OF THIS ORDER.

FOR THE NUCLEAR REGULATORY COMMISSION

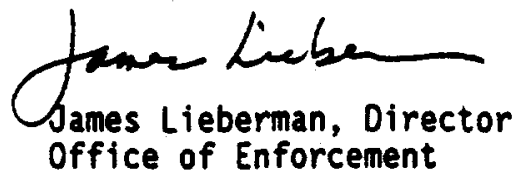

Dated at Rockville, Maryland this $x^{\text {thy }}$ day of August 1994 
SYNOPSIS

On August 22, 1991, the Regional Administrator, U.S. Nuclear Regulatory Commission (NRC), Region II, requested an investigation to determine whether officials, managers, and/or employees of The American Inspection Company, Inc. (AMSPEC), the licensee, had intentionally violated regulatory and license condition requirements set forth in 10 CFR Parts 20,30 , and 34 and the NRC Iicense of January 15, 1987, respectively. According to reported allegations, licensee management officials had permitted unqualified technicians to perform radiography operations at the Hess oil Virgin Islands Company (HOVIC) facility, st. Croix, U.S. Virgin Islands, which had contracted with AMSPEC for nondestructive examination services. Additionally, licenses officials allegedly: (1) discriminated (involuntary termination) against technicians for reporting radiation health and safety concerns, (2) falsified radiation safety training documents, (3) provided false and misleading information to the NRC, and (4) used source material in a manner not authorized by the license (Irradiation of mice).

The office of Investigations (OI) reviewed the circumstances of the alleged regulatory and license condition violations during which other improprieties by the licensee were identified. The investigation by oI did not substantiate that licensee management officials had terminated radiography technicians for reporting radiation health and safety concerns. It was concluded, however, that these licensee officials at the HovIC facility appeared insensitive to employee concerns of all topics, including radiation safety, and they were perceived by technicians as acting with apparent disregard concerning this issue. The investigation further determined that 1 icensee officials deliberately provided false and misleading radiation safetyrelated information to NRC representatives which was pertinent to the regulatory process. The investigation substantiated that the licensee, through actions of some radiation protection officers (RPOs), deliberately falaified radiation safety training records, inserted false records in technician files to give the impression required training was accomplished, and they also conspired to conceal theae training deflciencies and Improprieties from the NRC. The investigation surfaced and substantiated the allegation that licensee officials and RPOs deliberately falsified required personnel radiation safety audits and accompanying reports and they also created audit reports to make complete the radiation safety files of some technicians.

The investigation also disclosed and confirmed numerous instances of radiographers' assistants performing radjography without supervision and the deliberate falsiflcation of source utilization logs to give the appearance that required supervision was present, all with the apparent knowledge and concurrence of 11censee management offlclais. It was also determined during the investigation that 11 censee training officials (RPOs) frequently

Case No. 2-91-010R

NUREG-0940, PART I A-56 
failed to provide the operation and Emergency Procedures (OSEP) Manual to new employees prior to source utilization. The investigation also determined that some licensee RPOs were not trained, examined, and certified according to Radiation safety Program requirements and AMSPEC officials, including the radiation safety officer (RSO) and several RPOs, were aware of some of these violations and failed to cerrect them. Further, on at least. one occasion, the RSO and an RPo conspired to concoct a plausible explanation for the NRC as to why RPo examination/certification requirements were violated.

The investigation substantiated the allegation that radioactive source material was utilized improperly when an AMSPEC night shift supervisor, in the presence of technicians, radiographed a mouse during two to three consecutive source exposures at the HOVIC facility. The OI investigation, and a previous NRC inspection at the st. Croix location, also revealed instances in which AMSPEC technicians falled to observe required surveying and posting activities during radiography operations, actions which demonstrated either an apparent disregard for regulations and/or radiation safety training deficiencies. "Finally, the investigation disclosed that the RSO and other licensee management officials deliberately failed to perform required radiation safety review, Galuation, and oversight functions and responsibilities during the past 3 years. 


\section{UNITED STATES \\ NUCLEAR REGULATORY COMMISSION \\ WASHIMGTON, O.C. 20000-0001}

.ovember ij, 1994

IA 94-032

Michael J. Berna

[ADORESS DELETED

UNDER 10 (FR 2.790]

SUBJECT: ORDER PROHIBITING INVOLVEMENT IN NRC-LICENSED ACTIVITIES

(EFFECTIVE IMMEDIATELY)

(NRC INSPECTION REPORT NO. 030-04325-92001)

(NRC INVESTIGATION REPORT NO. 3-92-035R)

Dear Mr. Berna:

The enclosed Order Prohibiting Involvement in NRC-Licensed Activities (Effective Immediately) (Order) is being issued as a consequence of your actions while employed as the Radiation Safety Officer at the Amoco Refinery, Whiting, Indiana, in 1992. This Order prohibits your involvement in NRC-licensed activities for a period of three years from the date of this Order.

Pursuant to section 223 of the Atomic Energy Act of 1954, as amended, any person who willfully violates, attempts to violate, or conspires to violate, any provision of this Order shall be subject to criminal prosecution as set forth in that section.

Questions concerning this Order may be addressed to Mr. James Lieberman, Director, Office of Enforcement, who can be reached at (301) 504-2741.

In accordance with 10 CFR 2.790 of the NRC's "Rules of Practice," a copy of this letter and the enclosure with your home address removed will be placed in the NRC's Public Document Room.

FOR THE NUCLEAR REGULATORY COMMISSION

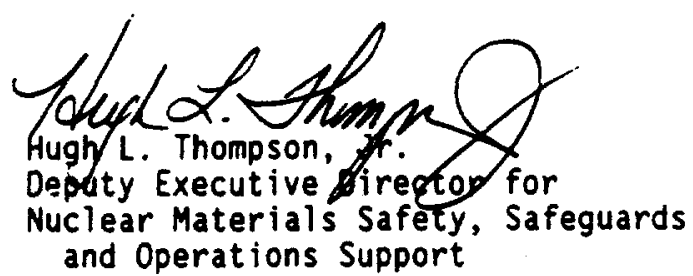

Enclosures:

1. Order Prohibiting Involvement in NRC Licensed Activities

2. Notice of Violation and Proposed Imposition of Civil Penalties to Amoco 
UNITED STATES

NUCLEAR REGULATORY COMMISSION

In the Matter of

MICHAEL J. BERNA

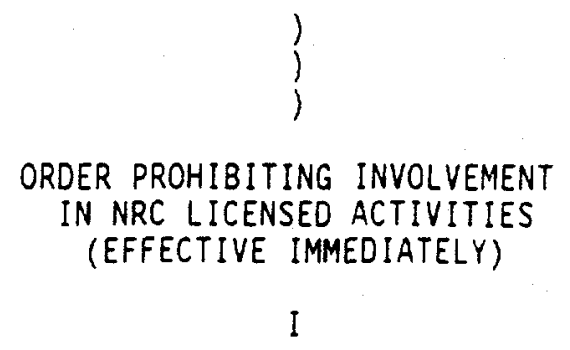

IA $94-032$

Amoco 0 il Company (Amoco or Licensee) was the holder of Byproduct Material License No. 13-00155-10 issued by the Nuclear Regulatory Commission (NRC or Commission) pursuant to 10 CFR Parts 30 and 34 . The license authorized the use of byproduct material (iridium-192 and cobali-60) for industrial. radiography in devices approved by the NRC or an Agreement State. The facility where licensed materials were authorized for use and storage was located at 2815 Indianapolis Boulevard, Whiting, Indiana. The use of licensed material was authorized at temporary job sites anywhere in the United States where the United States Nuclear Regulatory Commission maintains jurisdiction for regulating the use of licensed material. The License was originally issued on February 4, 1958, and was terminated on October 19, 1993.

Mr. Michael J. Berna performed duties as the Licensee's Radiation Safety Officer (RSO) from March 1990 until he was relieved of those duties on October 16, 1992.

On July 27, 1992, the NRC Region III office received information that Mr. Berna had not conducted field audits of radiographers and radiographer's assistants as required by license conditions and that Mr. Berna fabricated reports for the audits that he did not perform by documenting that the audits 
had been performed. The NRC conducted an inspection at the Licensee's Whiting, Indiana, refinery from September 15 to October 9, 1992. The NPC Office of Investigations (01) subsequently conducted an investigation. The Licensee conducted an investigation contemporaneously with the NRC inspection and investigation. Deliberate violations of NRC requirements were identified as a result of the NRC inspection and the investigation.

Condition 18.A of License No. 13-00155-10 incorporates the statements, representations, and procedures contained in the licerse application dated March 28, 1990. Item 10.3 of that application required, in part, that practicing radiographers and radiographer's assistants are to be audited at intervals not to exceed 3 months to meet the requirements of 10 CFR Part 34 and the Licensee's Operating and Emergency Procedures, and that the audits should be unannounced insofar as possible. Item 10.5 of that application required, in part, that certain records he generated and maintained, including a record of quarterly audits of radiographers and radiographer's assistants.

Mr. Berna admitted to the NRC in a sworn, transcribed interview on 0ctober 7 , 1992, that he knowingly failed to perform the required audits and that he deliberately falsified records to show that audits had been performed on at least ten occasions (February 6, 10, 12, and 29, Apri) 11, 22, 24, and 29, May 12, and September 1, 1992).

In addition, during the September 15, 1992, inspection the NRC inspector asked Mr. Berna if the field audits of radiographers and radiographer's assistants were unannounced. Mr. Berna told the NRC inspector that he did not give any advance notification to radiography personnel. However, the testimony of 
eight radiographers or radiographer's assistants indicated that Mr. Berna always informed them when he would be performing an audit.

Testimony provided by an Assistant Radiation Safety Oficer (ARSO) on November 5, 1992, indicated that at the request of Mr. Berna on or about September 15, 1992, the ARSO falsified at least two records of audits of radiographers and radiographer's assistants for May 1992. Also, testimony provided to OI by another ARSO on December 17, 1992, indicated that at the request of Mr. Berna during August 1991, this ARSO falsified at least two records of audits of radiographers and radiographer's assistants.

These actions are contrary to the audit requirements and the records generation and maintenance requirements of the License, and a violation of 10 CFR 30.9(a), "Completeness and Accuracy of Information," and 10 CFR $30.10(a)(1)$ and (2), "Deliberate Misconduct," of the Commission's regulations.

The Licensee conducted an internal investigation and based on the results of its investigation the Licensee suspended Mr. Berna's emplayment for one month without pay. On December 1, 1992, a Confirmatory Order Modifying License (Effective Immediately) was issued to the Licensee, which confirmed, among other things, that the Licensee would prohibit Mr. Berna from participating in any NRC licensed activities, including the position of RSO. 
Based on the above, it appears that Mr. Berna engaged in deliberate misconduct from August 1991 through approximately September 15, 1992, by failing to conduct field audits of radiographers and radiographer's assistants at the interval specified in the NRC Byproduct Material License, and by creating false records for audits which he did not conduct, thus making the record appear as though a field audit was performed at the specified interval. Mr. Berna also engaged in deliberate misconduct when he requested two ARSOs to falsify field audit records. Mr. Berna engaged in additional misconduct when he told an NRC inspector that field audits of radiographers or radiographer's assistants were unannounced. Mr. Berna's actions caused the Licensee to be in violation of the Amoco License, as well as 10 CFR 30.9, and constituted violations of 10 CFR 30.10 of the Commission's regulations. As the Licensee's RSO, Mr. Berna supervised the radiation safety program associated with NRC Byproduct Material License No. 13-00155-10 and was responsible for ensuring that the Commission's regulations and license conditions were met.

Consequently, I lack the requisite reasonable assurance that licensed activities can be conducted in compliance with the Commission's requirements and that the health and safety of the public will be protected if Mr. Berna were permitted at this time to be involved in NRC-licensed activities. Therefore, the public health, safety and interest require that Mr. Berna be prohibited from any involvement in NRC-licensed activities for a period of three years from the date of this Order. Additionally, Mr. Berna is required to notify the NRC of his first employment in NRC-1icensed activities licensed by the NRC following the prohibition period. Furthermore, pursuant to 10 CFR 
2.202, I find that the significance of Mr. Berna's conduct described above is such that the public health, safety and interest require that this order be immediately effective. A longer period was not imposed because of the issuance of the December 1, 1992 Confirmatory Order Modifying License (Effective Immediately).

4ccordingly, pursuant to sections $81,161 \mathrm{~h}, 161 \mathrm{i}, 1610,182$ and 186 of the Atomic Energy Act of 1954, as amended, and the Commission's regulations in 10 CFR 2.202, 10 CFR Part 30, and 10 CFR Part 34, IT IS HEREBY ORDERED, EFFECTIVE IMMEDIATELY, THAT:

A. Michael J. Berna is prohibited for three years from the date of this Order from engaging in NRC-licensed activities. NRC-licensed activities are those activities that are conducted pursuant to a specific or general license issued by the NRC, including, but not limited to, those activities of Agreement State licensees conducted pursuant to the authority granted by 10 CFR 150.20 .

B. The first time Mr. Berna is employed in NRC-licensed activities following the three-year prohibition, he shall, within 20 days of his acceptance of the employment offer involving NRC-licensed activities, notify the Director, Office of Enforcement, U. S. Nuclear Regulatory Commission, Washington, $D C$ 20555, and the Regional Administrator, NRC Region III. The notice shall include the name, address, and telephone number of the employer or the entity where he is, or will be, involved 
in the NRC-licensed activities. In the first notification, Mr. Berna shall include a statement of his commitment to compliance with regulatory requirements and the basis why the Commission should have confidence that he will now comply with applicable NRC requirements.

The Director, Office of Enforcement, may, in writing, relax or rescind any of the above conditions upon demonstration by Mr. Berna of good cause.

In accordance with 10 CFR 2.202, Mr. Berna must, and any other person adversely affected by this Order may, submit an answer to this Order, and may request a hearing within 20 days of the date of this Order. The answer may consent to this Order. Unless the answer consents to this Order, the answer shall, in writing and under oath or affirmation, specifically admit or deny each allegation or charge made in this Order and shall set forth the matters of fact and law on which Mr. Berna or other person adversely affected relies and the reasons as to why the Order should not have been issued. Any answer or request for a hearing shall be submitted to the Secretary, U. S. Nuclear Regulatory Commission, ATTN: Chief, Docketing and Service Section, Washington, DC 20555. Copies also shall be sent to the Director, Office of Enforcement, U. S. Nuclear Regulatory Commission, Washington, DC 20555; to the Assistant General Counsel for Hearings and Enforcement at the same address; to the Regional Administrator, Region III, U. S. Nuclear Regulatory Commission, 801 Warrenville Road, Lisle, Illinois 60532-4351; and to Mr. Berna, if the answer or hearing request is by a person other than Mr. Berna. If a person other than Mr. Berna requests a hearing, that person 
shall set forth with particularity the manner in which ris or her interest is adversely affected by this Order and shall address the criteria set forth in 10 CFR $2.714(d)$.

If a hearing is requested by Mr. Berna or a person whose interest is acversely affected, the Commission will issue an Order designating the time and place of any hearing. If a hearing is held, the issue to be considered at such hearing shall be whether this order should be sustained.

Pursuant to 10 CFR $2.202(\mathrm{C})(2)(\mathrm{i})$, Mr. Berna, or any other person adversely affected by this Order, may, in addition to demanding a hearing, at the time the answer is filed or sooner, move the presiding officer to set aside the immediate effectiveness of the order on the ground that the order, including the need for immediate effectiveness, is not based on adequate evidence but on mere suspicion, unfounded allegations, or error.

In the absence of any reciest for a hearing, the provisions specified in Section IV above shall be final 20 days from the date of this Order without further order or proceedings. AN ANSWER OR A REQUEST FOR HEARING SHALL NOT STAY THE IMMEDIATE EFFECTIVENESS OF THIS ORDER.

FOR THE NUCLEAR REGULATORY COMMISSION

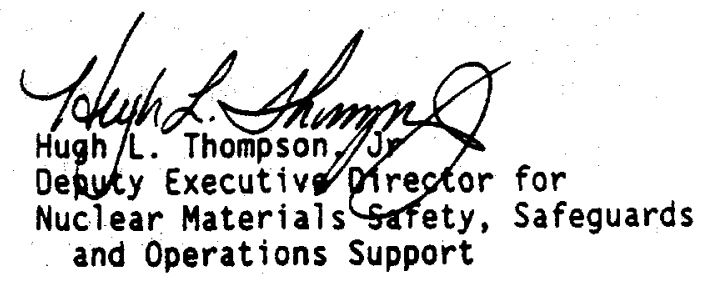

Dated at Rockville, Maryland this/5aday of November 1994 


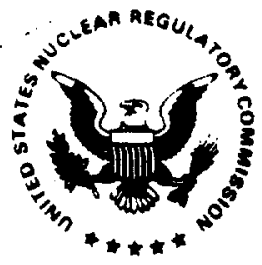

UNITED STATES

NUCLEAR REGULATORY COMMISSION

WASHINGTON, D.C. 20065-0001

SEP $\cap 8$ iSS4.

Docket No. 030-02551

License No. 29-12417-01

IA 94-023

Jerome E. Bodian, M.D.

[HOME ADDRESS DELETED

UNDER 2.790]

Dear Dr. Bodian:

SUBJECT: CONFIRMATORY ORDER (EFFECTIVE IMMEDIATELY)

On June 24, 1993, the NRC sent you a Demand for Information (DFI) based on several apparent violations of NRC requirements including (1) administration of doses to patients without first checking the dose in a dose calibrator, and (2) making false statements to the NRC during an NRC inspection at your facility on April 6, 1992, and subsequent telephone conversation on ApriT 7 , 1992 with NRC staff. The DFI required, in part, that you provide the reasons why, in light of the apparent violations described therein, the NRC should not issue an order that precludes you from any involvement in NRC 1 icensed activities in the future.

In your sworn response dated July 20, 1993, to the DFI, you: (1) stated that on infrequent occasions, a precalibrated dose of radioiodine was administered without prior use of a dose calibrator; (2) reiterated a previous request that your license be terminated; and (3) pointed out that you have never used the Englewood Hospital's license on a personal basis and any administration of radiopharmaceuticals to your patients at the Englewood Hospital was done under the supervision of the hospital radiology department.

Based on a NRC Office of Investigation report issued on July 26,1993 , the NRC Staff has determined that you dellberately failed to measure doses before administration to patients, and deliberately provided inaccurate information to the NRC during the April 6, 1992 inspection and the April 7, 1992 telephone conversation. A copy of the synopsis of the investigation is enclosed.

Although the MRC issued amendment No. 07 on September 27, 1993, terminating your license, in telephone conversations between Dr. Ronald R. Bellany of the NRC Region I office and yourself on July 18,19, and 20, 1994, you agreed to the issuance of an Order that would confirm that you would not participate in activities licensed by the NRC at any facility for a period of five years, and would notify the KRC the first time (if any) you engage in licensed activities after the five year prohibition expires. The enclosed Confirmatory order (Effective Immediately) confirms these commitments.

Question concerning the Order may be addressed to Ms. Patricia Santiago, Assistant Director for Materials, Office of Enforcement, at telephone number (301) 504-3055. 
In accordance with 10 CFR 2.790 of the NRC's "Rules of Practice," a copy of this letter, its enclosures, and your response will be placed in the NRC's Public Document Room.

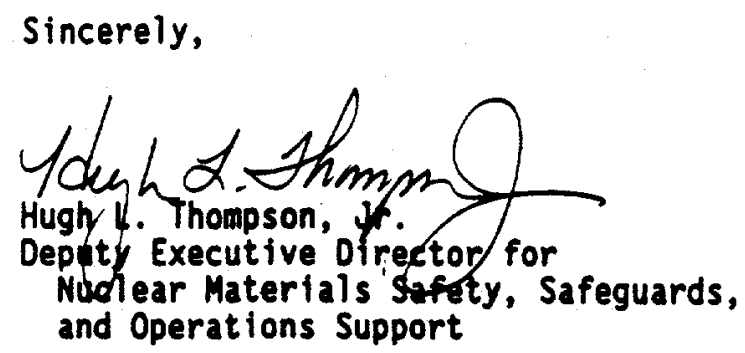

Enclosures:

1. Confirmatory Order (Effective Immediately)

2. OI Report Synopsis

cc w/encls:

Public Document Room (POR)

Nuclear Safety Information Center (NSIC)

State of New Jersey

Englewood Hospital 
On May 22, 1992, the Office of Investigations (OI), U.S. Nuclear Regulatory Commission (NRC), Field Office Region I, initiated an investigation to determine if the licensee intentionally violated NRC regulations by providing inaccurate and/or false information to NRC staff during an April 6, 1992, inspection, and April 7, 1992, telephone conversation. Specifically, the information concerned the licensee having doses of lodine-131 (I-13i) assayed by a technologist at Englewood Hospital (EH) prior to the administration of the $1-131$ to patients.

Based on the evidence, OI concludes that the licensee deliberately failed to measure the activity of each radiopharmaceutical dose before medical use. In addition, the licensee deliberately provided inaccurate and/or fal se

information to NRC staff during the April 6, 1992, inspection and April 7, 1992, telephone conversation.

OI also concludes that the licensee deliberately failed to conduct annual survey meter calibrations.

There is insufficient evidence to conclude that the licensee deliberately failed to possess a dose calibrator for the measurement of patient doses. There is also insufficient evidence to conclude that the itcensee deliberately failed to possess appropriate radiation detection and radiation measurenent survey instrumentation. 
UNITED STATES

NUCLEAR REGULATORY COMMISSION

In the Matter of

JEROME E. BODIM: M.D.

Englewood, New Jersey

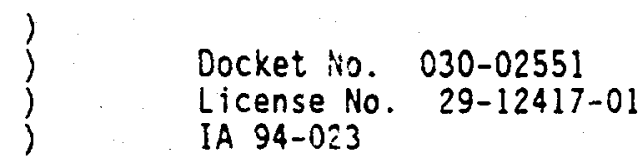

CONFIRMATCRY ORDER (EFFECTIVE IMMEDIATELY)

I

Jerome E. Bodian (Licensee er Jr. Bodian) was the holder of NRC License No. 29-12417-01 (License) issued ay the Nuclear Regulatory Commission (NRC or Commission) pursuant to 10 CFR Parts 30 and 35 on September 11,1967 and last renewed in its entirety on August 20, 1990. The License authorized the Licensee to possess and use icdine-131 as iodide for uptake studies, thyroid imaging, and the treatment of hypothyroidism and cardiac disfunction. The License was due to expire on August 30, 1995; however on January 25, 1993, the Licensee requested that the License be terminated. The NRC granted this request for termination, and Amendment No. 07 was issued to the Licensee on September 27, 1993, terminating the License.

II

On April 6, 1992, an NRC inspection was conducted at the Licansee's facility in Englewood, New Jersey. Ouring the inspection, the NRC identified several violations of NRC requirements, including the failure to possess and use a dose calibrator to assay therapeutic doses of iodine-131 prior to administration to patients. Also during the inspection, Dr. Bodian told the inspector that he took doses of lodine-131 to Englewood Hospital for calibration. During a telephone conversation with Region I staff on April 7, 1992, Dr. Bodian stated that. (1) although he did not possess a dose 
caltbrator, he had a technologist at Englewood Hospital perform the dose measurements for almost all patients he had treated; (2) all measurements of doses were within \pm 10 percent of the prescribed dose; and (3) the results of these measurements were recorded in the patient charts.

Shortly after the inspection, the NRC issued a Confirmatory Action Letter to the Licensee on April 9, 1992, which confimed, in part, the Licensee's agreement to terminate patient treatments with any radiopharmaceutical authorized by the NRC until such time as the Licensee established, and submitted to the NRC for approval, a progran that included all of the required equipment and procedures required by 10 CFR Part 35. Such a program was not established and patient treatment has not resumed. The NRC Office of Investigations initiated an investigation on May 22, 1992. Or. Bodian requested, in a letter dated January 25, 1993, that the License be terwinated.

In view of Or. Bodian's willful failure to adhere to MRC requirements, as well as the apparently willful fallure to provide complete and accurate information to the MRC, thereby endangering patients to whom the doses were administered, the MRC needed certain information to determine whether there existed reasonable assurance that Dr. Bodian's activities conducted under other NRC licenses would be perfornad safely and in accordance with requirements. Accordingly, a Danand for Information (DFI) was issued to Or. Bodian on June 24, 1993, that requested him to list all NRC Iicenses on which he was then listed as an authorized user, and to explain why the NRC should not issue an order to preclude him from any involvement in licensed activities in the future. 
On July 20, 1993, Dr. Bodian responded to the Demand for Information stating that (1) on infrequent occasions a precalibrated dose of radioiodine was administered without prior use of dose calibrator; (2) a request for termination of his 11 cense (No. 29-12417-01) was made on January 25, 1993; and (3) his listing (as an authorized user) on the Englewood Hospital license (No. 29-08519-01) was a carry over from years 290, and that any administration of radiopharmaceuticals to his patients at Englewood Hospital was done under the superviston of the hospital radiology department.

The NRC OI report issued July 26, 1993 determined that notwithstanding Or. Bodtan's statements to the MRC, the doses, with a few exceptions, were not assayed with a dose calibrator prior to adainistration, even though Dr. Bodian was aware that such assays were required. This finding is based on the fact that al though the Licensee's records indicate that 30 iodine-131 doses were provided to patients between January 1990 and April 1992, the MRC has found that most doses were not assayed for the Licensee in the Hospltal's dose calibrator during that time. This willful fallure to adhere to this requirement, as well as the willful false stateants to the NRC during the inspection on April 6. 1992 and the April 7, 1992 telephone conversation, constitute violations of 10 CFR 35.53, 10 CFR 30.9, and 10 CFR 30.10.

\section{III}

Based on the above, it appears that Dr. Bodian, the Lfcensee, engaged in deliberate aisconduct that constitutes a violation of 10 CFR $30.10(a)(1)$ and that has caused the Licensee to be in violation of 10 CFR 35.53. It further

NUREG-0940, PART I A-71 
appears that Or. Bodian deliberately provided to NRC inspectors information that he knew to be incomplete or inaccurate in some respect material to the NRC, in violation of 10 CFR 30.09 and 10 CFR 30.10(a)(2). Or. Bodian has demonstrated an unwillingness to comply with Commission requirements. NRC must be able to rely on its licensees to comply with NRC requirements, including the requirement to provide complete and accurate information. Willful violations are of particular concern to the Comisston because they undermine the Commission's reasonable assurance that ifcensed activities will be conducted in accordance with NRC requirements. Dr. Bodian's actions have raised serious doubt as to whether he can be relled upon to comply with MRC requirements and to provide complete and accurate information to the MRC. Consequently, protection of the public health, safety and interest require that Dr. Bodian be prohtbited from engaging in MRC-licensed activities for a period of 5 years and to notify the MRC prior to resumption of any NRClicensed activities at any factlity after termination of the five year prohibition.

In telephone conversations on July 18, 19, and 20, 1994, with Dr. Ronald R. Bellamy of the MRC Region $I$ offtce, Dr. Bodian agreed not to be involved in any MRC-IIcensed activities for a pertod of five years, and to notify the NRC prior to resuption of any licensed activities at any facllity after that five year prohibition. I find that the Or. Bodian's comitents as set forth in that conversation are acceptable and necessary and conclude that with these comitments the protection of the public health and safety is reasonably assured. In view of the foregoing, I have deterwined that the public health and safety require that the Dr. Bodian's comitments in the telephone 
conversations of July 18, 19, and 20, 1994 be confirmed by this Order. Dr. Bodian has agreed to this action. Pursuant to 10 CFR 2.202, I have also determined that the significance of the violations described above is such that the public health and safety require that this Order be immediately effective.

Accordingly, pursuant to sectlons $81,1616,1611,1610,182$ and 186 of the Atomic Energy Act of 1954, as amended, and the Commission's regulations in 10 CFR 2.202 and 10 CFR Parts 30 and 35, IT IS HEREBY ORDERED THAT:

1. For a period of five years from the date of this Confirmatory Order, Jerome E. Bodian, M.D., shall not engage in any MRC-licensed activities. NRC-licensed activities are those activities which are conducted pursuant to a specific or general license issued by the MRC, including, but not 1 inited to, those activities of Agreement State IIcensees conducted pursuant to the authority granted by 10 CFR 150.20.

2. When, for the first tim, Dr. Bodian is employed in MRC-licensed activitles following the five year prohibition, he shall notify the Regional Adatnistrator, MRC Reglon 1, 475 Allendale Road, King of Prussia, Pennsylvanta 19406, within 20 days prior to engaging in MRCIlcensed activities, including activities under an Agreament State Ilcense when activities under that Itcense are conducted in areas of MRC 
jurisdiction pursuant to 10 CFR 150.20 . The notice shall include the name, address, and telephone number of the NRC or Agreement State licensee and the location where licensed activities will be performed.

The Director, Office of Enforcement, may, in writing, relax or rescind any of the above conditions upon a showing by Dr. Bodian of good cause.

Any person adversely affected by this Confirmatory Order (Effective Immediately), other than Dr. Bodian, may request a hearing within 20 days of its issuance. Any request for a hearing shall be submitted to the Secretary, U.S. Nuclear Regulatory Commission, ATTM: Chief, Docketing and Service Section, Washington, D.C. 20555. Copies also shall be sent to the Director, Office of Enforcement, U.S. Nuclear Regulatory Comission, Washington, D.C. 20555, to the Assistant General Counsel for Hearings and Enforcement at the same address, to the Regional Adainistrator, NRC Region I, 475 Allendale Road, King of Prussia, Pennsylvania 19406, and to Or. Bodian. If such a person requests a hearing, that person shall set forth with particularity the manner in which his or hor interest is adversely affected by this Order and shall address the criterla set forth in 10 CFR 2.714(d).

If a hearing is requested by a person whose interest is adversely affected, the Comission will issue an Order designating the time and place of any 
hearing. If a hearing is held, the issue to be considered at such hearing shall be whether this Confirmatory Order (Effective Immediately) should be sustained.

Pursuant to 10 CFR 2.202 (c)(2)(i), any person adversely affected by this Order, other than Dr. Bodian, may, in addition to demanding a hearing, at the time the answer is filed or sooner, move the presiding officer to set aside the immediate effectiveness of the Order on the ground that the Order, including the need for imediate effectiveness is not based on adequate evidence but on mere suspicion, unfounded allegations, or error.

In the absence of any request for hearing, the provisions specified in Section IV above shall be final 20 days from the date of this order without further order or proceedings. AN ANSWER OR REQUEST FOR A HEARING SHALL NOT STAY THE IMMEDIATE EFFECTIVENESS OF THIS ORDER.

FOR THE NUCLEAR REGULATORY COMMISSION

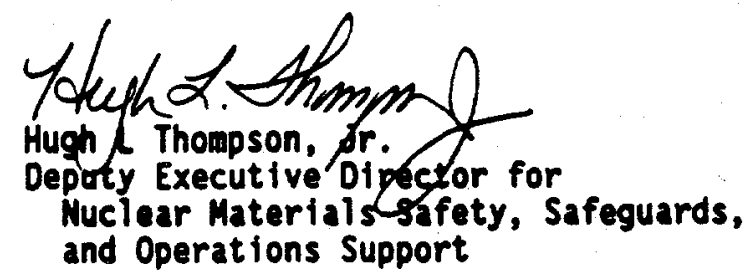

Dated at Rockville, Maryl and this $8+h$ day of September 1994 


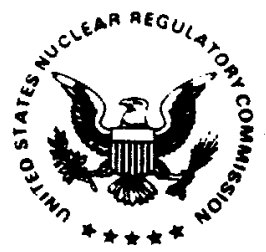

UNITED STATES

NUCLEAR REGULATORY COMMISSION

WASHINGTON, O.C. 2005-0001

February 23, 1996

IA $96-009$

Mr. Eugene Bolton

[HOME ADORESS OELETED

UNDER 2.790]

SUBJECT: ORDER PROHIBITING INVOLVEMENT IN NRC-LICENSED ACTIVITIES

(EFFECTIVE IMMEDIATELY)

Dear Mr. Bolton:

The enclosed Order is being issued as a result of an NRC investigation by the Office of Investigations (OI) which in part, concluded the following: 1) you knowingly maintained and substituted a cold urine sample at the time you were required to submit to a Fitness-For-Duty (FFD) test, and that you knew your actions were in violation of procedures when you submitted the surrogate sample; and 2) you admitted to being successful in providing surrogate samples in the past.

Subsequent to the OI investigation, on October 6, 1995, a Demand for Information (DFI) was issued to you based on the OI findings. A copy of the synopsis of the investigation was enclosed. The DFI requested that you:

(1) identify whether you currently are empioyed by a company subject to NRC regulation, and if so, describe in what capacity; and (2) describe why the NRC should have confidence that you will meet NRC requirements to provide complete and accurate information to the NRC and its licensees in the future. As of this date you have not responded.

The DFI further stated that if no answer was filed, the Commission may institute a proceeding pursuant to 10 CFR 2.202 or take some other actions as may be necessary to insure compliance with regulatory requirements and that if you did not respond as specified, the NRC would proceed on the bas is of available information. Therefore, the NRC has determined, based on the available information and to insure compliance with regulatory requirements, that the enclosed Immediately Effective Order prohibiting your involvement in NRC-licensed activities is appropriate. The order states the following: you are prohibited for five years from March 9, 1993, the date your unescorted access was terminated by New York Power Authority (NYPA), from seeking unescorted access to facilities licensed by the NRC.

Pursuant to Section 223 of the Atomic Energy Act of 1954, as amended, any person who willfully violates, or attempts to violate, or conspires to violate, any provision of this order shall be subject to criminal prosecution as set forth in that section. 
A copy of this letter and its enclosures are being sent to Mr. Leslie M. Hill, Jr., Site Executive Officer, NYPA, Indian Point 3. The NYPA is not required to provide a response to the Order, but may do so if it desires within 30 days under oath or affirmation.

Questions concerning this Order should be addressed to Mr. James Lieberman, Director, Office of Enforcement, who can be reached at (301) 415-2741.

In accordance with 10 CFR 2.790 of the NRC's "Rules of Practice," a copy of this letter, its enclosures, and your response will be placed in the NRC Public Document Room (POR).

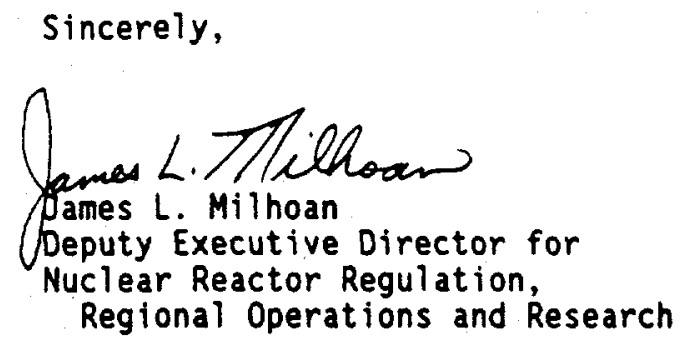

Docket No. $50-286$

License No. DPR-64

Enclosure:

Immediately Effective Order

cc w/encls:

L. Hill, Site Executive Officer 
UNITEO STATES

NUCLEAR REGULATORY COMMISSION

In the Matter of

Mr. Eugene Bolton

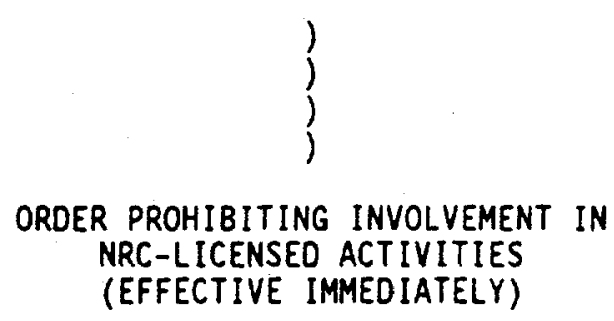

Eugene Bolton (Mr. Bolton) was employed as a Senior Nuclear Production Technician at the New York Power Authority (NYPA) (Licensee). Licensee is the holder of License No. DPR-64 issued by the Nuclear Regulatory Commission (NRC or Commission) pursuant to 10 CFR Part 50. The license authorizes the operation of Indian Point 3 (facility) in accordance with the conditions specified therein. The facility is located on the Licensee's site in Buchanan, New York.

On March 10, 1993, the NRC, Region I, received information from NYPA that Mr. Bolton had attempted to substitute a "cold" [surrogate] urine sample during random Fitness-for-Duty (FFD) testing required by NRC regulations, that a subsequent witnessed sample provided by Mr. Bolton had tested positive for marijuana, that Mr. Bolton had been referred to the Employee Assistance Program, and his authorization for access to the Indian Point 3 facility had been suspended. In response to this information, NRC initiated an investigation by the office of Investigations (OI) of this matter. The investigation established that: 
-2 -

1. When called for a FFD test on March 9, 1993, Mr. Bolton knowingly submitted a surrogate urine sample which he had collected on a previous date and maintained for that purpose.

2. Mr. Bolton admitted that he provided surrogate urine samples in the past when selected for FFD testing in order to avoid detection of the presence of illegal substances.

On October 6, 1995, a Demand for Information (DFI) was issued to Mr. Bolton based on the findings of the OI investigation. The DFI indicated that Mr. Bolton had engaged in deliberate misconduct in violation of 10 CFR $50.5(a)(2)$, in that he provided to the facility licensee information which he knew to be inaccurate in some respect material to the NRC. Mr. Bolton's actions also constituted a violation of 10 CFR $50.5(a)(1)$ in that he deliberately provided a urine sample that he knew to be inaccurate and which, but for detection, would have caused the Licensee to be in violation of 10 CFR 50.9 , "Completeness and accuracy of information."

The DFI requested that $\mathrm{Mr}$. Bolton provide a response, within 30 days from the date of the DFI, that would: (A) Identify whether he currently is employed by any company subject to MRC regulation, and if so, describe in what capacity; and (B) Describe why the MRC should have confidence that Mr. Bolton will meet NRC requirements to provide complete and accurate information to the NRC and its licensees in the future. 
The DFI further stated that, if Mr. Bolton did not respond as specified, the NRC would proceed on the basis of available information and could take other actions as necessary to ensure compliance with regulatory requirements. Although a response to the DFI was due on November 6, 1995, as of the date of this Order, Mr. Bolton has not responded.

Based on the above, it appears that Mr. Bolton, an employee of the Licensee at the time of the incident, engaged in deliberate misconduct in violation of 10 CFR 50.5(a)(2), in that he submitted to the Licensee information which he knew to be inaccurate in some respect material to the NRC, and 10 CFR $50.5(a)(1)$, in that he deliberately provided a urine sample that he knew to be inaccurate and which, but for detection, would have caused the facility licensee to be in violation of 10 CFR 50.9.

The NRC must be able to rely on its Licensees and their employees to comply with NRC requirements, including the requirement to provide information and maintain records that are complete and accurate in all material respects. Mr. Bolton's actions in using illegal drugs and attempting to circumvent FFD requirements have ratsed serious doubt as to whether he can be relied upon to comply with NRC requirements and to provide complete and accurate information to the NRC and its Licensees. Although a DFI was issued on October 6, 1995 , which provided Mr. Bolton an opportunity to describe why the MRC should have 
confidence that he will meet NRC requirements to provide complete and accurate information to the NRC and its Licensees in the future, Mr. Bolton has not responded to the DFI.

Consequently, I lack the requisite reasonable assurance that: (1) Mr. Bolton will conduct any NRC-licensed activities in compliance with the Commission's requirements; and (2) that the health and safety of the public will be protected with Mr. Bolton granted unescorted access to NRC- licensed facilities at this time. Therefore, I find that the public health, safety, and interest require that $\mathrm{Mr}$. Bolton be prohibited from seeking unescorted access to NRC-licensed facilities for five years from the date of his termination of unescorted access by NYPA on March 9, 1993. Furthermore, pursuant to 10 CFR 2.202, I find that the significance of the misconduct described above is such that the public health, safety, and interest require that this Order be immediately effective.

Accordingly, pursuant to sections 103,161b,161i, 1610,182, and 186 of the Atomic Energy Act of 1954, as amended, and the Commission's regulations in 10 CFR 2.202 and 10 CFR 50.5, IT IS HEREBY ORDERED, EFFECTIVE IMMEDIATELY, THAT:

Mr. Bolton is prohibited for five years from the date of his termination of unescorted access by NYPA on March 9, 1993, from seeking unescorted access to facilities licensed by the NRC. 
The Director, OE, may, in writing, relax or rescind any of the above conditions upon demonstration by Mr. Bolton of good cause.

In accordance with 10 CFR 2.202, Mr. Bolton must, and any other person adversely affected by this Order may, submit an answer to this Order, and may request a hearing on this Order, within 20 days of the date of this Order. Where good cause is shown, consideration will be given to extending the time to request a hearing. A request for extension of time must be made in writing to the Director, Office of Enforcement, U.S. Nuclear Regulatory Commission, Washington, D. C. 20555, and include a statement of good cause for the extension. The answer may consent to this Order. Unless the answer consents to this Order, the answer shall, in writing and under oath or affirmation, specifically admit or deny each allegation or charge made in this Order and shall set forth the matters of fact and law on which Mr. Bolton or other person adversely affected relies and the reasons as to why the order should not have been issued. Any answer or request for a hearing shall be submitted to the Secretary, U.S. Nuclear Regulatory Commission, Attn: Chief, Docketing and Service Section, Mashington, DC 20555. Copies also shall be sent to the Director, Office of Enforcement, U.S. Nuclear Regulatory Commission, Washington, OC 20555, to the Assistant General Counsel for Hearings and Enforcement at the same address, to the Regional Administrator, NRC Region I, 475 Allendale Road, King of Prussia, Pennsylvania 19406, and to Mr. Bolton if the answer or hearing request is by a person other than Mr. Bolton. If a person other than Mr. Bolton requests a hearing, that person shall set forth 
with particularity the manner in which his interest is adversely affected by this order and shall address the criteria set forth in 10 CFR 2.714(d).

If a hearing is requested by Mr. Bolton or a person whose interest is adversely affected, the Commission will issue an Order designating the time and place of any hearing. If a hearing is held, the issue to be considered at such hearing shall be whether this Order should be sustained.

Pursuant to 10 CFR $2.202(\mathrm{C})(2)(i)$, Mr. Bolton, or any other person adversely affected by this Order, may, in addition to demanding a hearing, at the time the answer is filed or sooner, move the presiding officer to set aside the " immediate effectiveness of the Order on the ground that the Order, including the need for immediate effectiveness, is not based on adequate evidence but on mere suspicion, unfounded allegations, or error.

In the absence of any request for hearing, or written approval of an extension of time in which to request a hearing, the provisions specified in Section IV above shall be final 20 days from the date of this Order without further order or proceedings. AN ANSWER OR A REQUEST FOR HEARING SHALL NOT STAY THE IMMEDIATE EFFECTIVENESS OF THIS ORDER.

FOR THE NUCLEAR REGULATORY COMMISSION

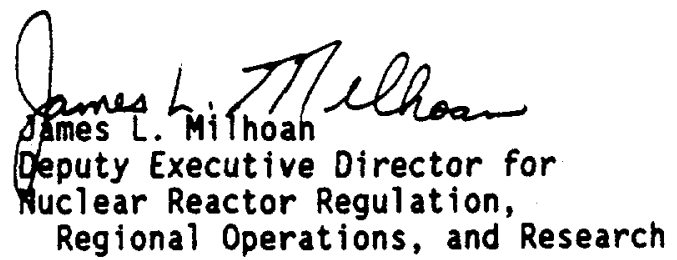

Dated at Rockville, Maryland this 23 rd day of February 1996 


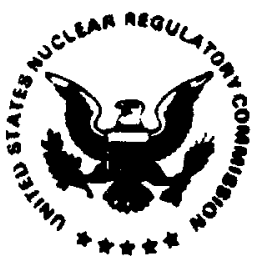

\author{
UNITED STATES
}

NUCLEAR REGULATORY COMMISSION

WAsHineton, o.c. 2asom

\title{
IN 14 1994
}

\section{IA $94-015$}

Mr. John W. Boomer

ADDRESS DELETED

Dear Mr. Boomer:

SUBJECT: OROER PROHIBITIMG INVOLVEMENT IM MRC-LICEMSED ACTIVITIES (EFFECTIVE IMAEDIATELY)

The enclosed Order Prohiblting Involveant In MRC-Licensed Activities (Effective Imediately) is being issued as a consequence of your del iberate violation of 10 CFR $35.70(e)$ and 10 CFR 30.10 while President of Chesapeake Imaging Center, Chesapeake, West Virginta. Based on an investigat ion conducted by the MRC's Office of Investigations (OI), the NRC staff has determined that you doliberately violated NRC requireaents by falling to conduct weekly surveys for removabie contanination: After being advised by your staff of the regulatory requireant and the fact that instrumentation was not avaliable to perform the required survey, you falled to provide the required instruentation and pormitted 1icensed activities to continue. A copy of the synopsis of the of investigation was provided to you by letter dated December 2, 1993, and again by letter dated February 28, 1994. An enforcement conference by telephone was held with you on March 8, 1994. The sumary of this conference was sent to you on March 16, 1994.

Such conduct is unacceptable to the MRC. Therefore, after consultation with the Comission, I have been authorized to issue the enclosed Order Prohtbiting Involvement In MRC-Licensed Activities (Effective Imnediately). Failurs to comply with the provistons of this order may result in civil or criminal sanctions.

Questions concerning this Order should be addressed to Mr. James Lteberman, Director, Office of Enforcenent, tho can be reached at (301) 504-2741. 
In accordance with 10 CFR 2.790 of the NRC's "Rules of Practice," a copy of this letter with your address deleted and the enclosure will be placed in the NRC's Public Document Room.

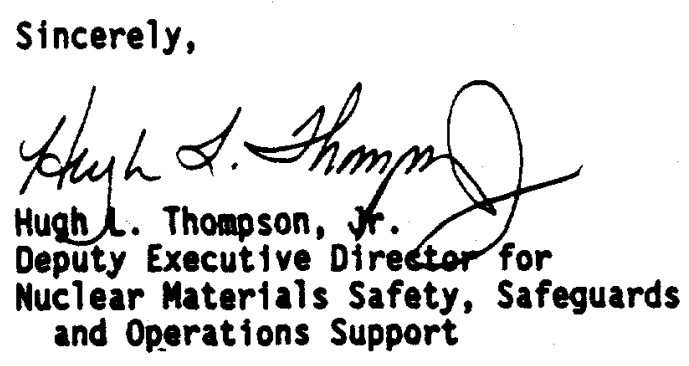

Enclosure: Order Prohibiting Involvewent In MRC-Llcensed Activities (Effective Imadiately)

ce w/enclosure

Public Document Room

State of West Virginia, Director Departwent of Public Health

State of Callfornia, Oirector

All States Department of Public Health

Chesapeake Inaging Center, Inc.

11940 MacCorkie Avenue

Chesapeake, Mest Virginia 25315 
UNITED STATES

NUCLEAR REGULATORY COMISSIOH

In the Matter of

IA $94-015$

John W. Boomer

ADDRESS DELETED

\{

ORDER PROHIBITING INVOLVEMENT IN MRC-LICENSED ACTIVITIES

(EFFECTIYE IMNEDIATELY)

\section{I}

John H. Boomer has been a nuclear medicine technologist since 1972 . On February 11, 1993, Mr. Boomer, as the President of Chesapeake Imaging Center, Inc. (CIC or Licensee) applied for an MRC 1icense. On March 23, 1993 Materials License No. 47-25238-01 was issued to CIC by the Nuclear Regulatory Comisston (MRC or Comisston) pursuant to 10 CFR Parts 30 and 35 . The Ifcense authorized the possesston and use of radtopharaceuticals for nuclear medicine activities in accordance with the conditions specified therein. The Itcense was terminated this date.

\section{II}

On July 30, 1993, the MRC conducted an initial inspection of CIC at its facility located in Chesapeake, West Virginia. As a result of the inspection, multiple violations of MiC requirements were identified. One specific violation Identified involved the fallure to perfora weekly surveys for removable contanination in the nuclear medicine department between March 24 and July 30, 1993. As a result of this inspection, a Notice of Violation is being issued contemporaneously with this order. 
Between August 3 and September 30, 1993, an investigation was conducted by the MRC Office of Investigations (OI) to determine if certain violations identifled during the July 30, 1993, inspection were the result of deliberate misconduct. Based on investigative findings, the NRC staff concludes that Mr. Boomer deliberately caused CIC to violate the requirement to perform the weekly contanination surveys, after being advised by the CIC facility Manager and CIC techntcal consultant that such surveys were required. Mr. Boomer was aware of the MRC requirement to perform weekly contanination surveys, yet delfberately falled to meet the requirement in violation of 10 CFR $35.70(e)$ and 10 CFR 30.10.

A transcribed telephone enforcesent conference between the MRC staff and Mr. Boomer was held on March 8, 1994. Mr. Boomer indicated during the enforceant conference that he had signiflcant difficulties in obtaining the funds from investors and did not recognize the severity of the noncompliance but rather focused on the needs of patients traveling alles to obtain the studies. Mr. Boomer also stated during the enforcement conference that he did accept responsibility for not obtaining the equipment in a more timely fashion and for not notifying MRC and indicated that he would exercise better judgment In the future. From the discussions at the enforcement conference, the staff believes an ondar to renove Mr. Boomer from involvenent in MRC-licensed activities is warranted based on (1) the deliberate noncompliance with the NRC's weekly survey requirement, (2) the fundamental lack of assurance that he will in the future comply with Comission requtrements, (3) his position as Prestdent, (4) his approximate 20 years expertence in MRC-11censed activities, 
and (5) his decision to continue operations although he knew he was not in compliance with the weekly survey requirement.

\section{III}

Based on the above, Mr. Boomer engaged in deliberate misconduct which caused the licensee to be in violation of 10 CFR 35.70(e). The NRC wust be able to rely on the Licensee and its employees to comply with MRC requirements, including the requitement to perform weekly contanination surveys. Compl lance with the NRC requirement to perform weekly contanination surveys is necessary to protect members of the public as well as Licensee employees from unnecessary radiation exposure that could result from undetected radioactive contamination. Performance of weekly contanination surveys is an important safety requirement intended to prevent radioactive contanination of patients, employees and other members of the public. Mr. Boomer's deliberate actions in causing the Licensee to violate these requirements have ratsed serfous doubts as to whether he can be relied on to be involved in MRC-licensed activities.

Consequently, I lack the requisite reasonable assurance that licensed activities can be conducted in compliance with the comission's requirements and that the health and safety of the public will be protected if Mr. Boomer were peraitted at this tice to be involved in MRC-11censed activities. Therefore, the public health, safety and interest require that Mr. Boomer be prohibited from any involveant in MRC-licensed activities for a period of three years from the date of this order, and if he is currently involved with another licensee in MRC-1tcensed activities, he must imediately cease such 
activities, and inform the NRC of the name, address and telephone number of the employer, and provide a copy of this order to the employer. During this period Mr. Boomer also shall be requitred to provide a copy of this order to any prospective employer who engages in MRC-licensed activities prior to the time that Mr. Boomer accepts employwent with such prospective employor. The purpose of this notice is so that any prospective employer is aware of Mr. Boomer's prohibition from eagaging in MRC-licensed activities. Additionally, Mr. Boomer is required to notify the MRC of his first employment in NRC-licensed activities following the prohibition period. Furthermore, pursuant to 10 CFR 2.202, I find that the significance of Mr. Bocmer's conduct described above is such that the public health, safety and interest require that this Order be inodiately effective.

\section{IV}

Accordingly, pursuant to sections 81, 161b, 161c, 1611, 1610, 182 and 186 of the Atomic Energy Act of 1954, as asended, and the Comaission's regulations in 10 CFR 2.202, 10 CFR 30.10, and 10 CFR 150.20, IT IS HEREBY ORDERED, EFFECTIVE IMEDEIATELY, THAT:

1. Mr. John M. Bocair is prohibited for three years from the date of this Order free any involveanent in MRC-licensed activities. MRC-1 licensed activities are those activities which are conducted pursuant to a specific or general license issued by the MRC, including, but not liaited to, those activities of Agreement State Ifcensees conducted pursuant to the authority granted by 10 CFR 150.20. 
2. For a period of three years from the date of this Order, Mr. John W. Boomer shall provide a copy of this Order to any prospective employer who engages in MRC-1icensed activities (as defined in 1 above) prior to his acceptance of employment with such prospective employer. The purpose of this requirement is to ensure that the employer is aware of $\mathrm{Mr}$. Boomer's prohibition from engaging in MRC-licensed activitfes.

3. The first tian Mr. Boomer is employed in MRC-licensed activities following the three year prohibition, he shall notify the Regional Adainistrator, NRC Region II, 101 Martetta Street, MA, Sulte 2900, At lanta, Georgla 30323, at least five days prior to the performance- of licensed activities or his being exployed to perform NRC-11censed activities (as described in 1 above). The notice shall include the nawe, address, and telephone number of the MRC or Agreewent State licensee and the location where the licensed activities will be performed.

4. If Mr. Boower is currently involved in MRC-licensed activities at an employer or entity, Mr. Boomer shall, in accordance with Paragraph 1 above, inadiately cease such activities and provide notice within 20 days of the date of this Order to the Oirector; Office of Enforcement, U. S. Muclear Regulatory Comission, Washington, DC 20555 of the name, address and telephone number of the employer or entity where the licensed activities are baing conducted. Further, Mr. Boomer shall provide a copy of this Order to his employer if his employer is engaged in MRC-licensed activities. 
The Director, Office of Enforcement, may, in writing, relax or rescind any of the above conditions upon a showing by Mr. Boomer of good cause.

\section{V}

In accordance with 10 CFR 2.202, Mr. Boomer must, and any other person adversely affected by this Order may, subait- an answer to this Order, and may request a hearing on this Order, within 20 days of the date of this Order. The answer may consent to this Order. Unless the answer consents to this Order, the answer shall, in writing and under oath or afftration, specifically adatt or deny each allegation or charge made in this Order and shall set forth the matters of fact and law on which Mr. Boomer or any other person adversely affected relles and the reasons as to why the Order should not have been issued. Any answer or request for a hearing shall be subaltted to the Secretary, U.S. Nuclear Regulatory Comission, Attn: Chief, Docketing and Service Section, Washington, OC 20555. Coptes also shall be sent to the Director, Office of Enforcement, U. S. Nuclear Regulatory Comission, Washington, DC 20555; to the Assistant General Counsel for Hearings and Enforcement at the sam address, to the Regional Administrator, NRC Region II, 101 Marietta Streat, M. M., Sulte 2900, Atlanta, Georgia 30323, and to Mr. Boowar if the answar or hearing request is by a person other than Mr. Boowar. If a parson other than Mr. Boomer requests a hearing, that person shall set forth with particularity the manner in which his or her interest is adversely affected by this Order and shall address the criteria set forth in 10 CFR $2.714(d)$. 
If a hearing is requested by Mr. Boomer or a person whose interest is adversely affected, the Comission will issue an Order designating the time and place of any hearing. If a hearing is held, the issue to be considered at such hearing shall be whether this Order should be sustained.

Pursuant to 10 CFR 2.202(C)(2)(1), Mr. Boomer, or any other person adversely affected by this Order, any, In addition to-deanding a hearing, at the time the answor is filed or sooner, wove the presiding officer to set astde the insediate effectiveness of the Order on the ground that the Order, Including the need for inadiate effectiveness, is not based on adequate evidence but on mere suspicton, unfounded allegations, or error.

In the absence of any request for hearing, the provistons specified in Section IV above shall be final 20 days from the date of this Order without further Order or processing. AN AUSUER OR A REqUEST FOR HEARING SHALL MOT STAY THE. IMEDIATE EFFECTIVENESS OF THIS ORDER.

FOR THE MUCLEAR REGULATORY COMISSION

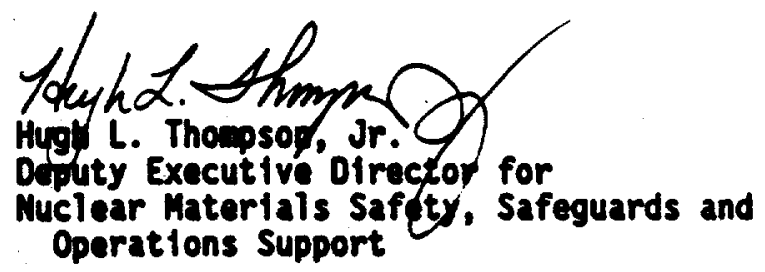

Dated at Reelville, Maryland this /4thay of July 1994 


\section{UNITED STATES \\ NUCLEAR REGULATORY COMMISSION \\ WASH:NGTON. D.C. 206500001}

$$
\text { Yay 4, } 1993
$$

IA $93-001$

Mr. Richard J. Gardeckj.

(Address)

Dear sir:

SUBJECT: ORDER PROHIBITING INVOLVEMENT IN CERTAIN NRC-LICENSED ACTIVITIES (EFFECTIVE IMAEDIATELY)

The enclosed order is being issued because of your violations of 10 CFR 40.10 of the Commission's regulations as described in the order.

Failure to comply with the provisions of this order may result in civil or criminal sanctions.

Questions concerning this order should be addressed to Mr. James Lieberman, Director, Office of Enforcement, who can be reached at (301) 504-2741.

In accordance with 10 CFR 2.790 of the NRC's "Rules of Practice", a copy of this letter and the enclosures will be placed in the NRC's Public Document Roos.

sincerely,

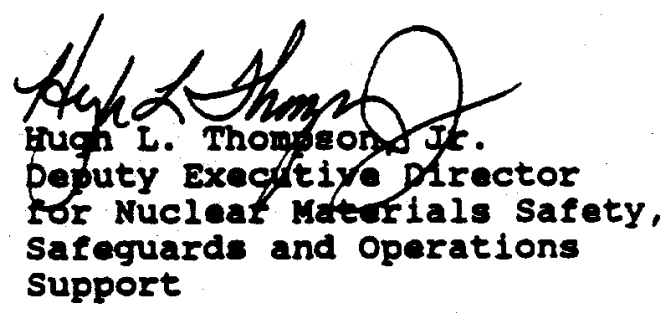

Enclosure: a stated

cc: Allied-signal, Inc.

All Agreement states

SECY 
NUCLEAR REGULATORY COMMISSION

In the Matter of

Richard J. Gardecki

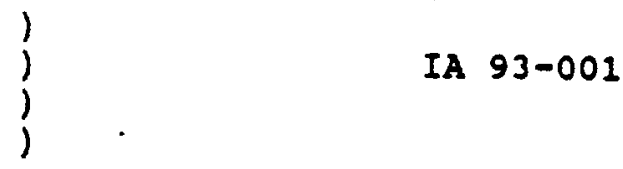

ORDER PROHIBITING INVOLVEMENT IN CERTAIN

NRC-LICENSED ACTIVITIES

(EFFECTIVE IMAEDIATELY)

I

Richard J. Gardecki was recently employed by Allied-signal, Inc., Metropolis, Illinois. Allied-signal, Inc. (Licensee) holds License No. SUB-526 issued by the Nuclear Regulatory Commisston. (NRC or Commission) pursuant to $10 \mathrm{CFR}$ Part 40 . The 1icense authorizes possession and conversion of uranium in accordance with the conditions specilied therein. kr. Gardecki was aployed by the Iicensee Erom about June 1991 through Decomber 1992 in the position of Assistant Health Physicist, with responsibilities involving compliance with IRC requirements for radiation protection. Under the Ilcensed's organization and qualifications requirements, as epecified in Iicense Condition No. 9, an Assistant Health Physicist is required to hold a bachelor's degree. Fallure to have a bachelor's degree holder in that position constitutes a violation of Iicense Condition No. 9.

II

On October 5-7, 1992, an inspection was conducted at the License's facility at Motropolis, Illinois, as a result of concerne raised within the NRC staff as to the education and experience of Richard J. Gardecki. As a result of information 
developed in that inspection, an investigation was conducted in November and December 1992 by the office of Investigations (OI). The inspection and investigation revealed that Mr. Gardecki intermittently took courses at the University of Delaware between 1962 and 1967 and in 1978, but did not accumulate sufficient credits to earn a bachelor's degree. While employed at the University of Delaware, between 1977 and 1981, Mr. Gardecki prepared a transcript that falsely reflected sufficient hours of credit at that university to entitle hin to a Bachelor of science degree.

Mr. Gardecki subsequently used the salse transcript to obtain employment at the Univeraity of Nebraska in about 1983, at Westinghouse Radiological services Division in about 1985, at Environmental Testing Inc., in 1988, and at the Licensee in about June 1991. In each of these positions, $\mathrm{kr}$. Gardecki was involved in activities licensed by the NRC or an Agreenent state, pursuant to an agreement with the NRC under section 274 of the Atomic Energy Act of 1954, as amended.

In addition, Ir. Gardecki obtained employment as a Radiation Specialist at the IRC in 1987 by submitting a standard Form 171 (SF171), Application for Federal Employment, which contained the same false information rogarding a bachelor's degree at the University of Delaware. He was allowed to resign his NRC employment following 1dentiflcation of the falsehood. Also, 
during the or investigation, he admitted that he had provided false information to the NRC regarding prior employment by General Dynamics in Denver, Colorado.

Further, in a transcribed sworn statement on December 1, 1992, Mr. Gardecki deliberately provided false information to oI investigators when he stated that he graduated from the University of Delaware in 1961. When asked about the University records indicating that he had not received a degree, $\mathrm{kr}$. Gardecki fabricated a story about the University having mixed his record with that of his brother. He also deliberately provided false information as to the accuracy of a University of Delaware transcript that he had submitted to the Licensee. In a transcribed, sworn statenent to or investigators on December 14 , 1992, Mr. Gardecki admitted that he had provided false information in his sworn statements previously given to or investigators on December 1, 1992 concerning his academic record and applications for enployment.

III

Based on the above, kr. Gardecki engaged in deliberate misconduct, which through his employment (from about June 1991 through December 1992) in a position with educational requirements that Mr. Gardecki did not meet, caused the Iicensee to be in violation of the organization and qualifications 
requirements of License condition No. 9. This is a violation of 10 CFR 40.10. Mr. Gardecki also deliberately provided to NRC investigators information that he knew to be inaccurate and was in some respects material to the NRC which also constitutes a violation of 10 CFR 40.10. As an Assistant Health Physicist for the Licensee, Mr. Gardecki was responsible for performance of required surveys and kẹping of required records, all of which provide evidence of compliance with commission requirements. The NRC must be able to rely on the Licensee and its employees to comply with NRC requirements, including the requirement to provide information and maintain records that are complete and accurate in all material respects. Mr. Gardeckl's deliberate actions in causing this Licensee to be in violation of License Condition No. 9, a violation of $10 \mathrm{CFR} 40.10$, and his violation of $10 \mathrm{CFR} 40.10$ caused by his deliberate misrepresentations to the NRC have raised serious doubt as to whether he can be relied upon to comply with NRC requirements and to provide complete and accurate information to the MRC or to an employer. Mr. Gardecki's misconduct (repeated on several occasions over several years with several aployers) caused this Iicensee to violate a Commission requirenent; and his false statements to Commission officlals denonstrate conduct that cannot and will not be tolerated.

Consequently, I lack the requisite reasonable assurance that licensed activities in MRC jurisdiction can be conducted in 
compliance with the Commission's requirements and that the health and safety of the public will be protected, if Mr. Gardecki were permitted at this time to be named as a Radiation safety officer (RSO) on an NRC license or permitted to supervise licensed activities (i.e., being responsible in any respect for any individual's performance of any licensed activities) for an NRC licensee or an Agreement state licensee while conducting licensed activities in NRC jurisdiction pursuant to $10 \mathrm{CFR} 150.20$. Therefore, the public health, safety and interest require that Mr. Gardecki be prohibited from being named on an MRC license as an RSO or from supervising licensed activities (1.e., being responsible in any respect for any individual's performance of any Iicensed activities) for an NRC licensee or an Agreement state licensee while conducting licensed activities in NRC jurisdiction pursuant to $10 \mathrm{CFR} 150.20$ for a period of five years from the date of this order. In addition, for the same period, Mr. Gardecki is required to give notice of the existence of this order to a prospective employer engaged in licensed activities, described below (section IV, paragraph 2), to assure that such employer is aware of Mr. Gardecki's previous history. Mr. Gardecki is also reguired to notify the NRC of his employment by any person engaged in licensed activities, described below (Section IV, paragraph 2), so that appropriate inspections can be performed. Furthermore, pursuant to $10 \mathrm{CFR} 2.202$, I find that the significance of the conduct described above is such that the 
public health, safety and interest require that this order be immediately effective.

Accordingly, pursuant to sections 61, 81, 103, 161b, 1611, 182 and 186 of the Atomic Energy Act of 1954, as amended, and the Commission's regulations in 10 CFR $2.202,10 \mathrm{CFR} 40.10$, and 10 CFR 150.20, IT IS HEREBY ORDERED, EFFECTIVE IYAEDIATELY, THAT:

1. Richard J. Gardecki is prohibited for tive years from the date of this order from being named on an NRC Iicense as a Radiation Safety Officer or from supervising licensed activities (i.e., being responsible in any respect for any individual's performance of any licensed activities) for an NRC licensee or an agreement state licensee while conducting licensed activities in NRC jurisdiction pursuant to $10 \mathrm{CFR} 150.20$.

2. Should Richard J. Gardecki seek employment with any person engaged in licensed activities during the five year perlod from the date of this order, Mr. Gardecki shall provide a copy of this order to such person at the time Mr. Gardecki is soliciting or negotiating employment so that the person is aware of the order prior to making an employment decision. For the 
purposes of this paragraph licensed activities include licensed activities of 1) an NRC licensee, 21 an Agreement state licensee conducting licensed activities in NRC jurisdiction pursuant to $10 \mathrm{CFR} 150.20$, and 3) an Agreement state 1 icensee involved in distribution of products that are subject to NRC jurisdiction.

3. For a five year period from the date of this order, Richard J. Gardeckl shall provide notice to the Director, office of Enforcement, U.S. Nuclear Regulatory Commission, Washington, DC 20555, of the name, address, and telephone number of the employer, within 72 hours of his acceptance of an employment offer, involving licensed activities described in paragraph 2, above.

The Director, office of Enforcement, may, in writing, relax or rescind any of the above conditions upon demonstration by Mr. Gardecki of good cause.

In accordance with 10 CFR 2.202, Richard J. Gardecki must, and any other person adversely affected by this order may, submit an answer to this order, and may request a hearing on this order, within 20 days of the date of this order. The answer may consent to this order. Unless the answer consents to this order, the 
answer shall, in writing and under oath or affirmation, specifically admit or deny each allegation or charge made in this order and shall set forth the matters of fact and law on which Richard J. Gardecki or other person adversely affected relies and the reasons as to why the order should not have been issued. Any answer or request for a hearing shall be submitted to the Secretary, U.S. Nuclear Regulatory Commission, Attn: Chief, Docketing and Service Section, Washington, DC 20555. Copies also shall be sent to the Director, office of Enforcement, U.S. Nuclear Regulatory Comission, Washington, DC 20555, to the Assistant General Counsel for Hearings and Enforcement at thesame address, to the Regional Administrator, NRC Region III, 799 Roosevelt Rd., Glen Eliyn, IL 60137, and to Richard J. Gardecki, if the answer or hearing request is by a person other than Richard J. Gardecki. If a person other than Richard J. Gardecki requests a hearing, that person shall set forth with particularity the manner in which his or her interest is adversely affected by this order and shall address the criteria set forth in $10 \mathrm{CrR} 2.714$ (d).

If a hearing is requested by Richard J. Gardecki or a person whose interest is adversely affected, the Commission will issue an order deelgnating the time and place of any hearing. If a hearing is held, the issue to be considered at such hearing shall be whether this order should be sustained. 
Pursuant to $10 \mathrm{CFR} 2.202$ (c)(2)(i), Richard J. Gardecki, or any other person adversely affected by this order, may, in addition to demanding a hearing, at the time the answer is filed or sooner, move the presiding officer to set aside the immediate effectiveness of the order on the ground that the order, including the need for immediate effectiveness, is not based on adequate evidence but on mere suspicion, unfounded allegations, or error.

In the absence of any request for hearing, the provisions specified in section IV above shall be final 20 days from the date of this order without further order or proceedings. AN ANSWER OR A REQUEST FOR HEARING SHALC NOT STAY THE IMACDIATE EFFECTIVENESS OF THIS ORDER.

FOR THE NUCLERR REGULATORY COMIISSION

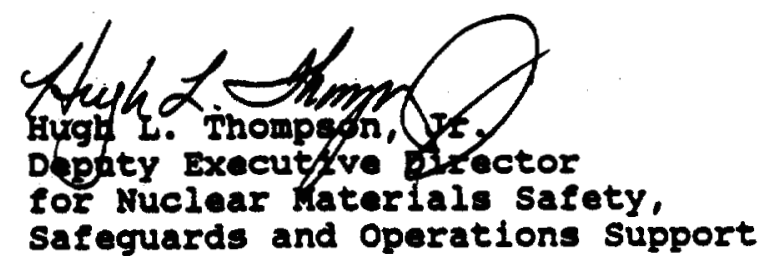

Dated at Rockville, Maryland

this of th day of ray 1993 


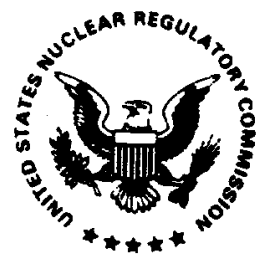

\section{UNITED STATES}

\section{NUCLEAR REGULATORY COMMISSION}

WASHINGTON, D.C. 2056-0001

April 19, 1996

IA $96-020$

Mr. Juan Guzman

HONE ADDRESS DELETED

UNDER 2.790

SUBJECT: ORDER PROHIBITING UNESCORTED ACCESS OR INVOLVEMENT IN NRC-LICENSED ACTIVITIES (EFFECTIVE IMMEDIATELY)

Dear Mr. Guzman:

The enclosed Order is being issued to you as a result of an NRC investigation by the Office of Investigations (OI) which, in part, concluded that you intentionally made false statements in your application for a security clearance at the Calvert Cliffs Nuclear Power Plant, and deliberately submitted false information to Baltimore Gas \& Electric Company (BG\&E). As noted in the Demand for Information that the NRC issued to you on January 2, 1996, BG\&E revoked your unescorted access authorization for the Calvert Cliffs facility, and you were denied unescorted access to the protected area in October 1994 after BG\&E became aware, through an investigation by the Immigration and Naturalization Service and State Department, that you were an illegal alien who had received a passport under another name.

Your unescorted access to the plant initially had been granted by BGQE on February 23, 1993, based, in part, on your submittal of a "green card" and social security card during the initial interview process, both of which were represented as authentic when, in fact, they were not. In addition, when questioned by the licensee regarding an arrest record revealed during FBI fingerprint checks, you repeatedly denied that the arrest record belonged to you. Your falsification of NRC-required background information, as well as your subsequent denials to the licensee, constitute a significant regulatory concern.

The NRC regulations in 10 CFR 73.56 and 73.57 were established, in part, to provide high assurance that individuals granted unescorted access to nuclear power plants are trustworthy and reliable. Your actions in this matter did not demonstrate trustworthiness and constitute a violation of the requirements of 10 CFR 50.5, "Deliberate Misconduct," because you del iberately submitted to BG\&E information you knew to be incomplete or inaccurate in some respect material to the NRC. Following your termination from employment at the Calvert Cliffs plant, the NRC sent you a Demand for Information (DFI) on January 2, 1996 which requested that you provide the NRC a response which: (1) identifies whether you currently are employed by any company subject to NRC regulation, and if so, in what capacity; (2) describes why the NRC shouid permit you to be involved in licensed activities in the future or have 
confidence that you will comply with NRC requirements if currently employed in an NRC-regulated activity, including requirements to provide complete and accurate information; and (3) explains why the NRC should not conclude that your actions in providing false information to the licensee were done deliberately.

In your February 7, 1996 response to the DFI, you indicated that you were not currently employed by any company subject to NRC regulation; at no time were you cited for a procedure or safety violation while employed at Calvert Cliffs; and that the sole reason you did not disclose that you were an illegal alien was your fear of deportation. You also admitted that you did deliberately, but without malice or intent, deceive the licensee about your work background and experience, but did so solely out of fear of deportation; pointed out an inaccuracy in the DFI in that while you did apply for a passport under another name, you never pursued the document; requested that, if the NRC decided to prohibit you from working for an NRC i icensee, consideration be given to the 15 months that had eliapsed since your termination; and noted that the Immigration and Naturalization Service granted you legal resident status in the United States in January 1996.

Notwithstanding your response, the NRC has determined that to ensure compliance with regulatory requirements, the enclosed Immediately Effective Order is appropriate, to prohibit you for a period of five years from seeking unescorted access to any NRC-licensed facility and prohibit your involvement in NRC-licensed activities, for the reasons set forth in the enclosure.

Pursuant to Section 223 of the Atomic Energy Act of 1954, as amended, any person who willfully violates, attempts to violate, or conspires to violate, any provision of this Order shall be subject to criminal prosecution as set forth in that section.

Please note that you are required to respond to this order, and should follow the instructions specified in Section $v$ of the order when preparing your response. Failure to comply with the provisions of this order may result in civil or criminal sanctions. Questions concerning this order should be addressed to Mr. James Lteberman, Oirector, Office of Enforcement, who may be reached at (301) 415-2741.

A copy of this letter and Order are being sent to Mr. Charles H. Cruse, VicePresident-Niclear Energy, Calvert Cliffs. BG\&E is not required to provide a response to the Order, but may do so, if it desires, within 30 days under oath or affirmation. 
In accordance with 10 CFR 2.790 of the NRC's "Rules of Practice," a copy of this letter, its enclosures, and your response will be placed in the NRC Public Document Room (PDR).

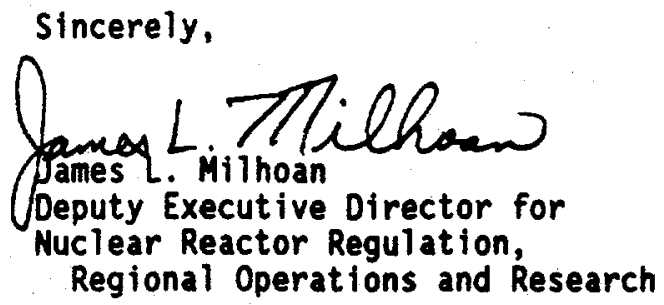

Docket Nos. 50-317; 50-318

License Nos. DPR-53; OPR-69

Enclosure: Order Prohibiting Unescorted Access

or Involvement in NRC-licensed activities

(Effective Immediately)

cc w/encl:

Charles H. Cruse

Vice President - Nuclear Energy

Baltimore Gas \& Electric Company 
UNITED STATES

NUCLEAR REGULATORY COMMISSION

In the Matter of

MR. JUAN GUZMAN

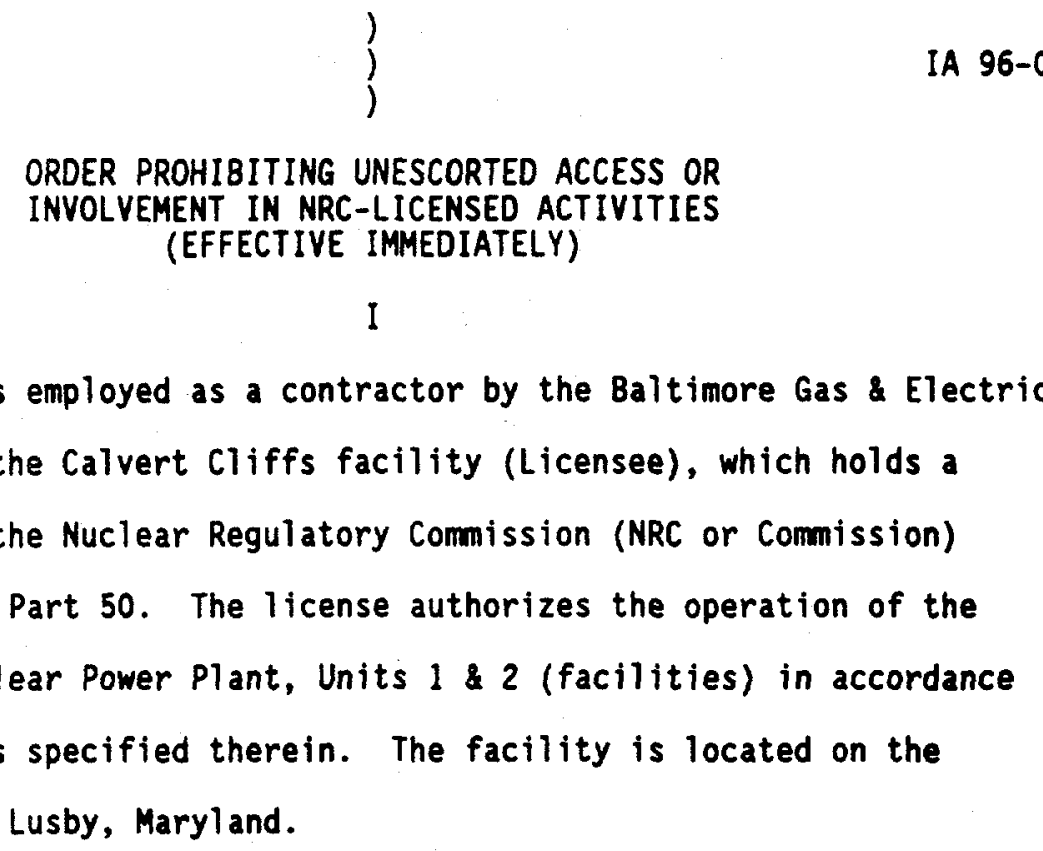

In a Licensee Event Report issued by BGaE on November 16, 1994, the NRC received information from BG\&E indicating that BG\&E had revoked Mr. Guzman's unescorted access authorization and removed $h$ im from the protected area in October 1994 after it became aware through an investigation by the Immigration and Maturalization Service and State Department, that Mr. Guzman was an illegal allen.

Mr. Guzman's unescorted access to the site initially had been granted by BG\&E on February 23, 1993 based, in part, on his submittal of a "green card" and social security card during the initial interview process, both of which were represented as authentic when, in fact, they were not. In addition, when 
questioned on prior occasions by the Licensee regarding an arrest record obtained as a result of fingerprints submitted to the FBI, Mr. Guzman repeatedly denied that the arrest record belonged to him, even though it did. Mr. Guzman's falsification of background information, combined with his subsequent denials to the Licensee, constitute a significant regulatory concern.

The NRC regulations in 10 CFR 73.56 and 73.57 were established, in part, to provide high assurance that individuals granted unescorted access are trustworthy and reliable. Mr. Guzman's actions in this matter did not demonstrate that trustworthiness, and constitute a violation of the requirements of 10 CFR 50.5, "Deliberate Misconduct," because Mr. Guzman deliberately submitted to the Licensee information that he knew was incomplete or inaccurate in some respect material to the NRC.

Although Mr. Guzman was terminated from employment at Calvert Cliffs in October 1994, his actions in this matter raise serious concerns as to whether he can be relied upon to comply with NRC requirements. Therefore, pursuant to sections 161c, 1610, 182 and 186 of the Atomic Energy Act of 1954, as amended, and the Commission's regulations in 10 CFR 2.204, in order for the Commission to determine whether further enforcement action should be taken against Mr. Guzman to ensure compliance with NRC regulatory requirements, the NRC sent him a Demand for Information (DFI) on January 2, 1996. The DFI required Mr. Guzman to provide the NRC a response that: (1) identifies whether he is 
currently employed by any company subject to NRC regulation and, if so, describes in what capacity; (2) describes why the NRC should permit him to be involved in licensed activities in the future or have confidence that he will comply with NRC requirements if currently employed in an NRC-regulated activity, including requirements to provide complete and accurate information; and (3) explains why the NRC should not conclude that his actions in providing false information to the Licensee were done deliberately.

In a letter dated February 7, 1996, Mr. Guzman responded to the OFI. In that response, Mr. Guzman stated that: (1) he was not currently employed by any company subject to NRC regulation; (2) at no time was he cited for a procedure or safety violation while employed at Calvert Cliffs; and (3) the sole reason he did not disclose that he was an illegal allen was his fear of deportation. He also admitted that he did deliberately, but without malice or intent, deceive the Licensee about his work background and experience, but did so solely out of fear of deportation; pointed out an inaccuracy in the DFI in that while he did apply for a passport under another name, he never pursued the document; requested that, if the NRC decided to prohibit him from working for an NRC licensee, consideration be given to the 15 months that had elapsed since his termination; and noted that the Immigration and Naturalization Service granted him legal resident status in the United States in January 1996. 
Notwithstanding his motives in providing false information to the Licensee, it is clear, as Mr. Guzman admitted in his response, that he provided false information to the Licensee, and did so deliberately. In doing so, Mr. Guzman engaged in deliberate misconduct in violation of 10 CFR $50.5(a)(2)$, in that he deliberately submitted to the Licensee information that he knew to be inaccurate in some respect material to the NRC. Such behavior cannot be tolerated by the NRC.

The NRC must be able to rely on its licensees and their employees, including contractor employees, to comply with NRC requirements, including the requirement to provide information that is complete and accurate in all material respects. Mr. Guzman's actions in knowingly falsifying background information and his identity in an attempt to avoid discovery and gain access to the Calvert $\mathrm{Cliffs}$ facility, and his false statements to Licensee officials when questioned about his background and identity, have raised serious doubt as to whether he can be relied upon to comply with NRC requirements and to provide complete and accurate information to the NRC and its licensees.

Consequently, I lack the requisite reasonable assurance that: (1) Mr. Guzman will conduct NRC-licensed activities in compliance with the Commission's requirements; and (2) the health and safety of the public will be protected if Mr. Guzman is granted unescorted access to NRC-licensed facilities at this time. Therefore, I find that the public health, safety, and interest require that Mr. Guzman be prohibited from involvement in NRC-licensed activities for 
five years from the date of the termination of his unescorted access by $8 G 2 E$ on October 18, 1994. Furthermore, pursuant to 10 CFR 2.202, I find that the significance of the misconduct described above is such that the public health, safety, and interest require that this Order be immediately effective.

\section{V}

Accordingly, pursuant to sections 103,161b,161i, 182, and 186 of the Atomic Energy Act of 1954, as amended, and the Commission's regulations in 10 CFR 2.202 and 10 CFR 50.5, IT IS HEREBY ORDERED, EFFECTIVE IMMEDIATELY, THAT:

A. For a five-year period from October 18, 1994, the date of the termination of his unescorted access by BG\&E, Mr. Juan Guzman is prohibited from engaging in NRC-licensed activities. For the purpose of this paragraph, NRC-licensed activities include licensed activities of: (1) an NRC licensee; (2) an Agreement State licensee conducting licensed activities in NRC jurisdiction pursuant to 10 CFR 150.20; and (3) an Agreement State licensee involved in distribution of products that are subject to NRC jurisdiction.

B. For a five-year period from October 18, 1994, the date of the termination of his unescorted access by BG\&E, Mr. Juan Guzman is prohibited from obtaining unescorted access at a NRC-licensed facility.

The Director, $O E$, may, in writing, relax or rescind any of the above conditions upon demonstration by Mr. Guzman of good cause. 
In accordance with 10 CFR 2.202, Mr. Guzman must, and any other person adversely affected by this Order may, submit an answer to this Order, and may request a hearing on this Order, within 20 days of the date of this Order. Where good cause is shown, consideration will be given to extending the time to request a hearing. A request for extension of time must be made in writing to the Director, Office of Enforcement, U. S. Nuclear Regulatory Commission, Washington, D. C. 20555, and include a statement of good cause for the extension. The answer may consent to this Order. Unless the answer consents to this Order, the answer shall, in writing and under oath or affirmation, specifically admit or deny each allegation or charge made in this Order and shall set forth the matters of fact and law on which Mr. Guzman or other person adversely affected relies and the reasons as to why the Order should not have been issued. Any answer or request for a hearing shall be submitted to the Secretary, U.S. Nuclear Regulatory Commission, Attn: Chief, Docketing and Service Section, Washington, OC 20555. Copies also shall be sent to the Director, Office of Enforcement, U.S. Nuclear Regulatory Commission, Washington, DC 20555, to the Assistant General Counsel for Hearings and Enforcement at the same address, to the Regional Administrator, NRC Region I, 475 Allendale Road, King of Prussia, Pennsylvania 19406, and to Mr. Guzman if the answer or hearing request is by a person other than Mr. Guzmian. If a person other than Mr. Guzman requests a hearing, that person shall set forth with particularity the manner in which his interest is adversely affected by this Order and shall address the criteria set forth in 10 CFR 2.714(d). 
If a hearing is requested by Mr. Guzman or a person whose interest is adversely affected, the Commission will issue an Order designating the time and place of any hearing. If a hearing is held, the issue to be considered at such hearing shall be whether this Order should be sustained.

Pursuant to 10 CFR 2.202(c)(2)(i), Mr. Guzman or any other person adversely affected by this Order may, in addition to demanding a hearing, at the time the answer is filed or sooner, move the presiding officer to set aside the immediate effectiveness of the Order on the ground that the Order, including the need for immediate effectiveness, is not based on adequate evidence but on mere suspicion, unfounded allegations, or error.

In the absence of any request for hearing, or written approval of an extension of time in which to request a hearing, the provisions specified in Section IV above shall be final 20 days from the date of this Order without further order or proceedings. AN ANSWER OR A REQUEST FOR HEARING SHALL NOT STAY THE IMMEDIATE EFFECTIVENESS OF THIS ORDER.

FOR THE NUCLEAR REGULATORY COMISSION

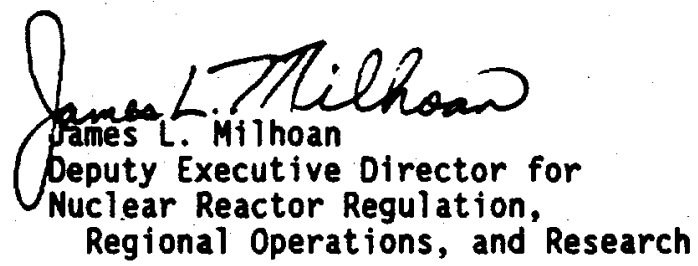

Dated at Rockville, Maryland this lath day of Aprit 1996 


\author{
UNITED STATES OF NMERICA \\ NUCLEAR REGULATORY COMISSION \\ ATOMIC SAFETY AND LICENSING BOARD \\ Before Administrative Judges: \\ G. Paul Bollwerk, III, Chairman \\ Dr. Charles N. Kelber \\ Dr. David R. Schink
}

LBP- $0-20$.

to is is 25

OF $\therefore$

DOir.

SERVED OCT 161996

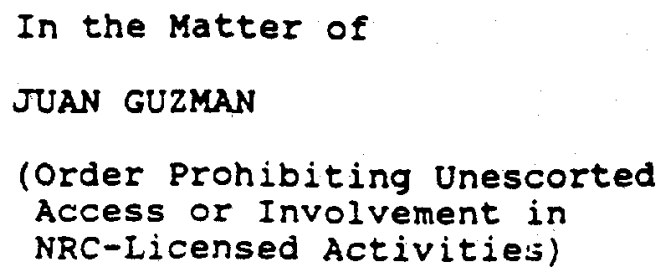

In the Matter of

JUAN GUZMAN

(Order Prohibiting Unescorted Access or Involvement in NRC-Iicensed ACtivitie's)

Docket No. IA 96-020

ASLBP No. 96-715-03-EA

October 16,1996

\section{MEMORANDUM AND ORDER \\ (Approving Settlement Agreement and Dismissing Proceeding)}

In a joint motion filed october 4,1996 , petitioners Juan and Laurene Guzman and the NRC staff ask the Licensing Board to approve an attached settlement agleement and dismiss this proceeding. Finding their settlement accord is consistent with the public interest, we approve the agreement and terminate this case.

At issue in this proceeding is an April 19, 1996 staff enforcement order issued in connection with Mr. Guzman's activities while employed as a contractor employee performing piping insulation work at Baltimore Gas and Electric Company's (BG\&E) Calvert Cliffs Nuclear Power Plant, Units 1 and 2 . The immediately effective order precludes $M r$. Guzman for a period of five years from (1) any involvement in NRC-licensed activities; and (2) obtaining 
unescorted access to an NRC-licensed facility. The order further provides this five-year period began on october 18, 1994, the date on which BG\&E revoked Mr. Guzman's unescorted access authorization and removed him from the protected area at the Calvert cliffs facility for purported misrepresentations regarding his immigration status at that time. As the basis for its order, the staff relies on Mr. Guzman's alleged attempts to falsify background information regarding himself, including providing a fraudulent "green card ${ }^{n}$ and social security card and denying that an arrest record obtained by submitting his fingerprints to the Federal Bureau of Investigation belonged to him. See 61 Fed. Reg. 18,630, 18,630-31 (1996). In a one-paragraph letter dated April 29, 1996, Mr. Guzman and his spouse, Laurene, requested a hearing in accordance with 10 C.F.R. $\$ 2.202$ to contest the staff's April 1996 order. In its May 31, 1996 initial prehearing order the Board sought to convene an eariy July 1996 prehearing conference, but subsequently granted a se:-ies of postponements to provide the Guzmans with additional time to find an attorney. ${ }^{1}$ Their efforts to obtain counsel,

1 Because the Guzmans appeared to be in some financiai distress, see, e.g., Reply to NRC staff Response Dated July 10, 1996 (Aug. 2, 1996) at 1, and based on our belief that in this enforcement proceeding the overall efficiency of the adjudicatory process would be materially aided if the Guzmans had counsel, the Board provided the Guzmans with information on organizations that could assist them in (continued...) 
however, ultimately were unsuccessful. Accordingly, on August 28, 1996, the Board conducted a prehearing conference during which Mr. Guzman (aided by a United States Department of State-certified Spanish interpreter ${ }^{2}$ ) and Mrs. Guzman appeared pro se.

At the prehearing conference, the Board heard presentations on the pending issues of the staff's challenge to Mrs. Guzman's standing and the efficacy of the staff's immediate effectiveness determination. ${ }^{3}$ See $\mathrm{Tr}$. at 9-64. The Board also considered the admissibility of certain "central Iitigation issues" proposed by the partjes. We concluded, among other things, that we would permit the enforcement order to be challenged on the ground the five-year prohibition term is excessive when compared to other, similar cases. See $\mathrm{Tr}$. at $58-70$; see also Radiation oncology Center at Marlton (Marlton, New Jersey), LBP-95-25, 42 NRC $237,238-39$ (1995). We also decided we wished to

1 (...continued)

obtaining free or reduced cost legal services. See Board Memorandum and order (Scheduling Prehearing Conference) (Aug. 12, 1996) at $3 \mathrm{n.2}$ (unpublished); Board Memorandum and order (Second Prehearing Order) (June 21, 1996) at 4 n.1 (unpublished).

2 The terms and conditions governing the use of that interpreter were specified in an attachment to an August 26 , 1996 Board issuance. See Board Memorandum (Use of Spanish Interpreter) (Aug. 26, 1996) attach. 1 (unpublished); see also Tr. at $3-6$.

3 Because we approve the settlement reached by the participants, we need not resolve these issues. 
receive additional submissions addressing the question of permitting litigation on the Guzman-proposed issue whether Mr. Guzman's status as a Mexican immigrant was a factor affecting the severity of the imposed prohibition. See Tr. at 70-73. Finally, the Board and the participants discussed future scheduling for the proceeding, which resulted in a directive that a sixty-day discovery period would begin immediately. See $T r$. at 74-83. See also Board order (Memorializing Filing Dates and Initiation of Discovery and Requesting settlement Status Report) (Aug. 30, 1996) at 1-2 (unpublished).

Following the August 28 prehearing conference, the Guzmans and the staff initiated settlement discussions. To permit negotiations to continue, on september 9,1996 , the Guzmans and the staff isked that we hold the proceeding, including the discovery and issue briefing schedules, in abeyance through the end of september. We granted this request, as well as a september 25, 1996 motion to continue the schedule suspension through mid-october. Thereafter, the participants filed the joint settlement motion now before us.

Under the terms of the October 4, 1996 settlement agreement, the staff agrees to modify the April 1996 enforcement order to reduce from five to three years the term of the prohibition on Mr. Guzman having any involvement in NRC-licensed activities or seeking/obtaining unescorted 
access to any NRC-licensed facility. Therefore, as revised, this prohibition would be in place until october 17, 1997. In addition, the settlement agreement provides that for a subsequent two-year period (i.e., October 17, 1997, through October 16, 1999), if Mr. Guzman seeks employment with any person whose operations he knows, or reasonably should know, involve NRC-licensed or regulated activity, prior to being hired he must provide that person with a copy of the April 1996 order and the settlement agreement. In turn, the Guzmans agree to withdraw their hearing request. Pursuart to slibsections (b) and (o) of section 161 of the Atomic Er.ergy Act of 1954, 42 U.S.C. $\$ 2201(\mathrm{~b}),(0)$, and 10 C.F.R. $\$ 2.203$, we have reviewed the participants' joint settlement agreement to determine whether approval of the agreement and termination of this proceeding is in the public interest. Based on that review, and according due weight to the position of the staff, we have concluded both actions are consonant with the public interest. We thus grant the participants' joint motion to approve the settlement agreement and dismiss this proceeding

For the foregoing reasons, it is this sixteenth day of October 1996, ORDERED that:

1. The October 4, 1996 joint motion of Juan and Laurene Guzman and the staff is granted and we approve their 
October 4, 1996 "Joint Settlement Agreement," which is attached to and incorporated by reference in this memorandum and order.

2. This proceeding is dismissed.

THE ATOMIC SAFETY

AND LICENSING BOARD
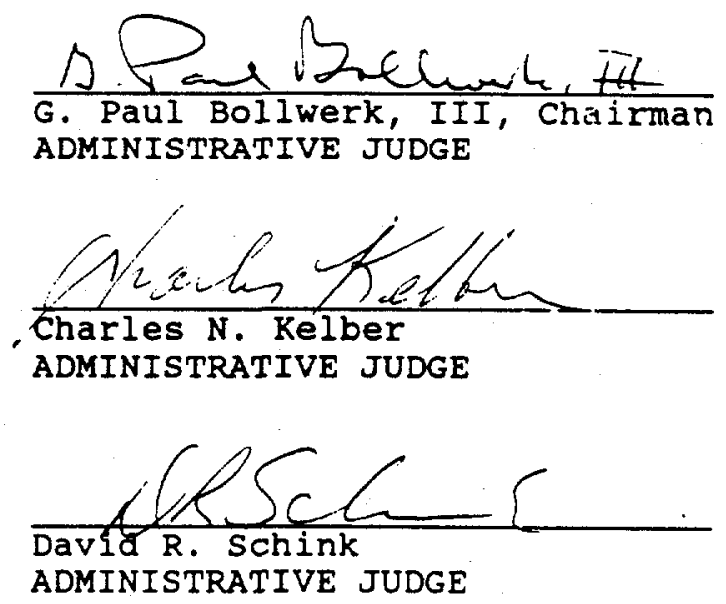

Rockville, Maryland

October 16,1996 


\section{UNITED STATES OF AMERICA \\ NUCLEAR REGULATORY COMMISSION}

\section{BEFORE THE ATOMIC SAFETY AND LICENSING BOARD}

In the Matter of

תUAN GUZMAN

(Order Prohibiting Unescorted Access or Involvement in NRC-Licensed Activities)
)

)

Docket No. LA 96-020

) ASLBP No. 96-715-03-EA

\section{JOINT SETTLEMENT AGREEMENT}

On April 19, 1996, the staff of the Nuclear Regulatory Commission (Staff) issued an Order Prohibiting Unescorted Access or Involvement in NRC-licensed Activities (Effective Imnediately) to Juar, Guzman. 61 Fxd. Reg. 18,630. On April 29, 1996, Juan Guzman along with his spouse, Laurene Guzman, requested a hearing on the April 19, 1996 order.' In response to Mr. and Mrs. Guzman's hearing request, an Atomic Safety and Licensing Board was estatlished on May 20, 1996. 61 Fed. Reg. 26,549.

After discussions between the Siaff and the Gurmans, both the Staff and the Guzmans agree that it is in their respective interests and in the public interest to settle this proceeding without further litigation, and agree to the following terms and conditions:

\footnotetext{
'Mrs Guzman's right to participate in the proceeding was challenged by the Staff, and
} the issue of her status is pending before the Atomic Safety and Licensing Board 
1. Juan and Laurene Guzman agree to withdraw their request for a hearing, dated April 29, 1996

2. The NRC Staff agrees to the modification of the Order Prohibiting Unescorted Access or Involvement in NRC-licensed Activities (Effective Immediately), dated April 19, 1996, as set forth in Paragraphs 3 and 4, below.

3. Juan Guzman agrees that from October 18, 1994, the date of his termination of unescorted access, until October 17, 1997, he is prohibited from seeking or obtaining unescorted access at any NRC-licensed facility and may not be involved in any NRC-licensed activities. For the purposes of this agseement, he term, "licensed activities" includes any and all activities which a licensee must or is permitted to perform in order to conduct activities authorized by its NRC-issued license, including those necessary to achieve compliance with all regulatory requirements imposed by the Commission.

4 Juan Guzman agrees that for two years following the three year prohibition, (that is, from October 17, 1997 to October 16, 1999), should he seek employment with any person (meaning an individual, a business, or other entity) whose operations he knows or reasonably should know involve any NRC-licensed or regulated activity, Mr. Guzman will provide a copy of the Aprii 19, i996 order and this agreement to that person prior to being hired, so that the person is aware of the Order in deciding whether to hire him. 


\section{$-3-$}

5. By signing this agreement, Mr. Guzman acknowledges his obligation, under federal statute and the Commission's regulations, to provide information to the NRC, an NRC licensee, or a contractor of an NRC licensee that is complete and accurate in all material respects. Mr. Guzman agrees that he will comply with all applicable NRC requirements.

6. Mr. Guzman acknowledges that he has read and fully understands the terms of this settlement agreement.

7. The Staff and Juan Guzman shall jointly move the Atomic Safety and Licensing Board designated in the above-captioned proceeding for an order approving this agreement and terminating this proceeding. Laurene Guzman shall file a notice of withdrawal of her hearing request at the same time the motion of the Staff and Mr. Guzman is filed. The terms of this agreement shall become effective upon approval of the Atomic Safety and Licensing Board.
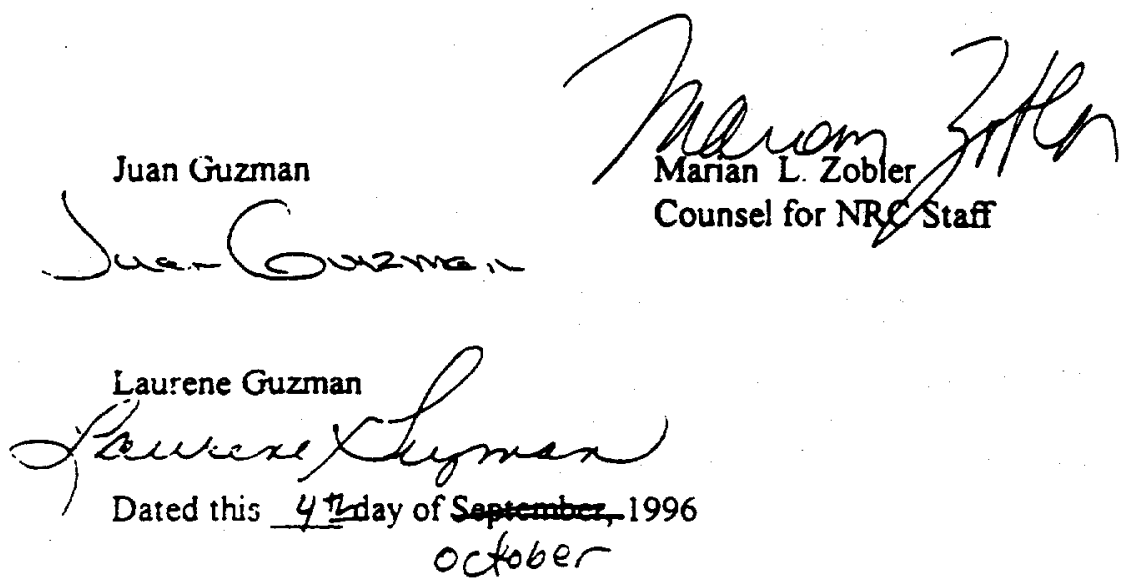


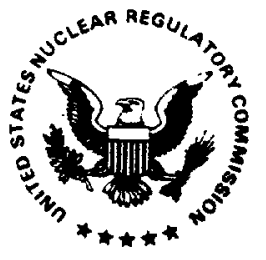

\author{
UNITED STATES \\ NUCLEAR REGULATORY COMMISSION \\ WASHINGTON, D.C. 20565-0001
}

July 16,1996

IA $90-042$

Mr. Mark Jenson

[HOME ADDRESS DELETED

UNDER 2.790]

\title{
SUBJECT: ORDER PROHIBITING INVOLVEMENT IN NRC-LICENSED ACTIVITIES
}

Dear Mr. Jenson:

The enclosed Order Prohibiting Involvement in NRC-Licensed Activities is being issued because of your deliberate misconduct, in violation of 10 CFR 30.10 of the Commission's regulations, as described in the order. The order becomes effective in 20 days unless a hearing is requested within this time.

Pursuant to Section 223 of the Atomic Energy Act of 1954, as amended, any person who willfully violates, attempts to violate, or conspires to violate, any provision of this Order, once it becomes effective, shall be subject to criminal prosecution as set forth in that section. Failure to comply with the provisions of this Order may also result in civil sanctions.

Questions concerning this Order should be addressed to Mr. James Lieberman, Director, Office of Enforcement, who may be reached at (301) 415-2741.

In accordance with 10 CFR 2.790 of the NRC's "Rules of Practice," a copy of this letter and the enclosure will be place in the NRC's Public Document Room.

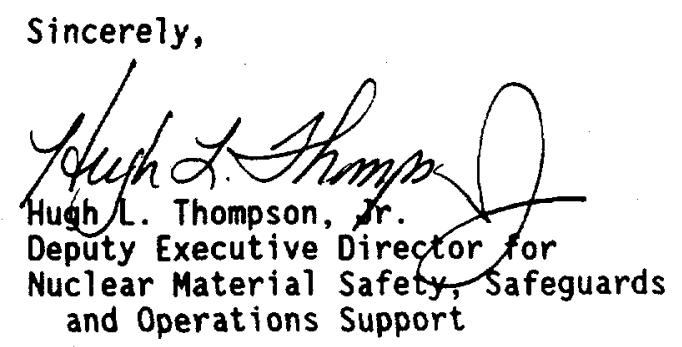

Enclosure: Order Prohibiting Involvement

in NRC-Licensed Activities

cc: Commonwealth of Puerto Rico 
In the Matter of

Mark A. Jenson

[HOME ADDRESS DELETED

UNDER 10 CFR 2.2790]
\{

IA $96-042$

\section{ORDER PROHIBITING INVOLVEMENT IN NRC-LICENSED ACTIVITIES}

1

Mark A. Jenson was employed as President of NDT Services, Inc. in Caguas, Puerto Rico, in 1993. NDT Services, Inc. (NDTS or Licensee) holds License No. 52-19438-01, issued to the Licensee in 1987 and last amended by the Nuclear Regulatory Commission (NRC or Commission) pursuant to 10 CFR Part 30 on March 9, 1995. The license authorizes industrial gamma ray radiography in accordance with the conditions specified therein. Mr. Jenson was identified in a letter from the Licensee to NRC, dated September 4,1993, and in other licensing and inspection correspondence, as the President, NDTS.

On December 16-17, 1993, a special inspection of NDTS' activities was conducted at the Licensee's facility in Caguas, Puerto Rico, in response to notifications received in the NRC Region II office that on September 4, 1993, two contract radiographers ${ }^{1}$ employed by NOTS had been unable to return a radiography source to its shielded position following radiographic operations, which resulted in the evacuation of the Sun 0 il Company refinery in Yabucoa,

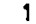

The radiographers involved in the event were contracted by Mots from Mational Inspection and Consultants (NIC), an Agreement state licensee in florida. While no written contract was established to outline the scope and conditions of work, based on the information available, the MRC concluded that the work performed on September 4, 1993, was performed under the provisions of the wDTS license. 
Puerto Rico, for several hours. Based on the results of the inspection, an investigation was initiated by the NRC Office of Investigations (OI) on December 30, 1993.

On December 21, 1995, OI completed its investigation and concluded, in part, that NDTS, with the knowledge and approval of the former Radiation Safety Officer (RSO) and former President, deliberately utilized radiographers untrained in NDTS operating and emergency procedures. During an August 31 , 1995 interview with $\mathrm{OI}, \mathrm{Mr}$. Jenson stated that he was aware that even a highly qualified radiographer from another company must receive additional training before operating under NDTS' program. Mr. Jenson further stated that, prior to the September 4, 1993 incident, NDTS' former RSO told Mr. Jenson that the radiographers needed additional training prior to performing radiography. Nonetheless, Mr. Jenson allowed the radiographers to conduct licensed activities without the required training. In addition, Mr. Jenson stated that, following the September 4, 1993 incident, he requested both radiographers to sign a document certifying that the radiographers had been trained by NDTS, when in fact, they had not been. The radiographers refused to sign the document. Furthermore, during a May 10, 1995 transcribed interview with OI, one of the radiographers corroborated Mr. Jenson's admission (i.e., that Mr. Jenson asked the radiographer to sign a document indicating that the radiographer had been trained).

By letter dated February 20,1996, Mr. Jenson was informed of the inspection and investigation results and was provided the opportunity to participate in a predecisional enforcement conference. Although the NRC has confirmation that 
Mr. Jenson received the letter (i.e., returned certified mail receipt as well as a telephone acknowledgement by his spouse to the NRC on February 29, 1996), Mr. Jenson never responded to the letter and, therefore, no conference has been conducted with him. However, on May 17, 1996, a teleconference was conducted with Mr. Jenson to further discuss this case. Additionally, on February 29 and March 4, 1996, predecisional enforcement conferences were conducted with one of the contract radiographers, and NDTS, respectively.

Based on the information gathered during the inspection, investigation, predecisional enforcement conferences, and subsequent interviews in this case, the NRC has determined that: (1) Mr. Jenson deliberately permitted unqual ified radiographers to perform radiography for NDTS on September 4 , 1993 , in that he knew the radiographers had not been trained in NDTS procedures or equipment; and (2) Mr. Jenson attempted to generate a false, NRC-required training record for the contract radiographers involved in the source disconnect event when, subsequent to September 4, 1993, he requested both individuals to sign a document indicating that the individual had been trained in the NDTS radiation safety manual and procedure, when in fact, the contract radiographer had not been trained.

\section{III}

Based on the above, the staff concludes that Mr. Jenson engaged in deliberate misconduct, a violation of 10 CFR 30.10, which caused the Licensee to be in violation of 10 CFR 34.31 (a) by failing to utilize trained and qualified individuals for the conduct of radiographic operations at the Sun 0il Company 
refinery on September 4, 1993. Mr. Jenson's attempt to generate a falsified training record for the radiographer also demonstrates a lack of integrity which cannot be tolerated. As the former President of NOTS, Mr. Jenson was responsible for ensuring that NDTS conducted activities in accordance with NRC requirements. The NRC must be able to rely on the Licensee, its officials and employees to comply with NRC requirements, including the requirements to train radiographers in accordance with NRC regulations and to maintain complete and accurate information required by the NRC. Mr. Jenson's deliberate misconduct in causing the Licensee to violate 10 CFR 34.31 (a) is a violation of 10 CFR 30.10 and has raised serious doubt as to whether he can be relied upon to comply with NRC requirements.

Consequently, I lack the requisite reasonable assurance that licensed activities can be conducted in compliance with the Commission's requirements and that the health and safety of the public will be protected if Mr. Jenson were permitted at this time to be involved in NRC-licensed activities. Therefore, the public health, safety and interest require that Mr. Jenson be prohibited from any involvement in NRC-licensed activities for a period of five years, and, if he is currently involved with another licensee in NRC-licensed activities, he must, following the effective date of this order, cease such activities, and inform the NRC of the name, address and telephone number of the employer, and provide a copy of this Order to the employer. Additionally, Mr. Jenson is required to notify the NRC of his first employment involving NRC-licensed activities within a period of five years following the five-year prohibition period. 
Accordingly, pursuant to sections $81,161 \mathrm{~b}, 161 \mathrm{i}, 182$ and 186 of the Atomic Energy Act of 1954, as amended, and the Commission's regulations in

10 CFR 2.202, and 10 CFR 30.10, IT IS HEREBY ORDERED THAT:

A. For a period of five years from the effective date of this Order, Mark A. Jenson is prohibited from engaging in, or exercising control over individuals engaged in, NRC-licensed activities. NRC-licensed activities are those activities which are conducted pursuant to a specific or general license issued by the NRC, including, but not limited to, those activities of Agreement State licensees conducted pursuant to the authority granted by 10 CFR 150.20. This prohibition includes, but is not limited to: (1) using licensed materials or conducting licensed activities in any capacity within the jurisdiction of the NRC; and (2) supervising or directing any licensed activities conducted within the jurisdiction of the NRC.

B. At least five days prior to the first time that Mark $A$. Jenson engages in, or exercises control over, NRC-licensed activities within a period of five years following the five-year prohibition period outlined in Section IV.A above, he shall notify the Director, Office of Enforcement, U. S. Nuclear Regulatory Commission, Washington, D.C. 20555, of the name, address, and telephone number of the NRC or Agreement State licensee and the location where the licensed activities will be performed. The notice shall be accompanied by a statement, under oath 
or affirmation, that Mark $A$. Jenson understands NRC requirements, that he is committed to compliance with NRC requirements, and that provides a basis as to why the Commission should have confidence that he will now comply with applicable NRC requirements.

The Director, Office of Enforcement, may, in writing, relax or rescind any of the above conditions upon demonstration by Mr. Jenson of good cause.

\section{V}

In accordance with 10 CFR 2.202, Mark A. Jenson must, and any other person adversely affected by this Order may, submit an answer to this Order, and may request a hearing on this Order, within 20 days of the date of this Order. Where good cause is shown, consideration will be given to extending the time to request a hearing. A request for extension of time must be made in writing to the Director, Office of Enforcement, U.S. Nuclear Regulatory Commission Washington, D.C. 20555, and include a statement of good cause for the extension. The answer may consent to this Order. Unless the answer consents to this Order, the answer shall, in writing and under oath or affirmation, specifically admit or deny each allegation or charge made in this order and shall set forth the matters of fact and law on which Mr. Jenson or other person adversely affected relies and the reasons as to why the Order should not have been issued. Any answer or request for a hearing shall be submitted to the Secretary, U.S. Nuclear Regulatory Commission, Attn: Chief, Docketing and Service Section, Washington, DC 20555. Copies also shall be sent to the Director, Office of Enforcement, U.S. Nuclear Regulatory Commission, 
Washington, DC 20555, to the Assistant General Counsel for Hearings and Enforcement at the same address, to the Regional Administrator, NRC Region II, Suite 2900, 101 Marietta Street, Atlanta, GA 30323, and to Mark A. Jenson, if the answer or hearing request is by a person other than Mark $A$. Jenson. If a person other than Mark $A$. Jenson requests a hearing, that person shall set forth with particularity the manner in which his or her interest is adversely affected by this Order and shall address the criteria set forth in 10 CFR $2.714(d)$.

If a hearing is requested by Mark A. Jenson, or another person whose interest is adversely affected, the Commission will issue an Order designating the time and place of any hearing. If a hearing is held, the issue to be considered at such hearing shall be whether this order should be sustained.

In the absence of any request for hearing, or written approval of an extension of time in which to request a hearing, the provisions specified in Section IV above shall be final 20 days from the date of this order without further order or proceedings. If an extension of time for requesting a hearing has been approved, the provisions specified in Section IV shall be final when the extension expires if a hearing request has not been received.

FOR THE NUCLEAR REGULATORY COMMISSION

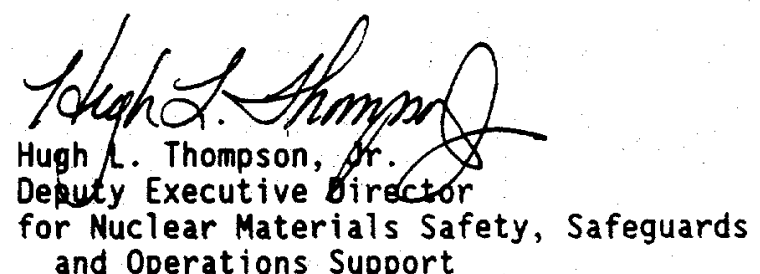

Dated at Rockville, Maryland this 16thay of July 1996 


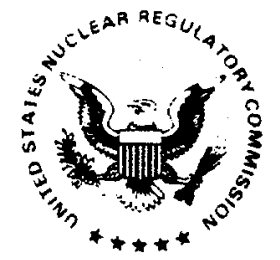

\section{UNITED STATES \\ NUCLEAR REGULATORY COMMISSION \\ WASHINGTON, D.C. 20555-0001}

June 12,1995

EA $94-240$

IA $95-015$

IA $95-016$

Midwest Testing, Inc.

ATTN: Mr. William Kimbley, President

Ms. Joan Kimbley, General Manager and

Treasurer

2421 Production Drive

Indianapolis, Indiana 46241

SUBJECT: CONFIRMATORY ORDER AND NOTICE OF TERMINATION OF LICENSE

(OI INVESTIGATION REPORT NO. 3-93-022R)

Dear Mr. and Ms. Kimbley:

The Confirmatory Order (Order) to which you agreed on June 2, 1995, has been executed. A signed copy of the order is enclosed. In addition, your license has been terminated as of the date of this letter in accordance with the Order Suspending License dated August 26, 1994. Enclosed is a copy of Amendment 1 terminating License No. 030-24866-02. We consider this matter settled.

Under the terms of this Order, for a period of five years beginning June 2, 1995, you, as well as Midwest Testing, Inc. and any successor entity, are prohibited from applying to the NRC for a license, and prohibited from engaging in, or controlling, any NRC-licensed activity. Should you violate the terms of the Order, you may be subject to civil and criminal sanctions under Sections 233 and 234 of the Atomic Energy Act of 1954, as amended.

Questions concerning this Order should be addressed to me at (301) 415-2741.

In accordance with 10 CFR 2.790 of the NRC's "Rules of Practice", a copy of this letter and its enclosure will be placed in the NRC Public Document Room.

Enclosures: As Stated

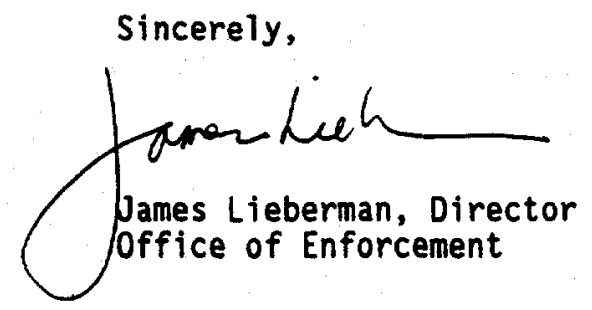

Docket No. 030-32827

License No. 13-24866-02 
UNITED STATES

NUCLEAR REGULATORY COMMISSION

In the Matter of

MIDWEST TESTING, INC.

Indianapolis, Indiana

MR. WILLIAM G. KIMBLEY

MS. JOAN KIMBLEY

\{

Docket No. 030-32827

License No. 13-24866-02

EA 94-240

IA 95-015

IA $95-016$

CONF IRMATORY ORDER

I

Midwest Testing, Inc. (Licensee) is holder of NRC License No. 13-24866-02

(License) issued by the Nuclear Regulatory Commission (NRC or Commission) pursuant to 10 CFR Part 30. The License authorized the Licensee to possess and use cesium-137 and americium-241 as sealed sources in moisture/density gauges. The License was issued on August 19, 1992; and is being terminated by Amendment No. 1, which is being issued on the date of this Order.

On July 27,1993 , a routine inspection of licensed activities was conducted at Midwest Testing, Inc. (Licensee) by NRC Region III. During the inspection the inspector identified that licensee management had allowed workers to operate moisture density gauges without personnel monitoring devices (film badges) and that required leak tests of the gauges had not been performed.

The NRC Office of Investigations (OI) conducted an investigation to determine whether willful violations of NRC requirements had occurred. Based on the NRC inspection and $O I$ investigation, it appears that Mr. William G. Kimbley, owner 
of Midwest Testing, deliberately violated NRC requirements by:

(1) allowing operators to use moisture density gauges without personnel monitoring devices between December 24, 1991, and August 25, 1993, in violation of Condition 18. A of License No. 13-24866-01 (expired on March 31, 1992) and Condition 20.A of License No. 13-24866-02 (issued on August 19, 1992);

(2) not performing leak tests of two moisture density gauges between August 19, 1992, and July 31, 1993, in violation of Condition.13.A of License No. 13-24866-02;

(3) not requesting a license amendment to name a new Radiation Protection Officer, in violation of Condition 11 of License No. 13-24866-02, when the individual named on the License left Midwest Testing in October 1993;

(4) storing licensed material at an unauthorized location since March 1994 in violation of Condition 10 of License No. 13-24866-02 and 10 CFR $30.34(c)$; and

(5) allowing moisture density gauges to be used between April 1, 1992, and August 19, 1992, with an expired license in violation of 10 CFR 30.3 and 10 CFR $30.36(c)(1)(i)$ and (iii). 
In addition, it appears that Ms. Joan Kimbley, General Manager and Treasurer of Midwest Testing, Inc., deliberately violated Items (1), (2), and (5) above. These actions appear to have been a result of Midwest Testing, Inc. financial constraints, inexperience of the General Manager and, in general, a lack of appreciation on the part of the Owner and the General Manager of the regulatory significance and consequences of the violations.

A Confirmatory Action Letter was issued to the Licensee on March 21, 1994, confirming that the Licensee would secure its moisture density gauges in locked storage until the Licensee: (1) designated a Radiation Protection Officer, (2) obtained NRC approval via a license amendment for its designated Radiation Protection officer and its current moisture density gauge storage location, (3) demonstrated that all its moisture density gauges were appropriately tested for leakage, and (4) demonstrated that personnel radiation monitoring devices were provided for those persons designated to use moisture density gauges. The Licensee did not use its moisture density gauges after issuance of the Confirmatory Action Letter.

Subsequentiy, an Order Suspending License (Effective Immediately) was issued to the Licensee on August 26, 1994, for nonpayment of fees, which required: (1) the Licensee to suspend MRC licensed activities and dispose of its licensed material; and (2) NRC termination of License No. 13-24866-02 following disposal of the licensed material. The Licensee disposed of its licensed material in December 1994. NRC Region III verified that the licensed material was properly transferred to authorized recipients. 
A transcribed enforcement conference was conducted between the NRC and the Licensee on March 15, 1995, to discuss the apparent violations, their causes and safety significance. Mr. Kimbley stated during the enforcement conference, "And the question about would we ever pursue an NRC license again, the answer to that is no. If there is any way I can give you assurance of that, I'll be glad to do that." Ms. Kimbley stated during the Enforcenent Conference, "Like we stated earlier, we don't intend to continue with any licensed material in the future."

Further, in a telephone conversation on May 2, 1995, with Mr. Paul Pelke, NRC Region III, Mr. and Ms. Kimbley agreed to the provisions and to the issuance of this Order to resolve all matters pending between them. Specifically, Mr. Kimbley agreed, for a period of five years from the date he signs this Confirmatory Order, that Mr. Kimbley, Midwest Testing, Inc., or any successor entity wherein Mr. Kimbley is an authorized user, radiation safety officer, owner, an officer, or a controlling stockholder, will not apply to the NRC for a new license, nor shall Mr. Kimbley, Midwest Testing, Inc., or a successor entity, as described above, engage in licensed activities within the jurisdiction of the NRC for that same period of time. Ms. Kimbley agreed, for a period of five years frow the date she signs this Confirmatory Order, that Ms. Kimbley, Midwest Testing, Inc., or any successor entity wherein Ms. Kimbley is an authorized user, radiation safety officer, owner, an officer, or a controlling stockholder, will not apply to the NRC for a new license, nor shall Ms. Kimbley, Midwest Testing, Inc., or a successor entity, 
as described above, engage in licensed activities within the jurisdiction of the NRC for that same period of time.

I find that the Licensee's commitments as stated in the May 2, 1995 conversation with Paul Pelke, NRC Region III, are acceptable and necessary and conclude that with these commitments the public health and safety are reasonably assured. In view of the foregoing, I have determined that the public health and safety require that the Licensee's commitments be confirmed by this Order.

Accordingly, pursuant to sections $81,161 \mathrm{~b}, 161 \mathrm{i}$, and 186 of the Atomic Energy Act of 1954, as amended, and the Commission's regulations in 10 CFR 2.202, and 10 CFR Part 30 , IT IS HEREBY ORDERED that:

1. For a period of five years from the date Mr. William G. Kimbley signs this Confirmatory Order, Mr. Kimbley, Midwest Testing, Inc., or any successor entity wherein Mr. Kimbley is an authorized user, radiation safety officer, owner, an officer, or a controlling stockholder, will not apply to the NRC for a new license, nor shall Mr. Kimbley, Midwest Testing, Inc., or a successor entity, as described above, engage in licensed activities within the jurisdiction of the NRC for that same period of time. 
2. For a period of five years from the date Ms. Joan Kimbley signs this Confirmatory Order, Ms. Kimbley, Midwest Testing, Inc., or any successor entity wherein Ms. Kimbley is an authorized user, radiation safety officer, owner, an officer, or a controlling stockholder, will not apply to the NRC for a new license, nor shall Ms. Kimbley, Midwest Testing, Inc., or a successor entity, as described above, engage in licensed activities within the jurisdiction of the NRC for that same period of time.

3. Mr. Kimbley, Ms. Kimbley, Midwest Testing, Inc., or any successor entity, as described above, waive the right to contest this order in any manner, including requesting a hearing on this Order.

The Regional Administrator, NRC Region III, may relax or rescind, in writing, any of the above conditions upon a showing by the Licensee, Mr. William G. Kimbley, or Ms. Joan Kimbley of good cause.

\section{V}

Any person adversely affected by this Confirmatory Order, other than the Licensee, Mr. Millian G. Kimbley, and Ms. Joan Kimbley may request a hearing within 20 days of its issuance. Any request for a hearing shall be submitted to the Secretary, U.S. Nuclear Regulatory Commission, ATTN: Chief, Docketing and Service Section, Washington, D.C. 20555. Copies also shall be sent to the Director, Office of Enforcement, U.S. Nuclear Regulatory Comnission, Washington, D.C. 20555, to the Assistant General Counsel for Hearings and 
Enforcement at the same address, to the Regional Administrator, NRC Region III, 801 Warrenville Road, Lisle, Illinois 60532, and to the Licensee. If such a person requests a hearing, that person shall set forth with particularity the manner in which his interest is adversely affected by this Order and shall address the criteria set forth in 10 CFR 2.714(d).

If a hearing is requested by a person whose interest is adversely affected, the Commission will issue an Order designating the time and place of any hearing. If a hearing is held, the issue to be considered at such hearing shall be whether this Confirmatory Order should be sustained.

In the absence of any request for hearing, the provisions specified in Section IV above shall be final 20 days from the date of this Order without further order or proceedings.

This Order was consented to:

FOR THE LICENSEE, WILLIAM G. KIMBLY, AND JOAN KIMBLY

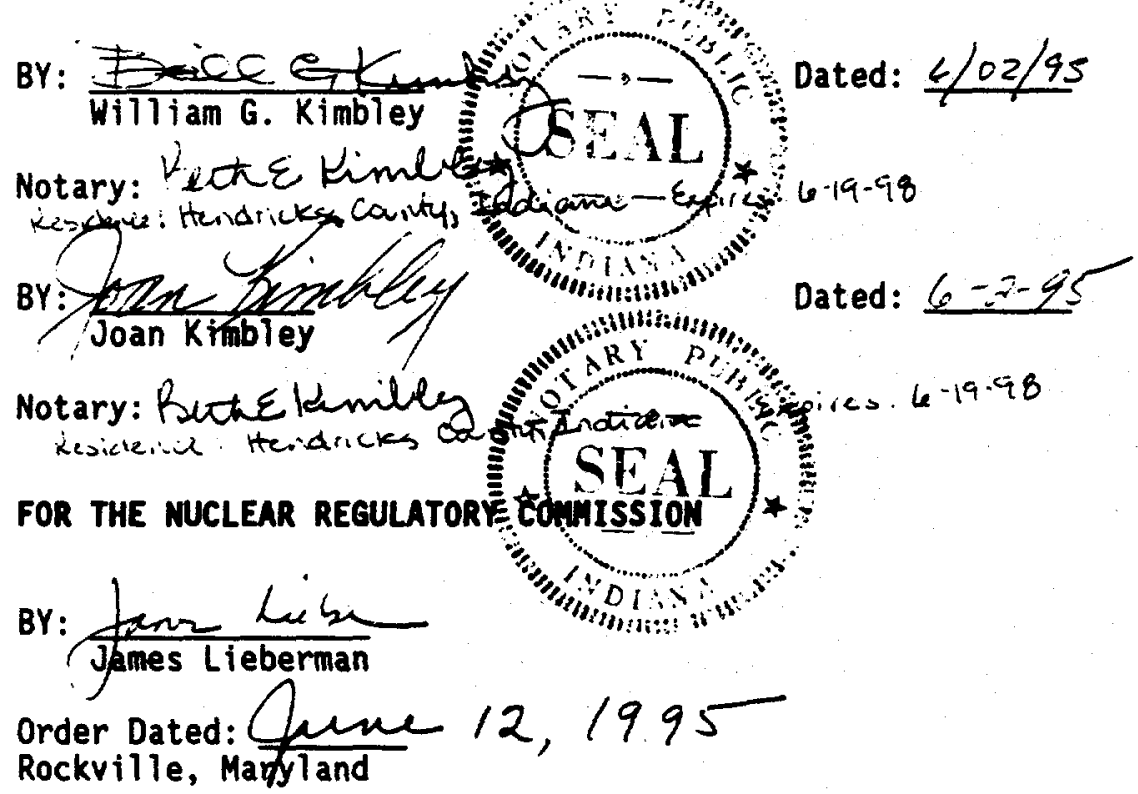




\section{UNTED STATES \\ NUCLEAR REQULATORY COMMISSION \\ washinaton, o.c. sexpan}

\section{AUG $2: 6 \quad$ i994}

IA $94-019$

Mr. Larry S. Ladner

(HOME ADORESS DELETEO

UNDER 10 (FR 2.790)

\section{SUBJECT: ORDER PROHIBITING INVOLVEMENT IN NRC-LICENSED ACTIVITIES (EFFECTIVE IMMEDIATELY)}

The enclosed Order is being issued because of-your violations of 10 CFR 30.10 of the Commission's regulations as described in the Order.

Based on an investigation conducted by the NRC's Office of Investigation, the NRC Staff has determined that you deliberately failed to supervise

radiographers' assistants performing licensed activities, falsified a large number of quarterly personnel audits and provided false information to NRC officials. A copy of the synopsis of the investigation is enclosed.

Failure to comply with the provisions of this order may result in further civil or criminal sanctions.

Questions concerning this Order should be addressed to Mr. James Lieberman, Director, Office of Enforcement, who can be reached at (301) 504-2741.

In accordance with 10 CFR 2.790 of the NRC's "Rules of Practice," a copy of this letter and the enclosures will be placed in the NRC's Public Document Room.

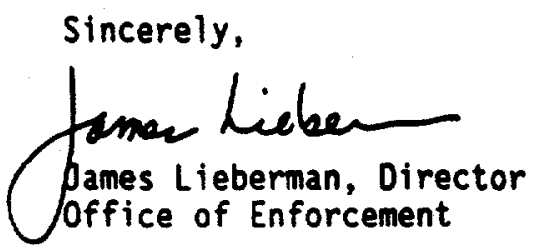

Enclosures:

1. Order

2. Synopsis 
UNITED STATES

NUCLEAR REGULATORY COMMISSION

In the Matter of

Larry S. Ladner

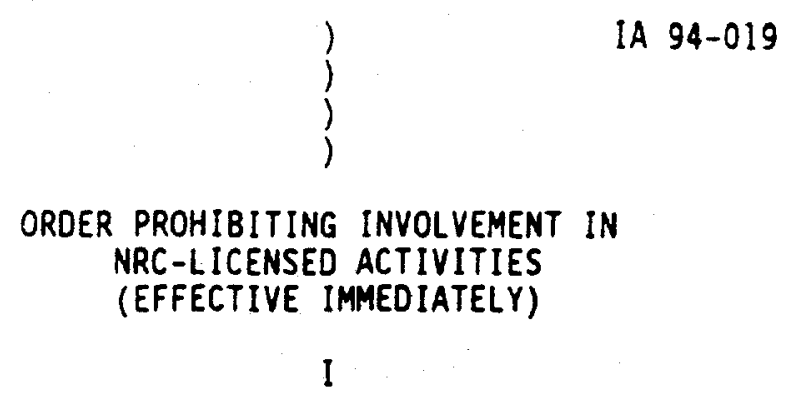

Larry S. Ladner has been employed as a radiographer in the field of industrial radiography since approximately 1964. In October, 1989, Mr. Ladner was hired by the American Inspection Company, Inc. (AMSPEC). AMSPEC held Materials License No. 12-24801-01 issued by the Nuclear Regulatory Commission (NRC or Commission) pursuant to 10 CFR Parts 30 and 34 . This license authorized the conduct of industrial radiography activities in accordance with certain specified conditions. On April 30, 1992, the license was suspended as a result of significant safety violations and related safety concerns. Mr. Ladner worked as both a radiographer and a supervisor until his dismissal by AMSPEC in the latter part of 1991 .

Between August 22, 1991 and November 12, 1992, the NRC Office of Investigations (OI) conducted an investigation of licensed activities of AMSPEC. During the course of this investigation, the AMSPEC license was suspended when a significant number of safety violations were identified. In addition, the investigation revealed that Mr. Ladner, in his position as a supervisor (1) deliberately allowed radiographers' assistants to work 
unsupervised on numerous occasions, (2) deliberately falsified in excess of 100 quarterly personnel audits, and (3) deliberately gave false information to NRC officials regarding the unauthorized use of licensed material.

10 CFR 34.44 requires that a radiographer's assistant shall be under the personal supervision of a radiographer whenever he uses radiographic exposure devices, sealed sources or related source handling tools, or conducts radiation surveys required by 10 CFR 34.43 (b) to determine that the sealed source has returned to the shielded position after an exposure. The personal supervision shall include: (a) the radiographer's personal presence at the site where the sealed sources are being used; (b) the ability of the radiographer to give immediate assistance if required; and (c) the radiographer watching the assistant's performance, of the operations referred to in this section. In addition, 10 CFR $34.11(d)(1)$ requires, in part, that an applicant have an inspection program that requires the observation of the performance of each radiographer and radiographer's assistant during an actual radiographic operation at intervals not to exceed three months.

10 CFR 30.9 (a) requires, in part, that information provided to the Commission by a licensee, and information required by the Comaission's regulations to be maintained by the licensee, shall be complete and accurate in all material respects.

While functioning as a radiation protection officer, Mr. Ladner deliberately caused a violation of 10 CFR 34.44 in December 1990 and February through May 1991 by allowing three radiographers' assistants to work independently and without personal supervision. Ouring this same period, Mr. Ladner also 
authorized others to use his name on check-out logs, in violation of 10 CFR 30.10. Moreover, Mr. Ladner's employer (AMSPEC) had an approved program that required the observation of radiographers and radiographers' assistants at the required interval as prescribed by 10 CFR 34.11(d); however, between September 1990 and November 1991, he deliberately disregarded the licensee's program in excess of 100 times by falsifying records of audits that were never performed, causing a violation of 10 CFR 30.9. During an NRC inspection conducted on July 22-23, 1991, Mr. Ladner deliberately provided inaccurate information to NRC inspectors when he claimed no knowledge of a reported unauthorized use of licensed material, when. in fact he was aware of such use.

On January 15, 1993, Mr. Ladner pled guilty to one felony count involving deliberate violations of the Atomic Energy Act based on his violations of these requirements.

\section{III}

Based on the above, Mr. Ladner engaged in del iberate misconduct which caused AMSPEC to be in violation of 10 CFR 30.9 and $34.11(d)$. The NRC must be able to rely on licensees and their employees to comply with NRC requirements, including the requirements to supervise radiographer's assistants performing licensed activities and to maintain and compile records that are complete and accurate in all material respects. Mr. Ladner's deliberate actions in causing AMSPEC to be in violation of MRC requirements (e.g. 30.9 and $34.11(d)$ ), and his deliberate submittal to AMSPEC of false audit records, which are violations of 10 CFR 30.10 , have raised serious doubt as to whether he can be relied on to comply with NRC requirements and to provide complete and accurate 
information to the NRC. Mr. Ladner's deliberate misconduct, including his deliberate false statements to Commission officials, cannot and will not be tolerated.

Consequently, I lack the requisite reasonable assurance that licensed activities can be conducted in compliance with the Comission's requirements and that the health and safety of the public will be protected, if Mr. Ladner were permitted at this time to supervise or perform licensed activities in any area where the NRC maintains jurisdiction. Therefore, the public health, safety and interest require that Mr. Ladner be prohibited from engaging in NRC licensed activities (including supervising, training and auditing) for either an NRC licensee or an Agreement State licensee in areas of NRC jurisdiction in accordance with 10 CFR 150.20 for a period of three years from the date of this Order. In addition, for a period of two years commencing after completion of the three year period of prohibition, Mr. Ladner is required to notify the NRC of his employment by any person or entity engaged in NRClicensed activities to ensure that the NRC can monitor the status of Mr. Ladner's compliance with the Commission's requirements and his understanding of his commitment to compliance. Furthermore, pursuant to 10 CFR 2.202, I find that the significance of the conduct described above is such that the public health, safety and interest require that this order be effective immediately.

Accordingly, pursuant to sections $81,161 \mathrm{~b}, 161 \mathrm{i}, 182$ and 186 of the Atomic Energy Act of 1954, as amended, and the Commission's regulations in 
10 CFR 2.202, 10 CFR 30.10, and 10 CFR 150.20, IT. IS HEREBY ORDERED, EFFECTIVE IMMEDIATELY, THAT:

1. Larry S. Ladner is prohibited for three years from the date of this Order from engaging in NRC-licensed activities. NRC-licensed activities are those activities which are conducted pursuant to a specific or general license issued by the NRC, including, but not limited to, those activities of Agreement State licensees conducted pursuant to the authority granted by 10 CFR 150.20. During this time period, Mr. Ladner must also provide a copy of this Order to prospective employers who engage in NRC-1icensed activities, at the time he accepts employment.

2. For a period of two years after the three-year period of prohibition has expired, Larry S. Ladner shall within 20 days of his acceptance of an employment offer involving NRC-licensed activities or his becoming involved in NRC-licensed activities, as defined in Paragraph IV.l above, provide notice to the Director, Office of Enforcement, U. S. Nuclear Regulatory Commission, Washington, D.C. 20555, of the name, address, and telephone number of the employer or the entity where he is, or will be, involved in the MRC-licensed activities. In the first notification Mr. Ladner shall include a statement of his commitment to compliance with regulatory requirements and the basis why the Commission should have confidence that he will now comply with applicable NRC requirements.

The Director, Office of Enforcement, may in writing, relax or rescind any of the above conditions upon demonstration by Mr. Ladner of good cause. 
In accordance with 10 CFR 2.202, Larry S. Ladner must, and any other person adversely affected by this Order may, submit an answer to this Order, and may request a hearing on this Order, within 20 days of the date of this Order. The answer may consent to this Order. Unless the answer consents to this Order, the answer shall,. in writing and under oath or affirmation, specifically admit or deny each allegation or charge made in this Order and shall set forth the matters of fact and law on which Larry S. Ladner or any other person adversely affected relies and the reasons as to why the Order should not have been issued. Any answer or request for a hearing shall be submitted to the Secretary, U.S. Nuclear Regulatory Commission, Attn: Chief, Docketing and Service Section, Washington, DC 20555. Copies also shall be sent to the Director, Office of Enforcement, U. S. Nuclear Regulatory Commission, Washington, DC 20555, to the Assistant General Counsel for Hearings and Enforcement at the same address, to the Regional Administrator, NRC Region II, 101 Marietta Street, M. H., Suite 2900, Atlanta, Georgia 30323, and to Larry S. Ladner if the answer or hearing request is by a person other than Larry S. Ladner. If a person other than Larry $\mathbf{S}$. Ladner requests a hearing, that person shall set forth with particularity the manner in which his or her interest is adversely affected by this Order and shall address the criteria set forth in 10 CFR $2.714(d)$.

If a hearing is requested by Larry $S$. Ladner or another person whose interest is adversely affected, the Comission will issue an Order designating the time and place of any hearing. If a hearing is held, the issue to be considered at such hearing shall be whether this Order should be sustained. 
Pursuant to 10 CFR 2.202(c)(2)(i), Larry S. Ladner, or any other person adversely affected by this Order, may, in addition to demanding a hearing, at the time the answer is filed or sooner, move the presiding officer to set aside the immediate effectiveness of the Order on the ground that the Order, including the need for immediate effectiveness, is not based on adequate evidence but on mere suspicion, unfounded allegations, or error.

In the absence of any request for hearing; the provistons specified in Section IV above shall be final 20 days from the date of this Order without further order or processing. AN ANSWER OR A REQUEST FOR HEARING SHALL NOT STAY THE IMMEDIATE EFFECTIVENESS OF THIS ORDER.

FOR THE NUCLEAR REGULATORY COMNISSION

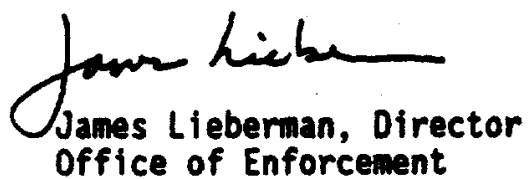

Dated at Rockville, Maryland this 26th day of August 1994 
on August 22, 1991, the Regional Administrator, U.S. Nuclear Regulatory Comission (NRC), Region II, requested an investigation to determine whether officials, managers, and/or employees of The American Inspection Company, Inc. (AMSPEC), the licensee, had intentionally violated regulatory and license condition requirements set forth in 10 CFR Parts 20,30 , and 34 and the NRC Iicense of January 15, 1987, respectively. According to reported allegations, licensee management officials had permitted unqualified technicians to perform radiography operations at the Hess Oil Virgin Islands Company (HOVIC) facility, St. Croix, U.S. Virgin Islands, which had contracted with AMSPEC for nondestructive examination services. Additionally, licensee offlcials allegedly: (1) discriminated (involuntary termination) against technicians for reporting radiation health and safety concerns, (2) falsified radiation safety training documents, (3) provided false and misleading information to the NRC, and (4) used source material in a manner not authorized by the license (irradiation of mice).

The office of Investigations (OI) reviewed the circumstances of the alleged regulatory and license condition violations during which other improprieties by the licensee were identified. The investigation by oI did not substantiate that licensee management officials had terminated radiography technlcians for reporting radiation health and safety concerns. It was concluded, however, that these licensee officials at the HovIC facility appeared insensitive to employee concerns of all topics, including radiation safety, and they were perceived by technicians as acting with apparent disregard concerning this issue. The investigation further determined that licensee officials deliberately provided false and misleading radiation safetyrelated information to NRC representatives which was pertinent to the regulatory process. The investigation substantiated that the licensee, through actions of some radiation protection officers (RPOS), deliberately falsified radiation safety training records, inserted false records in technician files to give the impression required training was accomplished, and they also conspired to conceal these training deficiencies and improprieties from the NRC. The investigation surfaced and substantiated the allegation that licensee offlcials and RPOs deliberately falsified required personnel radiation safety audits and accompanying reports and they also created audit reports to make complete the radiation safety tiles of some technicians.

The investigation also disclosed and confirmed numerous instances of radiographers' assistants performing radiography without supervision and the deliberate falsilication of source utilization loge to give the appearance that required supervision was present, all with the apparent knowledge and concurrence of licensee managenent officiais. It was also determined during the investigation that licensee training officlals (RPOs) frequenty 
failed to provide the Operation and Emergency Procedures (O\&EP) Manual to new employees prior to source utilization. The investigation also determined that some licensee RPOs were not trained, examined, and certified according to Radíation Safety Program requirements and AMSPEC officlals, including the radiation safety offlcer (RSO) and several RPOs, were aware of some of these violations and failed to correct them. Further, on at least one occasion, the RSO and an RPO conspired to concoct a plausible explanation for the NRC as to why RPO examination/certification requirements were violated.

The investigation substantiated the allegation that radioactive source material was utilized improperly when an AMSPEC night shift supervisor, in the presence of technicians, radiographed a mouse during two to three consecutive source exposures at the HOVIC facility. The OI Investigation, and a previous NRC inspection at the st. Crolx location, also revealed instances in which AMSPEC techniclans failed to observe required surveying and posting activities during radiography operations, actions which demonstrated either an apparent disregard for regulations and/or radiation safety training deficiencies. Finally, the investigation disclosed that the RSO and other Iicensee management officials deliberately failed to perform required radiation safety review, evaluation, and oversight functions and responsibilities during the past 3 years.

Case No. 2-91-010R 


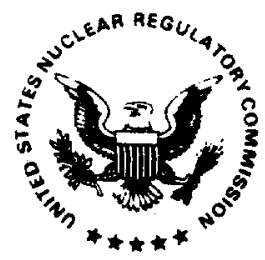

UNITED STATES

\section{NUCLEAR REGULATORY COMMISSION}

WASHINGTON, D.C. 20585-0001

NIS 261994

IA $94-017$

Daniel J. McCool

(HOME ADORESS DELETED

UNDER 10 CFR 2.790)

SUBJECT: ORDER PROHIBITING INVOLVEMENT IN NRC-LICENSED ACTIVITIES (EFFECTIVE IMMEDIATELY)

The enclosed Order is being issued because of your violations of 10 CFR 30.10 of the Commission's regulations as described in the Order.

Based on an investigation conducted by the Nuclear Regulatory Commission's Office of Investigation, the NRC Staff has determined that you deliberately conspired with other AMSPEC officials to deceive the Commission and provided false testimony, under oath, to NRC officials. In addition, you deliberately failed to train and certify employees in radiation safety as required by the AMSPEC license conditions. A copy of the synopsis of the investigation is enclosed.

Failure to comply with the provisions of this Order may result in further civil or criminal sanctions.

Questions concerning this Order should be addressed to Mr. James Lieberman, Director, Office of Enforcement, who can be reached at (301) 504-2741.

In accordance with 10 CFR 2.790 of the NRC's "Rules of Practice," a copy of this letter and the enclosures will be placed in the NRC's Public Document Room.

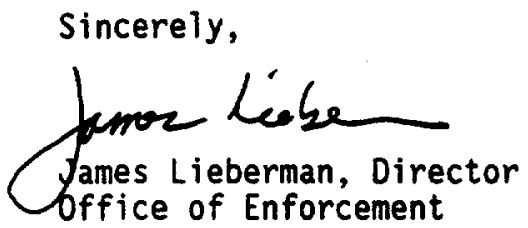

Enclosures:

1. Order

2. OI Synopsis 
UNITED STATES

NUCLEAR REGULATORY COMMISSION

In the Matter of

Daniel J. MeCool

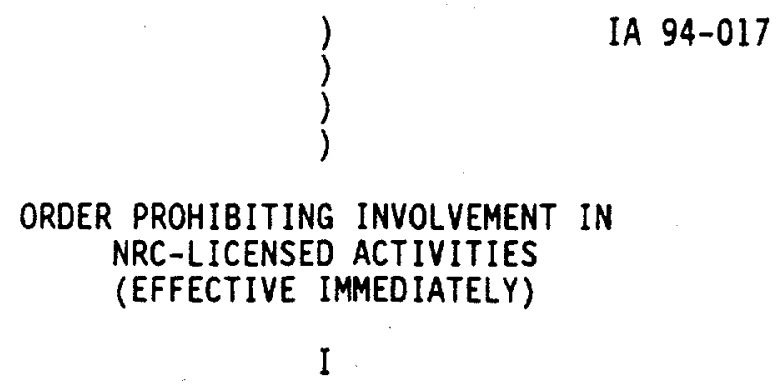

Daniel J. McCool has been employed as a radiographer in the field of industrial radiography since approximately 1968. On approximately January 1 , 1987, Mr. McCool initiated licensed activities at the American Inspection Company, Inc., (AMSPEC), in his capacity as President. AMSPEC held Materials License No. 12-24801-01 issued by the Nuclear Regulatory Commission (NRC or Commission) pursuant to 10 CFR Parts 30 and 34 . The license authorized the conduct of industrial radiography activities in accordance with specified conditions. On April 30, 1992, the license was suspended as a result of significant safety violations and related safety concerns. Mr. McCool was President of AMSPEC at the time of license suspension.

Between August 22, 1991 and November 12, 1992, the NRC Office of Investigations conducted an investigation of licensed activities at AMSPEC. During the course of this investigation, the AMSPEC license was suspended when a significant number of safety violations were identified. In addition, the investigation revealed that $\mathrm{Mr}$. McCool, in his capacity as President of AMSPEC, conspired with other AMSPEC officials to deceive the Commission 
regarding training of employees and, in addition, deliberately provided false sworn testimony to NRC officials.

AMSPEC submitted a Radiation Safety Manual as a part of its license application dated September 20, 1986. A part of this manual refers to employee training to satisfy the requirements of Appendix A of 10 CFR Part 34 . This manual was incorporated as a part of License Condition 17 of the AMSPEC license. In addition, 10 CFR 30.9 (a) requires, in part, that information provided to the Commission by a licensee, and information required by the Commission's regulations to be maintained by the licensee, shall be complete and accurate in all material respects. 10 CFR 30.10 (a) requires, in part, that any licensee or any employee of a licensee may not: (1) engage in deliberate misconduct that causes a licensee to be in violation of any rule, regulation, or limitation of any license, issued by the Commission, or (2) deliberately submit to the NRC information that the person submitting the information knows to be incomplete or inaccurate in some respect material to the NRC.

From 1990 through April 1992, Mr. McCool deliberately violated License Condition 17 by failing to train new Radiation Protection Officers (RPOS), and by allowing others to administer the RPO qualification process, including exams and certification, although this was contrary to the Radiation Safety Program established in the Radiation Safety Manual. For over two years, from late fall 1989 through April 1992, Mr. McCool failed to perform the radiation safety audit function required by the Radiation Safety Program. In addition to the above, Mr. McCool deliberately provided false information under oath to 
an investigator and an inspector on May 4, 1992, regarding training of an individual in order to qualify that individual for work as an RPO.

On September 22, 1993, Mr. McCool pled guilty to two felony violations of the Atomic Energy Act based on his violations of these requirements. The violations to which Mr. McCOol pled were: (1) conspiracy to violate the Atomic Energy Act, and (2) providing false information to the NRC.

\section{III}

Based on the above, Mr. McCool engaged in deliberate misconduct which caused the licensee to be in violation of the training requirements of License Condition 17 and 10 CFR 30.9. The NRC must be able to rely on licensees and their employees to comply with NRC requirements, including the requirements to train and certify employees in radiation safety and procedures and the requirement to provide information that is complete and accurate in all material respects. Mr. McCool's actions in deliberately causing AMSPEC to be in violation of NRC requirements regarding training and completeness and accuracy of information and his deliberate false statements to NRC officials in violation of 10 CFR 30.10 have raised serious doubt as to whether he can be relied on to comply with NRC requirements, including the requirement to provide complete and accurate information to the NRC. Mr. McCool's deliberate misconduct, including his false statement to Commission officials, cannot and will not be tolerated.

Consequently, I lack the requisite reasonable assurance that 1 icensed activities can be conducted in compliance with the Commission's requirements 
and that the health and safety of the public will be protected if Mr. McCool were permitted at this time to supervise or perform licensed activities in any area where the NRC maintains jurisdiction. Therefore, the public health, safety and interest require that $\mathrm{Mr}$. McCool be prohibited from engaging in NRC-licensed activities (including any supervising, training or auditing) for either an NRC licensee or an Agreement State licensee performing licensed activities in areas of NRC jurisdiction in accordance with 10 CFR 150.20 for a period of five years from the date of this order. In addition, for a period of five years commencing after completion of the five year period of prohibition, Mr. McCool is required to notify the NRC of his employment by any person or entity engaged in NRC-licensed activities to ensure that the NRC can monitor the status of Mr. McCool's compliance with the Commission's requirements and his understanding of his commitment to compliance. Furthermore, pursuant to 10 CFR 2.202, I find that the significance of the conduct described above is such that the public health, safety and interest require that this order be effective immediately.

\section{IV}

Accordingly, pursuant to sections $81,161 \mathrm{~b}, 161 \mathrm{i}, 182$ and 186 of the Atomic Energy Act of 1954, as anended, and the Commission's regulations in 10 CFR 2.202, 10 CFR 30.10, and 10 CFR 150.20, IT IS HEREBY ORDERED, EFFECTIVE IMMEDIATELY, THAT:

1. Daniel J. McCOol is prohibited for five years from the date of this Order from engaging in NRC-licensed activities. NRC-licensed activities are those activities that are conducted pursuant to a specific or 
general license issued by the NRC, including, but not limited to, those activities of Agreement State licensees conducted pursuant to the authority granted by 10 CFR 150.20. During this time period, Mr. McCool must also provide a copy of this Order to prospective employers who engage in NRC-licensed activities, at the time he accepts employment.

2. For a period of five years after the five-year period of prohibition has expired, Daniel J. McCool shall, within 20 days of his acceptance of each employment offer involving NRC-1icensed activities or his becoming involved in NRC-licensed activities, as defined in Paragraph IV.1 above, provide notice to the Director, Office of Enforcement, U. S. Nuclear Regulatory Commission, Washington, D.C. 20555, of the name, address, and telephone number of the employer or the entity where he is, or will be, involved in the NRC-licensed activities. In the first notification Mr. McCool shall include a statement of his comitment to compliance with regulatory requirements and the basis why the Commission should have confidence that he will now comply with applicable NRC requirements.

The Director, Office of Enforcenent, may in writing, relax or rescind any of the above conditions upon demonstration by Mr. McCool of good cause.

In accordance with 10 CFR 2.202, Daniel J. McCOol must, and any other person adversely affected by this Order may, submit an answer to this Order, and may request a hearing on this Order, within 20 days of the date of this Order. 
The answer may consent to this Order. Unless the answer consents to this Order, the answer shall, in writing and under oath or affirmation, specifically admit or deny each allegation or charge made in this order and shall set forth the matters of fact and law on which Daniel J. McCool or any other person adversely affected relies and the reasons as to why the Order should not have been issued. Any answer or request for a hearing shall be submitted to the Secretary, U.S. Nuclear Regulatory Commission, Attn: Chief, Docketing and Service Section, Washington, OC 20555. Copies also shall be sent to the Director, Office of Enforcement, U. S. Nuclear Regulatory Commission, Washington, DC 20555, to the Assistant General Counsel for Hearings and Enforcement at the same address, to the Regional Administrator, NRC Region II, 101 Marietta Street, N. W., Suite 2900, Atlanta, Georgia 30323, and to Daniel J. McCOol if the answer or hearing request is by a person other than Daniel J. McCool. If a person other than Daniel J. McCool requests a hearing, that person shall set forth with particularity the manner in which his or her interest is adversely affected by this Order and shall address the criteria set forth in 10 CFR $2.714(d)$.

If a hearing is requested by Daniel $\mathrm{J}$. McCool or another person whose interest is adversely affected, the Commission will issue an Order designating the time and place of any hearing. If a hearing is held, the issue to be considered at the hearing shall be whether this Order should be sustained.

Pursuant to 10 CFR 2.202(c)(2)(i), Daniel J. McCool or any other person adversely affected by this Order, may, in addition to demanding a hearing, at the time the answer is filed or sooner, move the presiding officer to set aside the immediate effectiveness of the Order on the ground that the Order, 
including the need for immediate effectiveness, is not based on adequate evidence but on mere suspicion, unfounded allegations, or error.

In the absence of any request for hearing, the provisions specified in Section IV above shall be final 20 days from the date of this order without further order or processing. AN ANSWER OR A REQUEST FOR HEARING SHALL NOT STAY THE IMMEDIATE EFFECTIVENESS OF THIS ORDER.

FOR THE NUCLEAR REGULATORY COMMISSION

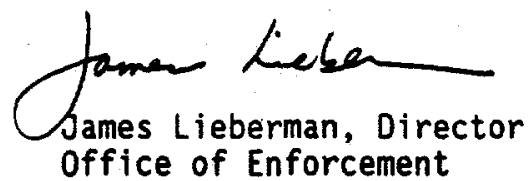

Dated at Rockville, Maryl and

this $26^{\text {th }}$ day of August 1994 
on August 22, 1991, the Regional Administrator, U.S. Nuclear Regulatory Commission (NRC), Region II, requested an investigation to determine whether officials, managers, and/or employees-of The American Inspection Company, Inc. (AMSPEC), the licensee, had intentionally violated regulatory and license condition requirements set forth in 10 CFR Parts 20,30 , and 34 and the NRC license of January 15, 1987, respectively. According to reported allegations, licensee management officials had permitted unqualified technicians to perform radiography operations at the Hess oil Virgin Islands Company (HOVIC) facility, St. Croix, U.S. Virgin Islands, which had contracted with AMSPEC for nondestructive examination services. Additionally, licensee officials allegedly: (1) discriminated (involuntary termination) against technicians for reporting radiation health and safety concerns, (2) falsified radiation safety training documents, (3) provided false and misleading information to the NRC, and (4) used source material in a manner not authorized by the license (irradiation of mice).

The office of Investigations (OI) reviewed the circumstances of the alleged regulatory and license condition violations during which other improprieties by the licensee were identified. The investigation by oI did not substantiate that licensee management officials had terminated radiography technicians for reporting radiation health and safety concerns. It was concluded, however, that these licensee officlals at the HOVIC facility appeared insensitive to employee concerns of all topics, including radiation safety, and they were perceived by technicians as acting with apparent disregard concerning this issue. The investigation further determined that licensee officials deliberately provided false and misleading radiation safetyrelated information to NRC representatives which was pertinent to the regulatory process. The investigation substantiated that the licensee, through actions of some radiation protection officers (RPOS), deliberately falsified radiation safety training records, inserted false records in technician files to give the impression required training was accomplished, and they also conspired to conceal these training deficiencies and improprieties frow the NRC. The investigation surfaced and substantiated the allegation that licensee offlcials and RPOs deliberately falsified required personnel radiation safoty audits and accompanying reports and they also created audit reports to make complete the radiation safety files of some technicians.

The investigation also disclosed and confirmed numerous instances of radiographers' assistants performing radiography without supervision and the deliberate falsilication of source utilization logs to give the appearance that required supervision was present, all with the apparent knowledge and concurrence of ilcensee management officials.. It was also determined during the investigation that licensee training offlcials (RPOs) frequently

Case No. 2-91-010R

NUREG-0940, PART I A-156 
failed to provide the operation and Emergency procedures (O\&EP) Manual to new employees prior to source utilization. The investigation also determined that some licensee RPOs were not trained, examined, and certified according to Radiation safety Programi requirements and AMSPEC officials, including the radiation safety officer (RSO) and several RPOs, were aware of some of these violations and failed to correct them. Further, on at least one occasion, the RSO and an RPO conspired to concoct a plausible explanation for the NRC as to why RPO examination/certification requirements were violated.

The investigation substantiated the allegation that radioactive source material was utilized improperly when an AMSPEC night shift supervisor, in the presence of technicians, radiographed a mouse during two to three consecutive source exposures at the HOVIC facility. The OI investigation, and a previous NRC inspection at the st. Croix location, also revealed instances in which AMSPEC technicians failed to observe required surveying and posting activities during radiography operations, actions which demonstrated either an apparent disregard for regulations and/or radiation safety training deficiencies. Finally, the investigation disclosed that the RSO and other Iicensee management officials deliberately failed to perform required radiation safety review, evaluation, and oversight functions and responsibilities during the past 3 years. 


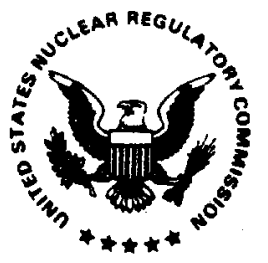

\section{UNITED STATES \\ NUCLEAR REGULATORY COMMISSION \\ WASHINGTON, D.C. 20665-0001}

March 27, 1996

IA $96-018$

Mr. Donald J. McDonald, Jr.

(HOME ADORESS DELETED

UNDER 10 (FR 2.790)

SUBJECT: OROER PROHIBITING INVOLVEMENT IN NRC-LICENSED ACTIVITIES

(EFFECTIVE IMMEDIATELY)

(NRC OFFICE OF INVESTIGATIONS REPORT NO. 3-95-007)

Dear Mr. McDonald:

The enclosed Order is being issued as a result of an investigation by the NRC office of Investigations (OI) which concluded that you deliberately provided incomplete and inaccurate information on applications you made for access authorization at Illinois Power Company's (1icensee) Clinton Power Station. A copy of the OI Synopsis is enclosed. The Order prohibits your involvement ins NRC-licensed activities, and your obtaining unescorted access to protected and vital areas of facilities 1 icensed by the NRC, for a period of three years from the date of the order. In addition, for your first acceptance of employment in NRC-licensed activities after the three year period of prohibition has expired, the Order requires you to notify the NRC of your acceptance of such employment and requires you to certify that you will comply with NRC requirements in engaging in such activities.

On March 22, 1994, you indicated on your background screening questionnaire for Clinton Power station that you had not been arrested or convicted of a criminal offense other than a driving while under the influence (DWI) conviction. However, unescorted access was not pursued further at the time. You completed a second questionnaire on November 3, 1994, in which you listed no criminal history. After submitting your fingerprint cards to the Federal Bureau of Investigations, the licensee was informed that you had a criminal record of three convictions. Furthermore, it was learned that you had not achieved the educational level that you claimed in your application. 10 CFR $50.5(a)(2)$, "Deliberate Misconduct," prohibits an employee of a licensee contractor from deliberately submitting information to the 1 icensee that the employee knows to be incomplete or inaccurate in some respect material to the NRC. The incomplete information you deliberately provided regarding your criminal history is a violation of 10 CFR 50.5 (a) (2). Information concerning criminal history and educational history is material to the determination the licensee must make in granting or denying unescorted access pursuant to 10 CFR $73.56(b)(2)$.

Pursuant to section 223 of the Atomic Energy Act of 1954, as amended, any person who will fully violates, attempts to violate, or conspires to violate, any provision of this order shall be subject to criminal prosecution as set forth in that section. Violation of this order may also subject the person to civil monetary penalty. 
During a telephone conversation with Paul Pelke, NRC Region III, on February 15, 1996, you declined an opportunity to participate in a predecisional enforcement conference on this matter. You are required to respond to this Order and should follow the instructions specified in Section $V$ of the Order when preparing your response. Questions concerning this Order should be addressed to James Lieberman, Director, Office of Enforcement, who can be reached at (301) 415-2741.

In accordance with 10 CFR 2.790 of the NRC's "RuTes of Practice," a copy of this letter and its enclosures will be placed in the NRC Public Document Room (PDR).

Sincerely,

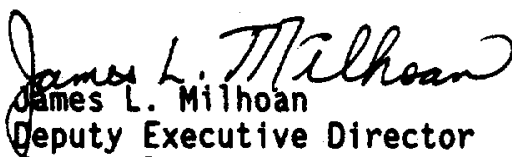

for Nuclear Reactor Regulation, Regional Operations, and Research

Enclosures: As Stated

cc w/enc1: The National Board of Boiler and Pressure Vessel Inspectors

Commercial Union Contract Inspection Services

R. Morgenstern, Pl ant Manager, Clinton Power Station 
UNITED STATES

NUCLEAR REGULATORY COMMISSION

In the Matter of

Donald J. McDonald, Jr.

$$
\{
$$

IA 96-018

ORDER PROHIBITING INVOLVEMENT IN

NRC-LICENSED ACTIVITIES

(EFFECTIVE IMMEDIATELY)

\section{I}

Mr. Donald J. McDonald, Jr., was employed as an Authorized Nuclear In-service Inspector for Factory Mutual Engineering, which is owned by Arkwright Mutual Insurance Company, Inc., a contractor of the Illinois Power Company (Licensee). Licensee is the holder of License No. NPF-62 issued by the Nuclear Regulatory Commission (NRC or Commission) pursuant to 10 CFR Part 50 on Apri1 17, 1987. The license authorizes the operation of Clinton Power Station (facility) in accordance with the conditions specified therein. The facility is located on the Licensee's site in Clinton, Illinois.

II

Mr. McDonald first applied for unescorted access to the Clinton Power Station by completing a background screening questionnaire on March 22, 1994. In response to a question on the questionnaire as to whether he had ever been convicted of a felony or misdemeanor, he listed one driving while under the influence conviction (DWI). However, unescorted access was not pursued further at the time. Mr. McDonald completed a second background screening questionnaire on November 3, 1994, in which he listed no criminal history in 
response to the same question. Subsequently, the Licensee submitted fingerprint cards to the Federal Bureau of Investigations (FBI) and was informed that Mr. McDonald had a record of three convictions. Illinois Power Company denied Mr. McDonald unescorted access to the Clinton Power Station. The investigation also determined that Mr. McDonald had falsified his educational record.

The NRC Office of Investigations conducted a transcribed interview of Mr. McDonald on November 30,1995 . When asked by the NRC Investigator about the failure to list the convictions on the background screening questionnaires, Mr. McDonald admitted that he knowingly provided inaccurate and incomplete information.

Based on the above, Mr. McDonald engaged in deliberate misconduct on March 22, 1994, and November 3, 1994, in that he deliberately provided incomplete and inaccurate information on two different access authorization applications. The Conaission's regulations in 10 CFR 50.5, in part, prohibit any employee of a contractor of a licensee from deliberately submitting to the licensee information that the coployee knows to be incomplete or inaccurate in some respect material to the NRC. Information concerning criminal history and educational history is material to the determination the licensee must make in granting or denying unescorted access to its facility pursuant to 10 CFR 73.56(b)(2). Mr. MCDonald's actions constituted a violation of 10 CFR $50.5(a)$. 
The NRC must be able to rely on the Licensee, its contractors, and contractor employees to comply with NRC requirements, including the requirement to provide information that is complete and accurate in all material respects. Mr. McDonald's actions in deliberately providing incomplete and inaccurate information to the Licensee constituted deliberate violations of Commission regulations and raised serious doubt as to whether he can be relied upon to comply with NRC requirements and to provide complete and accurate information to the NRC in the future.

Consequently, I lack the requisite reasonable assurance that licensed activities can be conducted in compliance with the Commission's requirements and that the health and safety of the public will be protected if Mr. McDonald were permitted at this time to be involved in NRC-1icensed activities or were permitted unescorted access to protected or vital areas of NRC-licensed facilities. Therefore, the public health, safety and interest require that Mr. McDonald be prohibited from any involvement in NRC-licensed activities and be prohibited from obtaining unescorted access for a period of three years from the date of this Order and, if Mr. McDonald is currently involved with an employer in NRC-licensed activities, he must immediately cease such activities, inform the NRC of the name, address and telephone number of the employer, and provide a copy of this order to the employer. Additionally, for his first acceptance of an employment offer involving NRC-licensed activities or the assumption of duties in an existing job involving NRC-licensed activities following the three year period of prohibition, Mr. McDonald shall provide notice to the NRC within 20 days of the acceptance of the name, address, and telephone number of the employer or the entity where he is, or 
will be, involved in the NRC-licensed activities, and certify that he will comply with NRC regulatory requirements in such employment. Furthermore, pursuant to 10 CFR 2.202, I find that the significance of Mr. McDonald's conduct described above is such that the public health, safety and interest require that this Order be immediately effective.

Accordingly, pursuant to sections 103,161b, $161 \mathrm{i}, 182$ and 186 of the Atomic Energy Act of 1954, as amended, and the Commission's regulations in 10 CFR 2.202, and 10 CFR 50.5, IT IS HEREBY ORDERED, EFFECTIVE IMMEDIATELY, THAT:

1. (a) Mr. Donald J. McDonald, Jr., is prohibited from engaging in NRClicensed activities and from obtaining unescorted access to protected and vital areas of facilities licensed by the NRC for a period of three years from the date of this order. For the purposes of this Order, licensed activities include the activities licensed or regulated by: (1) NRC; (2) an Agreement State, limited to the 1icensee's conduct of activities within NRC jurisdiction pursuant to 10 CFR 150.20; and (3) an Agreement State where the licensee is involved in the distribution of products that are subject to MRC jurisdiction.

(b) If Mr. McDonald is currently involved in NRC-licensed activities with an employer, he shall immediately cease such activities, inform the 
NRC of the name, address and telephone number of the employer, and provide a copy of this Order to the employer.

2. Following the three year period of prohibition, at the time of his first acceptance of an employment offer involving NRC licensed activities as defined in Paragraph IV.1 above, or the first assumption of duties in an existing job that involve licensed activities, Mr. McDonald shall provide notice to the NRC within 20 days of the acceptance or assumption of duties of the name, address, and telephone number of the employer or the entity where he is, or will be, involved in the NRC-licensed activities. This notice (a) shall be provided to the Director, Office" of Enforcement, U. S. Nuclear Regulatory Commission, Washington, D.C. 20555, and (b) shall certify Mr. McDonald's commitment to compliance with regulatory requirements and provide the basis as to why the Commission should have confidence that Mr. McDonald will now comply with applicable NRC requirements.

The Director, OE, may, in writing, relax or rescind any of the above conditions upon demonstration by Mr. McDonald of good cause.

In accordance with 10 CFR 2.202, Mr. McDonald must, and any other person adversely affected by this Order may, submit an answer to this Order, and may request a hearing on this Order, within 20 days of the date of this Order. Where good cause is shown, consideration will be given to extending the time 
to request a hearing. A request for extension of time must be made in writing to the Director, Office of Enforcement, U.S. Nuclear Regulatory Comission Washington, D.C. 20555, and include a statement of good cause for the extension. The answer may consent to this Order. Unless the answer consents to this Order, the answer shall, in writing and under oath or affirmation, specifically admit or deny each allegation or charge made in this order and shall set forth the matters of fact and law on which Mr. McDonald or other person adversely affected relies and the reasons as to why the Order should not have been issued. Any answer or request for a hearing shall be submitted to the Secretary, U.S. Nuclear Regulatory Commission, Attn: Chief, Docketing and Service Section, Washington, $O C$ 20555. Copies also shall be sent to the" Director, Office of Enforcement, U.S. Nuclear Regulatory Commission, Washington, $D C$ 20555, to the Assistant General Counsel for Hearings and Enforcement at the same address, to the Regional Administrator, NRC Region III, 801 Warrenville Road, Lisle, IL 60532-4351, and to Mr. McDonald if the answer or hearing request is by a person other than Mr. McDonald. If a person other than Mr. McDonald requests a hearing, that person shall set forth with particularity the manner in which his interest is adversely affected by this Order and shall address the criteria set forth in 10 CFR 2.714(d).

If a hearing is requested by Mr. McDonald or a person whose interest is adversely affected, the Comission will issue an Order designating the time and place of any hearing. If a hearing is held, the issue to be considered at such hearing shall be whether this order should be sustained. 
Pursuant to 10 CFR 2.202(c)(2)(i), Mr. MCDonald, or any other person adversely affected by this order, may, in addition to demanding a hearing, at the time the answer is filed or sooner, move the presiding officer to set aside the imnediate effectiveness of the Order on the ground that the Order, including the need for immediate effectiveness, is not based on adequate evidence but on mere suspicion, unfounded allegations, or error.

In the absence of any request for hearing, or written approval of an extension of time in which to request a hearing, the provisions specified in Section IV above shall be final 20 days from the date of this Order without further order or proceedings. If an extension of time for requesting a hearing has been approved, the provisions specified in Section IV shall be final when the extension expires if a hearing request has not been received. AN ANSWER OR A REQUEST FOR HEARING SHALL NOT STAY THE IMMEDIATE EFFECTIVENESS OF THIS ORDER.

FOR THE NUCLEAR REGULATORY COMMISSION

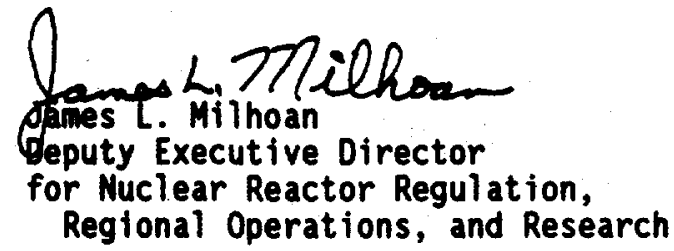

Dated at Rockville, Maryl and this $27^{\text {thday }}$ of March 1996 


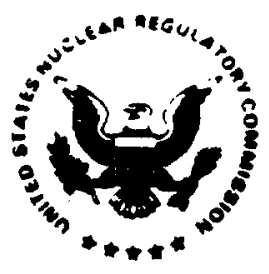

UNITED STATES

\author{
NUCLEAR REGULATORY COMMISSION \\ WASHINOTON, O.C. 20000001
}

\title{
N14 281904
}

Docket No. 55-60117

License Ho. SOP-11160

IA 94-014 and EA 94-094

Mr. Stephen Mignotte

[HOME ADORESS DELETED

UNDER 10 CFR 2.790]

Dear Mr. Mignotte:

SUBJECT: NOTICE OF VIOLATION AND ORDER PROHIBITING IMVOLVENENT IN 10 CFR PART 55 LICENSED ACTIVITIES (EFFECTIVE IMUEDIATELY)

The Nuclear Regulatory Comission (NRC) has received a letter dated December 23, 1993 fro the New York Power Authority, Inforing us that it no longer has a need to eaintain your operating license for the Indian Point Unit 3 Muclear Power plant. We al so received a letter dated January 3, 1994 (the letter is actually dated January 3, 1993, but due to the content of the letter, it is apparent that the correct date is January 3, 1994) from the fiew York Power Authority containing information concerning the circusstances associated with your confirned positive test for art Juana and cocatne during a randou drug test conducted at the factilty on Novecber 23, 1993. The test was conducted in accordance with fitness-for-duty requireannts. We plan to place both of these letters in your 10 CFR Part 55 docket f1le.

In accordance with 10 CFR $55.55(a)$, the dotermination by your facllity iicensee that you no longer need to maintain a itcense has caused your license SOP-11160 to expire as of Decaber 23, 1993. A Notice of Violation is being issued to you for your fallure of the chealcal test, your performance of ifcensed duttes witle under the influence of 111 egal drugs, and your subaisston of inaccurate inforation in the form of a false urine sample.

The purpose of the Conission's Fitness-for-Duty requireants is to provide reasonable assurance that nuclear power plant porsonnel work in an environanent that is free of drugs and alcohol and the effects of the use of these substances. The use of $111 \mathrm{egal}$ drugs is a serfous atter that underwines the special trust and confidence placed in you as a licensed operator. The violations relating to the cheafcal test fallure were categorized as a Severity Leval III proble in accordance with the "General statement of Policy and Procedure for Mix Enforcement Actions", 10 CFR Part 2, Appendix $C$ (Policy) because the use of 11 legal drugs by licensed operators is a significant regulatory concern.

The violation relating to the subatssion of a false urine saple is of signifteant concern to the MRC because it indicates a willingness on your part to subvert the purpose of the facility 1 icensee's fitness-for-duty progran by deliberate violation of $10 \mathrm{CFR} 55.53(\mathrm{k})$ and by deliberately providing 
Inaccurate and incomplete information to the licensee in violation of 10 CFR $50.5(2)(1)$ and $(2)$. This violation was also categorized as a Severity Level III violation in accordance with the policy.

Because your license has explred, you are not required to respond to the Notice of Violation at this tim unless you contest the violations. Should you contest the violations, a response is required within 30 days of the date of this letter addressing the specific basis for disputing the violation. This response should be sent to the Regional Adainistrator, NRC Region I, $U$. S. Nuclear Regulatory Comission, 475 Allendale Road, King of Prussta, PA 19406.

The purpose of this letter is to make clear to you the consequences of your violation of MRC requiteants governing fitness-for-duty as a licensed operator, in accordance with 10 CFR Part 55. Although you resigned your position at Indian Point 3 on November 23, 1993, the MRC reasalns concerned about the circunstances surrounding your urine test. The teaperature of the first urine saple you provided was below the linits to be expected from a fresh urine saple and that saple ytelded a negative test result. Due to the temperature of the saple, howver, you were required to supply another sample, which was witnessed to ensure that it was a genuine sample, and this saple yielded a positive test result. The temperature of the first saple and the different results of the two saples taken close in time indicate that the first saple was not genuine and is ovidence that you supplied a surrogate sample in an atteopt to avold detection for the use of 111 legal drugs. This attempt to subvert the testing process is a violation of $10 \mathrm{CFR} 55.53(k)$, as well as 10 CFR $50.5(a)(1)$ and (a)(2), and deconstrates an intentional disregard for the ieportant obilgations of a licensed operator. In addition, the positive test result constitutes a violation of the conditions of your Ilcense prohibiting any use of 11 legal drugs, by the terns of 10 CFR $55.53(\mathrm{j})$. Therefore, an Ordar is also baing issued prohibiting your involveant in 10 CFR Part 55 licensed activities for a pertod of three years from the date of the Order.

Faflure to comply with the provisions of the enclosed Order way result in civil or criminal sanctions. Questions concerning this order should be addressed to Jaens Lieberaan, Otrector, Offtce of Enforcewent, who can be reached at $(301)$ so4-2141.

If, after the tice period spectified in the Order, you reapply for an operating license, you will need to sat lsfy not only the requireaents of 10 CFR 55.31, but also those of $10 \mathrm{CFR}$ 2.201, by addressing the reasons for the violations and the actions you have taken to prevent recurrence in order to ensure your ability and wlllingness to carry out the special trust and confidence placed in you as a itcensed operator and to abide by all fitness-for-duty and other ilcense requitreants and conditions.

In accordance with Section 2.790 of the NRC's "Rules of Practice," Part 2 , Title 10, Code of Federal Regulations, enforcewent actions are placed in the MRC Public Document Room (POR). A copy of this letter with its enclosures but

NUREG-0940, PART I A-168 
with your address renoved w111 be placed in the POR. The letters fron New York Power Authorlty, dated December 23, 1993 and January 3, 1994, will not be placed in the POR.

$$
\text { Sincerely, }
$$

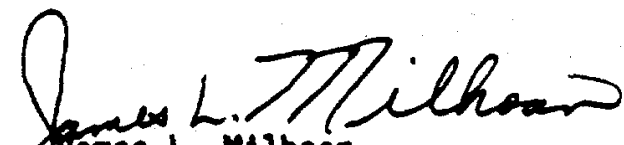

sares L. Milinoan

Deputy Executive O1rector for

Nuclear Reactor Regulation.

Regtonal Operations, and Research

\section{Enclosuras:}

1. Order Prohibiting Involvement

in 10 CFR Part 55 Licansed Activities

(Effective Inediately)

2. Nottce of Violation

3. Decewber 23, 1993 letter from NYPA

4. January 3, 1994 letter froa IYPA

cC $⿴ /$ encl:

Resident Managor, IP-3 


\section{UNITED STATES \\ NUCLEAR REGULATORY COMISSION}

In the Matter of

STEPHEN MIGNOTTE

Sentor Reactor Operator

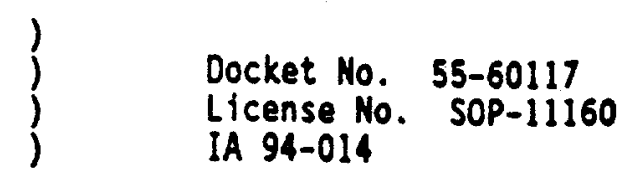

ORDER PROHIBITING INVOLVEMENT

IN 10 CFR PART 55 LICENSED ACTIVITIES

(EFFECTIVE IMAEDIATELY)

I

Stephen Mignotte (Mr. Mignotte) held Senfor Reactor Operator License Mo. SOP11160 (LICense) issued by the Nuclear Regulatory Comission (MRC or Comission) pursuant to 10 CFR Part 55. The license authorized Mr. Mignotte to anipulate, and to supervise the manipulation of, the controls of the nuclear power reactor at the New York Power Authority's (Facllity Licensee) Indian Point 3 Nuclear Power Plant in Buchanan, Now York. On Novewber 23, 1993, Mr. Mignotte resigned his exployment with the Mew York Pown Authority, wich caused the License to expire. Additionally, the Factlity Licensee, in a letter dated December 23, 1993, Inforwed the MRC that the New York Power Authority no longer had a need to eaintain Mr. Mignotte's operating license for the Indtan Point Unit 3 Nuclear Power Plant.

The responsfbilities asseciated with a Senfor Reactor Operator Ificense issued pursuant to 10 CFR Part 55 require that individuals be fit for duty while perforaing safoty-related activities at the factlity. The character of the individual, which includes the individual's trustworthiness, is a 
consideration in Issuing an operator license. See Section 182a of the Atomic Energy Act of 1954, as amended (42 U.S.C. 2232a). In deternining whether or not an individual seeking a license to be a reactor operator or senfor reactor operator has the necessary character and trustworthiness, the Comatssion takes into account any history of 11 legal drug use by the applicant. Prier to May 26, 1987, each applicant for a reactor operator or senfor reactor operator license was required to certify that the applicant had no drug or narcotic habit on the Certificate of Medical Exanination, MRC Form 396 . Since that ties, the MRC has required an evaluation of the applicant prepared by a phystcian as part of a license application. See 10 CFR 55.23(a). This evaluation is presented on a Cortificate of Madical Exanination, MRC Form 396. Se 10 CFR 55.23. Anong the factors to be considerad by the certifying phystctan are factors such as use of 111 legal drugs or abuse of alcohol. See Form 396; seenlso MSI/NS 3.4-1983, Section 5.2.2.

In accordance with 10 CFR Part 26, the Facility Licensee established a progran to provide reasonable assurance that nuclear power plant personnel are not under the influence of any substance, legal or 11legal, which affects thetr abllity to safoly and comptently perform thetr duties, including measures for early detection of parsens tho are not fit to perform 11censed activities. In addition, Itcensed operators are required by 10 CFR $55.53(j)$ to refratn from use of illegal drugs, Including marijuana and cocaine. Llcensed operators are also required by 10 CFR $55.53(k)$ to partfcipate in 10 CFR Part 26 fitness-forduty programs established by the Factilty Licensees. 
On November 23, 1993, Mr. Mignotte, whlle on duty as a Senior Reactor Operator at the Indian Point 3 facility, was requested by the facility licensee to provide a urine sample to the nurse at the plant after being randomly selected as part of the routine fitness for duty chentcal testing progran required of the Factlity Licensee by the MRC pursuant to 10 CFR 26.24. After receiving a sample from Mr. Mignotte, the nurse checked the temperature of the saple, noticed that it felt "cool to the touch", and found that the temperature was below speciffcations in 10 CFR Part 26, Appendix A, Section 2.4(g)(14), for acceptable urine saples. As a result, Mr. Mignotte was requested to provide a witnessed urine saple to the facility Licensee in accordance with the sane section of the Appendix. Mr. Mignotte provided a second saple wich was subsequently determined, on Noverber 30, 1993, to contain both arijuana and cocaine above cutoff levels specifled by the Appendix. After the witnessed urine sample had been collected on November 23, 1993, Mr. Mignotte was suspended from licensed duties and he subsequently resigned that same day. These facts were provided to the MRC by the Facility Licensee, in letters dated December 23, 1993 and January 3, 1994, and wre discussed in the report of an MRC inspection conducted January 12-13, 1994.

The results of the second, witnessed urine saple indicate that Mr. Mignotte used illegal drugs, which is a violation of the conditions of his license imposed by 10 CFR 55.53(j). Furthernore, his performance of licensed duties while under the influence of Illegal drugs is also a violation of the conditions of his license leposed by 10 CFR 55.53(J). Based on the 
temperature of the first urine sample provided by Mr. Mignotte and the fact that the first saple ylelded negative results when tested for lllegal substances while the subsequent, witnessed sample yielded positive results, I conclude that the first sample was a surrogate false sample, submitted by Mr. Mignotte in an attempt to conceal fllegal drug use.

10 CFR 50.5(a)(2) prohibits any employee of a licensec fron dellberately subaltting to the MRC, a licensee, or a licensee's contractor or subcontractor, information that the person subaitting the information knows to be incomplete or Inaccurate in som respect eaterial to the MRC. The urine saples collected within the context of a licensee's cheaical testing progran pursuant to the requirements of 10 CFR Part 26 represent information eaterial to an access authorization and fitness-for-duty dectsion. Therefore, Mr. Mignotte's deliborately subaitting inaccurate inforation aterial to the MRC in the form of a false saple, is a violation of 10 CFR 50.5(a)(2). In addition, Mr. Mignotte violated 10 CFR $50.5(a)(1)$ by deliberately providing to the Facflity Licensee a surrogate urine saple that he knew to be inaccurate at the tise he subaitted it and which, but for detection, would have caused the Facility Licenses to be in violation of 10 CFR 50.9(2).

Mr. Mignotte's fallure to comply with the prohibition agatnst 1 llegal drug use and his atterpts to circurvent the chealcal testing progran to avoid detection of illegal drug use mille exployed by the facility Licensee are violations of the conditions of Mr. Mignotte's Iicense laposed by 10 CFR $55.53(j)$ and $(k)$, and demonstrate an intentional disregard for the important obligations of a licensed operator. 
Based on the above, Mr. Mignotte, an exployee of the New York Power Authority at the time of the incident, engaged in deliberate aisconduct in violation of 10 CFR $50.5(2)(1)$ and (2) by dellbarately violating 10 CFR 55.53(k), In that he subaitted to the facility licensee information which he knew to be inaccurate in som respect material to the MRC. Mr. Mignotte, a licensed Senfor Reactor Operator at the tiw of the event, also used lllegal substances and performed licensed duties wille under the influance of lllegal substances in violation of 10 CFR $55.53(\mathrm{~J})$, and deliberately falled to participate in the fitness-for-duty progran established by the factlity licensee in violation of 10 CFR $55.53(k)$.

The MAC wust be able to roly on its licensees and their employees, espectally MRC-licensed operators, to caply wth MAC requirements, including the requirement to provide information and asintain records that are complete and accurate in all matorial respects. Mr. Mignotte's actlons in using 11 legal drugs and attempting to circument fitness-for-duty requireants have raised serfous doubt as to wather he can be relled upon to comply with MRC requirements applicable to licensed individuals and to provide complete and accurate information to the MRC.

Consequently, I lack the requisite reasonable assurance that Mr. Mignotte will conduct any 10 CFR Part 55 licensed activities in compliance with the Comission's requireants and that the health and safoty of the public will be 
protected with Mr. Mignotte engaged in such licensed activities at this time. Therefore, I find that the public health, safety, and interest require that Mr. Mignotte be prohibited froa involvement in 10 CFR Part 551 icensed activities for three years from the date of this Order. Furthermore, pursuant to 10 CFR 2.202, I find that the significance of the atsconduct described above is such that the public health, safety and interest require that this Order be inediately effective.

Accordingly, pursuant to sections 103, 107, 161b, 1611, 1610, 182 and 186 of the Atoaic Enorgy Act of 1954, as anded, and the Comission's regulations in. 10 CFR 2.202, 10 CFR 50.5, and 10 CFR 55.61, IT IS HEREBY ORDERED, EFFECTIVE IMEEDIATELY, THT:

A. Mr. Mignotte is prohibited for three years from the date of this Order from engaging in licensed operator activities licensed by the MRC pursuant to 10 CFR Part 55.

B. For a parted of three years from the date of this Order, Mr. Mignotte shall provide a copy of this Order to any prospective coployer angaged in activities licensed by the MRC pursuant to 10 CFR Part 50 prior to his acceptance of exploymant with such prospective enployer so that the employer wtll have nottce of the prohibition against Mr. Mignotte's involvement in licensed operator activitfes licensed pursuant to 10 CFR Part 55. 
C. For three years from the date of this Order, Mr. Mignotte shall provide notice to the Oirector, Office of Enforcenent, U.S. Nuclear Regulatory Commission, Washington, DC 20555, of the name, address, and telephone number of the employer, within 72 hours of his acceptance of an employment offer, from an employer who is engaged in activities 1 fcensed by the MRC pursuant to 10 CFR Part 50.

The Director, Office of Enforcement may, in writing, relax or rescind any of the above conditions upon demonstration by Mr. Mignotte of good cause.

In accordance with 10 CFR 2.202, Mr. Mignotte mist, and any other person adversely affected by this Order may, subait an answer to this Order, and may request a hearing within 20 days of the date of this Order. The answer way consent to this Order. Uniess the answer consents to this Order, the answer shall, in writing and under oath or affirmation, specifically adait or deny each allegation or charge ande in this Order and shall set forth the matters of fact and law on wich Mr. Mignotte or other person adversely affected. relies and the reasons as to why the Order should not have been issued. Any answer or request for a hearing shall be subaltted to the Secretary, U. S. Nuclear Regulatory Comission, ATTH: Chief, Docketing and Service Section, Washington, $D C$ 20555. Copies also shall be sent to the Director, Office of Enforcenent, U. S. Muclear Regulatory Comission, Nashington, OC 20555; to the 
Assistant General Counsel for Hearings and Enforcement at the same address; to the Regional Adainistrator, Region I, U. S. Nuclear Regulatory Comission, 475 Allendale Road, King of Prussia, PA 19406; and to Mr. Mignotte, if the answer or hearing request is by a person other than Mr. Mignotte. If a person other than Mr. Mignotte requests a hearing, that person shall set forth with particularity the anner in which his interest is adversely affected by this Order and shall address the criterla set forth in 10 CFR 2.714(d).

If a hearing is requested by $\mathrm{Mr}$. Mignotte or a person whose interest is adversely affected, the Comisston will issue an Order designating the tim and place of any hearing. If a hearting is held, the issue to be considered at such hearing shall be mother this Order should be sustalned.

Pursuant to 10 CFR 2.202(c)(2)(1), Mr. Mignotte or any person adversely affected by this Order, ay, in addition to deanding a hearing, at the time that answer is flied or sooner, wove the presiding officer to set aside the imediate effectiveness of the Order on the ground that the Order, including the need for inadiate offectiveness, is not based on adequate evidence but on nere suspicion, unfounded allegations, or error.

In the absence of any request for a hearing, the provisions specified in Section IV above shall be final 20 days from the date of this Order without 
further order or proceedings. AN ANSWER OR A REQUEST FOR A HEARING SHALL HOT STAY THE IMEDIATE EFFECTIVENESS OF THIS ORDER.

FOR THE NUCLEAR REGULATORY COMISSION

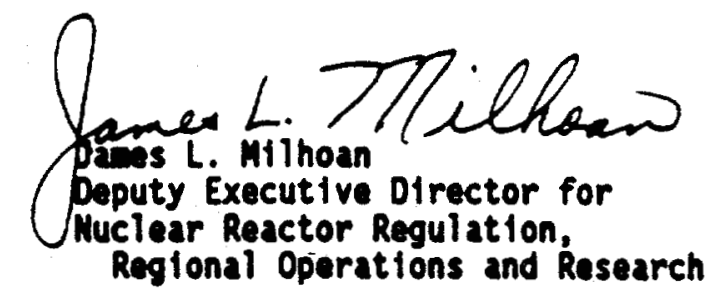

Dated at Rockville, Maryl and

this 28 day of June 1994 


\section{MOTICE OF VIOLATION}

Stephen Mignotte

Senfor Reactor Operator
Docket No. 55-60117

Llcense No. SOP-11160

EA $94-094$

In letters from the New York Power Authority dated December 23, 1993 and January 3, 1994, and during an inspection conducted by the MRC on January 1213, 1994, violations of NRC requirements were identified. In accordance with the "General Statement of Policy and Procedure for MRC Enforcement Actions," 10 CFR Part 2, Appendix $C$, the violations are listed below:

A. 10 CFR 55.53(j) prohibits the use of 11 legal drugs, including arrijuana and cocaine, and prohtbits the operator from perforaing activitfes authorized by a license issued under 10 CFR Part 55 while under the influence of marijuana or cocaine. "Under the Influence" is defined in 10 CFR 55.53(J) to man that the oporator "exceeded, as evidenced by a confirmed positive test, the lower of the cutoff levels for drugs or alcohol contained in 10 CFR Part 26, Appendix $A$, of this chapter, or as established by the facility licensee."

10 CFR 55.53(k) requires each 11 censee at power reactors to particlpate in the drug and alcohol testing prograns established pursuant to $10 \mathrm{CFR}$ Part 26.

1. Contrary to the above, the licensev violated 10 CFR $55.53(j)$ as ovidenced by the following exaples:

a. the licenses used marijuana and cocaine, as ovidenced by a conftrued positive test for these drugs from a urine sample subatited on Noverber 23, 1993; and

b. the 11censee perfornad 11censed duttes on November 23, 1993 inediately bafore the subalssion of the urine sample which indicated that the licensee was under the influence of marijuana and cocalne wile perforaing those duties. (01013)

2. Contrary to the above, the licensee violated 10 CFR $55.53(k)$ in that when he was selected for a rando test on November 23, 1993, he subatted a surrogate urine saple for testing. The low temperature of this first saple and the fact that it tested negative mitle an observed sample subaitted soon afterward tested positive for drugs is ovidence that the first sample was a surrogate. (01023)

This is a Severity Level III problea (Supplement I).

B. 10 CFR 50.9 (a) requires that information required by 1 icense conditions to be maintained by the Ilcensee shall be complete and accurate in all material respects. 
10 CFR 50.5(a)(1) prohibits an employee of a licensee from engaging in deliberate at sconduct that, but for detection, would have caused the ilcensee to be in violation of any rule, regulation, or order, or any term, condition, or liditation of any license.

10 CFR $50.5(a)$ (2) prohibits any employee of a 1 lcensee from subattting to a licensee information that the employee subaitting the information knows to be inaccurate in some respect material to the MRC.

Contrary to the above, in violation of 10 CFR $50.5(a)(1)$, Stephen Mignotte deliberately provided a surrogate urine saple to Mew York Power Authority, a Couisston licensee, as described in Violation A, above, which, if Mew York Power Authority had not detected that the saple was a surrogate saple, would have caused the licensee to be in violation of 10 CFR 50.9(a). In addition, Mr. Mignotte's action violated 10 CFR 50.5(a)(2) because the information to be darived frod that urine saple was material to the MRC in that it was required by 10 CFR Part 26. (02013)

This is a Soverity Level III violation (Supplement VII).

Because your license has explred, you are not required to respond to this Hotice of Violation at this tie iniess you contest the violntion. Should you contest the Notice of Violation, response is required within 30 days of the date of this Notice addrassing the spectfic basts for disputing the violation. This response should be sent to the Regional Adainistrator, MRC Reglon I, 475 Allendale Road, King of Prussta, PA 19406-1415.

Dated in Rockville, Maryland

this 28 tay of June 1994 


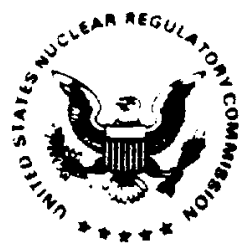

\section{UNITED STATES \\ NUCLEAR REGULATORY COMMISSION \\ WASHINGTON. D.C. 20555-0001}

APR $2 ! 1994$

IA $94-008$

Mr. Sean G. Miller

[Home Address Deleted

Under 10 CFR 2.790]

Dear Mr. Miller:

SUBJECT: ORDER PROHIBITING INVOLVEMENT IN NRC-LICENSED

ACTIVITIES (EFFECTIVE IMDEDIATELY)

(NRC Inspection Report No. 50-237/92033; 50-249/92033;

NRC Investigation Report No. 3-92-055R)

The enclosed order is being issued as a consequence of events which occurred during operation of the Dresden Nuclear station Unit 2 on September 18, 1992, and in violation of the Dresden Technical Specifications and Nuclear Regulatory Commission (NRC or Commission) regulations. The NRC conducted an inspection and an investigation of the event. The investigation by the NRC's office of Investigations (OI) concluded that on September 18, 1992, you deliberately violated or caused violations of NRC requirements and the Dresden Technical Specifications. A copy of the synopsis of the OI report was forwarded to you by letter dated November 4, 1993. You were invited to participate in an enforcement conference scheduled on this matter for November 17 , 1993, but you declined.

On September 18, 1992, a rod mispositioning incident occurred when a Nuclear station operator (NSO), a licensed operator, moved a control rod out of sequence during your shift as the qualified Nuclear Engineer (QNE). You noticed the error, and the NSO continued to move control rods in violation of station procedures, at your direction and without the knowledge or authorization of the station Control Room Engineer (SCRE), after which you informed the SCRE of the mispositioned rod. Subsequently, you, the SCRE, the NSO and the two nuclear engineers in training who were present during the incident agreed not to tell anyone else about the mispositioned rod incident. As a result, neither the mispositioned rod nor the subsequent deviation fron the planned control rod pattern were documented in the control room log, you falsified a Dresden Form 14-14C, and CECo management was not informed of the incident.

Your actions in connection with a deliberate attempt to conceal the september 18,1992 event caused CECo to be in violation of 10 CFR 50.9, "Completeness and Accuracy of Information", and the Dresden license conditions, including technical specifications, 
Mr. Sean G. Millex

and constituted a violation of 10 CFR 50.5(a), "Deliberate Misconduct". In addition, by directing the Nso to continue to move control rods, you violated 10 CFR 55.3.

NRC does not have the requisite reasonable assurance that licensed activities will be properly conducted in accordance with regulatory requirements, including the requirement to provide information that is complete and accurate in all material respects, with you involved in licensed activities. Consequently, after consultation with the Commission, I have been authorized to issue the enclosed order Prohibiting Involvement in NRC-Licensed Activities (Effective Immediately). Failure to comply with the provisions of this order may result in civil or criminal sanctions.

Questions concerning the order Prohibiting Involvement in RRCLicensed Activities (Effective Immediately) may be addressed to James Lieberman, Director, office of Enforcement. Mr. Lieberman can be reached at telephone number (301) 504-2741.

In accordance with $10 \mathrm{CFR} 2.790$ of the NRC's "Rules of Practice," a copy of this letter and the enclosure with your howe address removed will be placed in the NRC's Public Document Room.

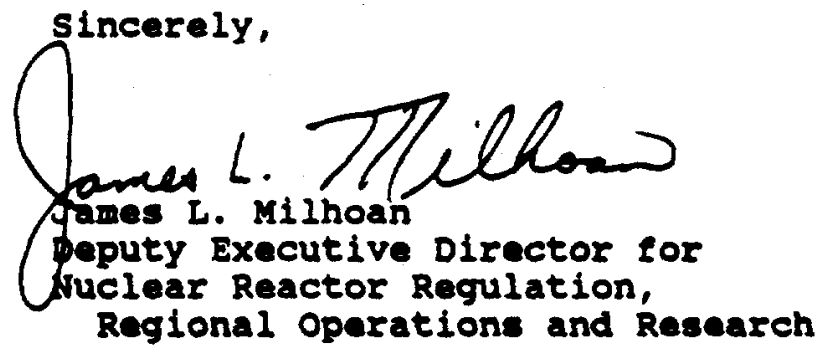

Enclosure: Order Prohibiting Involvement

in NRC-Licensed Activities (Effective Immediately)

cc w/anclosure:

w. J. Wallace, Vice President and Chief Nuclear officer

L. O. Delecorge, Vice President, Nuclear Oversight and Regulatory services

M. Lyster, site Vice President

G. Spedl, station Manager

$\mathrm{J}$. Shields, Regulatory Ascurance Manager

D. Farrar, Nuclear Regulatory Services Manager

Richard Hubbard

J. W. Mccaffrey, Chief Public Utilities Division

Robert Newmann, Office of Public Counsel

state of Illinois Center 
UNITED STATES

NUCLEAR REGULATORY COMYISSION

In the Matter of Sean G. Miller Coal City, Illinois

ORDER PROHIBITING INVOLVEMENT IN NRC-LICENSED ACTIVITIES (EFFECTIVE IMMEDIATELY)

I

Mr. Sean G. Miller was formerly employed by the Commonwealth Edison Company (CECO) from June 18, 1990, until he resigned his employment on December 2, 1992. He most recently held the position of Qualifled Nuclear Engineer (QNE) with responsibilities involving compliance with NRC requirements for the operation of a nuclear power plant. CECo holds Facility Licenses DPR-19 and DPR-25 issued by the Nuclear Regulatory Commission (NRC or Commisaion) pursuant to $10 \mathrm{CFR}$ Part 50. The Iicenses authorize CECo to operate the Dresden Nuclear station Units 2 and 3 located near Morris, Illinois. The licenses were issued by the NRC on December 22, 1969, and March 2, 1971, respectively.

\section{II}

On November 24, 1992, CECo notified the NRC that CECo senior managers had just becone aware of an incident that had occurred on September 18, 1992, when Unit 2 was operating at 75 power. A Nuclear station Operator (NSO), a licensed reactor operator, had incorrectly moved control rod $\mathrm{H}-1$ while repositioning control rods to change localized power levels within the reactor core, 
and the event was concealed from CECo management. Both CECo and NRC initiated an investigation of the incident.

On September 18, 1992, the NSO, a licensed operator, erroneously moved control rod $\mathrm{H}-1$ from Position 48 (fully withdrawn) to Position 36. The $N S O$ and two individuals in training to become nuclear engineers were in the control room when Mr. Miller, the QNE on duty and an unlicensed individual, recognized the NSO's error. Mr. Miller informed the Nso of the error, the Nso continued to move control rods at Mr. Miller's direction, without the knowledge or approval of the Station Control Room Engineer (SCRE), and then Mr. Miller informed the SCRE of the event. Later the SCRE spoke with Mr. Miller, the NSo and the two nuclear engineers in training and they all agreed that they would not discuss the incident with anyone else. As a result, neither the mispositioned rod nor the subsequent deviation from the planned control rod pattern were documented in the control room log, Mr. Miller falsified a Form 14-14C plant record, and CECO management was not informed of the incident.

Dresden Technical specification 6.2.A.1 stated that applicable procedures recomended in Appendix $A$ of Regulatory Guide 1.33, Revision 2 dated February 1978, shall be established, implemented, and maintained. Regulatory Guide 1.33, Appendix A.1.c, included adminlstrative procedures, general plant 
operating procedures, and procedures for startup, operation, and shutdown of safety related systems.

Dresden Operating Abnormal Procedure (DOA) 300-12, "Mispositioned Control Rod", Revision 2, November 1991, Section C.2, required, in part, that if a control rod is moved more than one even notch from its in-sequence position, then all control rod movement must be discontinued. Section D.2.a. (1) required, in part, that if a single control rod is inserted more than one even notch from its in-sequence position and reactor power is greater than 20\%, and if the mispositioning occurred within the last 10 minutes, then the mispositioned control rod must be continuously inserted to Position 00. Section D.6 required that an upper mangement representative will conduct an evaluation into the cause of the mispositioning and implemont immediate corrective actions prior to the resumption of routine control rod movements.

These procedures were not followed. Specifically, the Nso failed to insert the mispositioned control rod to Position 00, and continued to move control rods solely at the direction of Mr. Miller and without the performance of an evaluation and corrective actions by an upper management representative.

Dresden Administrative Procedure (DAP) 14-14, "Control Rod Sequences," Revision 0 , dated November 1991, section F.1.e, required that Form 14-14C, "Special Instructione", must provide 
instructions which should be clearly stated and strictly adhered to and reguired that the instructions be approved by the QNE (in this case, Mr. Miller) and an operations shift supervisor. However, on September 18, 1992, following the mispositioning of control rod H-1, control rod arrays $8 D 2$ and 5 were moved at Mr. Miller's direction and without the completion of a special Instruction Form 14-14C clearly stating the sequence, and without prior approval of Mr. Miller's instructions by an operations shift supervisor. By directing the continued movement of control rods without the approval of a licensed operator, Mr. Miller, who is not a licensed operator, violated 10 CFR 55.3. Furthermore, after these rods had been moved, Mr. Miller knowingly completed a Form 14-14C to indicate a different sequence of control rod movements than that which actually occurred. The effect of this inaccurate Form 14-14C was to conceal the mispositioning of control rod $\mathrm{H}-1$ and the subsequent movement of control rods in violation of plant procedures.

Based on the MRC Office of Investigations (OI) investigation of this matter (OI Roport No. 3-92-055R), I conclude that Mr. Miller, along with certain other CECo employees, deliberately attempted to conceal the mispositioned control rod event by talling to document the incident as required by plant procedures. By falsifying the Form 14-14C, Mr. Miller deliberately put CECo 
in violation of Dresden Technical specification 6.2.A.1, DAP 1414, Section F.1.e., and 10 CFR 50.9, "Completeness and Accuracy of Information".

Based on the above, Mr. Miller, an employee of CECo at the time of the event, engaged in deliberate misconduct which caused CECo. to be in violation of its license conditions and 10 CFR 50.9, and which constitutes a violation of 10 CFR 50.5 and 10 CFR 55.3.

The NRC must be able to rely on its licensees and their employees to comply with NRC requirements, including the requirement to maintain records that are complete and accurate in all material respects. Mr. Miller's action in causing CECo to violate its license conditions and 10 CFR 50.9 have raised serious doubt as to whether he can be relied upon to comply with NRC requirements, including the requirements to maintain complete and accurate records. Mr. Miller's deliberate misconduct that caused CECo to violate comiseion requirements cannot and will not be tolerated.

Consequentiy, I lack the requisite reasonable assurance that licensed activities can be conducted in compliance with the Commission's requirements and that the health and safety of the public will be protected, if Mr. Miller were permitted at this time to be engaged in the performance of NRC-licensed and 
regulated activities. Therefore, the public health, safety and interest require that Mr. Miller be prohibited from being involved in any NRC-licensed activities for three years from the date of this order. In addition, for the same period, Mr. Miller is required to give notice of this order to any prospective employer engaged in MRC-licensed activities as described in Section IV, Paragraph B, below, from whom he seeks employment in non-licensed activities to ensure that such employer is aware of Mr. Miller's previous history. For five years from the date of this Order, Mr. Miller is also required to notify the NRC of his employment by any person engaged in NRC-licensed activities, as described in section IV, Paragraph B, below, so that appropriate inspections can be performed. Furthermore, pursuant to $10 \mathrm{CFR}$ 2.202, I find that the significance of the conduct described above is such that the public health, safety and interest require that this order be imediately effective.

Accordingly, pursuant to sections 103, 161b, 161i, 1610, 182 and 186 of the Atonic Energy Act of 1954, as amended, and the Comission's regulations in $10 \mathrm{CFR} 2.202$ and $10 \mathrm{CFR} 50.5$, IT IS HEREBY ORDERED, EFFECTIVE IMCEDIATELY, THAT: 
A. Mr. Miller is prohibited for three years from the date of this order from engaging in activities licensed by the NRC.

B. Should Mr. Miller seek employment in non-licensed activities with any person engaged in NRC-licensed activities for three years from the date of this order. Mr. Miller shall provide a copy of this order to such. person at the time Mr. Miller is soliciting or negotiating employment so that the person is aware of the order prior to making an employment decision. For the purposes of this order, licensed activities include the activities of: (1) an NRC Iicensee; (2) an Agreement state licensee conducting NRC-licensed activities purauant to 10 CFR 150.20 ; and (3) an Agreement state licensee involved in the distribution of products that are subject to NRC jurisdiction.

c. For three years from the date of this order, Mr. Miller ahall provide notice to the Director, office of Enforcenent, U. S. Nuclear Regulatory Combission, Washington, DC 20555, of the name, address, and telephone number of the employer, within 72 hours of his acceptance of an employment offer involving nonlicensed activities for an employer engaged in melicensed activities described in paragraph IV.B, above. 
D. After the three year prohibition has expired as described in Paragraphs IV.A and B above, Mr. Miller shall provide notice to the Director, office of Enforcement, for acceptance of any employment in NRClicensed activity for an additional two year period.

The Director, office of Enforcement may, in writing, relax or rescind any of the above conditions upon demonstration by $\mathrm{kr}$. Miller of good cause.

v

In accordance with $10 \mathrm{CFR} 2.202$, Mr. Miller must, and any other person adversely affected by this order may, submit an answer to this order, and may request a hearing within 30 days of the date of this order. The answer may consent to this order. Unless the answer consents to this order, the answer shall, in writing and under oath or affirmation, specifically admit or deny each allegation or charge made in this order and shall set forth the matters of sact and law on which Mr. Miller or other person adversely affected relies and the reasons as to why the order should not have been lesued. Any answer or requeat for a hearing shall be submitted to the Secretary, U. S. Nuclear Regulatory Comission, ATTN: Chief, Docketing and Service section, Washington, DC 20555. Coples also shall be sent to the Director, Office of Enforcement, U. S. Nuclear Regulatory 
Commission, Washington, DC 20555; to the Assistant General

Counsel for Hearings and Enforcement at the same address; to the Regional Administrator, Region III, U. S. Nuclear Regulatory Commission, 801 Warrenville Road, Lisle, Illinois 60532-4351; and to Mr. Miller, if the answer or hearing request is by a person other than Mr. Miller. If a person other than Mr. Miller requests a hearing, that person shall set forth with particularity the manner in which his interest is adversely affected by this order and shall address the criteria set forth in 10 CFR $2.714(d)$.

If a hearing is requested by Mr. Miller or a person whose interest is adversely affected, the comiseion will issue an order designating the time and place of any hearing. If a hearing is held, the lssue to be considered at such hearing shall be whether this order should be sustained.

Pursuant to $10 \mathrm{CFR} 2.202$ (c)(2)(1), Mr. Miller, or any person adversely affected by this order, may in addition to demanding a hearing, at the tim that answer is filed or sooner, move the presiding officer to set aside the immediate effectiveness of the order on the ground that the order, including the need for immediate effectiveness, is not based on adequate evidence but on mere suspicion, unfounded allegations, or error. 
In the absence of any request for a hearing, the provisions specified in section IV above shall be final 20 days from the date of this order without further order or proceedings. AN ANSWER OR A REQUEST FOR A HEARING SHALL NOT STAY THE IMOYEDIATE EFFECTIVENESS OF THIS ORDER.

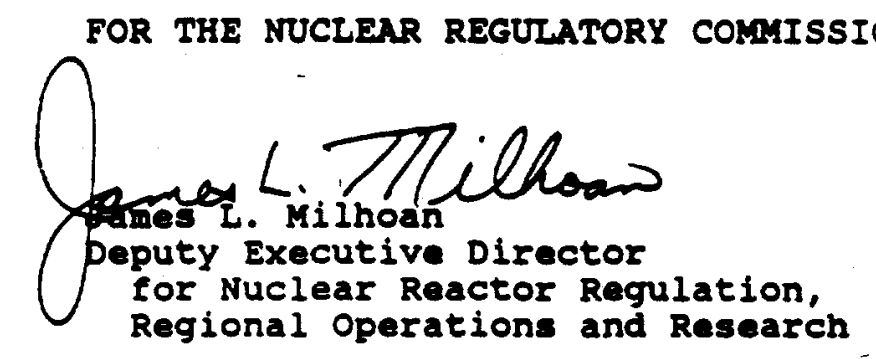

Dated at Rockville, Maryland

this 2/st'day of April 1994 


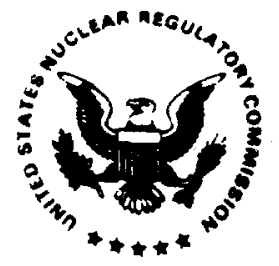

\section{UNITED STATES \\ NUCLEAR REgULATORY COMMISSION \\ WASHiNGTON. D.C. 20686-0001}

NUG 26 isSs

IA $94-018$

Richard E. Odegard

(HOME ADORESS DELETED

UNDER 10 (FR 2.790)

SUBJECT: ORDER PROHIBITING INVOLVEMENT IN NRC-LICENSED ACTIVITIES (EFFECTIVE IMMEDIATELY)

The enclosed Order is being issued because of your violations of. 10 CFR 30.10 of the Commission's regulations as described in the Order.

Based on an investigation conducted by the Nuclear Regulatory Commission's Office of Investigation, the NRC Staff has determined that you deliberately conspired with other AMSPEC officials to deceive the Commission and provided false testimony, under oath, to NRC officials. In addition, you deliberately failed to train and certify employees in radiation safety as required by the AMSPEC license conditions. A copy of the synopsis of the investigation is enclosed.

Failure to comply with the provisions of this Order may result in further civil or criminal sanctions.

Questions concerning this Order should be addressed to Mr. James Lieberman, Director, Office of Enforcement, who can be reached at (301) 504-2741.

In accordance with 10 CFR 2.790 of the NRC's "Rules of Practice," a copy of this letter and the enclosures will be placed in the NRC's Public Document Room.

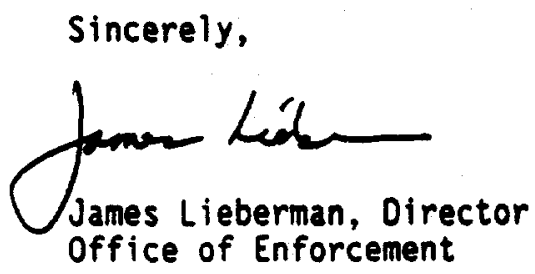

Enclosures:

1. Order

2. OI Synopsis 
UNITED STATES

NUCLEAR REGULATORY COMMISSION

In the Matter of

Richard E. Odegard

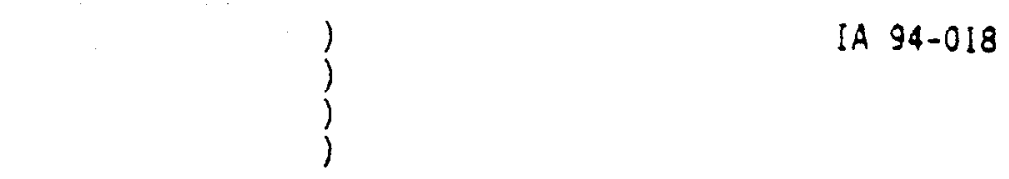

ORDER PROHIBITING INVOLVEMENT IN

NRC-LICENSED ACTIVITIES

(EFFECTIVE IMMEDIATELY)

I

Richard E. Odegard has been employed as a radiographer in the field of industrial radiography since approximately 1978. On approximately June 20 , 1989, Mr. Odegard was hired by the American Inspection Company, Inc. (AMSPEC). AMSPEC held Materials License No. 12-24801-01 issued by the Nuclear Regulatory Commission (NRC or Commission) pursuant to 10 CFR Parts 30 and 34 . This license authorized the conduct of industrial radiography activities in accordance with specified conditions. On April 30, 1992, the license was suspended as a result of significant safety violations and related safety concerns. Mr. Odegard was a Vice-President of AMSPEC at the time of license suspension.

II

Between August 22, 1991 and November 12, 1992, the NRC Office of Investigations conducted an investigation of licensed activities at AMSPEC. During the course of this investigation, the AMSPEC license was suspended when a significant number of safety violations were identified. In addition, the investigation revealed that Mr. Odegard, in his capacity as a Vice-President and Area Manager for AMSPEC, conspired with other AMSPEC officials to deceive 
the Commission regarding training of employees and, in addition, deliberately provided false sworn testimony to NRC officials.

AMSPEC submitted a Radiation Safety Manual as a part of its license application dated September 20, 1986. A part of this manual refers to employee training to satisfy the requirements of Appendix $A$ of 10 CFR Part 34 . This manual was incorporated as a part of License Condition 17 of the AMSPEC license. 10 CFR 30.9 (a) requires, in part, that information provided to the Commission by a licensee, and information required by the Commission's regulations to be maintained by the licensee, shall be complete and accurate in all material respects. 10 CFR 30.10 (a) requires, in part, that any licensee or any employee of a licensee may not: (1) engage in deliberate misconduct that causes a licensee to be in violation of any rule, regulation, or limitation of any license, issued by the Commission, or (2) deliberately submit to the NRC information that the person submitting the information knows to be incomplete or inaccurate in some respect material to the NRC.

Between late 1989 and March 1, 1992, Mr. Odegard deliberately created false documents concerning the training of AMSPEC employees (documents that were required by the Comission's regulations to be maintained by AMSPEC), causing a violation of 10 CFR 30.9 by AMSPEC. During 1990 and 1991, Mr. Odegard deliberately provided unauthorized and improper aid to AMSPEC employees taking radiation safety examinations, a violation of License Condition 17 . Between late 1989 and the end of 1991, Mr. Odegard deliberately falsified records of quarterly personnel radiation safety audits, causing violations of 10 CFR 30.9 and 34.11(d). On Apri1 13, 1993, Mr. Odegard deliberately provided false 
testimony under oath during the NRC investigation, a violation of 10 CFR 30.10 .

On January 29, 1993, Mr. Odegard pled guilty to one felony count involving deliberate violations of the Atomic Energy Act based on his violations of these requirements.

$$
\text { III } 1
$$

Based on the above, Mr. Odegard engaged in deliberate misconduct which caused AMSPEC to be in violation of the training requirements of License Condition 17 and NRC regulations, including 10 CFR 30.9 and $34.11(d)$. The NRC must be able to rely on licensees and their employees to comply with NRC requirements, including the requirements to train and certify employees in radiation safety and procedures and the requirenent to provide information that is complete and accurate in all material respects. Mr. Odegard's actions in deliberately causing AMSPEC to be in violation of NRC requirements regarding training and completeness and accuracy of information and his deliberate misrepresentations to NRC officials in violation of 10 CFR 30:10 have raised serious doubt as to whether he can be relied an to comply with NRC requirenents, specifically the requirement to provide complete and accurate information to the NRC. Mr. Odegard's deliberate misconduct, including his false statement to Commission officials, cannot and will not be tolerated.

Consequently, I lack the requisite reasonable assurance that licensed activities can be conducted in compliance with the Commission's requirenents and that the health and safoty of the public will be protected if Mr. Odegard 
were permitted at this time to supervise or perform licensed activities in any area where the NRC maintains jurisdiction. Therefore, the public health, safety and interest require that Mr. Odegard be prohibited from engaging in NRC licensed activities (including supervising, training or auditing) for either an NRC licensee or an Agreement State licensee performing licensed activities in areas of NRC jurisdiction in accordance with 10 CFR 150.20 for a period of five years from the date of this Order. In addition, for a period of five years commencing after completion of the five-year period of prohibition, Mr. Odegard is required to notify the NRC of his employment by any person or entity engaged in NRC-licensed activities, to ensure that the NRC can monitor the status of Mr. Odegard's compliance with the Commission's requirements and his understanding of his commitment to compliance. Furthermore, pursuant to 10 CFR 2.202, I find that the significance of the conduct described above is such that the public health, safety and interest require that this order be effective immediately.

IV

Accordingly, pursuant to sections $81,161 \mathrm{~b}, 161 \mathrm{i}, 182$ and 186 of the Atomic Energy Act of 1954, as amended, and the Commission's regulations in 10 CFR 2.202, 10 CFR 30.10, and 10 CFR 150.20, IT IS HEREBY ORDERED, EFFECTIVE IMMEDIATELY, THAT:

1. Richard E. Odegard is prohibited for five years from the date of this Order from engaging in NRC-licensed activities. NRC-licensed activities are those activities which are conducted pursuant to a specific or general license issued by the NRC, including, but not linited to, those 
activities of Agreement State licensees conducted pursuant to the authority granted by 10 CFR 150.20. During this time period, Mr. Odegard must also provide a copy of this Order to prospective employers who engage in NRC-licensed activities, at the time he accepts employment.

2. For a period of five years after the five-year period of prohibition has expired, Richard E. Odegard shall, within 20 days of his acceptance of an employment offer involving NRC-licensed activities or his becoming involved in MRC-licensed activities, as defined in Paragraph IV.1 above, provide notice to the Director, Office of Enforcement, U. S. Nuclear, Regulatory Commission, Washington, D.C. 20555, of the name, address, and telephone number of the employer or the entity where he is, or will be, involved in the MRC-11censed activities. In the first notification Mr. Odegard shall include a statement of his commitment to compliance with regulatory requirements and the basis why the Commission should have confidence that he will now comply with applicable NRC requirements.

The Dtrector, Office of Enforcement, may in writing, relax or rescind any of the above conditions upon demonstration by Mr. Odegard of good cause.

v

In accordance with 10 CFR 2.202, Richard E. Odegard must, and any other person adversely affected by this Order may, submit an answer to this Order, and may request a hearing on this Order, within 20 days of the date of this Order. 
The answer may consent to this Order. Unless the answer consents to this Order, the answer shall, in writing and under oath or affirmation, specifically admit or deny each allegation or charge made in this order and shall set forth the matters of fact and law on which Richard E. Odegard or any other person adversely affected relies and the reasons as to why the Order should not have been issued. Any answer or request for a hearing shall be submitted to the Secretary, U. S. Nuclear Regulatory Commission, ATTN: Chief, Docketing and Service Section, Washington, D.C. 20555. Copies also shall be sent to the Director, Office of Enforcement, U. S. Nuclear Regulatory Commission, Washington, D.C. 20555, to the Assistant General Counsel for Hearings and Enforcement at the same address, to the Regional Administrator, NRC Region II, 101 Marietta Street, N. W., Suite 2900, Atlanta, Georgia 30323, and to Richard E. Odegard if the answer or hearing request is by a person other than Richard E. Odegard. If a person other than Richard $E$. Odegard requests a hearing, that person shall set forth with particularity the manner in which his or her interest is adversely affected by this Order and shall address the criteria set forth in 10 CFR 2.714(d).

If a hearing is requested by Richard E. Odegard or another person whose interest is adversely affected, the Comission will issue an Order designating the time and place of any hearing. If a hearing is held, the issue to be considered at such hearing shall be whether this order should be sustained.

Pursuant to 10 CFR $2.202(C)(2)(i)$, Richard E. Odegard or any other person adversely affected by this Order, ayy, in addition to demanding a hearing, at the time the answer is filed or sooner, move the presiding officer to set aside the immediate effectiveness of the Order on the ground that the Order, 
7

including the need for immediate effectiveness, is not based on adequate evidence but on mere suspicion, unfounded allegations, or error.

In the absence of any request for hearing, the provisions specified in Section IV above shall be final 20 days from the date of this Order without further order or processing. AN ANSWER OR A REQUEST FOR HEARING SHALL NOT STAY THE IMUEDIATE EFFECTIVENESS OF THIS ORDER.

FOR THE NUCLEAR REGULATORY COMISSION

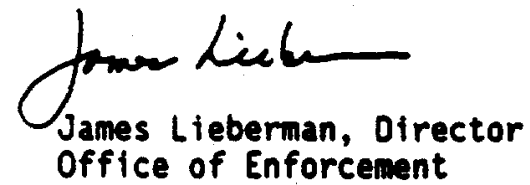

Dated at Rockville, Maryland this X6h day of August 1994 
On August 22, 1991, the Regional Administrator, U.S. Nuclear Regulatory Commission (NRC), Region II, requested an investigation to determine whether officials, managers, and/or employees of The American Inspection Company, Inc. (AMSPEC), the ijcensee, had intentionally violated regulatory and license condition requirements set forth in 10 CFR Parts 20,30 , and 34 and the NRC Iicense of January 15, 1987, respectively. According to reported allegations, licensee management officials had permitted unqualified technicians to perform radiography operations at the Hess Oll Virgin Islands Company (HOVIC) facility, st. Croix, U.S. Virgin Islands, which had contracted with AMSPEC for nondestructive examination services.

Additionally, licensee officials allegedly: (1) discriminated (involuntary termination) against technicians for reporting radiation health and safety concerns, (2) falsifled radiation safety training documents, (3) provided false and misleading information to the NRC, and (4) used source material in a manner not authorized by the license (irradiation of mice).

The office of Investigations (OI) reviewed the circumstances of the alleged regulatory and license condition violations during which other improprieties by the licensee were identified. The investigation by oI did not substantiate that licensee management officials had terminated radiography technicians for reporting radiation health and safety concerns. It was concluded, however, that these licensee officials at the HovIC facility appeared insensitive to employee concerns of all topice, including radiation safety, and they were parceived by technicians as acting with apparent disregard concerning this issue. The investigation further determined that licensee officials deliberately provided false and misleading radiation safetyrelated information to ARC representatives which was pertinent to the regulatory process. The investigation substantiated that the licensee, through actiona of some radiation protection officers (RPOS), deliberately faleifled radiation safety training records, inserted false records in technician flles to give the impression required training wa accomplished, and they aiso conspired to conceal these training defletencies and improprieties from the NRC. The investigation surfaced and substantiated the allegation that licensee offlelals and RPOs deliberately falsified required personnel radiation safety audits and accompanying reports and they also created audit reports to make complete the radiation safety files of some techniciane.

The investigation also disclosed and conelrmed numerous instances of radiographers' assistants pertorming radlography without supervision and the delibarate falalifieation of source utilization logs to give the appearance that required supervision was present, ell vith the apparent knowledge and concurrence of licensee manageant offlcials. It was also determined during the investigation that licensee tralning officlals (RPOs) frequenty

Case No. 2-91-010R 
failed to provide the Operation and Emergency Procedures (OSEP) Manual to new employees prior to source utilization. The investigation also determined that some licensee RPOs were not trained, examined, and certified according to Radiation Safety Program requifements and AMSPEC officials, including the radiation safety offlcer (RSO) and several RPOs, were aware of some of these violations and failed to correct them. Further, on at least one occasion, the RSO and an RPO conspired to concoct a plausible explanation for the NRC as to why RPO examination/certification requirements were violated.

The investigation substantiated the allegation that radioactive source material was utilized improperly when an AMSPEC night shift supervisor, in the presence of technicians, radiographed a mouse during two to three consecutive source exposures at the HOVIC facility. The OI investigation, and a previous NRC inspection at the St. Croix location, also revealed instances in which AMSPEC technicians lailed to observe required surveying and posting activities during radiography operations, actions which demonstrated either an apparent disregard for regulations and/or radiation safety training deficiencies.: Finally, the investigation disclosed that the RSO and other licensee management officials deliberately falled to perform required radiation safety review, evaludtion, and oversight functions and responsibilities during the past 3 years. 


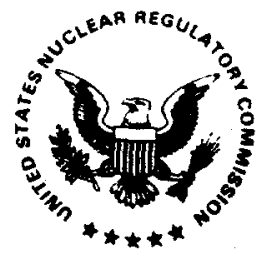

\section{UNITED STATES \\ NUCLEAR REGULATORY COMMISSION \\ WASHINGTON, D.C. 20585-0001}

July 16,1996

\section{IA $96-043$}

Mr. Jesus Osorio

[HOME ADDRESS DELETED

UNDER 2.790]

\section{SUBJECT: ORDER PROHIBITING INVOLVEMENT IN NRC-LICENSED ACTIVITIES}

Dear Mr. Osorio:

The enclosed Order Prohibiting Involvement in NRC-Licensed Activities is being issued because of your deliberate misconduct, in violation of 10 CFR 30.10 of the Commission's regulations, as described in the Order. The Order becomes effective in 20 days unless a hearing is requested within this time.

Pursuant to Section 223 of the Atomic Energy Act of 1954, as amended, any person who willfully violates, attempts to violate, or conspires to violate, any provision of this order, once it becomes effective, shall be subject to criminal prosecution as set forth in that section. Failure to comply with the provisions of this Order may also result in civil sanctions.

Questions concerning this Order should be addressed to Mr. James Lieberman, Director, Office of Enforcement, who may be reached at (301) 415-2741.

In accordance with 10 CFR 2.790 of the NRC's "Rules of Practice," a copy of this letter and the enclosure will be place in the NRC's Public Document Room.

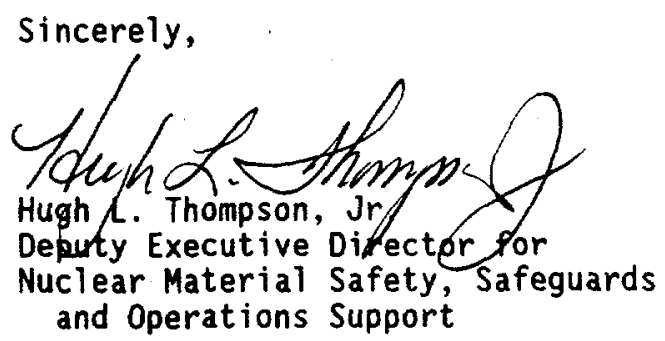

Enclosure: Order Prohibiting Involvement

in NRC-Licensed Activities

cc: Commonwealth of Puerto Rico 
UNITED STATES

NUCLEAR REGULATORY COMMISSION

In the Matter of

Jesus N. Osorio

[HOME ADDRESS DELETED

UNDER 10 CFR 2.790]

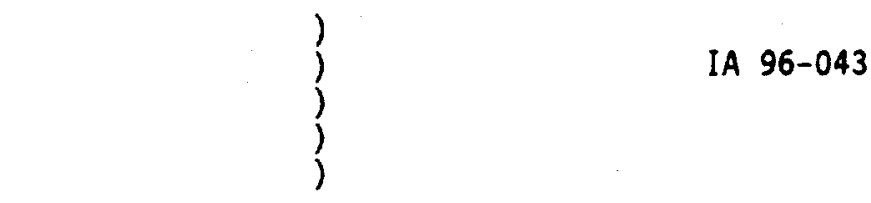

ORDER PROHIBITING INVOLVEMENT IN NRC-LICENSED ACTIVITIES

I

Jesus N. Osorio was employed as the Radiation Safety Officer (RSO) of NDT Services, Inc. (NDTS or Licensee) in Caguas, Puerto Rico, in 1993. NDTS holds License No. 52-19438-01, issued to the Licensee in 1987 and last amended by the Nuclear Regulatory Commission (NRC or Commission) pursuant to 10 CFR Part 30, on March 9, 1995. The license authorizes industrial gamma ray radiography in accordance with the conditions specified therein. Mr. Osorio was identified in consecutive amendments to NRC License No. 52-19438-01, dated January 12, 1992 and October 26, 1993, and in other licensing correspondence, as the RSO for NDTS.

On December 16-17, 1993, a special inspection of NDTS' activities was conducted at the Licensee's facility in Caguas, Puerto Rico, in response to notifications received in the NRC Region II office that on September 4, 1993, two contract radiographers' employed by NOTS had been unable to return a radiography source to its shielded position following radiographic operations,

1

The radiographers involyed in the event were contracted by wors from Mational Inspection and Consultants (NIC), an Agreement State licensee in Florida. White no written contract was established to outline the scope and conditions of work, based on the information available, the NRC concluded that the work performed on Septenber 4, 1993, was performed under the provisions of the Nots license. 
which resulted in the evacuation of the Sun 0 il Company refinery located in Yabucoa, Puerto Rico, for several hours. Based on the results of the inspection, an investigation was initiated by the NRC Office of Investigations (OI) on December 30, 1993.

On December 21, 1995, OI completed its investigation and concluded, in part, that: (1) NDTS, with the knowledge and approval of the former RSO and former President, deliberately utilized radiographers untrained in NOTS operating and emergency procedures; and (2) NOTS, through the actions of the former RSO, provided the NRC with documentation that falsely certified the radiographers' training.

During an August 31, 1995 interview with 01, Mr. Osorio stated that he was aware that the radiographers needed training and that they were required to pass a proficiency test prior to working at the Sun 0 il Company refinery. Mr. Osorio added that, prior to hiring the radiographers, he informed NDTS' former President that the radiographers would have to be trained and tested on NDTS equipment. Nonetheless, Mr. Osorio did not train the radiographers because they left for their accommodations and he was tired and went home, al though he knew that they would work their shift without the required training. As to the false training documentation, Mr. Osorio stated that he knew he signed false documentation and that such falsification constituted a violation of NRC regulations, but he signed the documentation because he "needed to have something." 
Based on the OI conclusions, the NRC further concluded that during the December 16-17, 1993 inspection, the former RSO orally represented to an NRC inspector that he demonstrated the safe use of the NDTS radiography equipment prior to allowing two contract radiographers to operate the equipment on September 3, 1993, when he knew that he had not conducted such a demonstration.

On February 15, 1996, Mr. Osorio was contacted by telephone and initially informed of the inspection and investigation results and was provided the opportunity to participate in a predecisional enforcement conference. During this telephone conversation, Mr. Osorio declined to attend this conference. By letter dated February 20, 1996, Mr. Osorio was transmitted the Inspection Report and the synopsis of the $O I$ investigation and again offered the opportunity to attend a conference. To date, Mr. Osorio has not responded to the February 20, 1996 letter. No conference has been conducted with him; however, on May 16, 1996, a teleconference was conducted with Mr. Osorio to further discuss this case. Additional1y, on February 29 and March 4, 1996, predecisional enforcement conferences were conducted with one of the contract radiographers, and NDTS, respectively.

Based on the information gathered during the inspection, investigation, predecisional enforcement conferences, and subsequent interviews in this case, the NRC has determined that: (1) Mr. Osorio deliberately permitted unqualified radiographers to perform radiography for NDTS on September 4 , 1993 , in that he knew the radiographers had not been trained in NDTS procedures or equipment; (2) on December 16, 1993, Mr. Osorio provided an NRC 
$-4-$

inspector with written certification of the qualifications of the two contract radiographers, dated September 3, 1993, which falsely indicated that the radiographers had been qualified based on records obtained from their principal employer and by the experience demonstrated by the contract radiographers to him; and (3) on December 16, 1993, Mr. Osorio provided false oral statements to an NRC inspector indicating that he had demonstrated the safe use of the NOTS radiography equipment to the radiographers on September 3, 1993, when, in fact, he had not conducted such a demonstration.

Based on the above, the staff concludes that Mr. Osorio engaged in deliberate misconduct, a violation of 10 CFR 30.10 , which caused the Licensee to be in violation of 10 CFR 34.31 (a) by deliberately failing to utilize trained and qualified individuals during the conduct of radiographic operations at the Sun 0il Company refinery on September 4, 1993. Mr. Osorio also violated 10 CFR 30.10 (a) (2), and caused the Licensee to be in violation of 10 CFR 30.9 , by deliberately providing materially inaccurate and incomplete information to the NRC. As the former RSO of NDTS, Mr. Osorio was responsible to assure that NDTS conducted activities in accordance with NRC requirements and the NDTS radiation safety program. The NRC must be able to rely on the Licensee, its officials and employees to comply with NRC requirements, including the requirements to train radiographers in accordance with NRC regulations and to provide complete and accurate information to the NRC. Mr. Osorio's deliberate misconduct in causing the Licensee to violate 10 CFR 34.31(a), and his deliberate submission to the NRC materially inaccurate and incomplete 
information, are violations of 10 CFR 30.10 and have raised serious doubt as to whether he can be relied upon to comply with NRC requirements.

Consequently, I lack the requisite reasonable assurance that licensed activities can be conducted in compliance with the Commission's requirements and that the health and safety of the public will be protected if Mr. Osorio were permitted at this time to be involved in NRC-licensed activities. Therefore, the public health, safety and interest require that $\mathrm{Mr}$. Osorio be prohibited from any involvement in NRC-licensed activities for a period of five years, and, if he is currently involved with another licensee in NRC-licensed activities, he must, following the effective date of this Order, cease such activities, and inform the NRC of the name, address and telephone number of the employer, and provide a copy of this order to the employer. Additionally, Mr. Osorio is required to notify the NRC of his first employment involving NRC-licensed activities within a period of five years following the five-year prohibition period.

Accordingiy, pursuant to sections $81,161 \mathrm{~b}, 161 \mathrm{i}, 182$ and 186 of the Atomic Energy Act of 1954, as amended, and the Commission's regulations in 10 CFR 2.202, and 10 CFR 30.10 , IT IS HEREBY ORDERED THAT:

A. For a period of five years from the effective date of this Order, Jesus N. Osorio is prohibited from engaging in, or exercising control over individuals engaged in NRC-licensed activities. NRC-licensed activities 
are those activities which are conducted pursuant to a specific or general license issued by the NRC, including, but not limited to, those activities of Agreement State licensees conducted pursuant to the authority granted by 10 CFR 150.20 . This prohibition includes, but is not limited to: (1) using licensed materials or conducting licensed activities in any capacity within the jurisdiction of the NRC; and (2) supervising, directing, or serving as Radiation Safety Officer for any licensed activities conducted within the jurisdiction of the NRC.

B. At least five days prior to the first time that Jesus $N$. Osorio engages in, or exercises control over, NRC-licensed activities within a period of five years following the five-year prohibition in Section IV.A above, a, he shall notify the Director, Office of Enforcement, U. S. Nuclear Regulatory Commission, Washington, D.C. 20555, of the name, address, and telephone number of the NRC or Agreement State licensee and the location where the licensed activities will be performed. The notice shall be accompanied by a statenent, under oath or affirmation, that Jesus N. Osorio understands NRC requirements, that is committed to compliance with NRC requirements, and that provides a basis as to why the Commission should have confidence that he will now comply with applicable NRC requirements.

The Director, Office of Enforcement, may, in writing, relax or rescind any of the above conditions upon demonstration by Mr. Osorio of good cause. 
In accordance with 10 CFR 2.202, Jesus $N$. Osorio must, and any other person adversely affected by this Order may, submit an answer to this Order, and may request a hearing on this Order, within 20 days of the date of this Order. Where good cause is shown, consideration will be given to extending the time to request a hearing. A request for extension of time must be made in writing to the Director, Office of Enforcement, U.S. Nuclear Regulatory Commission Washington, D.C. 20555, and include a statement of good cause for the extension. The answer may consent to this Order. Unless the answer consents to this Order, the answer shall, in writing and under oath or affirmation, specifically admit or deny each allegation or charge made in this Order and shall set forth the matters of fact and law on which Mr. Osorio or other person adversely affected relies and the reasons as to why the order should not have been issued. Any answer or request for a hearing shall be submitted to the Secretary, U.S. Nuclear Regulatory Commission, Attn: Chief, Docketing and Service Section, Washington, OC 20555. Copies also shall be sent to the Director, Office of Enforcement, U.S. Nuclear Regulatory Commission, Washington, DC 20555, to the Assistant General Counsel for Hearings and Enforcement at the same address, to the Regional Administrator, NRC Region II, Suite 2900, 101 Marietta Street, Atlanta, GA 30323, and to Jesus N. Osorio, if the answer or hearing request is by a person other than Jesus $N$. Osorio. If a person other than Jesus N. Osorio requests a hearing, that person shall set forth with particularity the manner in which his or her interest is adversely affected by this Order and shall address the criteria set forth in 10 CFR $2.714(d)$. 
If a hearing is requested by Jesus $N$. Osorio, or another person whose interest is adversely affected, the Commission will issue an Order designating the time and place of any hearing. If a hearing is held, the issue to be considered at such hearing shall be whether this Order should be sustained.

In the absence of any request for hearing, or written approval of an extension of time in which to request a hearing, the provisions specified in Section IV above shall be final 20 days from the date of this Order without further order or proceedings. If an extension of time for requesting a hearing has been approved, the provisions specified in Section IV shall be final when the extension expires if a hearing request has not been received.

FOR THE NUCLEAR REGULATORY COMMISSION

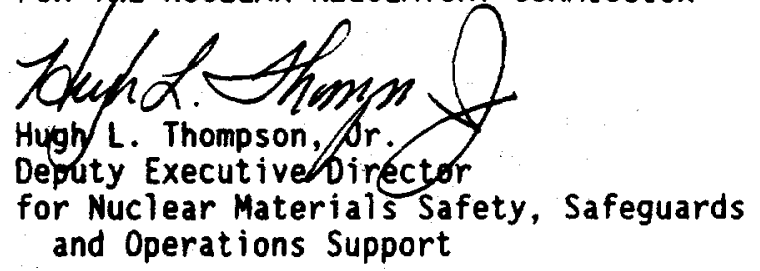

Dated at Rockville, Maryland

this 16tdday of July 1996 


\section{UNITED STATES \\ NUCLEAR REGULATORY COMMISSION \\ WASHINGTON. O.C. 206000001}

MAP 10 1994

IA $94-001$

Mr. Hartsell S. Phillips

(Address deleted)

Dear sir:

SUBJECT: ORDER PROHIBITING INVOLVEMENT IN NRC-LICENSED ACTIVITIES (EFFECTIVE IMMEDIATELY)

The enclosed order is being issued because of your violations of 10 CFR Part 30 of the Commission's regulations as described in the order.

Failure to comply with the provisions of this order may result in civil or criminal sanctions.

Questions concerning this order should be addressed to Mr. James Lieberman, Director, office of Enforcement, who may be reached at (301) 504-2741.

In accordance with 10 CFR 2.790 of the NRC's "Rules of Practice," a copy of this letter and the enclosure will be placed in the NRC's Public Document Room.

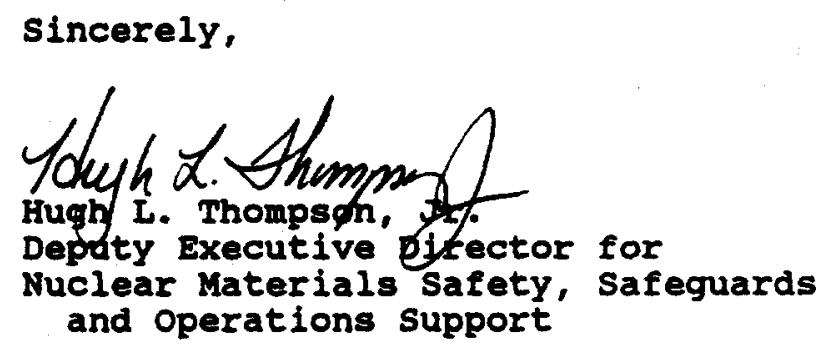

Enclosure: As stated

cc: Logan General Hospital

state of West virginia 
UNITED STATES

NUCLEAR REGULATORY COMMISSION

In the Matter of

Hartsell s. Phillips

)

$\{$ IA $94-001$

ORDER PROHIBITING INVOLVEMENT

IN NRC-LICENSED ACTIVITIES

(EFFECTIVE IMMEDIATELY)

Hartsell S. Phillips is employed by Logan General Hospital, Logan, West Virginia. Logan General hospital (Licensee) holds License No. 47-19919-01 issued by the Nuclear Regulatory Commission (NRC or Commission) pursuant to 10 CFR parts 30 and 35. The license authorizes possession and use of byproduct material in accordance with the conditions specified therein. Mr. Phillips has been employed by the Licensee since approximately June 1991 as the Chief Technologist, Radiation Safety officer (RSO), and Chairman of Radiation Safety Committee with responsibilities involving compliance with NRC requirements for radiation protection. Mr. Phillips was removed as Chairman of the Radiation Safety Committee on January 1, 1994, and removed as RSO on February 18, 1994. On February 22, 1994, the Licensee informed the NRC that it had suspended, subject to termination, Mr. Phillips on February 18, 1994, based on information the Licensee had received through interviews with its staff and other information developed by the Licensee. 
On December 7-8, 1993, an NRC inspection was conducted at the Licensee's facility in Logan, West Virginia. As a result of information developed during that inspection, an investigation by the office of Investigations (OI) was initiated in January 1994. Although this investigation is continuing, or interviews of Licensee personnel and review of documents provided by or reveal that nuclear medicine technologists under Mr. Phillips' supervision and at his direction, and $\mathrm{Kr}$. Phillips himself, deliberately increased radiopharmaceutical dosages administered to patlents above the dosages prescribed by the authorized user and set forth in the Licensee's procedures manual, and falsified the dosage records of those patients by making them appear as if the prescribed dosages had been administered. The OI interviews indicate that this practice of increasing dosages and of falsifying records continued for an extended period of time. The exact number of patients affected is not clear, but involved numerous administrations.

In addition, Mr. Phillips falsified records and directed nuclear medicine technologists under his supervision to falsify records relating to: training of nuclear medicine technologists, required by 10 CFR 19.12; daily dose calibrator constancy checks, required by 10 CFR 35.50 (b)(1); daily and weekly surveys in nuclear medicine areas, required by 10 CFR $35.70(a),(b)$, and (e); and 
3

surveys related to the receipt and shipment of licensed material, required by 10 CFR 20.205 (d) and Iicense Condition 16. Specifically, these records indicated that the training, checks and surveys had been performed when in fact they had not been performed. The records falsification occurred for an extended period of time and may have been as long as 15 months during 1992 and 1993, and involved the falsification of records for surveys and training in nuclear medicine required during this pertod of time. The investigation also revealed that Mr. Phillips specifically instructed one nuclear medicine technologist to deny having falsified records and advised others to be untrutheul when questioned by NRC inspectors.

III

Although the NRC investigation is continuing, based on the above, Mr. Phillips engaged in deliberate misconduct, a violation of 10 CFR 30.10, which caused the Licensee to be in violation of a number of NRC requirements including: (1) administration of radiopharmaceutical doses that differed from the prescribed doses, required by 10 CFR 35.25 and License Condition 16 ; (2) failure to provide training to nuclear medicine technologists, required by 10 CFR 19.12 ; (3) failure to perform the daily constancy checks of the dose calibrator, required by 10 CFR $35.50(b)(1)$; (4) failure to perform the required daily and weekly contamination and radiation surveys, required by 
10 CFR $35.70(a),(b)$, and (e); (5) failure to perform the required surveys for radioactive material receipt, required by 10 CFR 20.205(d) and License Condition 16; and (6) failure to maintain accurate and complete records involving NRC-licensed activities (i.e., records of dose calibrator constancy checks (10 CFR $35.50(e))$, radiation and contamination surveys

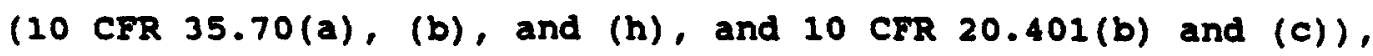
required by 10 CFR 30.9. Mr. Phillips also deliberately provided NRC inspectors information he knew to be inaccurate which was material to the NRC, also in violation of $10 \mathrm{CFR} 30.10$, which caused the Licensee to be in violation of 10 CFR 30.9 .

As the RSO for the Iicensee, Mr. Phillips was responsible, pursuant to $10 \mathrm{CFR} 35.21(\mathrm{a})$, for ensuring that radiation safety activities were being performed in accordance with approved procedures and regulatory requirements, including the administration of radiopharmaceuticals, performance of required surveys, and keeping of required records which evidence compliance with Commission requirements. The NRC must be able to rely on the Licensee and its employees to comply with NRC requirements, including the requirement to provide information and maintain records that are complete and accurate in all material respects. Mr. Phillips engaged in deliberate misconduct, a violation of 10 CFR $30.10(a)(1)$, causing the Licensee to be in violation of NRC requirements, as noted above, 
and submitted to the NRC information he knew to be incomplete or inaccurate, a violation of 10 CFR $30.10(a)(2)$.

Mr. Phillips' deliberate misconduct has raised serious doubt as to whether he can be relied upon to comply with NRC requirements and to provide complete and accurate information to the NRC. In addition, Mr. Phillips' deliberate misconduct caused this Iicensee to violate numerous Commission requirements and his deliberate false statements to Comission officials demonstrate conduct that cannot, and will not, be tolerated.

Consequently, in light of the numerous violations caused by Mr. Phillips' conduct, the length of time the noncompliances existed, and the deliberate nature of Mr. Phillips' actions, I lack the requisite reasonable assurance that licensed activities can be conducted in compliance with the commission's requirements and that the health and safety of the public would be protected if Mr. Phillips were permitted at this time to be involved in any NRC-licensed activities. Therefore, the public health, safety and interest require, pending further action by the NRC, that Mr. Phillips be prohibited from involvement in licensed activities. Furthermore, pursuant to 10 CFR 2.202 , I find that the significance of the conduct described above is such that the public health, safety and interest require that this order be immediately effective. 
Accordingly, pursuant to Sections $81,103,161 \mathrm{~b}, 1611,182$ and 186 of the Atomic Energy Act of 1954, as amended, and the Commission's regulations in 10 CFR $2.202,10$ CFR 30.10 , and 10 CFR 150.20, IT IS HEREBY ORDERED, EFFECTIVE IMOMEIATELY, THAT:

Pending further action by the NRC, Hartsell S. Phillips is prohibited from participation in any respect in NRC-licensed activities. For the purposes of this paragraph, NRC-Iicensed activities include licensed activities of: 1) an NRC licensee, 2) an Agreement State 1 icensee conducting licensed activities in NRC jurisdiction pursuant to 10 CFR 150.20, and 3) an Agreement state licensee involved in distribution of products that are subject to MRC jurisdiction.

The Director, Office of Enforcement, may, in writing, relax or rescind any of the above conditions upon demonstration by Mr. Phillips of good cause.

\section{V}

In accordance with 10 CFR 2.202, Hartsell S. Phillips must, and any other person adversely affected by this order may, submit an answer to this order, and may request a hearing on this order, within 20 days of the date of this order. The answer may consent 
to this order. Unless the answer consents to this order, the answer shall, in writing and under oath or affirmation, specifically admit or deny each allegation or charge made in this Order and shall set forth the matters of fact and law on which Hartsell S. Phillips or other person adversely affected relies and the reasons why the order should not have been issued. Any answer or request for hearing shall be submitted to the Secretary, U.S. Nuclear Regulatory Commission, Attn: Chief, Docketing and Service Section, Washington, DC 20555. Copies also shall be sent to the Director, Office of Enforcement, U.S. Nuclear Regulatory Commission, Washington, DC 20555, to the Assistant General Counsel for Hearings and Enforcement at the same address, to the Regional Administrator, NRC Region II, Suite 2900, 101 Marietta Street, NW, Atlanta, Georgia 30323, and to Hartsell S. Phillips, if the answer or hearing request is by a person other than Hartsell s. Phillips. If a person other than Hartsell S. Phillips requests a hearing, that person shall set forth with particularity the manner in which his or her interest is adversely affected by this order and shall address the criteria set forth in 10 CFR 2.714 (d).

If a hearing is requested by Hartsell s. Phillips or a person whose interest is adversely affected, the Commission will issue an order designating the time and place of any hearing. If a hearing is held, the issue to be considered at such hearing shall be whether this order should be sustained. 
Pursuant to $10 \mathrm{CFR} 2.202(C)(2)(i)$, Hartsell S. Phillips, or any other person adversely affected by this order, may, in addition to demanding a hearing, at the same time the answer is filed or sooner, move the presiding officer to set aside the immediate effectiveness of the order on the ground that the order, including the need for immediate effectiveness, is not based on adequate evidence but on mere suspicion, unfounded allegations, or error.

In the absence of any request for hearing, the provisions specified in section IV above shall be final 20 days from the date of this order without further order or proceedings. AN ANSWER OR A REQUEST FOR HEARING SHALL NOT STAY THE IMMEDIATE EFFECTIVENESS OF THIS ORDER.

FOR THE NUCLEAR REGULATORY COMMISSION

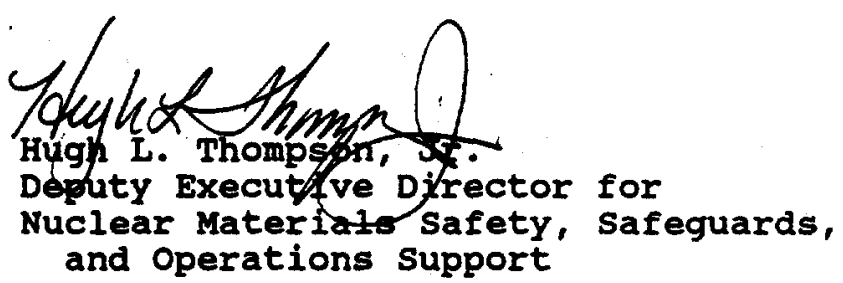

Dated at Rockville, Maryland

this $10^{\text {th }}$ day of March 1994 
UNITED STATES OF AMERICA

NUCLEAR REGULATORY COMMISSION

ATOMIC SAEETY AND LICENIING BOARD

Before Administrative Judges:

Peter B. Bloch, Chairman

Dr. Jerry R. Kline

Frederick J. Shon

\section{In the matter of}

HARTSELL D. PHILLIPS, JR. West Virginia
Docket No. IA-94-001

Re:Allegation of Deliberate Violations

ASLBP NO. 94-694-05-EA

\section{MEMORANDUM AND ORDER \\ (Dismissal Pursuant to Agreement)}

On September 14, 1995, the parties to the above-captioned proceedings, Hartsell Phillips (Phillips) and the staff of the United States Nuclear Regulatory Commission (Staff), informed the Atomic Safety and Licensing Board ("Licensing Board") of the following developments concerning this matter:

Eirst, on June 5, 1995, Mr. Phillips pled guilty to a one-count superseding Information stating a violation of law, related to the matters which are the subject of this proceeding. A copy of the United States District Court's order of June 6, 1995, adjudging Mr. Phillips to be guilty and convicting him of the count charged in the Information, is attached. Sentencing of Mr. Phillips was conducted by the

$$
\text { †วつั5งร }
$$


Court on August 22, 1995, in accordance with the Court's order of June $6,1995$.

second, the parties have reached an agreement in settlement of this proceeding. Accordingly, we approve of the stipulation in the agreement and provide the requested relief.

ORDER

For all the foregoing reasons and upon consideration of the entire record in this matter, it is this $19 t h$ day of September, 1995, ORDERED, that:

1. Hartsell D. Phillips, Jr. is permitted to withdraw his request for hearing on the staf's "Order Prohibiting Involvement in NRC-Iicensed Activities (Effective Immediately)," dated March 10, 1994, and he is dismissed as a party in the proceeding pertaining to that order; 


$$
-3-
$$

2. The attached stipulation is adopted as an order of this Board; and

3. The proceeding is dismissed with prejudice.

THE ATOMIC SAFETY AND LICENSING BOARD

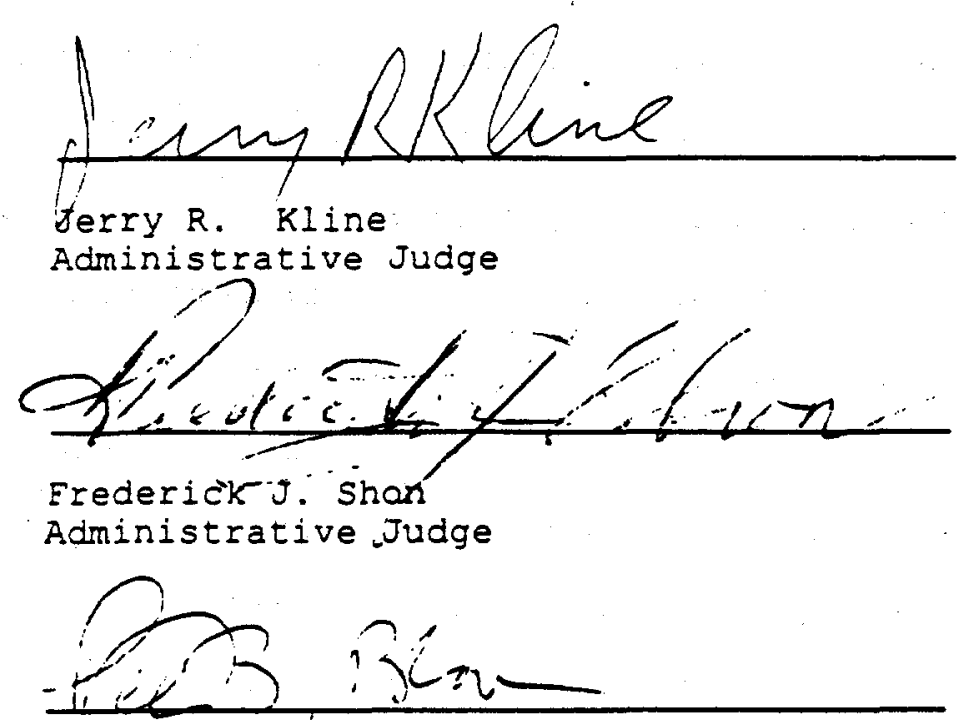

Peter B. Bloch

Chairman

Rockville, Maryland 


\section{STIPULATION EOR SETTLEMENT OF PROCEEDING}

THIS AGREEMENT is made by :nd between Hartsell Phillips ("Phillips") and the staff of the United States Nuclear Regulatory Commission ("NRC Staff" or "Staff"), to wit:

WHEREAS Logan General Hospital, Logan, West Virginia ("Logan" or the "Licensee"), holds License No. 47-19919-01 issued by the NRC pursuant to 10 C.F.R. Parts 30 and 35 , which license authorizes possession and use of byproduct material in accordance with the conditions specified therein; and

WHEREAS Phillips was employed by Logan, commencing in January 1991, as Chief Technologist, Radiation Safety officer ("RSO") and Chairman of the Radiation Safety Committee ("RSC"), with responsibilities, inter alia, involving compliance with NRC reguirements for radiation protection, until a date on which his employment was suspended by Logan in or about February 1994; and

WHEREAS on March 10, 1994, the NRC staff issued an "Order Prohibiting Involvement in NRC-Licensed Activities (Effective Immediately)," 54 Fed. Reg. 13346 (March 21, 1994), based, inter alia, upon a finding that phillips had engaged in deliberate misconduct in violation of 10 C.F.R. $\$ 30.10$, which caused the Licensee to be in violation of a number of NRC regulatory requirements; and 
WHEREAS the Order prohibited Phillips, pending further action by the NRC, from participation in any respect in NRClicensed activities, to include licensed activities of (1) an NRC licensee, (2) an Agreement State licensee conducting licensed activities in NRC jurisdiction pursuant to 10 C.F.R. $\$ 150.20$, and (3) an Agreement state licensee involved in distribution of products that are subject to NRC jurisdiction; and

WHEREAS on March 30, 1994, Phillips filed a "Request for Hearing and Answer of Hartsell D. Phillips" concerning the order, pursuant to 10 C.F.R. $\$ 2.202$, in response to which adjudicatory proceedings have been convened and remain pending before an Atomic Safety and Licensing Board ("Licensing Board") at this time; and

WHEREAS the undersigned parties recognize that certain advantages and benefits may be obtained by each of them through settlement and compromise of the matters now pending in litigation between them, including, without limitation, the elimination of further litigation expenses, uncertainty and delay, and other tangible and intangible benefits, which the parties recognize and believe to be in the public interest; and

WHEREAS, pursuant to 10 C.F.R. $\$ 2.203$, the staff and Phillips have stipulated and agreed to the following 
$-6-$

provisions for settlement of the above-captioned proceeding, subject to the approval of the Licensing Board, before the taking of any testimony or trial or a ijudication of any issue of fact or law; and

WHEREAS Phillips is willing to waive his hearing and. appeal rights regarding this matter, in consideration of the terms and provisions of this stipulation and settlement agreement; and

WHEREAS the terms and provisions of this stipulation, once approved by the Licensing Board, shall be incorporated by reference into an order, as that term is used in subsections (b) and (o) of section 161 of the Atomic Energy Act of 1954 , as amended (the "Act"), 42 U.S.C. $\$ 2201$, and shall be subject to enforcement pursuant to the Commission's regulations and Chapter 18 of the A.t, 42 U.S.C. $\$ 2271$ et seq.;

NOW, THEREFORE, IT IS STIPULATED AND AGREED AS FOLLOWS: 1. Phillips agrees to refrain from engaging in, and is hereby prohibited from engaging in, any NRC-licensed activities up to and including March 9, 1999, five years from the date of the NRC "order Prohibiting Involvement in NRCLicensed Activities (Effective Immediately)," dated March 10 , 1994. In addition to the definition of "NRC-licensed activities" set forth above, said definition is understood to include any and all activities that are conducted pursuant to 
$\cdot 7 \cdot$

a specific or general license issued by the NRC, including, but not limited to, those activities of Agreement state licensees conducted pursuant to the zuthority granted by 10 C.F.R. $\$ 150.20$.

2. For a period of five years after the above-specified. five-year period of prohibition has expired, i.e., from March 10, 1999 through March 9, 2004, Phillips shall, within 20 days of his acceptance of each and any employment offer involving NRC-licensed activities or his becoming involved in NRCiicensed activities, as defined above; provide written notice to the Director, office of Enforcement, U.S. Nuclear Regulatory Commission, Washington, D.C. 20555, of the name, address, and telephone number of the employer or the entity where he is, of will be, involved in the NRC-licensed activities, and a detailed description of his duties and the activities in which he is to be involved.

3. In the first notification provided pursuant to Paragraph 2 above, Phillips shall include a statement of his commitment to compliance with regulatory requirements and an explanation of the basis why the Commission should have confidence that he will comply with applicable NRC requirements.

4. The parties agree that, as an integral part of this stipulation and upon execution hereof, and subject to the 
$-8-$

approval of this stipulation by the Licensing Board, (a) Phillips will withdraw his March 30, 1994 request for hea:ing on the NRC Staff's Ordi:r of March 10, 1994, and (b) the parties will file a joint request for dismissal of the proceedings on that order, with prejudice, it being understood. and agreed that the staff will take no further enforcement or other action against Phillips in connection with that order.: 5. It is understood and agreed that nothing contained in this Agreement shall be binding on, or preclude lawful action by, any other Government agency or department, including, without limitation, the United States Department of Justice and/or the United States Attorney.

1 The parties recognize and agree that nothing in this Agreement shall be deemed to prohibit the NRC Staff from taking enforcement or other action (a) against Phillips for violation of this Agreement, or (b) against persons other than Phillips in connection with or related to any of the matters addressed in the Order of March 10, 1994, should the Staff determine, in its sole discretion, that it is appropriate to do so. 


\section{- 9-}

IN WITNESS WHEREOF, we set our hand and seal this 14th day of September, 1995.

FOR HARTSELI PHILLIPS:

[signed]

Charles I. Woody

Counsel for Hartsell Phillips

[signed]

Hartsell D. Phillips, Jr.
FOR THE NRC STAFF:

\section{[signed]}

Sherwin E. Turk

Counsel for NRC staff 
UAITD STATES OF AMERICA

MUCLEAR REEULATORY COImISSION

In the Mattor of

HARTSELL S. PHILLIPS

Docket No. (s) IA-94-001

\section{CERTIFICATE OF SERVICE}

I hereby certify that copies of the foregoing LB HEMO \& ORDER (LBP-95-16)

have been served upen the following persons by U.S. mail, first class, except

as otherwise noted and in accordance with the requirements of 10 CFR Sec. 2.712 .

Adninistrative Judge

Peter B. Bloch, Chatrman

Atomic Safety and Licensing Board Panal

U.S. Nuclear Regulatory Comission

Washington, DC 20555

Administrative Judge

Froderick J. Shon

Atonic Safoty and LIcensing Board Panel

U.S. Nuclear Regulatory Comission

Mashington, DC 20555

Sherwin E. Turk, Esq.

Offlce of the General counsel

Matl Stop 0-15 B 18

U.S. Nuclear Regulatory Comission

Washington, OC 20555

Dated at Rockville, Md. this

19 day of Soptembor 1995
Adainistrative Judge

Jerry R. KI Ine

Atoaic Safety and Licensing Board Panel

U.S. Nuclear Regulatory Comentssion

Washington, DC 20555

Office of Comatssion Appellate idjudication

U.S. Nuclear Regulatory Comission

Nashington, DC 20555

Charles L. Moody, Esq.

Spliman, Thomas a Battle

500 Virginia St., East, $\$ 1200$ Union Ctr Charleston, W 25321

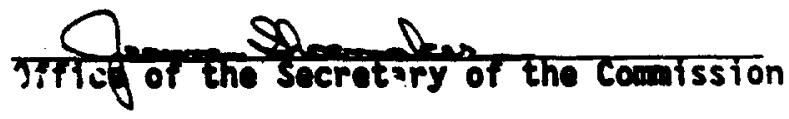




\section{UNITED STATES \\ NUCLEAR REGULATORY COMMISSION \\ WASHINGTON, D.c. asese-0001}

APR 051994

IA $94-004$

Mr. Douglas D. Preston

(Address deleted

Under 10 CFR 2.790)

Dear Mr. Preston:

SUBJECT: ORDER PROHIBITIIG INVOLVEMENT IN NRC-LICENSED ACTIVITIES (EFFECTIVE IMLEDIATELY) (NRC INSPECTION REPORT NO. 50$331 / 93020$ )

The enclosed order Prohibiting Involvement in NRC-Licensed Activities is being issued as a consequence of your deliberately providing false information on applications you made for access authorization at the Iowa Electric Iight and Power Company's (11censee) Duane Arnold Energy Center. On or about June 19, 1990, and on June 23, 1993, you indicated on your accese authorization applications that you had not been arrested or convicted of a crininal offense other than winor traffte violations. The licensee subsequently learned that you had been arrested and convicted several times for crimes other than traffic violations and that you were incarcerated for some of those offenses. As a result of your deliberate false statenents, you were granted unescorted access to the Duane Arnold facillty in 1990 and again in 1993. A licensee investigator interviewed you about the false information at which time you indicated that you had lied on your applications in 1990 and 1993 and that you would lie again about your criminal record. The deliberate false information on your criminal history in your June 23,1993 application caused you to be personally in violation of $10 \mathrm{CFR} 50.5$, "Dellberate Hisconduct".

While you deliberately made the same false statements on your access authorization application of June 19, 1990, that instance is not being clted in the enclosed order because it occurred prior to September 16, 1991, the date that 10 CFR 50.5 became effective.

Failure to comply with the provisions of the enclosed order may result in civil or criminal sanctions.

Questions concerning the order may be addressed to James Lieberman, Director, office of Enforcement. Mr. Lieberman can be reached at telephone number (301) 504-2741. 
In accordance with 10 CFR 2.790 of the NRC's "Rules of Practice", a copy of this letter and the enclosure with your home address removed will be placed in the NRC's Public Document Room.

$$
\text { sincerely, }
$$

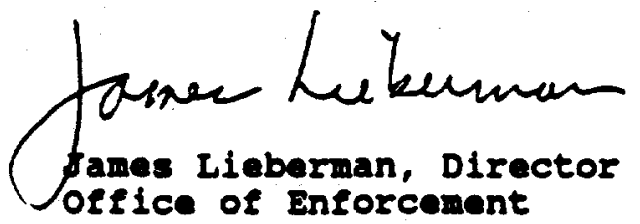

Enclosure:

order Prohibiting Involvement in

NRC-Licensed Activities (Effective Immediately)

ce w/enclosure:

L. Liu, Chairman of the Board and Chief Executive officer

D. Wilson, Plant Superintendent Nuclear Ilcensing

K. Young, Manager, Nuclear Llcensing

Resident Inepector, RIII

Stephen Brown, Iowa Department of Comnerce

Liceneing Project Managar, MRR

Berry Construction Company 
UNITED STATES

NUCLEAR REGULATORY COMAISSION

In the Matter of

MR. DOUGLAS D. PRESTON

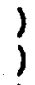

1 IA $94-004$

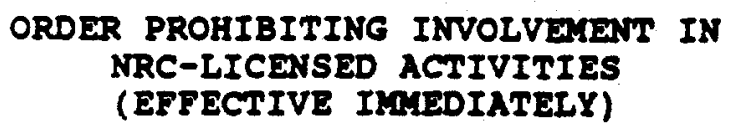

I

Mr. Douglas D. Preston was employed by the Berry Construction Company at the Iowa Electric Light and Power Company's (IELPC or Iicensee) Duane Arnold Energy Center where he was granted unescorted access. IELPC holds Facility License DPR-49, issued by the Nuclear Regulatory Commission (NRC or Comniselon) pursuant to $10 \mathrm{CFR}$ part 50 on February 22, 1974. The 11cense authorizes IELPC to operate the Duane Arnold Energy Center located near Cedar Rapids, Iowa, in accordance with the conditions specilied therein.

Mr. Preston first applied for employment with Berry Construction Company and was subsequently granted unescorted access to the Duane Arnold Enargy Center on or about June 19, 1990, based in part on the representations he made on his access authorization applications. One of the representations was that he had not been arrested and convicted for any criminal offense other than minor traffic violations. The Ilcensee submitted fingerprint cards to the Federal Bureau of Investigations (FBI) and subsequently was 
informed that $\mathrm{Mr}$. Preston had a record of arrests, convictions, and imprisonments prior to 1978. However, while waiting for the results of the FBI fingerprint check, Mr. Preston's employment at the Duane Arnold Energy Center was terminated for a lack of work. Mr. Preston's deliberate false statements on his access authorization application on or about June 19, 1990 were essentially the same as his 1993 false statements (addressed below), but are not being cited in this order as a violation because they were made before the effective date of 10 CFR 50.5 .

On June 21, 1993, Mr. Preston again applied for a position at the Duane Arnold Energy Center and was hired on June 21, 1993 by the Berry Construction Company as a laborer with responsibilities involving NRC-licensed activities. On June 23, 1993, Mr. Preston filled out an access authorization application and again denied having a criminal history. The Licensee granted Mr. Preston temporary unescorted access to the plant on br about JulY 15, 1993. on or about August 13, 1993, the Licensee received the results of a second FBI fingerprint check which again detailed Mr. Preston's criminal history. Mr. Preston, when questioned by an IELPC investigator on August 13, at first denied having a criminal history and then admitted that he had lied about his criminal history to gain employment in 1990 and again in 1993. He further stated that he would lie again to gain employment in the future. The Licensee then revoked Mr. Preston's unescorted access based on the deliberately false information regarding his criminal history 
on his access authorization application.

Based on the above, Mr. Preston engaged in deliberate misconduct on or about June 23, 1993, by deliberately falsely stating on the access authorization application that he had no criminal history for crimes other than minor traffic offenses. The commission's regulations in $10 \mathrm{CFR} 50.5$, in part, prohibit any empioyee of a contractor of a licensee from deliberately submitting to the licensee information that the employee knows to be incomplete-or inaccurate in some respect material to the NRC. Mr. Preston's actions constitute a violation of 10 CFR 50.5(a). Information concerning criminal history is material to the determination the licensee must make to meet 10 CFR $73.56(b)(2)$.

The NRC must be able to rely on the Licensee, its contractors, and the licensee and contractor employees to comply with NRC requiremente, including the requirement to provide information that is complete and accurate in all material respects. Mr. Preston's actions in deliberately providing false information to the Licensee constitute deliberate violations of commission regulations and his. statement to the Licensee that he would do it again have raised serious doubt as to whether he can be relied upon to comply with 
NRC requirements and to provide complete and accurate information to the NRC in the future.

Consequently, I lack the requisite reasonable assurance that nuclear safety activities within NRC jurisdiction can be conducted in compliance with the commission's requirements and that the health and safety of the public would be protected if Mr. Preston were permitted to be engaged in the performance of licensed activities. Therefore, the public health, safety and interest require that Mr. Preston be prohibited from being involved in the performance of activities licensed by the NRC for a five year period. In addition, Mr. Preston is required to notify the NRC, for an additional five year period, of his acceptance of employment in NRC-licensed activities so that appropriate inspections can be performed. Furthermore, pursuant to 10 CFR 2.202 , I find that the significance of the deliberate misconduct described above is such that the public health, safety and interest require that this order be immediately effective.

\section{IV}

Accordingly, pursuant to sections 103, 161b, 161i, 182 and 186 of the Atomic Energy Act of 1954, as amended, and the Commission's regulations in $10 \mathrm{CFR} 2.202$ and $10 \mathrm{CFR}$ 50.5, IT IS HEREBY ORDERED, EFFECTIVE IMLEDIATELY, THAT : 
A. Mr. Douglas D. Preston is prohibited from engaging in activities licensed by the NRC for five years from the date of this order. For the purposes of this order, licensed activities include the activities licensed or regulated by: (1) NRC; (2) an Agreement state, limited to the Licensee's conduct of activities within NRC jurisdiction. pursuant to $10 \mathrm{CFR} 150.20 ;$ and (3) an Agreement state where the licensee is involved in the distribution of products that are subject to NRC jurisdiction.

B. After the five year prohibition has expired as described in paragraph $A$ above, Mr. Preston shall provide notice to the Director, offlce of Enforcement, U.S. Nuclear Regulatory Commisaion, washington, D.C. 20555, for acceptance of any employment in licensed activity for an additional five year period.

The Regional Administrator, Region III, may, in writing, relax or rescind any of the above conditions upon demonstration by Mr. Preston of good cause.

\section{$\mathbf{v}$}

In accordance with $10 \mathrm{CFR}$ 2.202, Mr. Preston must, and any other person adversely affected by this order may, submit an answer to 
this order, and may request a hearing within 30 days of the date of this order. The answer may consent to this order. Unless the answer consents to this order, the answer shall, in writing and under oath or affirmation, specifically admit or deny each allegation or charge made in this order and shall set forth the matters of fact and law on which Mr. Preston or other person adversely affected relies and the reasons as to why the order should not have been issued. Any answer or request for a hearing shall be submitted to the Secretary, U. S. Nuclear Regulatory Commission, ATTN: Chief, Docketing and service section, Washington, DC 20555. Copies also shall be sent to the Director, office of Enforcement, U. S. Nuclear Regulatory Comission, Wachington, DC 20555, to the Assistant General Counsel for Hearings and Enforcement at the same address, to the Regional Administrator, Region III, U. S. Nuclear Regulatory Commission, 801 Warrenville Road, LIsle, Illinois 60532-4351, and to Mr. Preston, if the answer or hearing requent is by a person other than kr. Preston. If a person other than $\mathrm{Mr}$. Preston requests a hearing, that person shall set forth with particularity the manner in which his interest is adversely affected by this order and shall address the criteria set forth in $10 \mathrm{CrR} 2.714$ (d).

If a hearing is requested by Mr. Preston or a person whose interest is adversely affected, the commission will issue an order designating the time and place of any hearing. If a hearing is held, the issue to be considered at such hearing shall be whether 
this order should be sustained.

Pursuant to $10 \mathrm{CFR} 2.202(\mathrm{C})(2)(i), \mathrm{Mr}$. Preston, or any person adversely affected by this order, may in addition to demanding a hearing, at the time that answer is filed or sooner, nove the presiding officer to set aside the immediate effectiveness of the order on the ground that the order, including the need for immediate effectiveness, is not based on adequate evidence but on mere suspicion, unfounded allegations, or error.

In the absence of any request for a hearing, the provisions specified in section IV above shall be final 20 days from the date of this order without further order or proceedings. AN ANSWER OR A REQUEST FOR A HEARING SHALL NOT STAY THE IMOEDIATE EFFECTIVENESS OF THIS ORDER.

FOR THE NUCLEAR REGULATORY COMISSION

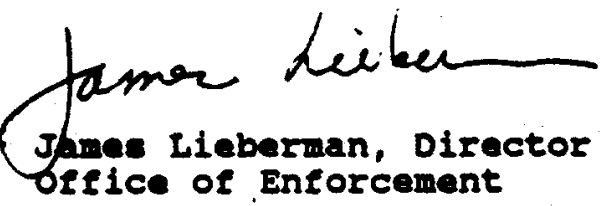

Dated at Rockille, Maryland

this 5 thday of April 1994 


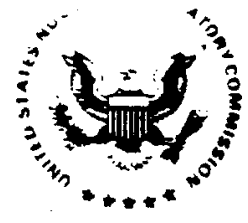

UNITED STATES

NUCLEAR REGULATORY COMMISSION

WASHINGTON, O.C. 20555-0001

$$
\text { JUN ? } 3: 094
$$

Docket No. 030-19747

License No. 52-21082-01 (expired)

IA 94-013

Guillermo Velasquez, M.O.

959 Americo Miranda

Reparto Metropolitano

(Rio Piedras) San Juan, PR 00921

Dear Dr. Velasquez:

\section{SUBJECT: CONFIRMATORY ORDER}

This is in reference to the Order to Transfer Byproduct Material to an Authorized Recipient (Effective Immediately) and Demand for Information issued by the NRC on July 21, 1993, your Answer to the Deand for Information dated September 13, 1993, and a completed NRC Form 314 dated January 241994 , notifying the NRC of the transfer of all licensed material previousiy in your possession to an authorized recipient.

In your sworn response to the Demand for Information, you stated that you did not intend to perform any licensed activities either personally or on behalf of anyone else in the future. In a telephone convorsation between Mr. Charles M. Hosey of the MRC Region II office and yourself on June 2, 1994, you agreed to the issuance of an order that would confirm that you would not participate in activities 1 icensed by the NRC for a period of three years and would contain a requirement to notify the MRC the first tian (if any) you engage in licensed activities thereafter. Based on these representations, we are issuing the enclosed Confirmatory Order.

In addition to the Confirmatory Order, we are enclosing Amendment 2 to your license which formally terminates your license.

Questions concerning the Order way be addressed to Ms. Patricia Santiago, Assistant Director for Materials, Office of Enforcement, at telephone number (301) $504-3055$. 
In accordance with 10 CFR 2.790 of the NRC's "Rules of Practice," a copy of this letter, tts enclosures, and your response will be placed in the NRC's Publis Document Room.

$$
\text { Sincerely, }
$$

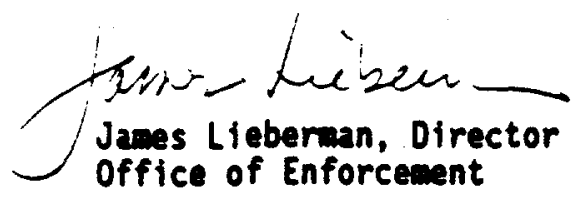

Enclosures:

1. Confirmatory Order

2. License Amendment No. 2

ce w/encls:

Commonwealth of Puerto Rico 
UNITED STATES

NUCLEAR REGULATORY COMISSION

In the Matter of

GUILLERMO VELASQUEZ, M.D.

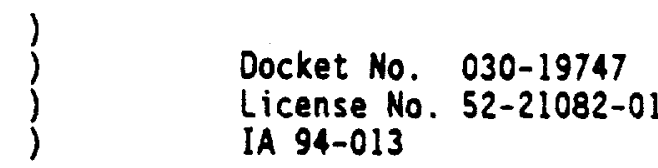

CONF IRMATORY ORDER

I

Guillermo Velasquez, M.D. (Licensee) is the holder of expired Byproduct Materials License No. 52-21082-01 (1icense) issued by the Nuclear Regulatory Comission (NRC or Comisston) pursuant to 10 CFR Parts 30 and 35 on September 3, 1982. The license authorized the use of strontiua-90 for ophthalmic radiotherapy in accordance with the conditions specified therein. The 1 icense was renewed in its entirety on August 21, 1987, and expired on August 31, 1992. The byproduct material remained in the possession of the Licensee until it was transferred to an authorized recipient on January 7 , 1994 pursuant to an MRC Order to Transfer Byproduct Material to an Authorized Recipient (Effective Imediately) and Demand for Information issued July 21 , 1993.

The Licensee did not subait an application for renewal of the license prior to its expiration, as required by 10 CFR 30.37 , nor did the Licensee notify the Comission in writing, pursuant to 10 CFR 30.36, of a dectsion not to renew the license. Therefore, on Septeaber 11, 1992, MRC Region II Issued a Notice of Violation (Notice) to the Licensee for fallure to request renewal prior to expiration of the license or to file a notice of non-renewal or transfer of 
the byproduct material. The letter forwarding the Notice directed the Licensee to place the strontium-90 in storage and to discontinue use of the material until he obtained a new NRC license. In the alternative, the Licensee was directed to transfer the material to an authorized recipient if adequate storage was not avallabie, or to subait an NRC Form 314 to the NRC if the Licensee chose to dispose of the byproduct material. During a December 4, 1992 telephone conversation between a Region II inspector and the Licensee, the Licensee stated that the source was locked in storage and that the Licensee had not used the source. The Licensee responded to the Motice on December 4, 1992, by requesting renewal of the 11cense. Because the Licensee failed to provide the appropriate licensing fee, no action was taken by the NRC to renew the license and the Licensee was notified.

The NRC performed a routine inspection of the Licensee's facility in Rio Piedras, Puerto Rico on February 24, 1993. One purpose of this inspection was to determine the status of the strontiun-90 source. The inspection revealed that the Licensee had continued to use the material (1) after expiration of the license; (2) after receipt of the MRC letter and Notice dated September 11, 1992, which directed the licensee to place the material in storage and to discontinue use of the material until a new license was obtained; and (3) after the December 4, 1992 telephone conversation with the Region II inspector when the inspector explained that the source could not be used and the Licensee had stated the source was in locked storage and not being used.

In April and May 1993, the MRC Office of Investigations conducted an investigation of the ctrcunstances surrounding the Licensee's apparent use of 
the source after the license had expired and after receiving notification from the MRC to discontinue use of the material until a new license was obtained. As a result of this investigation, it was determined that on 20 occasions, between October 9, 1992, and February 19, 1993, the Licensee, with the full understanding that use of the source was prohibited, deliberately used the strontiua-90 source for patient ophthalaic radiotherapy, in violation of 10 CFR 30.3. In addition, the investigation confirmed that the Licensee deliberately provided false information to the MRC inspector during the December 4, 1992 telephone conversation and during the inspection conducted at the Licensee's facility on February 24, 1993. Specifically, the Licensee told the NRC inspector that the strontiun-90 source had not been used for ophthalaic radiotherapy since recelpt of the Notice which was issued on September 11, 1992, when in fact the Licensee had used the strontiun-90 source at least 20 tiass between October 9, 1992 and February 19, 1993, which was as recently as five days before the inspection. This deliberate subaission of materially false information constitutes violations of 10 CFR 30.9 and 30.10 .

Based on the MRC inspection and the subsequent investigation, the MRC determined that the Licensee, by continuing to use licensed material after beting notifted of the expiration of the license which authorized that use and by deliberately providing false information to an MRC inspector, had demonstrated an unwillingness to comply with Comission requirements. The Coriatission must be able to rely on Its licensees to provide complete and accurate information. Mlliful violations are of particular concern to the 
Comission because they underwine the Comission's reasonable assurance that licensed activities are being conducted in accordance with NRC requtrements. Therefore, on July 21, 1993, the NRC issued an Order to the Licensee requiring the transfer of the strontfum-90 source to an authorized recipient within 45 days of the date of the Order. The MRC also issued a Demand for Information with the Order requiring the Licensee to submit a written statement, under oath or affirmation, stating why the MRC should have confidence that in the future the Licensee would comply with MRC requirements or provide complete and accurate information to the NRC.

The Licensee responded to the Order in letters dated September 7 and 13, 1993, and in telephone conversations with the MRC Region II staff on September 10 and 20,1993 . During these comunications, the Licensee indicated that he was making a good faith effort to transfor the byproduct aterial to an authorized reciplent. Based on this good falth effort, the NRC by letter dated October 15, 1993, extended the strontium-90 transfer date to December 6, 1993. On January 24, 1994, the Licensee subaitted a completed MRC Form 314 notifying the NRC that the strontiun-90 source had been transferred to an authorized recipient and provided the documentation required by the Order to demonstrate that the source was tested for leakage prior to the transfer and that the transfer had taken place.

On September 13,1993, the Licensee responded to the Deand for Information indicating that he did not intend to perform licensed activities or to use the strontiun-90 source in his possession, or one in anyone el se's possession. Further, in a telephone conversation on June 2, 1994, with Mr. Charles M. 
Hosey of the MRC Region II office, Dr. Velasquez agreed to the provisions and to the issuance of this Confirmatory Order. I find that the Licensee's comitments as set forth in that conversation are acceptable and necessary and conclude that with these comitments the public health and safety are reasonably assured. In view of the foregoing, I have determined that the public health and safety require that the Licensee's comitments in the telephone call of June 2, 1994 be confined by this Order.

IV

Accordingly, pursuant to Sections 81, 161b, 1611, 1610, 182 and 186 of the Atonic Energy Act of 1954, as ananded, and the Comisston's regulations at 10 CFR 2.202 and 10 CFR Parts 30 and 35, IT IS HEREBY ORDERED THAT:

1. For a period of three years from the date of this Confinatory Order, Guillerwo Velasquez, M.D., shall not supervise or engage in any way in MRC-licensed activities. MRC-llcensed activities are those activities which are conducted pursuant to a specific or general license issued by the NRC, Including, but not linited to, those activities of Agreement State licensees conducted pursuant to the authority granted by 10 CFR 150.20.

2. For a period of three years from the date of this Order, Dr. Velasquez shall provide a copy of this Order to any prospective emoloyer who engages in MRC-licensed activities (as defined in 1. above) prior to his acceptance of employment with such prospective eaployer. The purpose of 
this requirement is to ensure that the employer is aware of Dr. Velasquez' prohibition from engaging in NRC-licensed activities.

3. The first time Guillermo Velasquez, M.D., is employed in MRC licensed activities following the three year prohibition, he shall notify the Regional Adainistrator, MRC Region II, 101 Marietta Street, MW, Suite 2900, Atlanta, Georgla 30323, pritor to engaging in MRC licensed activities including activities under an Agreeant State license when activities under that license are conducted in areas of MRC jurisdiction pursuant to 10 CFR 150.20. The notice shall include the nawe, address, and telephone number of the MRC or Agreement State licensee and the location where licensed activities will be performad.

The Regional Adainistrator, MRC Region II, way, in writing, relax or rescind any of the above conditions upon a showing by the licensee of good cause.

Any person adversely affected by this Confirmatory Order, other than the Licensee, ay request a hearing within 20 days of the date of its issuance. Any request for a hearing shall be subaitted to the Secretary, U.S. Nuclear Regulatory Comisston, ATTM: Chief, Docketing and Service Section, Mashington, D.C. 20555. Coples shall be sent to the Otrector, Office of Enforcesent, U. S. Nuclear Regulatory Comission, Mashington, O.C. 20555, to the Assistant General Counsel for Hearings and Enforcement at same address, and to the Regional Adaintstrator, MRC Region II, 101 Marietta Street, M, Suite 2900, 
Atlanta, Georgia 30323 and to the Licensee. If such a person requests a hearing, that person shall set forth with particularity the manner in which his interest is adversely affected by this Order and shall address the criteria set forth in 10 CFR $2.714(d)$.

If a hearing is requested by a person whose interest is adversely affected, the Comission will issue an Order designating the time and place of any hearing. If a hearing is held, the issue to be considered at such hearing shall be whether this Confinmatory Order should be sustained.

In the absence of any request for hearing, the provisions specified in Section $\checkmark$ above shall be final 20 days from the date of this Order without further order or proceedings.

FOR THE NUCLEAR REGULATORY COMISSION

Dated at Rockville, Maryland this, day of June 1994

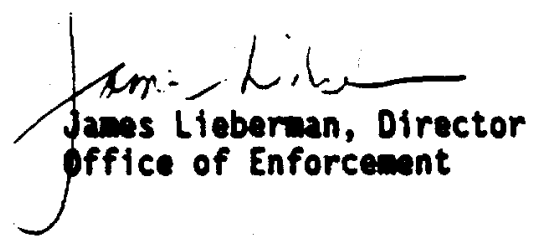




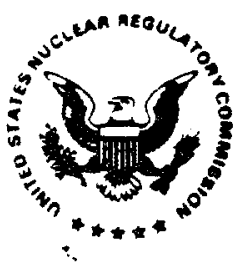

UNITED STATES

NUCLEAR REGULATORY COMMISSION

WASHINGTON, O.C. 20555-0001

APP 211994

Docket No. 55-30849

License No. SOP-30516-01

IA $94-006$

Mr. David Tang Wee

[Home Address Deleted

Under 10 CFR 2.790]

Dear Mr. Tang Wee:

SUBJECT: ORDER PROHIBITING INVOLVEMENT IN NRC-LICENSED

ACTIVITIES (EFFECTIVE IMMEDIATELY

(NRC INSPECTION REPORT NO. 50-237/92033; 50-249/92033;

NRC INVESTIGATION REPORT NO. 3-92-055R)

The enclosed order is being issued as a consequence of events. which occurred during operation of the Dresden Nuclear station Unit 2 on September 18,1992 and in violation of Nuclear

Regulatory Commission (NRC or Commission) regulations and of the Dresden Technical Specifications. The NRC conducted an inspection and an investigation of the event. The investigation by the NRC's office of Investigations (OI) concluded that on September 18, 1992 you deliberately violated or caused violations of NRC requirements and the Dresden Technical Specifications. A copy of the synopsis of the OI report was forwarded to you by letter dated November 4, 1993. An enforcement conference was held with you on November 17, 1993.

On September 18, 1992, a rod mispositioning event occurred when a Nuclear station operator (NSO) moved a control rod out of sequence during your shift as the station Control Room Engineer (SCRE). The error was noticed by a Qualified Nuclear Engineer (QNE). The NSO continued to move control rods in violation of station procedures, at the QNE's direction and without your knowledge or authorization, after which the QNE informed you of the mispositioned rod. Subsequently, you, the NSO, the QNE, and the two nuclear engineers in training who were present during the incident, agreed not to tell anyone else about the mispositioned rod incident. As a result, neither the mispositioned rod nor the subsequent deviation from the planned control rod pattern were documented in the control room log, a Dresden Form 14-14C was falsified, and Commonwealth Edison Company (CECO) management was not informed of the incident. The OI investigation also concluded, based on the testimony of three other individuals involved in the september 18, 1992 incident, that you deliberately provided inaccurate information to NRC investigators 
during your transcribed interview on December 1,1992 when you denied making a statement to the effect that the information about the mispositioned control rod should not leave the control room.

Your actions in connection with the attempt to conceal the September 18, 1992 event caused CECo to be in violation of its license conditions, including technical specifications and administrative procedures, and constituted a violation of $10 \mathrm{CFR}$ 50.5 (a), "Deliberate Misconduct". Furthermore, your provision of inaccurate information which was material to NRC investigators constituted a violation of 10 CFR 55.9," Completeness and Accuracy of Information".

NRC does not have the requisite reasonable assurance that licensed activities will be properly conducted in accordance with regulatory requirements, including the requirement to provide information that is complete and accurate in all material respects, with you involved in licensed activities.

Consequently, after consultation with the Commission, I have been authorized to issue the enclosed order Prohibiting Involvement in NRC-Licensed Activities (Effective Immediately). Failure to comply with the provisions of this order may result in civil or criminal sanctions.

Questions concerning the enclosed order may be addressed to James Lieberman, Director, office of Enforcement. Mr. Lieberman can be reached at telephone number (301) 504-2741.

In accordance with 10 CFR 2.790 of the NRC's "Rules of Practice," a copy of this letter and the enclosure with your home address removed will be placed in the NRC's Public Document Room.

sincerely,

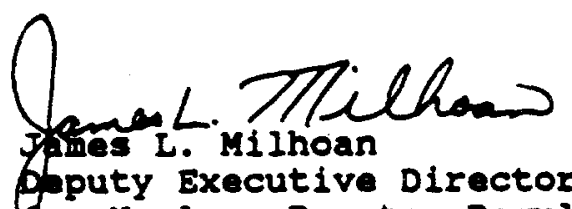

(or Nuclear Reactor Regulation, Regional Operations and Research

Enclosure:

order Prohibiting Involvement

in NRC-Licensed Activities

(Effective Immediately)

cc w/enclosure: See Next Page

NUREG-0940, PART I A250 
UNITED STATES

NUCLEAR REGUTATORY COMMISSION

In the Matter of

David Tang Wee

Tinley Park, Illinois
Docket No. 55-30849

License No. SOP-30516-01

IA $94-006$

ORDER PROHIBITING INVOLVEMENT IN

NRC-LICENSED ACTIVITIES

(EFFECTIVE IMMEDIATELY)

I

Mr. David Tang Wee (Licensee) held Senior Reactor Operator's

License No. SOP-30516-01 (License), issued by the U.S. Nuclear

Regulatory Commission (NRC or Commission) on August 14, 1985.

Mr. Tang wee was employed by Commonwealth Edison Company (CECO)

between June 22, 1981 until his employment was terminated by CECO on December 2, 1992, an action which terminated 11cense sop30516-01. The Licensee most recently held the position of Station Control Room Engineer (SCRE) with responsibilities involving compliance with NRC requirements for the operation of a nuclear power plant. CECo holds Facility Licenses DPR-19 and DPR-25 issued by the Nuclear Regulatory Commission (NRC or Commission) pursuant to $10 \mathrm{CFR}$ Part 50. These licenses authorize CECo to operate the Dresden Nuclear Station Units 2 and 3 located near Morris, Illinois.

On November 24, 1992, CECo notified the NRC that CECo senior managers had just become aware of an incident that had occurred on September 18, 1992 when Unit 2 was operating at 75 power. A Nuclear station Operator (NSO), who was a licensed reactor 
operator, incorrectly positioned control rod H-I while repositioning control rods to change localized power levels within the reactor core, and the event was concealed from CECo management. Both CECO and the NRC initiated investigations of the incident.

On september 18, 1992, the NSO erroneously moved control rod $\mathrm{H}-1$ from Position 48 (fully withdrawn) to Position 36. A Qualified Nuclear Engineer (QNE) and two individuals in training to become "qualified" nuclear engineers were in the control room when the QNE recognized the NSO's error. The QNE informed the NSO of the error. The Nso failed to insert the mispositioned rod to Position 00 and continued to move other control rods at the direction of the QNE. The QNE then informed Mr. Tang Wee, the Station Control Room Engineer on duty, of the mispositioned rod. Later, Mr. Tang Wee spoke with the NSO and the three nuclear engineers and they all agreed that they would not discuss the incident with anyone else. As a result, neither the mispositioned rod nor the subsequent deviation from the planned control rod pattern were documented in the control room log, a Dresden Porm 14-14C was falsified, and CECo management was not informed of the incident.

The NRC licenses individuals pursuant to 10 CFR part 55 , "Operators' Ilcenses," to manipulate the controls of an utilization facility. The operator license requires the 
individual to observe all applicable rules, regulations and orders of the Commission, including the operating procedures and other conditions specified in the facility license.

Dresden Technical Specification 6.2.A.1 stated that applicable procedures recommended in Appendix A of Regulatory Guide 1.33, Revision 2 dated February 1978, shall be established, implemented, and maintained. Regulatory Guide 1.33 Appendix A.1.C included administrative procedures, general plant operating procedures, and procedures for startup, operation, and shutdown of safety related systems.

Dresden Operating Abnormal Procedure (DOA) 300-12, "Mispositioned Control Rod," Revision 2, dated November 1991, section D "Subsequent operator Actions," step 2, required, in part, that if a single control rod was inserted greater than one even notch from its in-sequence position and reactor power was greater than 20\%, then the mispositioned rod must be continuously inserted to position 00. Section D.5 required, in part, that the Nso record any mispositioned control rod in the Unit log book.

Dresden Adinistrative Procedure, (DAP) 07-29, "Reactivity Management Controls," Revision 0 , section F.1.g required, in part, that the station control room engineer (SCRE) communicate to the NSo the requirements for procedural adherence. 
Dresden Adeinistrative Procedure, (DAP) 07-01, "Operations Department Organization", Section B.5.e., requires in part that the SCRE report any abnormal operating conditions to the shift Engineer.

These procedures were not followed. Specifically, Mr. Tang wee did not communicate to the Nso requirements for procedural adherence concerning the NSO's duty to record the mispositioning incident in the unit control room log, and did not report the mispositioning incident to the Shift Engineer. Instead, Mr. Tang Wee agreed with the NSO, the QNE and two nuclear engineers in training that they would not discuss the incident with anyone else.

Based on the NRC Office of Investigations (OI) investigation of this matter (OI Report No. 3-92-055R), I conclude that Mr. Tang Wee, along with the NSO, the QNE and two nuclear engineers in training, deliberately attempted to conceal the mispositioned control rod event by failing to document and report the incident as required by plant procedures. In furtherance of this agreement, m. Tang wee deliberately caused cECo to be in viclation of Dresden Technical Specification 6.2.A.1; DAP 07-29, Revision 0, section F.1.g; and DAP 07-01, Section B.5.e, by falling to communicate to the Nso the requirement to record the mispositioned rod event in the control room $\log$ and by failing to report the event to the Shift Engineer. 
Further, in a transcribed sworn statement on December 1, 1992 , Mr. Tang wee stated that he did not have a reason to make, and did not believe he made, a statement to the effect that information about the mispositioned control rod should not leave the control room. Based on the transcribed testimony of three individuals who were present during the incident that Mr. Tang Wee had made a statement to them to the effect that information about the mispositioned control rod should not leave the control room, and that all five individuals had agreed not to discuss the event with anyone else, I conclude that Mr. Tang Wee's testimony to the contrary constituted the deliberate provision of inaccurate information material to the NRC in violation of 10 CFR 55.9, "Completeness and Accuracy of Information."

Based on the above, Mr. Tang Wee, an employee of CECo at the time of the event, engaged in deliberate misconduct which caused CECo to be in violation of its license conditions and which constitutes a violation of $10 \mathrm{cFR}$ 50.5. Further, Mr. Tang Wee, a licensed sanior reactor operator at the time of the event, deliberately provided to NRC Investigators information which he knew to be inaccurate in some respect material to the NRC, in violation of $10 \mathrm{CFR} 55.9$. 
The NRC wust be able to rely on its licensees and their employees, especially NRC-licensed operators, to comply with NRC requirements, including the requirement to provide information and maintain records that are complete and accurate in all material respects. Mr. Tang Wee's action in causing CECo to violate its license conditions and his misrepresentations to the NRC have raised serious doubt as to whether he can be relied upon to comply with NRC requirements applicable to licensed facilities and $l i c e n s e d$ individuals and to provide complete and accurate information to the NRC. Mr. Tang Wee's deliberate misconduct that caused CECo to violate Commission requirements, and his false statements to Commission officials, cannot and will not be tolerated.

Consequently, I lack the requisite reasonable assurance that licensed activities can be conducted in compliance with the Commission's reguiraments and that the health and safety of the public will be protected, if $\mathrm{kr}$. Tang wee were permitted at this time to be engaged in the performance of NRC-licensed and regulated activities. Therefore, the public health, safety and interest require that $\mathrm{kr}$. Tang wee be prohibited from being involved in any aRC-licensed activities for three years from the date of this order. In addition, for the same period, Mr. Tang wee is required to give notice of this order to any prospective employer engaged in NRC-licensed activities as described in section IV, Paragraph B, below, from whom he seeks 
employment in non-licensed activities in order to ensure that such employer is aware of Mr. Tang Wee's previous history. For five years from the date of the order, Mr. Tang wee is also required to notify the NRC of his employment by any person engaged in licensed activities, as described in section IV, Paragraph B, below, so that appropriate inspections can be performed. Furthermore, pursuant to $10 \mathrm{CFR} 2.202$, I find that the significance of the conduct described above is such that the public health, safety and interest require that this order be immediately effective.

IV

Accordingly, pursuant to sections 103, 107, 161b, 1611, 1610, 182 and 186 of the Atomic Energy Act of 1954, as amended, and the Commission's regulations in 10 CFR $2.202,10$ CFR 50.5, and 10 CFR 55.61, IT IS HEREBY ORDERED, EFFECTIVE IMOAEDIATELY, THAT:

A. Mr. Tang wee is prohibited for three years trom the date of this order from engaging in activities licensed by the NRC.

B. Should Mr. Tang wee seek employment in non-licensed activities with any person engaged in MRC-licensed activities in the three years from the date of this order, Mr. Tang wee shall provide a copy of this order 
to such person at the time Mr. Tang Wee is soliciting or negotiating employment so that the person is aware of the order prior to making an employment decision. For the purposes of this order, licensed activities include the activities of: (1) an NRC licensee; (2) an Agreement State licensee conducting licensed activities in NRC jurisdiction pursurant to $10 \mathrm{CFR} 150.20$; and (3) an Agreement state licensee involved in the distribution of products that are subject to NRC jurisdiction.

c. For three years from the date of this order, Mr. Tang wee shall provide notice to the Director, office of Enforcement, U. S. Nuclear Regulatory Commission, Washington, DC 20555, of the name, address, and telephone number of the employer, within 72 hours of his acceptance of an employment offer involving non-licensed activities from an employer engaged in NRC-licensed activities, as described in Paragraph IV.B, above.

D. After the three year prohibition has expired as described in Paragraphs IV.A and B, above, Mr. Tang Wee shall provide notice to the Director, office of Enforcement, of acceptance of any employment in NRClicensed activity for an additional two year period. 
The Director, office of Enforcement may, in writing, relax or rescind any of the above conditions upon demonstration by Mr. Tang Wee of good cause.

In accordance with $10^{\circ} \mathrm{CFR} 2.202$, Mr. Tang Wee must, and any other person adversely affected by this order may, submit an answer to this Order, and may request a hearing within 30 days of the date of this order. The answer may consent to this order. Unless the answer consents to this order, the answer shall, in writing and under oath or affirmation, specifically admit or deny each allegation or charge made in this order and shall set forth the matters of fact and law on which Mr. Tang wee or other person adversely affected relies and the reasons as to why the order should not have been 1ssued. Any answer or request for a hearing shall be submitted to the Secretary, U. S. Nuclear Regulatory Commission, ATTW: Chiet, Docketing and service section, Washington, DC 20555. Copies also shall be sent to the Director, ofsice of Enforcenent, U. S. Nuclear Regulatory Commission, Washington, DC 20555; to the Assistant General Counsel for Hearings and Enforcement at the same address; to the Regional Administrator, Region III, U. S. Nuclear Regulatory Commission, 801 Warrenville Road, Lisle, Illinois 60532-4351; and to $\mathrm{kr}$. Tang wee, if the answer or hearing request is by a person other than Mr. Tang Wee. If a person other than Mr. Tang wee 
requests a hearing, that person shall set forth with particularity the manner in which his interest is adversely affected by this order and shall address the criteria set forth in 10 CFR 2.714 (d).

If a hearing is requested by Mr. Tang wee or a person whose interest is adversely affected, the commission will issue an order designating the time and place of any hearing. If a hearing is held, the issue to be considered at such hearing shall be whether this order should be sustained.

Pursuant to $10 \mathrm{CFR} 2.202(\mathrm{C})(2)(1)$, Mr. Tang wee, or any person adversely affected by this order, may in addition to demanding a hearing, at the time that answer is filed or sooner, move the prestding officer to set aside the immediate effectiveness of the order on the ground that the order, including the need for immediate effectiveness, is not based on adequate evidence but on mere suspicion, unfounded allegations, or error.

In the absence of any request for a hearing, the provisions specified in section IV above shall be final 20 days from the date of this order without further order or proceedings. AN 
ANSWER OR A REQUEST FOR A HEARING SHALL NOT STAY THE IMDEDIATE EFFECTIVENESS OF THIS ORDER.

FOR THE NUCLEAR REGULATORY COMMISSION

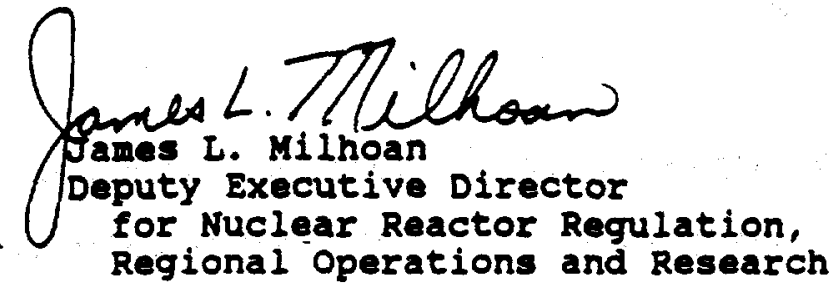

Dated at Rockville, Maryland

this 2$)^{31}$ day of April 1994 


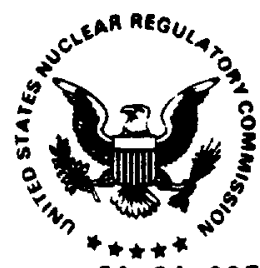

UNITED STATES

\section{NUCLEAR REGULATORY COMMISSION}

WASHINGTON, D.C. 20658-0001

December 12, 1994

IA $94-035$

Mr. Rex Allen Werts

(Address deleted

under 10 (FR 2.790)

SUBJECT: ORDER PROHIBITING INVOLVEMENT IN NRC-LICENSED ACTIVITIES

AND UNESCORTED ACCESS (EFFECTIVE IMMEDIATELY)

OI INVESTIGATION REPORT SYNOPSIS (2-93-052R)

Dear Mr. Werts:

The enclosed Order Prohibiting Involvement in NRC-Licensed Activities and Unescorted Access (Effectively Immediately) is being issued as a consequence of the deliberate false statements you made on an application for access authorization at the Carolina Power and Light Company's (Licensee) Brunswick Nuclear Plant. On or about March 11, 1993, you used an alias on your access authorization application and indicated on the application that you had not been arrested or convicted of any criminal offense. As a result of your deliberate false statements, you were granted unescorted access to the Brunswick Nuclear Plant on March 24, 1993. The Licensee subsequently learned of your use of an allas and that you had been arrested and convicted several times for crimes and were incarcerated for some of those offenses. A licensee supervisor interviewed you about your application, at which time you admitted that you had submitted false information on your application.

10 CFR 50.5(a)(2), "Deliberate misconduct," prohibits an employee of an NRC licensee or licensee contractor from deliberately submitting information to the licensee or licensee contractor that the employee knows to be incomplete or inaccurate in some respect material to the NRC. 10 CFR Part 2, Appendix C, "General Statement of Policy and Procedures for NRC Enforcement Actions," in particular Section VIII, "Enforcement Action Involving Individuals," provides guidance and considerations for enforcement sanctions against individuals who deliberately violate NRC requirements.

The NRC Office of Investigations (OI) conducted an investigation (2-93-052R) to determine whether you committed a willful violation in connection with your making false statewents regarding your criminal background. The oI

investigation concluded that you had deliberately provided false information concerning your criminal arrest and conviction record in order to gain unescorted access to the site protected area. By letter dated September 14, 1994, the NRC attempted to provide you with a copy of the OI investigation synopsis and afford you an opportunity for an enforcement conference prior to making a final decision regarding escalated enforcement action in your case. The letter has been returned by the post office as undeliverable and we have been unable to locate you. A copy of the September 14, 1994, letter with the 01 synopsis attached is enclosed (Enclosure 1). If attempts to deliver this letter and the enclosed Order are not successful, it will not delay the effective date of the enclosed Order nor the placement of this letter and enclosed Order in the Public Document Room. 
The false information you provided regarding your criminal history on the March 11, 1993 access authorization application is a violation of 10 CFR 50.5 , "Deliberate misconduct." Such conduct is unacceptable to the NRC. Therefore, after consultation with the Commission, I have been authorized to issue the enclosed Order Prohibiting Involvement in NRC-Licensed Activities and Unescorted Access (Effective Immediately). Pursuant to section 223 of the Atomic Energy Act of 1954, as amended, any person who willfully violates, attempts to violate, or conspires to violate, any provision of this order shall be subject to criminal prosecution as set forth in that section.

You are required to provide a response to this Order and should do so within 20 days. Questions concerning the Order may be addressed to James Lieberman, Director, Office of Enforcement. Mr. Lieberman can be reached at telephone number (301) 504-2741.

In accordance with 10 CFR 2.790 of the NRC's "Rules of Practice," a copy of this letter with your home address removed, its enclosures and any response will be placed in the NRC's Public Document Room (PDR). To the extent possibie, your response should not include any personal privacy, proprietary, or safeguards information so that it can be placed in the PDR without redaction. However, if you find it necessary to include such information, you should clearly indicate the specific information that you desire not to be placed in the POR, and provide the legal basis to support your request for withholding the information from the public.

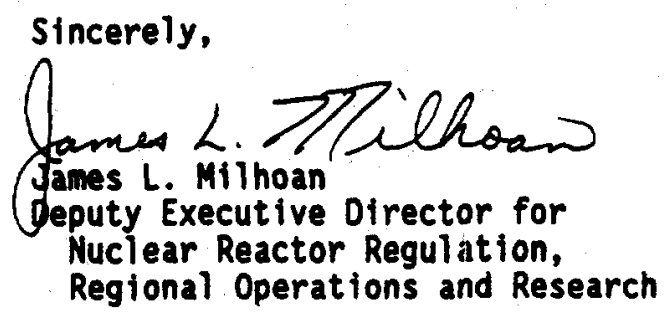

Enclosures: 1. September 14, 1994 letter with or synopsis

2. Order Prohibiting Involvement in NRC-Licensed Activities and Unescorted Access (Effective Immediately)

cc w/encls: (See next page) 
In the Matter of

REX ALLEN WERTS

(A) so KnOWn As:

MICHAEL ALLEN HUNTER)

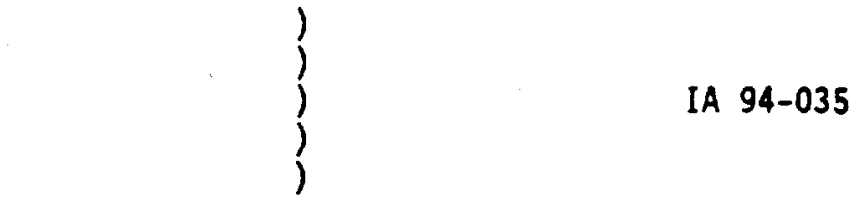

ORDER PROHIBITING INVOLVEMENT IN

NRC-LICENSED ACTIVITIES AND UNESCORTED ACCESS

(EFFECTIVE IMMEDIATELY)

\section{I}

Mr. Rex Allen Werts (Also Known As: Michael Allen Hunter) was employed by Power Plant Maintenance, Inc., (PPM) a contractor of the Carolina Power and Light Company (CP\&L or Licensee), from March 24, 1993 until his unescorted access was revoked on July 26, 1993. Licensee is the holder of License Nos. DPR-62 and DPR-71 issued by the Nuclear Regulatory Commission (NRC or Commission) pursuant to 10 CFR Part 50 on December 27, 1974 and November 12, 1976, respectively. The licenses authorize the operation of the Brunswick Nuclear Plant in accordance with the conditions specified therein. The facility is located on the Licensee's site in Southport, North Carolina.

On March 24, 1993, Mr. Merts was granted unescorted access to the Brunswick Nuclear Plant, based in part on representations he made on an access authorization application, dated March 11, 1993, which he submitted to Power Plant Maintenance, Inc., (PPM), a contractor of the Licensee. In the application, Mr. Herts falsely represented himself as Michael Allen Hunter and stated that he had not been arrested or convicted of any criminal offense. In addition, Mr. Werts failed to correct that information after he was granted unescorted access and continued to hold that status on the basis of his false 
identity. The Licensee submitted fingerprint cards completed by Mr. Werts to the Federal Bureau of Investigation (FBI) and subsequently was informed that Mr. Werts (alias Mr. Hunter) had a record of arrests, convictions, and imprisonments prior to 1990 .

Based on the above, Mr. Werts engaged in deliberate misconduct in violation of 10 CFR 50.5(a)(2) which prohibits any employee of a licensee or licensee contractor from deliberately submitting to the licensee or licensee's contractor information the employee knows to be incomplete or inaccurate in some respect material to the NRC. Information concerning an individual's true identity and criminal history is material in that it is used by the Licensee to make determinations relative to the grant or denial of access authorization. If the Licensee had been given accurate information regarding Mr. Werts' criminal record, the Licensee would not have granted unescorted access to Mr. Werts.

The NRC must be able to rely on the Licensee, its contractors, and licensee and contractor employees to comply with NRC requirements, including the requirement to provide information that is complete and accurate in all material respects. Mr. Werts' actions have raised serious concerns as to whether he can be relied upon to comply with NRC requirements and to provide complete and accurate information to the NRC or to NRC licensees in the future.

Consequently, I lack the requisite reasonable assurance that nuclear safety activities can be conducted in compliance with the comission's requirements 
and that the health and safety of the public would be protected if Mr. Werts were permitted at this time to be involved in the performance of licensed activities or were permitted unescorted access to protected or vital areas of NRC-licensed facilities. Therefore, the public health, safety and interest require that $\mathrm{Mr}$. Werts be prohibited from being involved in the performance of activities licensed by the NRC and be prohibited from obtaining unescorted access for a period of three years from the-date of this order. For a period of five years from the date of this Order, Mr. Werts is required to inform the NRC of his acceptance of employment with any employer whose operations he knows or has reason to believe involve NRC-licensed activities. Furthermore, pursuant to 10 CFR 2.202, I find that the significance of the deliberate misconduct described above is such that the public health, safety and interest require that this Order be immediately effective.

IV

Accordingly, pursuant to sections 103,161b,161i, 182 and 186 of the Atomic Energy Act of 1954, as anended, and the Commission's regulations in 10 CFR 2.202, 10 CFR 50.5, and 10 CFR 150.20, IT IS HEREBY ORDERED, EFFECTIVE IMMEDIATELY, THAT:

A. For a three-year period from the date of this Order, Mr. Rex Allen Werts is prohibited from engaging in activities licensed by the NRC and is prohibited from obtaining unescorted access to protected and vital areas of facilities licensed by the NRC. For the purposes of this Order, licensed activities include the 
activities licensed or regulated by: (1) NRC; (2) an Agreement State, limited to the Licensee's conduct of activities within NRC jurisdiction pursuant to 10 CFR 150.20; and (3) an Agreement State where the licensee is involved in the distribution of products that are subject to NRC jurisdiction.

B. For a five-year period from the date of this Order, Mr. Warts is required to provide notice to the Director, Office of Enforcement, U.S. Nuclear Regulatory Commission, Washington, D.C. 20555, of his acceptance of employment with any employer whose operations he knows or has reason to believe involve NRC-licensed activities.

The Director, Office of Enforcement, may, in writing, relax or rescind any of the above conditions upon demonstration by Mr. Werts of good cause.

\section{V}

In accordance with 10 CFR 2.202, Mr. Werts must, and any other person adversely affected by this Order may, submit an answer to this Order, and may request a hearing on this Order, within 20 days of the date of this Order. The answer may consent to this Order. Uniess the answer consents to this Order, the answer shall, in writing and under oath or affirmation, specifically adnit or deny each allegation or charge made in this Order and shall set forth the matters of fact and law on which Mr. Werts or other person adversely affected relies and the reasons as to why the Order should not have been issued. Any answer or request for a hearing shall be submitted to the 
Secretary, U.S. Nuclear Regulatory Commission, ATTN: Chief, Docketing and Services Section, Washington, DC 20555. Copies also shall be sent to the Director, Office of Enforcement, U.S. Nuclear Regulatory Commission, Washington, DC 20555, to the Assistant General Counsel for Hearings and Enforcement at the same address, to the Regional Administrator, Region II, U.S. Nuclear Regulatory Commission, 101 Marietta St. N.W., Atlanta, Georgia 30323, and to Mr. Werts, if the answer or hearing request is by a person other than Mr. Werts. If a person other than Mr. Werts requests a hearing, that person shall set forth with particularity the manner in which his interest is adversely affected by this Order and shall address the criteria set forth in 10 CFR 2.714(d).

If a hearing is requested by Mr. Werts or a person whose interest is adversely affected, the Commission will issue an Order designating the time and place of any hearing. If a hearing is held, the issue to be considered at such hearing shall be whether this Order should be sustained.

Pursuant to 10 CFR 2.202(c)(2)(i), Mr. Werts, or any other person adversely affected by this Order, may, in addition to demanding a hearing, at the time the answer is filed or sooner, move the presiding officer to set aside the immediate effectiveness of the Order on the ground that the Order, including the need for Imediate effectiveness, is not based on adequate evidence but on mere suspicion, unfounded allegations, or error.

In the absence of any request for a hearing, the provisions specified in Section IV above shall be final 20 days from the date of this Order without 
further order or proceedings. AN ANSWER OR A REQUEST FOR A HEARING SHALL NOT STAY THE IMMEDIATE EFFECTIVENESS OF THIS ORDER.

FOR THE NUCLEAR REGULATORY COMISSION

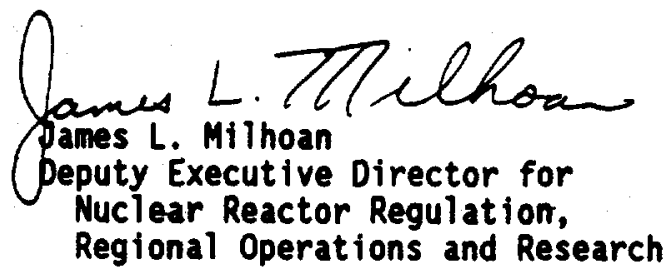

Dated at Rockville, Maryland this Lithay of December 1994 


\section{SYNOPSIS}

On August 20, 1993, the U.S. Nuclear Regulatory Commission (NRC) Ticensee, Carolina Power and Light Company, submitted a Security Event Report to the NRC regarding an event at the licensee's Brunswick Nuclear Plant (BNP). The event described by the licensee involved an employee of a contractor who was granted unescorted access to the BNP vital and protected areas based on falsified employment and background information. This matter was referred to the NRC Office of Investigations (OI) Region II Field Office on September 1, 1993, for evaluation.

Based on OI review of the documentation and evidence obtained in this investigation. it is concluded that the subject deliberately falsified personal identification and background information to deceive the contractor. PPM, the licensee and the NRE in order to fraudulently obtain employment and unescorted access at the BNP. 


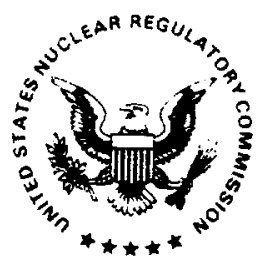

\section{UNITED STATES}

\section{NUCLEAR REGULATORY COMMISSION}

WASHINGT; V. D.C. 20555-0001

September 27, 1994

IA $94-024$

Larry D. Wicks, President

Western Industrial $X$-Ray Inspection Company, Inc.

5354 Highway 89 North

Evanston, Wyoming 82931

SUBJECT: ORDER PROHIBITING INVOLVEMENT IN NRC-LICENSED ACTIVITIES (EFFECTIVE IMMEDIATELY)

The enclosed Order Prohibiting Involvement in NRC-Licensed Activities

(Effective Immediately) is being issued because you engaged in deliberate misconduct as defined in 10 CFR 30.10. As described in the Order in more detail, the NRC has concluded that you deliberately failed to send an employee's thermoluminescent dosimeter (TLD) in for processing after you learned of an incident on July 31, 1993; that you deliberately failed to perform an evaluation of this employee's radiation exposure after becoming aware of the incident; that you were not truthful in responding to NRC inspectors and investigators about this incident; and that you deliberately failed to ensure that properly calibrated alarm ratemeters were provided and used by your radiography personnel. A copy of the synopsis of the 01 report is enclosed.

The Order prohibits your involvement in NRC-licensed activities for a period of five years from the date of the Order, except as necessary to maintain licensed material in possession of WIX in safe storage or to transfer that material to an authorized recipient. Other than this exception, you are prohibited from any involvement in managing, supervising, or performing activities that are regulated by the NRC, including conducting or supervising radiography activities and acting as a Radiation Safety officer for an NRC licensee.

Failure to comply with the provisions of this Order may result in further civil or criminal sanctions.

Questions concerning this Order should be addressed to Mr. James Lieberman, Director, Office of Enforcement, who can be reached at (301) 504-2741. 
In accordance with 10 CFR 2.790 of the NRC's "Rules of Practice", a copy of this letter and the enclosures will be placed in the NRC's Public Document Room.

FOR THE NUCLEAR REGULATORY COMMISSION

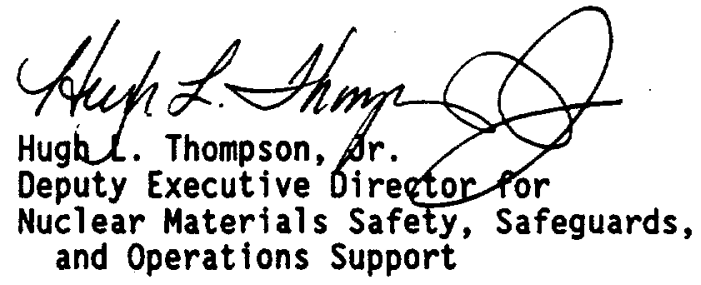

Docket No. 030-32190

License No. 49-27356-01

IA 94-024

Enclosures:

1. Order

2. OI synopsis

cc w/enclosures: State of Wyoming 
UNITED STATES

NUCLEAR REGULATORY COMMISSION

In the Matter of

LARRY D. WICKS

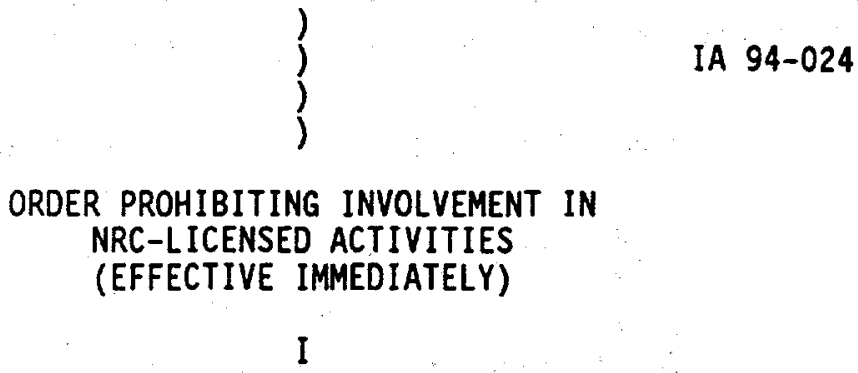

Larry D. Wicks is the President and Radiation Safety Officer for Western Industrial X-Ray Inspection Company, Inc. (WIX), Evanston, Wyoming. WIX holds License No. 49-27356-01 issued by the Nuclear Regulatory Commission (NRC or Commission) pursuant to 10 CFR Parts 30 and 34 . The license authorizes the licensee to possess sealed sources of iridium-192 in various radiography devices for use in performing industrial radiography in accordance with the conditions of the license. The license was suspended by NRC Order on June 16, 1994, and remains suspended while a hearing requested by the licensee is pending.

The suspension of License No. 49-27356-01 was based on the results of NRC staff inspections and Office of Investigations (OI) investigations of WIX conducted in April 1993 and in January and March 1994. These inspections and investigations identified numerous violations of NRC's radiation safety requirements, including some violations that were found to have recurred after being identified in previous inspections and some which were found to have been committed deliberately by Mr. Wicks and other employees of WIX. These violations were described in inspection reports $030-32190 / 93-01$ and 
030-32190/94-01 issued on May 12, 1994, and were the subject of an enforcement conference held April 1, 1994 in Arlington, Texas, during which Mr. Wicks was given the opportunity to provide additional information concerning each violation. In Investigation Report 4-93-017R, issued August 2, 1993, OI found three deliberate violations and in Report 4-93-049R, issued July 8, 1994, OI found four deliberate violations.

Based on its review of all available information, the NRC concludes that $\mathrm{Mr}$. Wicks violated the provisions of 10 CFR 30.10 , which prohibits individuals from deliberately causing a licensee to violate NRC requirements and from deliberately providing materially incomplete or inaccurate information to the NRC or to a licensee of the NRC. Specificaliy, as discussed below in more detail, the NRC concludes that: 1) Mr. Wicks deliberately failed to send an employee's thermoluminescent dosimeter (TLD) in for immediate processing after he learned of a radiography incident that occurred on July 31,1993 , a violation of 10 CFR $34.33(d)$; 2) Mr. Wicks deliberately failed to perform an evaluation of the same employee's radiation exposure after becoming aware of the incident, a violation of 10 CFR 20.201; 3) Mr. Wicks deliberately provided inaccurate information to NRC investigators about the July 31, 1993, incident and his follow-up to the incident, a violation of 10 CFR 30.10; and 4) During March, Apri1, and July of 1993 and January 1994, Mr. Wicks deliberately failed to ensure that calibrated alarm ratemeters were provided and used by WIX radiography personnel, a violation of 10 CFR $34.33(f)(4)$.

The first three violations above are directly related to the July 31,1993 , radiography incident. That incident, which was reported to Mr. Wicks on the 
date it occurred, by the two WIX employees who were involved in it, involved a radiation source in a radiographic exposure device not being properly returned to its shielded position before the device was moved by one of the employees. This resulted in the self-reading pocket dosimeter of one of the employees, a radiographer's assistant, going off-scale, indicating that the radiographer's assistant received a radiation exposure beyond the range of the pocket dosimeter.' When the pocket dosimeter of someone engaged in radiography is discharged beyond its normal range, NRC regulations in 10 CFR Parts 34 and 20, respectively, require: 1) that the licensee send the individual's TLD in for immediate processing to determine the individual's radiation exposure; and 2) that the licensee perform evaluations as necessary, whether or not a TLD reading is available, to determine the individual's radiation exposure and to ensure compliance with NRC exposure limits. In this case, the NRC concludes that Mr. Wicks deliberately did neither and that he has not been truthful in providing information about this incident to NRC personnel and others.

When the NRC began its investigation of this incident in January 1994, Mr. Wicks had no record of the radiographer's assistant's exposure for the day or month in question. Mr. Wicks stated during the investigation and at the enforcement conference that after learning of the incident he sent all TLDs worn by company personnel during the month of July 1993 in one package to Landauer, Inc., the company that processes TLDs for WIX, and that he included a note requesting immediate processing of the TLD worn by the radiographer's assistant. However, a representative of Landauer, Inc., stated to NRC

1 Later reenactments of the incident resulted in an estimate that the radiographer's assistant received 6 rems, an exposure in excess of the NRC occupational quarterly limit of 3 rems in effect at the time of the incident. 
personnel that while it had received TLDs from WIX for other employees for the month of July 1993, it had no record of receiving a TLD for the radiographer's assistant for that month and no record of receiving a request from Mr. Wicks for expedited processing of any TLDs sent in for that month. In fact, exposure records for the month of July 1993 and quarterly records for the months of JuTy-September 1993 which were mailed by Landauer to WIX and retained by WIX contain no information regarding the radiographer's assistant's exposure for the month of July 1993 (her exposure records for all other months are available). ${ }^{2}$

Mr. Wicks told NRC investigators that he had never provided an exposure estimate to the radiographer's assistant because he had none to give her, i.e., he did not have a report from Landauer. However, this is inconsistent with statements by: 1) the radiographer's assistant that she persisted in trying to obtain from Mr. Wicks her exposure for the month of July and that Mr. Wicks eventually -- about three weeks after the incident -- told her she had received 350 millirem, 2) the radiographer involved in the incident that Mr. Wicks had informed him that "everything was OK" and that the radiographer's assistant had received 600 millirem for the quarter, and 3) the assistant's husband, al so a WIX employee, that Mr. Wicks had called his wife two to three weeks after the incident and had given her a number "which was lower and we were happy."

${ }^{2}$ Mr. Wicks claims that he was unaware of this fact until the NRC questioned him in January 1994. 
Mr. Wicks contended during the enforcement conference that he had been misled by the employees involved in the incident into believing that the incident was not serious. While both employees admit to providing Mr. Wicks false accounts of the incident in an attempt to cover up their own mistakes, the radiographer's assistant and her husband both told NRC investigators that Mr. Wicks was informed when the reports were turned in on July 31, 1993, that the reports were false and that Mr. Wicks was told that the radiographer involved in the incident had been asleep in the truck instead of supervising the radiographer's assistant (as required by NRC regulations). Mr. Wicks denied having been told that the reports were false.

Mr. Wicks also told NRC personnel during the enforcenent conference that he did not realize that Landauer had not provided him a July 1993 exposure record for the radiographer's assistant and had not called Landauer until the NRC began its investigation in January 1994. The only explanation Mr. Wicks has offered for not pursuing the question of the radiographer's assistant's July 1993 exposure is that he was very busy. However, the following events raise significant questions about Mr. Wicks' credibility:

1. In August 1993, Mr. Wicks received Landauer's report for the month of July 1993 which, as indicated earlier, contained no monthly exposure record for the radiographer's assistant. Despite, according to $\mathrm{Mr}$. Wicks, having requested immediate processing of the assistant's badge from Landauer, Mr. Wicks told the NRC investigator that he didn't read the monthly report. 
2. Mr. Wicks stated at the enforcement conference that he placed the assistant on limited duty as soon as he was informed of the incident pending the receipt of a report from Landauer and that she was limited to working in the darkroom and "completely away from my shooting area" from July 31, 1993, until she left WIX toward the end of September 1993. ${ }^{3}$ Mr. Wicks stated that having an employee in a restricted status for nearly two months did not remind him of the fact that he had never received a response to his request for immediate processing of her July 1993 TLD.

3. On October 1, 1993, Mr. Wicks provided a summary of the radiographer's assistant's radiation exposure history, including the period in question (July 1993), to her new employer, an NRC licensee. In doing so, Mr. Wicks relied not on Landauer records, even though records were available for all months but July and September 1993, but by adding up daily dosimeter records, which were blank for July 31, 1993. Despite making these calculations for the radiographer's assistant, Mr. Wicks stated at the enforcement conference that he was not reminded of the fact that he had never received a response to his request for immediate processing of her July 1993 TLD.

4. Later in October 1993, Mr. Wicks responded to a request from the NRC for the radiation exposure reports of terminated employees, as required by

3 The NRC notes that the radiographer's assistant disputes Mr. Wicks' account, stating that she was permitted to resume work involving exposure to radiation about three weeks after the incident when Mr. Wicks called her and told her that her exposure was 350 millirems. 
10 CFR 20.408(b). In responding to this request, Mr. Wicks did not provide a report for the radiographer's assistant despite having provided one for her husband, whose termination date occurred five days after hers. Mr. Wicks had not provided the NRC a termination report for the radiographer's assistant when the NRC began its investigation in January 1994.

Moreover. Mr. Wicks is an experienced radiographer and has been trained on the significance of overexposures. Considering that this appears to be the first time that his firm had the potential for an overexposure warranting immediate processing of the assistant's badge and assuming that the badge was sent as he states, then it is not credible that he would not have followed up on it. The NRC also does not consider credible Mr. Wicks' statement that he sent the TLD in for processing. According to Landauer, the incidence of TLDs being lost in delivery is very small. In this case, the loss of the radiographer's assistant's TLD in the mail is not an issue because Mr. Wicks has indicated on a number of occasions that he packaged all WIX TLDs together for shipment to Landauer and Landauer received the package. Landauer representatives have informed the NRC staff that all TLDs are electronically scanned upon receipt, and that Landauer employs the use of a data base to verify that TLDs which are scanned after processing match those which are scanned upon receipt. The process is designed to alert Landauer to situations in which a TLD is lost during processing. Landauer's automated reporting system includes controls to flag any TLD number which was scanned upon receipt and was not scanned again after processing. Lost TLDs are noted on dosimetry reports provided to Landauer customers. 
Based on its review of the evidence gathered during its investigation, as well as the information obtained during the enforcement conference, the NRC concludes that Mr. Wicks did not send the radiographer's assistant's TLD in for processing; that Mr. Wicks deliberately failed to conduct an evaluation of this individual's radiation exposure from the incident; and that Mr. Wicks deliberately provided false information regarding the incident to the NRC and false information regarding the individual's radiation exposure history to another licensee of the NRC.

In addition, with regard to the NRC's requirement that all radiography personnel be equipped with alarm ratemeters that have been calibrated at periods not to exceed one year, the NRC's investigations found that Mr. Wicks repeatedly failed to ensure that this requirement was met. This violation was first discovered and discussed with Mr. Wicks following an inspection and investigation in April 1993. When the NRC conducted its investigation beginning in January 1994, this same violation was found to have occurred in July 1993, two months after it was first discussed with Mr. Wicks, and again in January 1994 when Mr. Wicks could not produce current calibration records for alarm ratemeters worn by either of two radiography personnel on January 18, 1994. When questioned by NRC investigators, Mr. Wicks provided conflicting statements as to whether he had even supplied ratemeters to his radiographers but he said he understood it was his responsibility to ensure that alarm ratemeters were calibrated. Given the repetitive nature of this violation and Mr. Wicks' knowledge of this requirement, the NRC concludes that Mr. Wicks deliberately caused the licensee to violate this requirement. 
Based on the above, the NRC staff concludes that Larry D. Wicks, President and Radiation Safety office for WIX, has engaged in deliberate misconduct that has caused the Licensee to be in violation of 10 CFR $34.33(d), 34.33(f)(4)$, and 20.201. It further appears that Mr. Wicks has deliberately provided to NRC personnel and to another licensee of the NRC information that he knew to be incomplete or inaccurate in some respect material to the NRC, in violation of 10 CFR 30.10. The NRC must be able to rely on the Licensee and its employees to comply with NRC requirements, including the requirement to provide information that is complete and accurate in all material respects. Mr. Wicks' actions in causing the Licensee to be in deliberate violation of radiation safety requirements and his misrepresentations to the NRC have raised serious doubts as to whether he can be relied upon to comply with NRC requirements and to provide complete and accurate information to the NRC. NRC confidence in Mr. Wicks' conducting NRC-licensed activities safely and in compliance with NRC requirements is further eroded by the fact that he was the President of the company and the Radiation Safety Officer when he engaged in deliberate misconduct. In both of these positions, particularly in his role as the Radiation Safety Officer, Mr. Wicks is relied upon by the NRC to ensure that all radiation safety requirements are met. Conduct of this nature cannot and will not be tolerated by the NRC.

Consequently, I lack the requisite reasonable assurance that licensed activities can be conducted in compliance with the Commission's requirements and that the health and safety of the public will be protected, if Mr. Wicks 
were permitted at this time to engage in NRC-licensed activities. Therefore, the public health, safety and interest require that Larry $D$. Wicks be prohibited from engaging in NRC-licensed activities (including any supervising, training, or auditing) for either an NRC licensee or an Agreement State licensee performing licensed activities in areas of NRC jurisdiction in accordance with 10 CFR 150.20 for a period of five (5) years from the date of this Order. Furthermore, pursuant to 10 CFR 2.202, I find that the significance of the violations and conduct described above is such that the public health, safety and interest require that this order be immediately effective.

Accordingly, pursuant to sections $81,161 \mathrm{~b}, 161 \mathrm{i}, 182$ and 186 of the Atomic Energy Act of 1954, as amended, and the Commission's regulations in 10 CFR 2.202 and 10 CFR 30.10 , IT IS HEREBY ORDERED, EFFECTIVE IMMEDIATELY, THAT:

1. Larry Dale Wicks is prohibited for five years from the date of this Order from engaging in NRC-licensed activities, except as provided in item 3, below. NRC-licensed activities are those activities that are conducted pursuant to a specific or general license issued by the NRC, including but not limited to, those activities of Agreement State licensees conducted pursuant to the authority by 10 CFR 150.20. 
2. The first time Mr. Wicks is employed in NRC-licensed activities following the five-year prohibition, he shall notify the Director, Office of Enforcement, U.S. Nuclear Regulatory Commission, Washington, D. C. 20555 and the Regional Administrator, NRC Region IV, at least five days prior to the performance of licensed activities (as described in 1 above). The notice shall include the name, address, and telephone number of the NRC or Agreement State licensee and the location where the licensed activities will be performed. The notice shall be accompanied by a statement that $\mathrm{Mr}$. Wicks is committed to compliance with regulatory requirements and the basis why the commission should have confidence that he will now comply with applicable NRC requirements.

3. Mr. Wicks is permitted to conduct licensed activities only as necessary to maintain licensed material in the possession of Western Industrial $X$-Ray Inspection Company in safe storage and transfer the material to an authorized recipient.

The Director, Office of Enforcement, may, in writing, relax or rescind any of the above conditions upon demonstration by Mr. Wicks of good cause.

V

In accordance with 10 CFR 2.202, Mr. Wicks must, and any other person adversely affected by this Order may, submit an answer to this Order, and may request a hearing on this Order, within 20 days of the date of this Order. The answer may consent to this Order. Uniess the answer consents to this 
Order, the answer shall, in writing and under oath or affirmation, specifically admit or deny each allegation or charge made in this order and shall set forth the matters of fact and law on which Mr. Wicks or other person adversely affected relies and the reasons as to why the order should not have been issued. Any answer or request for a hearing shall be submitted to the Secretary, U.S. Nuclear Regulatory Commission, Attn: Chief, Docketing and Service Section, Washington, DC 20555. Copies also shall be sent to the Director, Office of Enforcement, U.S. Nuclear Regulatory Commission, Washington, DC 20555, to the Assistant General Counsel for Hearings and Enforcement at the same address, to the Regional Administrator, NRC Region IV, 611 Ryan Plaza Drive, Suite 400, Arlington, Texas 76011, and to Mr. Wicks if the answer or hearing request is by a person other than Mr. Wicks. If a person other than Mr. Wicks requests a hearing, that person shall set forth with particularity the manner in which his or her interest is adversely affected by this Order and shall address the criteria set forth in 10 CFR $2.714(d)$.

If a hearing is requested by Mr. Wicks or a person whose interest is adversely affected, the Commission will issue an Order designating the time and place of any hearing. If a hearing is held, the issue to be considered at such hearing shall be whether this order should be sustained.

Pursuant to 10 CFR $2.202(\mathrm{c})(2)(1)$, Mr. Wicks, or any other person adversely affected by this Order, may, in addition to demanding a hearing, at the time the answer is filed or sooner, move the presiding officer to set aside the immediate effectiveness of the Order on the ground that the Order, including 
the need for immediate effectiveness, is not based on adequate evidence but on mere suspicion, unfounded allegations, or error.

In the absence of any request for hearing, the provisions specified in Section IV above shall be final 20 days from the date of this Order without further order or proceedings. AN ANSWER OR A REQUEST FOR HEARING SHALL NOT STAY THE IMMEDIATE EFFECTIVENESS OF THIS ORDER.

FOR THE NUCLEAR REGULATORY COMMISSION

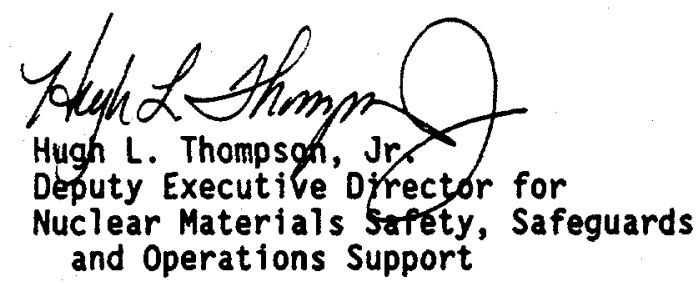

Dated at Rockville, Maryl and this 2 theday of September 1994 
On January 27. 1994, the Nuclear Regulatory Comission, Region IV. Office of Investigations, initiated an investigation to determine whether a radiographer deliberately allowed a radiographer's assistant to work without supervision and whether the licensee deliberately failed to evaluate a potential overexposure incident. During the conduct of the investigation. it was alleged a false report regarding the potential overexposure was deliberately submitted to the licensee by the radiographer and the radiographer's assistant. During the conduct of this investigation. there were additional allegations that the licensee had deliberately failed to provide calibrated alarm ratemeters to radiographers and the licensee's radiographers had deliberately failed to supervise radiographer's assistants.

Evidence developed during the investigation substantiated the allegation that a radiographer del iberately al lowed a radiographer's assistant to perform radiographic operations without proper supervision, and the licensee deliberately did not conduct an evaluation of a potential overexposure incident. Additionally, this investigation determined that a radiographer and a radiographer's assistant deliberately prepared and submitted false reports about the potential overexposure incident to the licensee. This investigation further determined that on January 18, 1994. the I censee deliberately failed to provide calibrated al arm ratemeters to a radiographer and radiographer's assistant. This investigation deterained that in a separate incident from that previously addressed. there was insufficient evidence to establish that the licensee's radfographers had deliberately falled to supervise radiographer's assistants whtle conducting radiographic operations. 
In the course of the teleconference, we became satisfied:

- WIX has an adequate reason for selecting Mr. Heath as Radiation Safety officer. Though he is not a trained RSO, he has an engineering degree and radiography background and will be required to take appropriate training. Paragraph 5 of the settlement Agreement provides further assurance by requiring audits of operations. The staff is satisfied with this arrangement. Tr. 17-19.

- Mr. John Phillips, who has a $1 / 3$ financial interest in the company and is the company lawyer and a local municipal court judge, will take management responsibility. Mr. Larry Wicks will be restricted to a role in sales and business acquisition and as an advisor to Mr. Phillips about commercial practices in the industry. Mr. Wicks will not play any role in employee evaluation. Tr. 20-25, 29-30, 30-32.

Although Mr. Wicks may be reinstated in WIX after two years upon application to the staff, this process will not be automatic and will entail staff discretion. Tr. $25-29,32-33,34$. 
1 . ORDER

For all the foregoing reasons and upon consideration of the entire record in this matter, it is this 15th day of November, 1995, ORDERED, that:

1. The Western Industrial $\mathrm{x}$-Ray Inspection Co., Inc. (WIX) motions to withdraw its requests for hearing are granted. The withdrawn requests for hearing relate to (a) the Staff's Order to WIX of June 16, 1994 ("Order Suspending License (Effective Immediately) and Demand for Information," 59 Fed. Reg. 33027 (June 27, 1994) ("Suspension Order"), dated July 1, 1994, and (b) the staff's orders to WIX of September 27, 1994 ("Order to Transfer Material (Effective Immediately) and order Revoking Iicense" 59 Fed. Reg. 50931 (October 6, 1994) ("Revocation order"), dated october 14, 1994 .

2. WIX is dismissed as a party in the proceedings pertaining to those orders and to this proceeding.

3. The motion of Larry for hearing on the staff's?

aks to withdraws his request to Mr. Wicks of september 27, 1994 ("Order Prohibiting Involvement in NRC-Licensed Activities (Effective Immediately)," 59 Fed. Reg. 50932 (October 6, 1994) ("Prohibition Order"), dated October 14, 1994, is granted.

4. Mr. Wicks is dismissed as a party in the proceeding pertaining to that order. 
5. The "stipulation for settlement of proceedings," contained in Attachment $A$ to this Memorandum and order is adopted as an order of this Atomic safety and Licensing Board.

THE ATOMIC SAFETY AND LICENSING BOARD
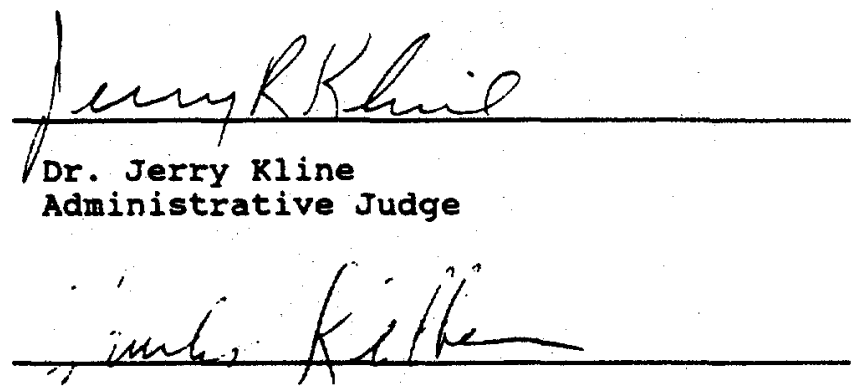

Dr. Charles Kelber Administrative Judge

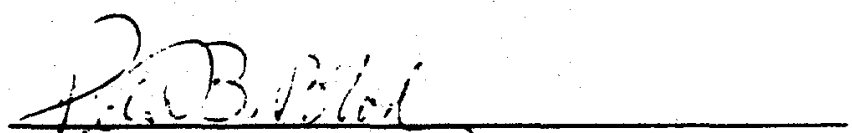

Peter B. Bloch

Chairman

Rockville, Maryland 
$11 / 2 / 95$

\section{Attachment $\mathbf{A}^{1}$}

\section{STIPULATION FOR SETTLEMENT OF PROCEEDINGS ${ }^{2}$}

THIS AGREEMENT is made by and between Western Industrial X-Ray Inspection Co., Inc. "WIX" or the Licensee"), Larry D. Wicks ("Wicks") and the staff of the United states Nuclear Regulatory Commission ("NRC staff" or "staff"), to wit:

WHEREAS WIX holds Byproduct Material License No. 49-27356-01 issued by the NRC pursuant to 10 C.F.R. Parts 30 and 34, which license authorizes WIX to possess sealed sources of iridium-192 in various radiography devices for use in performing industrial radiography activities in accordance with the conditions specified therein, and is due to expire on August 31,1996 ; and

The heading contained in the stipulation of the parties has been omitted as redundant. Page numbers have been changed for consistency with this document.

In the course of the Teleconference of November 3 , the Board admitted two exhibits. Tr. 16. On further consideration, it is not necessary that those exhibits be admitted. This Attachment is sufficient. Accordingly, the two Board exhibits shall not be admitted. This order and its attachment may be read in conjunction with the official Transcript. No further exhibits are necessary. 
WHEREAS wicks is and has been at all times relevant hereto the principal shareholder, President, and Radiation safety officer ("RSO") of WIX, with responsibilities, inter alia, involving compliance with NRC requirements for radiation protection; and

WHEREAS on June 16, 1994, the NRC Staff issued an "Order Suspending License (Effective Immediately) and Demand for Information," 59 Fed. Reg. 33027 (June 27, 1994) ("Suspension Order"), based, inter alia, upon a finding that WIX had engaged in numerous violations of NRC radiation safety regulatory requirements, including several violations which were found to be of a recurring nature and/or were committed deliberately by Licensee employees, including WIX's President and RSO, in violation of 10 C.F.R. $\$ 30.10 ;$ and

WHEREAS the Suspension Order suspended License No. 49-27356-01, pending further order, effective immediately, and also demanded information from the Licensee in order to assist the NRC in determining whether the license should be revoked and whether wicks should be prohibited from performing NRC-licensed activities; and

WHEREAS on September 27, 1994, the NRC staff issued (1) further orders directed to wIX, "order to Transfer Material (Effective Immediately) and order Revoking License" 59 Fed. Reg. 50931 (October 6, 1994) ("Revocation order"); and (2) an order directed to wicks, "order Prohibiting Involvement in NRC-Licensed Activities (Effective Immedi- 
ately)," 59 Fed. Reg. 50932 (October 6, 1994) ("Prohibition order"), based, inter alia, upon a finding that the NRC lacked adequate assurance that the public health and safety would be protected if wIX retains possession of licensed material, or if licensed activities are conducted by WIX and/or its President and RSO in the future; and WHEREAS the Revocation order required the Licensee, inter alia, to transfer all NRC-regulated material in its possession to the manufacturer or other person authorized to possess the material and revoked License No. 49-27356-01, effective immediately; and

WHEREAS the Prohibition Order, inter alia, prohibited wicks from engaging in NRC-licensed activities (including any supervising, training or auditing) for either an NRC licensee or Agreement state licensee performing licensed activities in areas of NRC jurisdiction in accordance with 10 C.F.R. S 150.20 for a period of five (5) years from the date of that order; and

WHEREAS requests for hearing were filed by WIX concerning the suspension order and Revocation order on July 1 and October 14, 1994, respectively, and a request for hearing was filed by wicks concerning the Prohibition order on October 14, 1994, in response to which adjudicatory proceedings have been convened and remain pending before an Atomic Safety and Licensing Board ("Licensing Board") at this time; and 
WHEREAS the undersigned parties recognize that certain advantages and benefits may be obtained by each of them through settlement and compromise of the matters now pending in litigation between them, including, without limitation, the elimination of further litigation expenses, uncertainty and delay, and other tangible and intangible benefits, which the parties recognize and believe to be in the public interest; and

WHEREAS, pursuant to 10 C.F.R. S 2.203, the Staff, WIX and wicks have stipulated and agreed to the following provisions for settlement of the abovercaptioned proceedings, subject to the approval of the Licensing Board, before the taking of any testimony or trial or adjudication of any issue of fact or law; and

WhEREAS WIX and wicks are willing to waive their hearing and appeal rights regarding these matters, in consideration of the terms and provisions of this stipulation and settlement agreement; and

WHEREAS the terms and provisions of this Stipulation, once approved by the Licensing Board, shall be incorporated by reference into an order, to be issued in accordance with subsections $b, I$ and 0 of section 161 of the Atomic Energy Act of 1954, as amended (the "Act"), 42 U.S.C. 52201 , and into License No. 49-27356-01, issued pursuant to section 81 of the Act, 42 U.s.C. S 2111, and shall be subject to 
enforcement pursuant to the Commission's regulations and Chapter 18 of the Act, 42 U.S.C. $\$ 2271$ et seg.; NOW, THEREFORE, IT IS STIPULATED AND AGREED AS FOLLOWS :

1. Wicks agrees to refrain from engaging in, and is hereby prohibited from engaging in, any NRC-licensed activities up to and including June 15, 1999, five years from the date of the NRC "Order suspending License (Effective Immediately)," dated June 16, 1994. For purposes of this stipulation and Agreement, the definition of "NRC-licensed activities," as set forth above, is understood to include any and all activities that are conducted pursuant to a specific license issued by the NRC or general license conferred by NRC regulations, including, but not limited to, those activities of Agreement state licensees conducted pursuant to the authority granted by 10 C.F.R. S 150.20, but does not include marketing, other business activities or ownership of an interest in WIX.

2. For a period of five years after the abovespecified five-year period of prohibition has expired, i.e., from June 16, 1999 through June 15, 2004, Wicks shall, within 20 days of his acceptance of each and any employment offer involving NRC-licensed activities or his becoming involved in NRC-licensed activities, as defined above, provide written notice to the Regional Administrator, NRC Region IV, 611 Ryan Plaza Drive, Suite 400, Arlington, $\mathbf{T X} 76011$, of the name, 
address, and telephone number of the employer or the entity where he is, or will be, involved in the NRC-licensed activities, and a detailed description of his duties and the activities in which he is to be involved.

3. In the first notification provided pursuant to Paragraph 2 above, wicks shall include a statement of his commitment to compliance with NRC regulatory requirements and an explanation of the basis why the Commission should have confidence that he will comply with applicable NRC requirements.

4. Notwithstanding the above, it is understood that wicks may request reconsideration of the prohibition order after WIX has conducted two (2) years of resumed NRClicensed activities, however, it is understood that the NRC staff shall have the sole discretion to determine whether any such reconsideration is warranted, with respect to which determination wicks hereby waives any right to or opportunity for hearing or appeal before the NRC and/or a court of law.

5. It is hereby agreed by the parties that WIX shall be allowed to resume its conduct of NRC-licensed activities upon approval of this stipulation and Agreement by the Licensing Board, but it is expressly understood and agreed that wicks is prohibited from participation in the conduct of any such activities in accordance with Paragraph 1 above. In furtherance of this understanding, WIX and Wicks further agree that License No. 49-27356-01 shall be modified 
to include the following requirements, prior to any resumption of NRC-licensed activities, which shall remain in effect up to and including June 15, 1999 or until such other time as may be explicitly stated herein:

(a) WIX (1) shall retain Mr. Ray Heath, or other person approved by the NRC staff to serve as RSO or successor Rso until at least June 15 , 1999, who shall at all times be responsible for performing the duties of an RSO and shall be responsible for maintenance of all NRC-required records; (2) shall establish the minimum number of hours to be devoted to RSo duties; and (3) shall describe the responsibilities and audits to be performed by the Rso under the radiation safety program. WIX shall submit the qualifications of any person it proposes to serve as RSo, other than Mr. Heath, to the NRC staff for prior approval; the statement of qualifications should demonstrate that the person has not previously been employed by WIX, that he/she is likely to exercise independence from wicks, and that he/she meets the NRC's minimum criteria established for an RSO.

(b) Prior to restart, Mr. Heath (if he is selected by wIX to serve as RSO). must successfully complete an Industrial Radiography course 
of at least 40 hours duration. Within six months of restart, Mr. Heath must successfully complete a Radiography Radiation safety officer training course of at least three days duration. Courses selected by the licensee to satisfy this condition must receive prior approval by NRC Region IV.

(c) If Mr. Heath is selected to serve as RSO, WIX shall name an Assistant Radiation Safety officer to the license. The designated Assistant RSO must have at least five years experience as an industrial radiographer. The assistant Rso shall be readily available to respond to incidents and emergencies and shall be on call by means of a pager, telephone, or radio at all times when radiographic operations are scheduled or in progress.

(d) If Mr. Heath is selected to serve as RSO, the RSO and Assistant RSO shall be identified by name on the 1icense. An Assistant RSO shall be carried on the license until Mr. Heath has gained the appropriate practical radiography training and experience, or a minimum of one year.

(e) The Rso shall have full authority for radiation protection and safety, entirely inde- 
pendent from any involvement or interference by wicks, with full authority to direct all aspects of radiography operations including the authority to shut down operations that are unsafe or which violate the license or NRC requirements. The RSO shall report to the person who is retained pursuant to paragraph $5(g)$ below, and the RSo shall have the authority to report any concerns directly to the NRC. The RSO shall notify the NRC immediately if wicks participates or becomes involved in any NRC-licensed activities, or interferes with the RSO's independence in any way.

(f) The RSO shall certify to the NRC staff in advance of commencing NRC-licensed activities that he/she understands (1) the terms of this Stipulation and Agreement, the license requirements, and the commission's regulations associated with radiography, (2) that he/she may be held personally accountable for violations of the 1 icense or Commission requirements under 10 C.F.R. S 30.10 for deliberate misconduct, (3) that he/she is responsible for making reports required by NRC regulations, and (4) that wicks is prohibited from having any involvement in NRC-licensed activities, and that the RSO is 
required to notify the NRC immediately if wicks participates or becomes involved in any NRClicensed activities, or interferes with the RSO's independence in any way.

(g) WIX will retain the services of a person, to be approved in advance by the NRC staff, to be responsible for management of those aspects of the company's business that could affect the RSO or the conduct of radiation safetyrelated activities, including the authority (1) to hire and terminate the employment of the RSO or other employees engaged in the conduct of NRC-licensed activities, (2) to make and execute salary and other financial decisions which may affect such persons including the RSo, and/or the safe conduct of NRC-licensed activities, and (3) to have control over financial resources (e.g., through the establishment of an escrow account) sufficient to ensure the safe and proper conduct of NRC-licensed activities. This individual shall also notify the NRC immediately if he/she determines that wicks is or has been involved in NRC-licensed activities.

(h) Neither wicks nor any person related to, or in privity with, him shall have any direct or indirect involvement in or exercise control over 
NRC-licensed activities, including management, supervision and financial control or participation in hiring and firing decisions which may affect the RSO and/or the safe and proper conduct of NRC-licensed activities. In addition, while Beverly Wicks (Wicks' wife) may continue to serve as WIX' secretary, she shall not participate in or have any involvement in NRC-Iicensed activities (including, without limitation, such tasks as mailing and receiving film badges or radiation exposure reports, handing or distributing dosimeters, and any other tasks related to radiation safety).

(I) WIX shall retain an outside independent auditor (and any successor auditor), who is to be approved in advance by the NRC staff based upon a review of the auditor's qualifications. The auditor (and any approved successor) shall submit an audit plan for NRC approval that describes the items to be audited and the methodology to be employed, including the number of field inspections and the percentage of employees engaged in radiography who will be audited in the field. The auditor is to provide copies of all draft and final audit reports to the NRC staff at the same time that such reports are 
provided to WIX. WIX shall provide a written response to the audit findings within 30 days after receipt thereof, including a description of any corrective actions taken or an explanation of why such actions were not taken. The auditor shall perform audits and examinations of the radiation safety program and operations, including the performance of field audits, as follows: An independent program audit will be performed at about three months, and no later than six months, following the resumption by WIX of NRC-licensed activities, with the results of the audit submitted to NRC Region IV for review. Following the initial audit, audits will be performed every six months. One year after restart, the NRC RIV Regional Administrator may consider, at the request of the licensee, relief in the audit requirements based on good cause shown. Further, the timing and scope of such audits shall not be disclosed to wIX or wicks in advance; and the auditor shall be informed in advance that Wicks is prohibited from participation in any NRC-licensed activities.

(j) Any notification required to be made pursuant to this Paragraph 5 shall be made in writing to the Regional Administrator, NRC Re- 
gion IV, 611 Ryan Plaza Drive, Suite 400, Arlington, $\mathrm{TX} 76011$.

(k) The Regional Administrator, NRC Region IV, may relax or rescind any of the conditions set forth in this stipulation and Agreement upon a demonstration of good cause, however, it is understood that the Regional Administrator shall have the sole discretion to determine whether any such reconsideration is warranted, with respect to which determination WIX and wicks hereby waive any right to or opportunity for hearing or appeal before the NRC and/or a court of law.

6. The parties agree that, as an integral part of this stipulation and upon execution hereof, and subject to the approval of this stipulation by the Licensing Board, (a) WIX and wicks will withdraw their July 1 and October 14, 1994 requests for hearing on the suspension order, Revocation order and Prohibition Order, and (b) the parties will file a joint request for dismissal of the proceedings on the suspension Order, Revocation order and Prohibition order, with prejudice, it being understood and agreed that this stipulation and Agreement resolves all outstanding issues with respect to those orders, that WIX and wicks hereby waive their hearing and appeal rights regarding the matters which are the subject of these orders, and that the staff will take 
no further enforcement or other action against WIX or Wicks in connection with those orders, subject to the terms of this Stipulation and Agreement.

7. WIX and wicks hereby agree that a failure on their part to comply with the terms of this stipulation and Agreement will constitute a material breach of this Agreement, and that any such breach may result in the immediate revocation or suspension of the license, effective immediately, if the NRC staff, in its sole discretion, determines such action to be appropriate, and may result in further enforcement or other action as the NRC staff may be determine, in its sole discretion, to be appropriate.

8. It is understood and agreed that nothing contained in this Stipulation and Agreement shall relieve the Licensee from complying with all applicable NRC regulations and requirements. Further, it is understood and agreed that nothing contained in this Agreement shall be deemed to prohibit the NRC staff from taking enforcement or other action (a) against any entity or person for violation of this Stipulation and Agreement, or (b) against persons other than WIX or wicks in connection with or related to any of the matters addressed in the Suspension Order, Revocation order or Prohibition order, should the staff determine, in its sole discretion, that it is appropriate to do so.

9. It is understood and agreed that this stipulation and Agreement is contingent upon prior approval by the 
Licensing Board and dismissal of the instant adjudicatory proceedings.

10. This Stipulation and Agreement shall be binding upon the heirs, legal representatives, successors and assigns of the parties hereto.

IN WITNESS WHEREOF, we set our hand and seal this 2nd day of November, $1995 .^{3}$

FOR WESTERN INDUSTRIAL $X$-RAY INSPECTION CO., INC., and LARRY D. WICKS :

Lazry D. Wicks, individually and as president, Western Industrial $X$-Ray Inspection Co.. Inc.

John $c$. Phillips

Counsel for Western Industrial

$X$-Ray inspection Co., Inc.

and Larry D. Wieks
FOR THE NRC STAFF:

Sherwin E. Turk

Counsel for NRC staff

${ }^{3}$ The signed original was filed with the Board. 
In the matter of

Lany D. MICKs

(EVANSTOW, WrowIns)

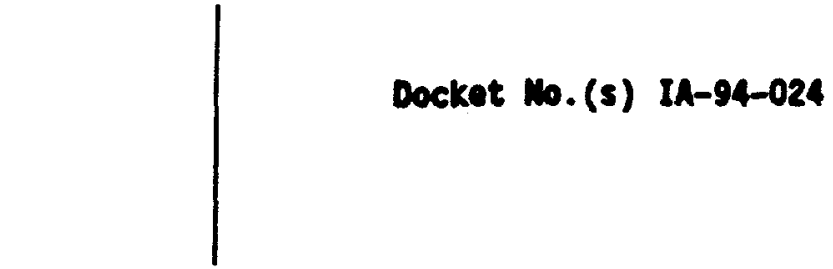

CERTIFICATE OF SERVICE

I hareby cortify that coples of the forogoing FINL IMITIAL ORDER-LBP-95-22 have been served upon the following persons by U.S. mall, fIrst class, except as otherwise noted and in accordance with the requireants of 10 CFR Sec. 2.712 .

Office of Comission Appellate Adjudication

U.S. Nuclear Regulatory Comission Washington, DC 20555

Adninistrative Judge

Jerry R. Kline

Atonic Safety and Licensing Board Mall Stop T-3 F 23

U.S. Nuclear Regulatory Comission Mashington, DC 20555

Office of the General Counsel

Mail Stop 0-15 18

U.S. Muclear Regulatory Comission

Washington, DC 20555

Dated at Rockville, Md. this

16 day of November 1995
Adninistrative Judge

Poter 8. Bloch, Chairman

Atonic Safety and Licensing Board

Mail Stop T-3 F 23

U.S. Nuclear Regulatory Comission

Uashington, DC 20555

Adainistrative Judge

Charles $N$. Kelber

Atcuic Safoty and Licensing Board

Mall stop T-3 F 23

U.S. Muclear Regulatory Comission Mashington, DC 20555

John C. Phillips, Esq.

Counsel for Larry $D$. Wicks

Phillips Law offices

912 Main Street

Evanston, Ir 82931

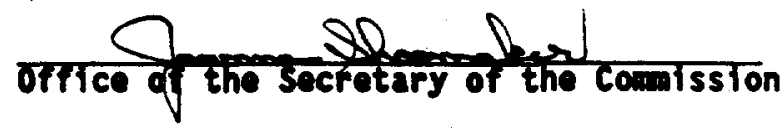




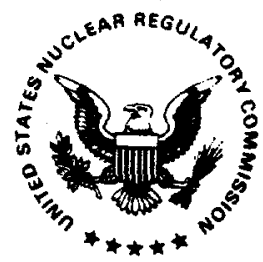

\section{UNITED STATES \\ NUCLEAR REGULATORY COMMISSION \\ WASHINGTON, D.C. 20555-0001}

June 27,1995

\section{IA $95-022$}

Marc W. Zuverink

[HOME ADDRESS DELETED

UNDER 10 CFR 2.790]

\section{SUBJECT: ORDER PROHIBITING INVOLVEMENT IN NRC-LICENSED ACTIVITIES AND} REQUIRING CERTAIN NOTIFICATION TO NRC (0I REPORT NO. 3-94-061)

Dear Mr. Zuverink:

The enclosed Order is being issued as a result of an investigation by the NRC office of Investigations (OI) which found that you stole NRC-1icensed material, hydrogen-3 (tritium), from the facility of Cammenga Associates, Holland, Michigan, and that you gave the material to members of the public. In doing so, you deliberately acquired, possessed, and transferred NRClicensed material without an NRC license and neediessly exposed members of the public to radiation. The violation is fully described in the enclosed order.

The Order prohibits your involvement in NRC-1icensed activities for a period of ten years from the date of the order. In addition, for a period of five years after the ten year prohibition period, the order also requires you to notify the NRC within 20 days of your employment or involvement in licensed activities. Pursuant to Section 223 of the Atomic Energy Act of 1954, as amended, any person who willfully violates, attempts to violate, or conspires to violate, any provision of this order is subject to criminal prosecution as set forth in that section.

You are required to respond to this Order and should follow the instructions specified in Section VI of the Order when preparing your response. Questions concerning this Order should be addressed to James Lieberman, Director, Office of Enforcement, who can be reached at telephone number (301) 415-2741.

In accordance with 10 CFR 2.790 of the NRC's "Rules of Practice," a copy of this letter, with your address removed, and the enclosure will be placed in the NRC Pubiic Document Room (PDR). To the extent possible, your response should not include any personal privacy information or proprietary information so that it can be placed in the PDR without redaction. However, if you find it necessary to include such information, you should clearly indicate the specific information that you desire not be placed in the PDR, and provide the legal basis to support your request for withholding the information from the public. 
The responses directed by this letter and the enclosed order are not subject to the clearance procedures of the Office of Management and Budget as required by the Paperwork Reduction Action of 1980, Public Law No. 96-511.

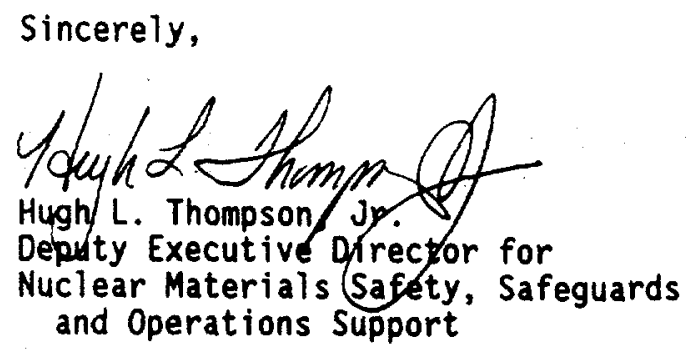

Docket No. 030-33009

License No. 21-26460-01

Enclosure:

Order Prohibiting Involvement in NRC Licensed Activities

cc w/enclosure:

Edith A. Landman

Assistant U.S. Attorney

Michael P. McDonald

Attorney for Mr. Zuverink

Cammenga Associates, Inc. 
UNITED STATES

NUCLEAR REGULATORY COMMISSION

In the Matter of

MARC $W$. ZUVERINK

Holl and, Michigan
\{

IA 95-022

ORDER PROHIBITING INVOLVEMENT IN NRC-LICENSED ACTIVITIES AND REQUIRING CERTAIN NOTIFICATION TO NRC

Cammenga Associates, Inc. (Cammenga or Licensee) holds Byproduct Material License No. 21-26460-01 issued by the U. S. Nuclear Regulatory Commission (NRC or Commission) pursuant to 10. CFR Part 30 on September 27, 1993. The license authorizes the use of byproduct material, hydrogen-3 (tritium), in sealed vials for the production of tritium radioluminescent devices. The license is due to expire on January 31, 1998. From July 29, 1994, to September 16, 1994 , Marc W. Zuverink was contracted to Cammenga through a temporary hiring service.

The Licensee trained Mr. Zuverink as a radiation worker. The training included a discussion of potential sanctions against employees who misused, mishandled, or stole radioactive material. Mr. Zuverink's answers on a comprehensive written exam given by the Licensee indicate that he was aware of potential civil and criminal penalties for employees who deliberately violate federal regulations or license requirements governing the use of tritium. The radiation safety training allowed Mr. Zuverink to enter the Licensee's restricted area and to have access to licensed material as part of the process 
of manufacturing tritium illuminated compasses under contract to the United States military.

On September 30, 1994, the Licensee undertook an inventory of NRC-licensed material in its possession. Upon completion, the inventory determined that 1099 vials, containing a total of 49.11 curies of tritium, were missing. The Licensee notified the NRC and the Ottawa County, Michigan, Sheriff's Department. An inspection was conducted by NRC Region III personnel on October 7 and 8, 1994, to evaluate the radiological consequences of the missing material and to monitor the retrieval of the tritium sources. Investigations were conducted by the NRC Office of Investigations (OI), the Ottawa County Sheriff's Department, and the Department of Defense Criminal Investigation Service.

Mr. Zuverink admitted to the investigators that he took tritium vials and completed compasses with tritium inserts from the Licensee on more than one occasion. The largest theft apparently took place on September 10, 1994, when he took nine bags of vials from the Licensee, each bag containing 100 vials of tritium, 50 millicuries per vial. Mr. Zuverink stated that he gave the tritium vials and compasses to various members of the public, including approximately 100 vials (5,000 millicuries) to a teenage skateboarder whom he did not know. Mr. Zuverink also admitted that he crushed a tritium vial on a kitchen table at his home in the presence of another individual. This action contaminated the tabletop and caused the other individual to receive a minor 
tritium uptake (internal tritium contamination). Minor contamination of a countertop and tables was also found in a restaurant where Mr. Zuverink had given ane or more vials to another member of the public. Mr. Zuverink was able to arrange for the return of 548 tritium vials, leaving 551 vials unaccounted for ( 401 vials at 50 millicuries, 57 vials at 25 millicuries, and 93 vials at 5 millicuries).

OI also found that Mr. Zuverink made false statements to an 0 I investigator and an NRC inspector during an interview on October 7, 1994. During that interview, Mr. Zuverink stated that he never had any tritium vials at his home, had given tritium vials to only two individuals, and had stolen only one compass. These statements were contradicted by Mr. Zuverink's sworn testimony on October 17, 1994.

Mr. Zuverink's acquisition, possession and transfer of NRC-1icensed material, tritium, is a deliberate violation of 10 CFR 30.3, "Activities requiring license." 10 CFR 30.3 requires that no person shall manufacture, produce, transfer, receive, acquire, own, possess, or use byproduct material except as authorized in a specific or general license. Mr. Zuverink was not authorized in a specific or general license to acquire, possess or transfer byproduct material, including tritium.

Pursuant to a plea arrangement dated February 3, 1995, Mr. Zuverink agreed to plead guilty in the U. S. District Court for the Western District of Michigan to one criminal count of violating 18 U.S.C. 641, a misdemeanor. Specifically, the agreement describes the charge as stealing compasses, 
containing the radioactive substance tritium, which belonged to the United States and which were manufactured under contract for the United States. As a result, on April 18, 1995, a judgment was entered whereby Mr. Zuverink was sentenced to serve one year in federal custody, pay a fine of $\$ 500$, make restitution to Cammenga in the amount of $\$ 1,000$, and pay a $\$ 25$ special assessment to the court.

Based on the above, the NRC concludes that Marc W. Zuverink engaged in deliberate misconduct that constituted a violation of 10 CFR 30.3 when he stole and transferred NRC-licensed material. The NRC must be able to rely on its licensees, and the employees of licensees and licensee contractors, to comply with NRC requirements, including the requirement that licensed material cannot be acquired, possessed or distributed without a specific or general license. The deliberate violation of 10 CFR 30.3 by Marc $W$. Zuverink, as discussed above, has raised serious doubt as to whether he can be relied on to comply with NRC requirements.

Consequently, I lack the requisite assurance that Marc W. Zuverink will conduct licensed activities in compliance with the Commission's requirements or that the health and safety of the public will be protected if Marc $W$. Zuverink were permitted at this time to be involved in NRC-licensed activities. Therefore, the public health, safety and interest require that for a period of ten years from the date of this Order, Marc W. Zuverink be prohibited from any involvement in NRC-licensed activities for either: (1) an 
NRC licensee, or (2) an Agreement State licensee performing licensed activities in areas of NRC jurisdiction in accordance with 10 CFR 150.20. In addition; for a period of five years commencing after the ten year period of prohibition, Mr. Zuverink must notify the NRC of his employment or involvement in NRC-1icensed activities to ensure that the NRC can monitor the status of Mr. Zuverink's compliance with the Commission's requirements and his understanding of his commitment to compliance.

\section{V}

Accordingly, pursuant to sections $81,161 \mathrm{~b}, 161 \mathrm{i}, 182$, and 186 of the Atomic Energy Act of 1954, as amended, and the Commission's regulations in 10 CFR 2.202, 10 CFR Part 30, and 10 CFR 150.20, IT IS HEREBY ORDERED THAT:

1. Marc W. Zuverink is prohibited for a period of ten years from the date of this Order from engaging in NRC-licensed activities. NRC-licensed activities are those activities that are conducted pursuant to a specific or general license issued by the NRC, including, but not limited to, those activities of Agreement State licensees conducted pursuant to the authority granted by 10 CFR 150.20 .

2. For a period of five years, after the above ten year period of prohibition has expired, Marc $W$. Zuverink shall, within 20 days of his acceptance of each employment offer involving NRC-1icensed activities or his becoming involved in NRC-licensed activities, as defined in Paragraph V.1 above, provide notice to the Director, Office of 
Enforcement, U. S. Nuclear Regulatory Commission, Washington, DC 20555, of the name, address, and telephone number of the employer or the entity where he is, or will be, involved in the NRC-licensed activities. In the first such notification, Marc W. Zuverink shall include a statement of his comitment to compliance with regulatory requirements and the basis as to why the Commission should have confidence that he will now comply with applicable NRC requirements.

The Director, Office of Enforcement, may, in writing, relax or rescind any of the above conditions upon demonstration by Mr. Zuverink of good cause.

\section{VI}

In accordance with 10 CFR 2.202, Marc W. Zuverink must, and any other person adversely affected by this Order may, submit an answer to this Order, and may request a hearing on this Order, within 45 days of the date of this Order. The answer may consent to this Order. Unless the answer consents to this Order, the answer shall, in writing and under oath or affirmation, specifically admit or deny each allegation or charge made in this Order and shall set forth the matters of fact and law on which Mr. Zuverink or other person adversely affected relies and the reasons as to why the Order should not have been issued. Any answer or request for a hearing shall be submitted to the Secretary, U. S. Nuclear Regulatory Commission, Attn: Chief, Docketing and Service Section, Washington DC 20555. Copies also shall be sent to the Director, Office of Enforcement, U. S. Nuclear Regulatory Commission, Washington, DC 20055, and to the Regional Administrator, NRC Region III, 801 
Enforcement, U. S. Nuclear Regulatory Commission, Washington, DC 20555, of the name, address, and telephone number of the employer or the entity where he is, or will be, involved in the NRC-licensed activities. In the first such notification, Marc W. Zuverink shall include a statement of his commitment to compliance with regulatory requirements and the basis as to why the Commission should have confidence that he will now comply with applicable NRC requirements.

The Director, Office of Enforcement, may, in writing, relax or rescind any of the above conditions upon demonstration by Mr. Zuverink of good cause.

In accordance with 10 CFR 2.202, Marc W. Zuverink must, and any other person adversely affected by this Order may, submit an answer to this Order, and may request a hearing on this Order, within 45 days of the date of this Order. The answer may consent to this Order. Unless the answer consents to this Order, the answer shall, in writing and under oath or affirmation, specifically admit or deny each allegation or charge made in this Order and shall set forth the matters of fact and law on which Mr. Zuverink or other person adversely affected relies and the reasons as to why the Order should not have been issued. Any answer or request for a hearing shall be submitted to the Secretary, U. S. Nuclear Regulatory Commission, Attn: Chief, Docketing and Service Section, Washington DC 20555. Copies also shall be sent to the Director, Office of Enforcement, U. S. Nuclear Regulatory Comission, Washington, DC 20055, and to the Regional Administrator, NRC Region III, 
801 Warrenville Road, Lisle, Illinois 60632-4531, if the answer or hearing request is by a person other than Mr. Zuverink. If a person other than Mr. Zuverink requests a hearing, that person shall set forth with particularity the manner in which his or her interest is adversely affected by the Order and shall address the criteria set forth in 10 CFR 2.714(d).

If a hearing is requested by Mr. Zuverink or a person whose interest is adversely affected, the Commission will issue an Order designating the time and place of any hearing. If a hearing is held, the issue to be considered at such hearing shall be whether this Order should be sustained. Since Mr. Zuverink is currently in Federal custody, if a hearing is requested, the Commission will not act on the hearing request until Mr. Zuverink is released from Federal custody. If Mr. Zuverink requests a hearing, the hearing request will not be granted unless Mr. Zuverink: (1) notifies the Secretary, U.S. Nuclear Regulatory Commission, at the address given above, within 20 days of his release from Federal custody, that he has been released from Federal custody; and (2) provides in the notice his then-current address where he can be contacted and a statement that he continues to desire the hearing. A copy of the notice shall also be sent to the Director, Office of Enforcement, and the Assistant General Counsel for Hearings and Enforcement, at the address given above.

In the absence of any request for hearing, the provisions specified in Section $\checkmark$ above shall be effective and final 45 days from the date of this Order without further order or proceedings. In the event that Mr. Zuverink makes the sole request for a hearing and fails to comply with the notification 
$-8-$

requirements above, the provisions specified in Section $V$ above shall be effective and final 20 days after he is released from Federal custody.

FOR THE NUCLEAR REGULATORY COMMISSION

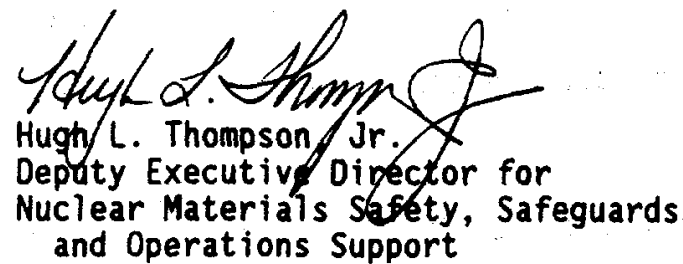

Dated at Rockville, Maryl and thisenthay June 1995 

B- NOTICES OF VIOLATION

NUREG-0940, PART I 



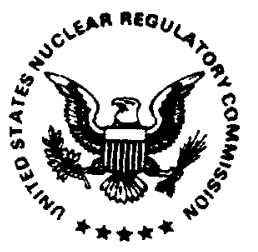

IA $96-065$

Mr. Robert C. Allen

[HOME ADDRESS DELETED

UNDER 10 CFR 2.790]
UNTED STATES

NUCLEAR REGULATORY COMMISSION

REGION II

101 MARIETTA STREET, N.W., SUITE 2000

ATLANTA, GEORGIA $30323-0150$

October 18, 1996

SUBJECT: NOTICE OF VIOLATION

(NRC Inspection Repart Nos. 50-280, 281/95-20 and Office of Investigations Report No. 2-95-029)

Dear Mr. Allen:

This letter refers to an inspection conducted on September 14 through October 4. 1995, as well as an NRC Office of Investigations (OI) investigation completed on June 28. 1996. During these reviews, the NRC examined the facts and circumstances surrounding your conduct of licensed activities at Virginia Electric and Power Company's (VEPCO) Surry Power Station on September 13. 1995. You were informed of our initial findings and provided copies of the applicable inspection report and synopsis of the OI investigation report by letter of August 16, 1996. You were also provided an opportunity to respond in writing to the apparent violation or request a predecisional enforcement conference to discuss the apparent violation, the root cause. and the corrective actions to preclude recurrence. By letter dated August 29, 1996. you requested a conference. A closed. transcribed conference was conducted on October 2. 1996. at the Region II office in Atlanta. Georgia. A list of conference attendees and a copy of NRC presentation materials are enclosed.

Based on the information developed during the inspection and investigation as well as the information that you provided during the conference. the NRC has determined that your actions on September 13. 1995. constituted a violation of your NRC Senior Reactor Operator's license. Specifically, your license required that you observe the operating procedures of the Surry Power Station: however. on September 13, 1995. you deliberately did not adhere to plant procedures for the venting of the Unit 1 pressurizer relief tank (PRT). On this date. you were the Supervisor of Shift Operations providing oversight of control room shift operations. After becoming aware that the reactor coolant system pressure was higher than that which would permit performance of certain outage-related critical path activities, you instructed operations personnel to establish a second vent path for the PRT, contrary to plant procedures.

without first obtaining the proper approval to do so (i.e. . a Procedure Action Request). In particular, you were knowledgeable of the procedural

requirements, yet you deliberately allowed the venting to proceed knowing that valve No. 1-RC-HCV-1549 was not closed and a polyethylene hose was not connected from valve No. 1-RC-ICV-5025, as required. This resulted in simultaneous vent paths, one of which bypassed the process vent system causing an unmonitored. ground-ievel release. In addition, you fajled to obtain the proper release permit for the ground-level release. The NRC concluded.

however. that your failure in this regard was inadvertent. You were cognizant of the radiological and industrial safety implications of the release when it 
was initiated. through review of the PRT elevated release permit and discussion with shift health physics supervision.

1

During the conference, you admitted that you were aware of the valve position and polyethylene hose requirements: however. you indicated that the failure to obtain the proper gaseous release permit was unintentional. You attributed the violation to a serious error in judgement resulting from self-imposed pressure to maintain the outage schedule and an extremely heavy workload of outage activities. You further stated that you intended to formally request a change to the procedure to allow the procedure deviations. but did not, and that the violation was not premeditated or conducted with the intent to avoid compliance. As a result of these actions you received substantial disciplinary action. including termination of your NRC license on December 28. 1995. at VEPCO's request. In addition. you were required to participate in a performance remediation plan.

As an NRC-7icensed senior reactor operator, the NRC conferred upon you its confidence that you would assure that the Surry Power Station would be operated safely and in accordance with al.1 regulatory requirements. In addition, the NRC places a high value on the standards set by plant management for the conduct of plant operations. As the Supervisor of Shift Operations on September 13. 1995, you were in a position to direct and coordinate the activities of other operations personnel. Your actions did not adhere to these standards and also undermined the trust inherent in your position to ensure public health and safety. In addition to violating your NRC license. your actions were contrary to the provisions of 10 CFR 50.5. Deliberate Misconduct. and VEPCO was subject to escalated enforcement as a result of your actions. A copy of this enforcement action was provided to you in our August 16. 1996 letter.

Given the significance of your actions, after consultation with the Director. Office of Enforcement. and the Deputy Executive Director for Nuclear Reactor Regulation. Regional Operations. and Research. the NRC has decided to issue the enciosed Notice of Violation (Notice) to you based on your deliberate violation of plant operating procedures. In accordance with the "Genera1 Statement of Policy and Procedures for NRC Enforcement Actions" (Enforcement Policy), NUREG-1600, the violation has been classified at Severity Level III.

In determining the sanction against you. the NRC gave considerable weight to the fact that you fully cooperated with NRC's investigation. showed remorse and accepted full responsibility for your errors, and were placed in a performance remediation program by VEPCO. However, should there be evidence of similar conduct on your part in the future, you may be subject to further enforcement action that could possibly include an order prohibiting your involvement in NRC-licensed activities for up to five years.

You are required to respond to this letter and should follow the instructions specified in the enclosed Notice when preparing your response. In your response, you should document the specific actions taken and any additional actions you plan to prevent recurrence. 
In accordance with Section 2.790 of the NRC's "Rules of Practice." Part 2. Title 10. Code of Federal Regulations. records or documents compiled for enforcement purposes are placed in the NRC Public Document Room (PDR). A copy of this letter. With your address removed. and your response will be placed in the PDR. To the extent possible. your response should not include any personal privacy. proprietary. or safeguards information so that it can be placed in the POR without redaction. Also. a copy of this enforcement action will also be provided to the licensee.

Questions concerning this Notice may be addressed to Mr. Thomas Peebles. Chief. Operator Licensing Branch at 404-331-5541.

Docket No. 55-6236

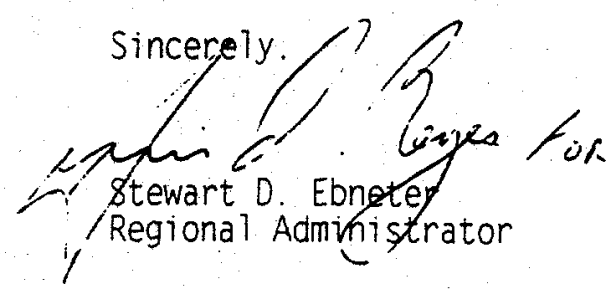

License No. SOP-4301-4

CERTIFIED MAIL NO. P 343386352

RETURN RECEIPT REQUESTED

$$
\begin{array}{ll}
\text { Enclosures: } & \text { 1. Notice of Violation } \\
& \text { 2. Conference Attendees } \\
& \text { 3. NRC Presentation Materials }
\end{array}
$$

CC w/enclosures [HOME ADDRESS CELETED]:

David A. Christian. Manager.

Surry Power Station

Virginia Electric and Power Company

5570 Hog Is land Road

Surry. VA 23883 
NOTICE OF VIOLATION

Mr. Robert C. Allen

[HOME ADDRESS DELETED

UNDER 10 CFR 2.790]

Docket No. $55-6236$

License No. SOP-4301-4

IA $96-065$

During an NRC inspection conducted on September 14 through October 4. 1995. and an NRC Office of Investigations investigation completed on June 28. 1996. a violation of NRC requirements was identified. In accordance with the "General Statement of Policy and Procedures for NRC Enforcement Actions." NUREG-1600. the violation is listed below:

Senior Reactor Operator's License. SOP-4301-4. Docket No. 55-6236 (expired on December 28, 1995) required that you comply with al1 applicable rules, regulations, and orders of the Commission.

Surry Nuclear. Power Station Technical Specification 6.4 required that detailed written procedures be provided for activities which would have an effect on nuclear safety and that those procedures be followed.

Procedure 1-OP-RC-011. Pressurizer Relief Tank Operations, Revision 1. Section 5.5. established the methods for venting the Pressurizer Relief Tank (PRT). Steps 5.5 .5 and 5.5 .6 required that a polyethylene hose be connected from Valve No. I-RC-ICV-5025 to the nearest containment purge exnaust duct and Valve No. 1-RC-HCV-1549. PRT Vent. be closed. respectively

Contrary to the above. on September 13. 1995. Mr. Robert C. Allen deliberately failed to comply with the provisions of his senior reactor operator license issued by the NRC. Specifically. Mr. Allen

dei iberately violated approved. detailed written procedures for the venting of the Unit 1 pressurizer relief tank in that:

1. A polyethylene hose was not connected from Valve No. I-RC-ICV-5025 to the nearest containment purge exhaust duct: and

2. Vaive No. 1-RC-HCV-1549. PRT Vent. was not closed. (01013)

This is a Severity Level III violation (Supplement VII).

Pursuant to the provisions of 10 CFR 2.201. Mr. Robert C. Allen is hereby required to submit a written statement or explanation to the $U$. $S$. Nuclear Regulatory Commission. ATTN: Document Control Desk. Washington. D. C. 20555 with a copy to the Regional Administrator. NRC Region II. 101 Marietta Street. Suite 2900. At lanta. Georgia 30323. within 30 days of the date of the letter transmitting this Notice of Violation (Notice). The reply should be clearly marked as a "Reply to Notice of Violation" and should include for each violation: (1) the reason for the violation. or. if contested. the basis for disputing the violation. (2) the corrective steps that have been taken and the results achieved. (3) the corrective steps that will be taken to avoid further violations, and (4) the date when full compliance will be achieved. Your

Enclosure 1 
response may reference or include previous ly docketed correspondence. if the correspondence adequately addresses the required response. If an adequate reply is not received within the time specified in this Notice. an order or a Demand for Information may be issued as to why such other action as may be proper should not be taken. Where good cause is shown. consideration will be given to extending the response time.

Under the authority of Section 182 of the Act. 42 U.S.C. 2232, this response sha11 be submitted under oath or affirmation.

Because your response will be placed in the NRC Public Document Room (PDR), to the extent possible. it should not include any personal privacy. proprietary. or safeguards information so that it can be placed in the PDR without

redaction. However. If you find it necessary to include such information. you should clearly indicate the specific information that you desire not to be placed in the PDR. and provide the legal basis to support your request for withholding the information from the public.

Dated at Atlanta. Georgia

this 18th day of October 1996 


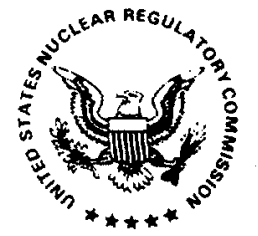

\author{
UNITED STATES \\ NUCLEAR REGULATORY COMMISSION \\ REGION III \\ 801 WARRENVILLE ROAD \\ LISLE. ILLINOIS 60532-4351
}

September 5, 1996

IA $96-050$

Mr. Steven R. Allent

[HOME ADDRESS DELETED

UNDER 10 CFR 2.790]

SUBJECT: NOTICE OF VIOLATION

(NRC OFFICE OF INVESTIGATIONS REPORT NO. 3-95-043)

Dear Mr. Allent:

This refers to an NRC Office of Investigations (OI) Report of Investigation No. 3-95-043 concerning the circumstances surrounding your violation of NRC requirements while working for NSS Numanco, as a laundry/decontamination technician at the Point Beach Nuclear Plant. A copy of the synopsis of the investigation is enclosed.

On or about Apri1 6, 1995, you were processing protective clothing through a laundry radiation monitor when an al arm was received. You subsequently located a radioactively contaminated particle in the clothing, cut it out, and as a prank, taped it to the underside of a table in the laundry room where massi ins and respirators were normally surveyed. Later you told a health physics technician about the prank and the particle was removed for proper disposal.

Deliberate misconduct is defined in 10 CFR 50.5, (a copy is enclosed) and includes an intentional act or omission that causes a licensee to be in violation of any NRC rule or NRC license condition. The NRC OI investigation determined that your actions, consisting of improperly disposing of the radioactively contaminated particle by taping it to the underside of the survey table rather than disposing of it in accordance with the licensee's procedures and exposing your coworkers to the particle, was done deliberately and placed the licensee for Point Beach Nuclear Plant, Wisconsin Electric Power Company, in violation of NRC license conditions and NRC regulations. As a result, you violated 10 CFR 50.5 by causing the licensee to be in violation of License Conditions 2.E of Operating License NoS. DPR-24 and DPR-27 and 10 CFR $30.34(\mathrm{c})$. Your misconduct also created the potential for additional and unnecessary exposure because your actions caused workers to perform needless decontamination activities.

You should be aware of the seriousness with which the NRC views your actions. The public health, safety, and trust demand that nuclear power plant personnel conduct themselves with integrity at all times. You did not conduct yourself in this manner in this case. Given the significance of your actions, I have decided, after consultation with the Director, Office of Enforcement and the Deputy Executive Director for Nuclear Reactor Regulation, Regional Operations 
and Research, to issue to you the enclosed Notice of Violation (Notice) for violation of 10 CFR 50.5, while you were engaged in licensed activities at the Point Beach Nuclear Plant.

You are required to respond to this letter and should follow the instructions specified in the enclosed Notice when preparing your response. Your response should document the specific actions taken and any additional actions you plan to prevent recurrence. In addition, your conduct raises a question as to whether NRC should issue you an order prohibiting your future involvement in licensed activities. Therefore, pursuant to 10 CFR 2.204, you should provide your reasons as to why the NRC should have confidence that you will comply with NRC regulatory requirements in the future. After reviewing your response to this Notice, including your proposed corrective actions and the results of future inspections, the NRC will determine whether further NRC enforcement action is necessary to ensure your compliance with NRC regulatory requirements.

You should be aware that any similar conduct on your part in the future could result in more significant enforcement action against you, including an order removing you from NRC-licensed activities or subjecting you to criminal sanctions.

In accordance with Section 2.790 of the NRC's "Rules of Practice, "Part 2, Title 10, Code of Federal Regulations, records or documents compiled for enforcement purposes are placed in the NRC Public Document Room (PDR). A copy of this letter with your address removed, and your response, will be placed in the PDR after 45 days unless you provide sufficient basis to withdraw this letter and Notice of Violation. To the extent possible, your response should not include any personal privacy, proprietary, or safeguards information so that it can be placed in the PDR without redaction.

If you have any questions or comments, please contact Bruce Burgess of my staff at (708) 829-9666.

Sincerely,

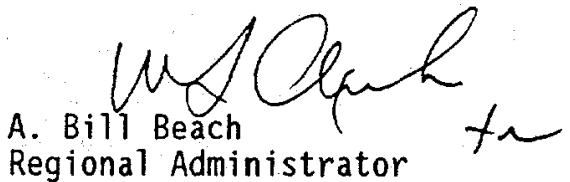

Enclosures:

1. Notice of Violation

2. Synopsis of OI Report No. 3-95-043

3. Deliberate Misconduct Rule, 10 CFR 50.5

CC: (if placed in the PDR)

Robert Link, Vice President - Nuciear Power

NUREG-0940, PART I B-7 
During an NRC investigation conducted by the NRC Office of Investigations (OI Report No. 3-95-043), a violation of NRC requirements was identified. In accordance with the "General Statement of Policy and Procedure for NRC Enforcement Actions," NUREG-1600, the violation is set forth below:

10 CFR 30.34 (c) provides, in part, that the 1 icensee will confine its possession and use of byproduct material to the locations and purposes authorized by the license.

License Condition 2.E authorizes the 1 icensee, pursuant to the Act and 10 CFR Parts 30 and 70 , to possess byproduct and special nuclear materials as may be produced by the operation of the facility, but not to separate such materials retained within the fuel cladding.

Point Beach Nuclear Plant Procedure HP 2.15, Revision 2, "Control of Personnel Exposure to High Level Contamination, Hot Particles, and Activated or Fission Product Debris," Step 4.6, requires, in part, that high levels of contamination detected on protective clothing shall be removed and handled in a manner which minimizes personnel exposure.

10 CFR 50.5 provides, in part, that any employee of a contractor who engages in deliberate misconduct that causes a licensee to be in violation of any rule, regulation, or order, or any term condition, or limitation of any license, issued by the Commission may be subject to enforcement action in accordance with 10 CFR Part 2, Subpart B.

Contrary to the above, on or about April 6, 1995, Mr. Allent, while working as a contractor laundry technician/decontaminator at Point Beach Nuclear Plant, engaged in deliberate misconduct by taping a radioactively contaminated particle to the underside of a table in the radiological laundry room, a use of byproduct material not authorized by License Conditions 2.E and not in accordance with Point Beach Nuclear Plant Procedure HP 2.15. (01013)

This is a Severity Level III violation (Supplement I).

Pursuant to the provisions of 10 CFR 2.201, Mr. Allent is hereby required to submit a written statement or explanation to the U.S. Nuclear Regulatory Commission, ATTN: Document Control Desk, Washington, D.C. 20555 with a copy to the Regional Administrator, Region III, within 30 days of the date of the letter transmitting this Notice of Violation (Notice). This reply should be clearly marked as a "Reply to a Notice of Violation" and should include for each violation: (1) the reason for the violation, or, if contested, the basis for disputing the violation, (2) the corrective steps that have been taken and the results achieved, (3) the corrective steps that will be taken to avoid further violations, and (4) the date when full compliance will be achieved. Your response may reference or include previous docketed correspondence, if the correspondence adequately addresses the required response. If an adequate reply is not received within the time specified in this Notice, an order or a Demand for Information may be issued as to why such other action as may be 
proper should not be taken. Where good cause is shown, consideration will be given to extending the response time. Under the authority of Section 182 of the Act, 42 U.S.C. 2232, this response shall be submitted under oath or affirmation.

Your response will be placed in the NRC Public Document Room (PDR) unless you provide sufficient basis to withdraw this Notice. To the extent possible, your response should not include any personal privacy, proprietary, or safeguards information so that it can be placed in the PDR without redaction. However, if you find it necessary to include such information, you should clearly indicate the specific information that you desire not to be placed in the PDR, and provide the legal basis to support your request for withholding the information from the public.

Dated at Lisle, Illinois

this 5 th day of September 1996 
This investigation was initiated by the Nuclear Regulatory Commission (NRC), Office of Investigations (OI), Region III (RIII), on October 30, 1995, to determine if a contract employee of NSS NUMANCO (NSS) employed at the Point Beach Nuclear Plant (Point Beach), Two Rivers, Wisconsin, had deliberately exposed his coworkers to radiation from a contaminated particle, as a result of a prank by the contract employee. The investigation was also to determine if the licensee, Wisconsin Electric Power Company (WE), deliberately failed to control the radioactive material, i.e., the contaminated particle and engaged in a cover up of the incident by failing to initiate a Condition Report on the matter. Further, the alleger claimed being discriminated against for bringing to NSS and WE management information regarding the contaminated particle incident.

Eased on the evidence developed during the investigation, it is concluded that a NSS contractor deliberately exposed his coworkers to a radioactively contaminated particle in violation of NRC License Conditions and regulations.

The investigation also determined that there was no regulatory requirement to initiate a Condition Report on the incident of misuse of radioactive material by the contract employee.

Further, based on the evidence developed during the investigation, it is concluded that there is insufficient evidence to substantiate the alleged employment discrimination against the NSS contract employee. 
Section 50.5 neliberate misconduct.

(a) Any licensee or any employee of a licensee; and any contractor (including a supplier or consultant), subcontractor, or any employee of a contractor or subcontractor, of any licensee, who knowingly provides to any licensee, contractor, or subcontractor, components, equipment, materials, or other goods or services, that relate to a licensee's activities subject to this part; may not:

(1) Engage in deliberate misconduct that causes or, but for detection, would have caused, a licensee to be in violation of any rule, regulation, or order, or any term, condition, or limitation of any license, issued by the commission, or

(2) Deliberately submit to the NRC, a licensee, or a licensee's contractor or subcontractor, information that the person submitting the information knows to be incomplete or inaccurate in some respect material to the NRC.

(b) A person who violates paragraph (a)(1) or (a) (2) of this section may be subject to enforcement action in accordance with the procedures in 10 CFR part 2 , subpart $B$.

(c) For purposes of paragraph (a) (1) of this section, deliberate misconduct by a person means an intentional act or omission that the person knows:

(1) Would cause a licensee to be in violation of any rule, regulation, or order, or any term, condition, or limitation, of any license issued by the commission, or

(2) Constitutes a violation of a requirement, procedure, instruction, contract, purchase order or policy of a licensee, contractor, or subcontractor.

[56 FR 40690, Aug. 15, 1991] 


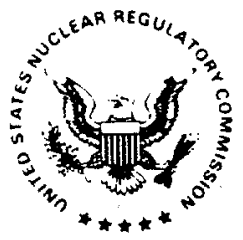

UNITED STATES

NUCLEAR REGULATORY COMMISSION

REGION IV

611 RYAN PLAZA DRIVE, SUITE 400

ARLINGTON, TEXAS 76011.8064

October 17,1995

IA $95-042$

Richard L. Balcom

[HOME ADDRESS DELETED

PURSUANT TO 10 CFR 2.790]

SUBJECT: NOTICE OF VIOLATION

(PREDECISIONAL ENFORCEMENT CONFERENCE)

(NRC OFFICE OF INSPECTOR GENERAL INVESTIGATION 92-49I)

Dear Mr. Balcom:

This refers to a predecisional enforcement conference conducted between Houston Lighting \& Power Company (HL\&P) and the NRC on June 16, 1995 at the NRC Region IV Office in Arlington, Texas. You participated in this conference. The conference was held to review details concerning the alleged discrimination, in violation of the requirements of 10 CFR 50.7 , by HL\&P against two former members of the licensee's Nuclear Security Department (NSD), Messrs. David Lamb and James Dean. On September 29, 1993, following the issuance of an NRC Office of Inspector General investigation report, the NRC issued a Demand for Information (DFI), requesting that you provide additional information concerning your involvement in May 1992 in terminating the employment of these two South Texas Project (STP) Nuclear Security Department employees. The DFI was issued because it appeared that you had engaged in deliberate misconduct as defined in 10 CFR 50.5 by causing HL\&P to discriminate against these individuals after they had provided safety concerns about STP to the NRC, an activity that is protected by statute. Specifically, Messrs. Lamb and Dean were terminated by HL\&P as a result of your reorganization of the NSD following your appointment to the position of Manager of the Department in January 1992. In addition to the DFI issued to you, the NRC also issued a DFI to HL\&P, requesting similar information.

In your November 15, 1993 response to the DFI, you denied any wrongdoing and stated that you had not discriminated against either individual. In view of the fact that the issues involved in this matter were being actively considered in an ongoing Department of Labor (DOL) hearing before an Administrative Law Judge (ALJ), the NRC considered it appropriate to await the DOL ALJ's decision before resolving the NRC enforcement issue.

On April 6, 1995, the ALJ issued his RDO. The ALJ found that the former NSD employees had been discriminated against by HL\&P in that their employment was terminated on May 4, 1992 in retaliation for having earlier ident ified and reported safety concerns to the NRC. The ALJ also determined that the remedial actions you took to deal with what you perceived as the unsatisfactory conditions within the NSD support the inference that they were causally related to Messrs. Lamb's and Dean's concerns and their persistence in seeking vindication of those concerns. Following the issuance of the ALJ's RDO, the predecisional enforcement conference was conducted on June 16, 1995. 
This conference was transcribed and open to public observation. The purpose of the conference was to give you and HL\&P the opportunity to present your positions regarding your actions connected with the alleged discrimination of the two former NSD employees and to discuss any corrective action that you and HL\&P have taken as a result of the ALJ's findings.

Based upon its evaluation of the findings of the DOL ALJ, the information developed during the OIG investigation, the DFI responses, and the information developed during the predecisional enforcement conference, the NRC has determined that your actions with regard to Messrs. Lamb and Dean violated 10 CFR 50.5 and caused HL\&P to be in violation of 10 CFR 50.7 .

As the then manager of the NSD, you were in a position that conferred upon you trust and confidence in your ability to effectively manage and promote the safe operation of that facility. In that position, you were responsible for the professional treatment of all individuals who bring forward safety concerns. Your actions did not adhere to these standards, and did not provide an appropriate example for those individuals under your supervision, or individuals of HL\&P's organization with which you interfaced. Rather, your actions in this matter created a potential chilling effect towards other station personnel identifying safety concerns.

Given the significance of your actions. I have decided, after consultation with the Commission, to issue to you the enclosed Notice of Violation for your violation of 10 CFR 50.5. The violation has been categorized in accordance with the "General Statement of Policy and Procedure for NRC Enforcement Action" (Enforcement Policy) (60 FR 34381, June 30, 1995) at

Severity Level II. You are required to respond to this letter and the enclosed Notice within 30 days of the date of the final decision by the Secretary of the Department of Labor in 93-ERA-007 and 93-ERA-008, as described in the enclosed Notice of Violation. and should follow the instructions specified in the enclosed Notice when preparing your response. In your response. you should document the specific actions taken and any additional actions you plan to prevent recurrence. Should you contest this violation, the NRC does not intend to resolve any issue in dispute until after the Secretary issues a final decision. In addition, after reviewing your response to this Notice, including your proposed corrective actions, the NRC will determine whether further NRC enforcement action is necessary to ensure compliance with NRC regulatory requirements.

We further note that your employer removed you from licensed activities after issues about possible discrimination arose. The staff has not required that you be removed from NRC regulated activities, and does not currently intend to place any restrictions on your future involvement in licensed activities.

Also enclosed with this letter for your information is a copy of a letter and Notice of Violation and Proposed Imposition of Civil Penalties to HL\&P. 
In accordance with 10 CFR 2.790 of the NRC's "Rules of Practice," enforcement actions are placed in the NRC Public Document Room (POR). A copy of this letter and the enclosed Notice of Violation with your address removed will be placed in the POR.

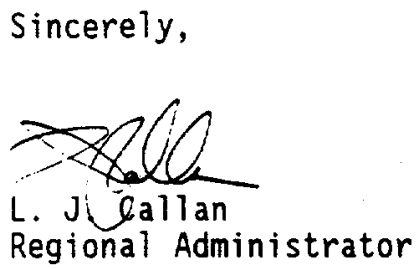

Enclosures: Notice of Violation Letter and Notice of Violation/Proposed CPS to $H L \& P$

cc w/enclosure:

Houston Lighting \& Power Company ATTN: William T. Cottle, Group

Vice President, Nuclear

P.0. Box 289

Wadsworth, Texas 77483

Houston Lighting \& Power Company

ATTN: Lawrence E. Martin, General Manager Nuclear Assurance \& Licensing

P.0. Box 289

Wadsworth, Texas 77483

City of Austin

Electric Utility Department

ATTN: J. C. Lanier/M. B. Lee

721 Barton Springs Road

Austin, Texas 78704

City Public Service Board

ATTN: K. J. Fiedler/M. T. Hardt

P.0. Box 1771

San Antonio, Texas 78296

cc w/encl: See Next Page 
cc w/encl: (Con't)

Morgan, Lewis \& Bockius

ATTN: Jack R. Newman, Esq.

1800 M. Street, N.W.

Washington, D.C. 20036-5869

Central Power and Light Company

ATTN: Mr. C. A. Johnson

P.0. Box 289

Mail Code: N5012

Wadsworth, Texas 77483

INPO

Records Center

700 Galleria Parkway

Atl anta, Georgia 30339-5957

Mr. Joseph M. Hendrie

50 Bellport Lane

Bellport, New York 11713

Bureau of Radiation Control

State of Texas

1100 West 49 th Street

Austin, Texas 78756

Office of the Governor

ATTN: Andy Barrett, Director

P.0. Box 12428

Environmental Policy

Austin, Texas 78711

Judge, Matagorda County

Matagorda County Courthouse

1700 Seventh Street

Bay City, Texas 77414

Licensing Representative

Houston Lighting \& Power Company

Suite 610

Three Metro Center

Bethesda, Maryland 20814

Houston Lighting $\hat{\dot{3}}$ Power Company

ATTN: Rufus S. Scott, Associate General Counsel

P.0. Box 61867

Houston, Texas 77208

cc w/encl: See Next Page 
cc w/encl: (Con't)

Egan \& Associates, P.C.

ATTN: Joseph R. Egan, Esq.

$2300 \mathrm{~N}$ Street, N.W.

Washington, D.C. 20037

Little Harbor Consultants, Inc.

ATTN: Mr. J. W. Beck

44 Nichols Road

Cohasset, MA 02025-1166 
NOTICE OF VIOLATION

$\mathrm{Mr}$. Richard Balcom

IA $95-042$

Houston Lighting \& Power Company

South Texas Project Electric

Electric Generating Station

Based on an NRC investigation conducted May 1992 to February 1993 and a Department of Labor Administrative Law Judge Recommended Decision and Order in DOL Case Nos. 93-ERA-7 and 93-ERA-8 issued on April 6, 1995, a violation was identified. In accordance with the "General Statement of Policy and Procedure for NRC Enforcement Action," (Enforcement Policy) (60 FR 34381, June 30, 1995), the violation is set forth below:

10 CFR 50.5 provides, in part, that any employee of a licensee may not engage in deliberate misconduct that causes a licensee to be in violation of any regulation.

10 CFR 50.7, Employee Protection, prohibits discrimination by a Commission i icensee against any employee for engaging in certain protected activities. Discrimination includes discharge and other actions that relate to compensation, terms, conditions, and privileges of employment. Protected activities are described in Section 210 (now 211) of the Energy Reorganization Act of 1974, as amended, and in general are related to the administration or enforcement of a requirement imposed under the Atomic Energy Act or Energy Reorganization Act.

Contrary to the above, Richard Balcom, a manager above first-line supervision at the Houston Lighting and Power Company's (HL\&P's) Nuclear Security Department (NSD), deliberately discriminated against two employees of HL\&P's NSD. Specifically, Mr. Balcom recommended termination of the employment of Messrs. Lamb and Dean as a result of Messrs. Lamb's and Dean's engaging in protected activities. The protected activities included identifying safety concerns to the NRC. $\mathrm{Mr}$. Balcom's actions resulted in HL\&P's termination of the employment of these individuals, which caused HL\&P to be in violation of 10 CFR 50.7 .

This is a Severity Level II Violation (Supplement VII). (01012)

Pursuant to the provisions of 10 CFR 2.201, you are hereby required to submit a written statement or explanation to the Director, Office of Enforcement, U.S. Nuclear Regulatory Commission within 30 days of the date of the final decision by the Secretary of the Department of Labor in this matter. This reply should be clearly marked as a "Reply to a Notice of Violation" and should include for each alleged violation: (1) the reason for the violation, or, if contested. the basis for disputing the violation, (2) the corrective steps that have been taken and the results achieved, (3) the corrective steps that will be taken to avoid further violations, and (4) the date when full compliance will be achieved. Your response may reference or include previous docketed correspondence, if the correspondence adequately addresses the required response. If an adequate reply is not received within the time 
specified in this Notice, an Order or a Demand for Information may be issued to show cause why such other enforcement action as may be proper should not be taken. Where good cause is shown, consideration will be given to extending the response time.

Under the authority of Section 182 of the Act 42 U.S.C. 2232, this response shall be submitted under oath or affirmation.

Because your response will be placed in the NRC Public Document Room (PDR), to the extent possible, it should not include any personal privacy, proprietary, or safeguards information so that it can be placed in the POR without

redaction. If personal privacy or proprietary information that is not already in the public record is necessary to provide an acceptable response, then please provide a bracketed copy of your response that identifies the information that should be protected and a redacted copy of your response that deletes such information. If you request withholding of such material, you must specifically ident ify the portions of your response that you seek to have withheld and provide in detail the bases for your claim of withholding (e.g., explain why the disclosure of information will create an unwarranted invasion of personal privacy or provide the information required by 10 CFR 2.790 (b) to support a request for withholding confidential commercial or financial

information). If safeguards information is necessary to provide an acceptable response, please provide the level of protection described in 10 CFR 73.21.

Dated at Arlington, Texas

this 17 th day of October, 1995 


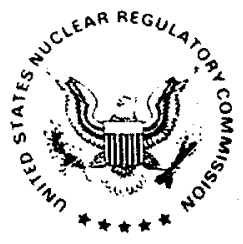

\author{
UNITED STATES \\ NUCLEAR REGULATORY COMMISSION \\ REGION IV \\ 611 RYAN PLAZA DRIVE, SUITE 400 \\ ARLINGTON, TEXAS 76011.8064
}

November 21,1996

IA $96-074$

Mr. Robert Beltran

[HOME AODRESS DELETED

UNDER 10 CFR 2.790]

SUBJECT: NOTICE OF VIOLATION (NRC INVESTIGATION REPORT NO. 4-96-025)

Dear Mr. Beltran:

This refers to an investigation conducted by the NRC's office of

Investigations regarding activities at the Palo Verde Nuclear Generating

Station (Palo Verde). The investigation was conducted to review the

circumstances surrounding apparent false information provided by contract

employees in order to gain unescorted access to the Palo verde facility.

During an NRC inspection conducted in May 1996, a review of security incident records revealed cases where contract employees had falsified background information in order to gain unescorted access to Palo Verde. A subsequent investigation conducted by the NRC (synopsis enclosed) confirmed that prior to being granted temporary unescorted access to Palo verde in October 1995. as an employee of Fluor Daniel. you provided false employment information.

Specifically. your October 1995 application for unescorted access indicated that you had been employed for the previous five years by Mainline Plumbing of Lakewood. California, when in fact. you had never been employed by that company. Records maintained by Arizona Public Service Company (APS) indicate that you again applied for unescorted access in March 1996. admitted at that time that you had previously provided false information, and as a result. were denied access to Palo Verde.

Based upon the NRC's review of the information developed by APS, it appears that you violated the NRC's rule prohibiting deliberate misconduct by providing false information of a material nature to APS. a licensee of the NRC. A copy of the regulation is enclosed. The NRC and its licensees must be able to rely on the integrity and trustworthiness of employees. particularly those who are granted unescorted access to nuclear power plants. Thus. the NRC is issuing you the enclosed Notice of Violation for your actions. In accordance with the "General Statement of Policy and Procedure for NRC Enforcement Actions. "NUREG-1600. the violation in the enclosure has been classified at Severity Level II to reflect the significance of attempting to subvert the access authorization process at Palo Verde. You should be aware the NRC's regulations allow the issuance of civil sanctions to be taken directly against unlicensed persons who. through their deliberate misconduct. cause a licensee to be in violation of NRC requirements. An Order may also be issued to an individual to prevent his or her engaging in licensed activities at all NRC licensed facilities. Future violations of the deliberate misconduct rule, as set forth in 10 CFR 50.5, may also lead to criminal prosecution. 
You are required to respond to this Notice of Violation and should follow the instructions specified in the enclosed Notice, as applicable to your situation. when preparing your response. For example. where the Notice requires you to address your corrective actions. please address what actions you will take to assure compliance in the future should you request to be reemployed in the nuclear industry. The NRC will use your response, in part, to determine whether further enforcement action is necessary to ensure compliance with regulatory requirements should you find employment in NRC-licensed activities in the future.

In accordance with Section 2.790 of the NRC's "Rules of Practice. "Part 2. Title 10. Code of Federal Kegulations. records or documents compiled for enforcement purposes are placed in the NRC Public Document Room (PDR). A copy of this letter and enclosure with your address removed, and your response will be placed in the PDR after 45 days unless you provide sufficient basis to withdraw this letter. A copy also will be sent to APS at that time.

If you have any questions. please contact Gary Sanborn, regional Enforcement officer. at 817-860-8222 or 800-952-9677.

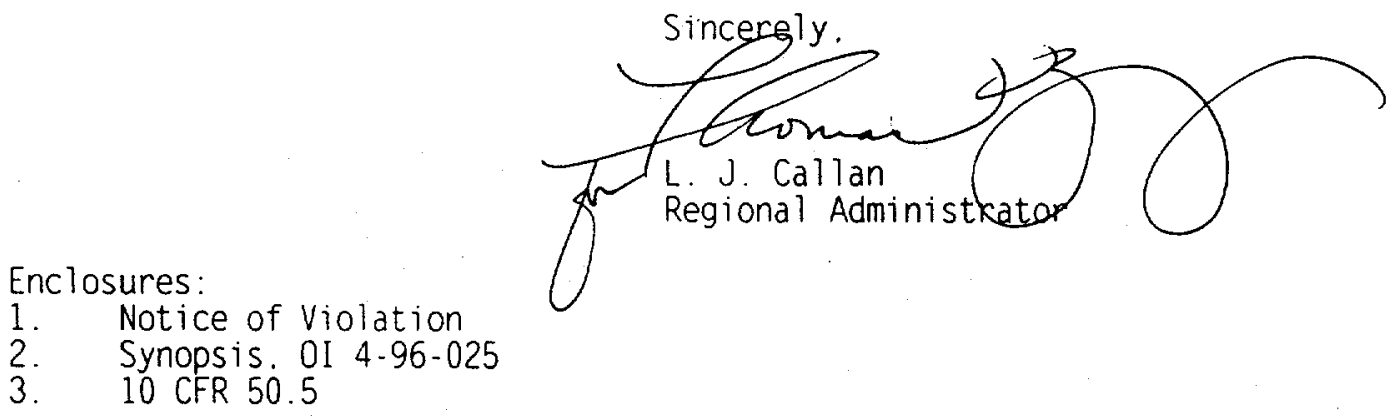


During an NRC investigation completed in September 1996, a violation of NRC requirements was identified. In accordance with the "General Statement of Policy and Procedure for NRC Enforcement Actions," NUREG-1600. the violation is listed below:

10 CFR 50.5 states, in part. that any employee of a contractor of any licensee may not deliberately submit to a licensee information that the person submitting the information knows to be inaccurate in some respect. inaterial to the NRC.

Contrary to the above. prior to being granted temporary unescorted access to the Palo Verde Nuclear Generating Station in October 1995. Robert Beltran submitted information which he knew was inaccurate in some respect material to the NRC. Specifically. Mr. Beltran submitted false employment information. claiming employment with an employer for five years when in fact. he had never been employed by said employer. This information was material to the NRC because employment information is required to be obtained and reviewed by licensees in conducting background investigations of applicants for granting unescorted access to their facilities.

This is a Severity Level III violation (Supplement VII).

Pursuant to the provisions of 10 CFR 2.201. Robert Beltran is hereby required to submit a written statement or explanation to the U.S. Nuclear Regulatory Commission. Regional Administrator. Region IV. 611 Ryan Plaza Drive. Suite 400. Arlington. Texas 76011. within 30 days of the date of the letter transmitting this Notice of violation (Notice). This reply should be clearly marked as a "Reply to a Notice of Violation" and should include for each violation: (1) the reason for the violations, or. if contested. the basis for disputing the violation. (2) the corrective steps that have been taken and the results achieved. (3) the corrective steps that will be taken to avoid further violations, and (4) the date when full compliance will be achieved. Your response may reference or include previous docketed correspondence. if the correspondence adequately addresses the required response. If an adequate reply is not received within the time specified in this Notice. an order or a Demand for Information may be issued as to why such other action as may be proper should not be taken. Where good cause is shown. consideration will be given to extending the response time.

Under the authority of Section 182 of the Act. 42 U.S.C. 2232. this response shall be submitted under oath or affirmation.

Because your response will be placed in the NRC Public Document Room (POR). to the extent possible. it should not include any personal privacy. proprietary. or safeguards information so that it can be placed in the POR without redaction. If personal privacy or proprietary information is necessary to provide an acceptable response, then please provide a bracketed copy of your response that identifies the information that should be protected and a redacted copy of your response that deletes such information. If you request 
withholding of such material. you must specifically identify the portions of your response that you seek to have withheld and provide in detait the bases for your claim of withholding (e.g. . explain why the disclosure of information will create an unwarranted invasion of personal privacy or provide the

information required by 10 CFR 2.790 (b) to support a request for withholding confidential commercial or financial information). If safeguards information is necessary to provide an acceptable response. please provide the level of protection described in 10 CFR 73.21.

Dated at Allington. Texa's

this 21st day of November 1996 
This investigation was initiated by the Nuclear Regulatory Commission (NRC), office of Investigations, Region IV (RIV), on June 6, 1996, to determine whether two Arizona Public Service Company (APS), Palo Verde Nuclear Generating Station (PVNGS), contract employees deliberately provided false information to PVNGS Access Control Section in order to obtain unescorted access.

Based on a review of the licensee internal report, the NRC:RIV inspection report and a summary of the incident by the NRC:RIV technical staff, the allegation that two contract employees deliberately falsified information on their respective Employee Security Questionnaires submitted to PVNGS to obtain unescorted access was substantiated. 


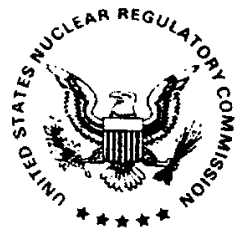

\author{
UNITED STATES \\ NUCLEAR REGULATORY COMMISSION \\ REGION III \\ 801 WARRENVILLE ROAD \\ LISLE. ILLINOIS $60532-4351$
}

August 27, 1996

IA $96-049$

William E. Breen

[HOME ADDRESS DELETED

UNDER 10 CFR 2.790]

\title{
SUBJECT: NOTICE OF VIOLATION AND EXPIRATION OF LICENSE
}

Dear Mr. Breen:

The Nuclear Regulatory Commission (NRC) has received a letter dated August 14, 1996, from the Commonwealth Edison Company (ComEd), informing us that ComEd no longer has a need to maintain your operating license for the Zion Generating Station. We also received a letter from ComEd dated August 16, 1996, containing information about your confirmed positive test for marijuana (copies of both letters are enclosed). We plan to place both of the letters from ComEd in your 10 CFR Part 55 docket file.

In accordance with 10 CFR 55.55(a), the determination by the facility licensee that you no longer need to maintain a license has caused your license (License No. SOP-4020-4) to expire as of August 13, 1996. In addition, the following violation is being issued on your docket (Docket No. 055-7825):

10 CFR $55.53(j)$ provides, in part, that the licensee shall not use, possess, or sell any illegal drugs.

Contrary to the above, on July 9, 1996, the licensee, Mr. William E. Breen, was tested under the Comed fitness-for-duty program resulting in a confirmed positive test for marijuana. (01013)

This is a Severity Level III violation (Supplement I).

The purpose of the Commission's Fitness-for-Duty requirements is to provide reasonable assurance that nuclear power plant personnel work in an environment that is free of illegal drugs and the effects of the use of such substances. The use of illegal drugs is a serious matter which undermines the special trust and confidence placed in you as a licensed operator. This violation is categorized at Severity Level III in accordance with the "General Statement of Policy and Procedure for NRC Enforcement Actions," NUREG-1600, because the use of illegal drugs by licensed operators is a significant regulatory concern. Because your license has expired, you are not required to respond to the Notice of Violation at this time unless you contest the violation. Should you contest the Notice of Violation, a response is required within 30 days of the date of this letter addressing the specific basis for disputing the violation. This response should be sent to the Regional Administrator, NRC Region III, 801 Warrenville Road, Lisle, I1linois 60532-4351 and marked, "Open by Addressee Only." 
The purpose of this letter is to make clear to you the consequences of your violation of NRC requirements governing fitness-for-duty as a 1 icensed operator, in accordance with 10 CFR Part 55. If you reapply for an operating license, you will need to satisfy not only the requirements of 10 CFR 55.31, but also those of 10 CFR 2.201, by addressing the reasons for the violation and the actions you have taken to prevent recurrence in order to ensure your ability and willingness to carry out the special trust and confidence placed in you as a licensed operator and to abide by all fitness-for-duty and other license requirements and conditions.

In accordance with Section 2.790 of the NRC's "Rules of Practice, " Part 2, Title 10, Code of Federal Regulations, enforcement actions are placed in the NRC Public Document Room (POR). A copy of this letter without its enclosures and with your address removed will be placed in the PDR unless you provide a sufficient basis to withdraw this violation within the 30 days specified above for a response to this Notice of Violation.

Should you have any questions concerning this action, please contact Mr. Melvyn Leach of my staff. Mr. Leach can be reached at either the address listed above or telephone number (630) 829-9705.

Sincerely,

/s/ G. E. Grant

Geoffrey E. Grant, Director

Division of Reactor Safety

Docket No. $055-7825$

License No. SOP-4020-4

Enclosures: As Stated

Distribution:

See attached 1 ist 
cc w/o encls: J. H. Mueller, Site Vice President

D. A. Sager, Vice President, Generation Support

H. W. Keiser, Chief Nuclear Operating officer

G. K. Schwartz, Station Manager

W. Stone, Regulatory Assurance Supervisor

D. Farrar, Nuclear Regulatory Services Manager

Richard Hubbard

Nathan Schloss, Economist,

Office of the Attorney General

Mayor, City of Zion

State Liaison Officer, Wisconsin

State Liaison Officer

Chairman, Illinois Commerce

Commission

Document Control Desk-Licensing 


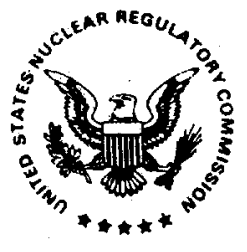

\section{UNITED STATES \\ NUCLEAR REGULATORY COMMISSION \\ REGION IV \\ 611 RYAN PLAZA DRIVE, SUITE 400 \\ ARLINGTON, TEXAS 76011.8064}

September 6, 1996

IA $96-051$

Kirk H. Carroll

Mill Foreman

White Mesa Mill

Energy Fuels Nuclear. Inc.

$6425 \mathrm{~S}$. Highway 191

P. 0. Box 789

Blanding, Utah 84511

SUBJECT: NOTICE OF VIOLATION

(Investigation Report No. 4-96-021)

Dear Mr. Carroll:

This refers to the investigation conducted from May 14, 1996 through July 19. 1996. regarding activities at the White Mesa facility. The investigation was conducted to review the circumstances involving a yellowcake packaging incident which occurred on February 22, 1996. Energy Fuels Nuclear (EFN) informed us of the incident by telephone on February 23, 1996, and subsequently provided us more information by letter dated Apri1 24, 1996: The incident involved you, a mill foreman. "packaging" yellowcake without wearing the required personal protective equipment (PPE). EFN's April 24 letter stated that because of your position in the organization and your failure to demonstrate commitment to the company's ALARA program on that occasion. disciplinary action was taken.

The investigation found that the incident occurred when plant personnel were shutting down the mill and cleaning up the facility. You stated that. during these cleanup activities, you observed a barrel of yellowcake inside the yellowcake packaging room. (Barrels are normally filled with yellowcake by remote control. and PPE is required for entry.) You stated that you entered the room. set a lid on the barrel, and rolled the drum outside for final packaging. without PPE. You also stated that you knew of the procedural requirement to wear PPE, but that you were not thinking - the mill was shutting down. everyone was in a hurry and the barrel needed to be processed. Nonetheless, based on the information developed during the NRC's investigation, the NRC has determined that you deliberately violated plant procedural requirements and EFN's NRC license.

There was no actual safety consequences of your failure to wear PPE under those circumstances. This was due to the fact that yellowcake packaging was not being conducted in an assembly fashion and so there was a small potential for creating airborne exposures. Bioassay results were also less than the action level. However. a deliberate violation of plant procedures by you. an individual above a first line supervisor, is of significant regulatory 
concern. Therefore, your deliberate violation of plant procedures has been categorized in accordance with the "General Statement of Policy and Procedure for NRC Enforcement Actions" (Enforcement Policy). NUREG-1600 at Severity Level III.

The Commission's regulations at 10 CFR 40.10 provide. in part. that any licensee or any employee of a licensee may not engage in deliberate misconduct that causes a licensee to be in violation of any rule, regulation, or order. or any term. condition or limitation of any 1 icense. issued by the Commission. and that any person who violates these requirements may be subject to enforcement action including prohibition from NRC-licensed activities. You should be aware that your actions did not meet the NRC's expectations and caused EFN to be in violation of NRC requirements. The NRC expects full compliance with all applicable NRC requirements and deliberate violation of such requirements wil1 not be tolerated.

Although we recognize that EFN took disciplinary action against you, we have determined that NRC enforcement action against you is warranted. Therefore. I have been authorized, after consultation with the Director. Office of Enforcement to issue the enclosed Notice of Violation (Notice) to you pursuant to 10 CFR 40.10 .

You are required to respond to the enclosed Notice and should follow the instructions when preparing your response. In response to the Notice, you should document the specific actions taken and any additional actions you plan to prevent recurrence. After reviewing your response to the Notice, including your proposed corrective actions, the NRC wi 11 determine whether further NRC enforcement action is necessary to ensure compliance with NRC regulatory requirements.

You must provide your response within 30 days of the date of this letter. In accordance with 10 CFR 2.790 of the NRC's "Rules of Practice." a copy of this letter (with your address removed), its enclosure, and your response will all be placed in the NRC Public Document Room within 45 days, unless you provide sufficient justification for withdrawing this violation. To the extent possible, your response should not include any personal privacy, proprietary. or safeguards information so that it can be placed in the PDR without

redaction. However. if you find it necessary to include such information, you 
should clearly indicate the specific information that you desire not to be placed in the POR. and provide the legal basis to support your request for withholding the information from the public.

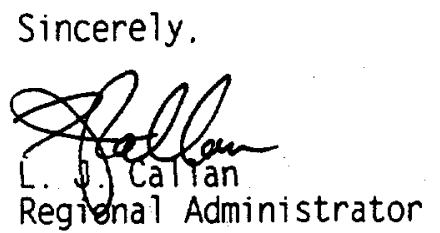

Docket No. $40-8681$

License No. SUA-1358

Enclosure:

Notice of Violation 
Kirk H. Carroll

Docket No. $40-8681$

License No. SUA 1358

IA $96-051$

During an NRC investigation conducted from May 14, 1996 through July 19, 1996. a violation of NRC requirements was identified. In accordance with the "General Statement of Policy and Procedure for NRC Enforcement Actions." NUREG-1600, the violation is listed below:

10 CFR 40.10 states, in part, that any licensee or any employee of a licensee may not engage in deliberate misconduct that causes or, but for detection. would have caused a licensee to be in violation of any rule. regulation, or order, or any term, condition, or limitation of any license issued by the Commission. Deliberate misconduct includes, in part, an intentional act or omission that the person knows: 1) would cause a licensee to be in violation of any rule, regulation or any term. condition, or limitation of any license issued by the Commission: or 2) constitutes a violation of a procedure.

License Condition 29 states, in part, that standard operating procedures (SOPS) shall be established for a 11 operational process activities involving radioactive materials that are handled, processed, or stored. Standard Operating procedures for operational activities shall enumerate pertinent radiation safety practices to be followed.

Section 3.0(c) of White Mesa Operating Procedure. "Yellowcake Precipitation. Drying and Packaging. "Revision 0. states, in part, that full face respirators "must be worn when in the yellowcake dryer enclosure, yellowcake packaging enclosure and when placing lids and rings on filled yellowcake drums to prevent overexposure. № exceptions."

Contrary to the above, on February 22, 1996, Kirk H. Carroll, a mill foreman, entered the yellowcake packaging enclosure. placed a lid on a filled yellowcake drum and rolled the drum outside for final packaging without wearing a full face respirator, although he knew there was a plant procedural requirement to wear one. Mr. Carroll's action caused the licensee to be in violation of its Operating Procedure $3.0(\mathrm{c})$. license condition 29 . (01013)

This is a Severity Level III violation (Supplement VI).

Pursuant to the provisions of 10 CFR 2.201. Kirk H. Carroll is hereby required to submit a written statement or explanation to the Director. Office of Enforcement. U.S. Nuclear Regulatory Commission, within 30 days of the date of this Notice of Violation (Notice). This reply should be clearly marked as a "Reply to a Notice of Violation" and should include for each alleged violation: (1) admission or denial of the alleged violation. (2) the reasons for the violation if admitted, and if denied, the reasons why. (3) the corrective steps that have been taken and the results achieved. (4) the corrective steps that will be taken to avoid further violations. and (5) the 
received within the time specified in this Notice, an order or a Demand for Information may be issued as why such other action as may be proper should not be taken. Consideration may be given to extending the response time for good cause shown.

Because your response will be placed in the NRC Public Document Room (PDR). to the extent possible, it should not include any personal privacy, proprietary, or safeguards information so that it can be placed in the POR without redaction. However. if you find it necessary to include such information, you should clearly indicate the specific information that you desire not to be placed in the PDR. and provide the legal basis to support your request for withholding the information from the public, e.g. provide the information required by 10 CFR 2.790 (b) to support a request for withholding confidential commercial or financial information. If personal privacy or proprietary information is necessary to provide an acceptable response, then please provide a bracketed copy of your response that identifies the information that should be protected and a redacted copy of your response that deletes such information.

Dated at Arlington, Texas.

this 6th day of September 1996 


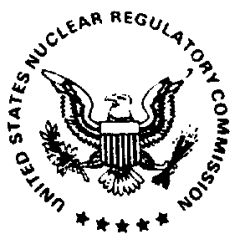

\section{UNITEO STATES \\ NUCLEAR REGULATORY COMMISSION \\ AEGION IV \\ 611 RYAN PLAZA DRIVE, SUITE 400 \\ ARLINGTON, TEXAS 76011-8064}

September 27, 1996

IA $96-061$

Richard Fentiman

[HOME ADDRESS DELETED

PURSUANT TO 10 CFR 2.790]

SUBJECT: NOTICE OF VIOLATION

(NRC TNVEST:SATION REPORT NO. \$-95-059)

Dear Mr. Fentiman:

This is in reference to the matter discussed with you at a predecisional enforcement conference on August 12, 1996, in Kansas City. Missouri. As indicated in our July 25. 1996 letter to you. the purpose of the conference was to discuss an apparent violation of the NRC's rule prohibiting deliberate misconduct and to provide the NRC with information it needed to make an enforcement decision in this case.

Specifically, an investigation was conducted by the NRC's Office of Investigations (OI) into access authorization issues at Cooper Nuclear Station. The investigation confirmed the results of an investigation conducted by your former employer, the Nebraska Public Power District (NPPD). which found that while employed as an access authorization technician at Cooper Nuclear Station, you directed contract personnel to not follow an NPPD procedure. The procedure that was violated. NPPD Procedure AAPP 3.3. "Background Investigations." required access authorization personnel to "develop" two references independent of the references "listed" by the applicant on the request for unescorted access to the facility. The OI investigation determined that you had willfully directed the access authorization workers to use applicant provided "listed" references as access authorization program "developed" references.

At the conference, you acknowledged that you had instructed contract personnel to use "listed" references as "developed" references on limited occasions. particularly when the contract technicians were having difficulty establishing the required developed references. You also acknowledged having instructed them to dispose of the original records submitted by applicants so that you wouldn't have two sets of records in the files. These actions were clearly contrary to NPPD procedures at Cooper Nuclear Station. and contrary to the purpose of conducting background investigations prior to granting unescorted access to the facility. Furthermore, your actions had the potential to result in granting unescorted access to individuals who would not be given access on the basis of a proper background investigation.

Based on our review of the investigation report and the information you provided at the August 12 conference, the NRC has determined that a violation of the NRC's rule on deliberate misconduct, 10 CFR 50.5, did occur. This violation is cited in the enclosed Notice of violation. In accordance with 
the "General Statement of Policy and Procedures for Enforcement Actions." NUREG-1600 (Enforcement Policy). this violation is categorized at Severity Level III.

The NRC notes that you were disciplined by NPPD after this was discovered, and that you voluntarily resigned from NPPD in November 1995. The enclosed Notice of Violation carries with it no additional sanctions, i.e.. the NRC is placing no restrictions on your ability to seek employment in NRC-licensed activities in the future. However. you should be aware that this letter and Notice of Violation will be a matter of public record and will be published in -Nurisg-0y4i, a public compilation of significant agency enforconnont actions whrch is made available to licensees of the NRC and the public. In addition. we expect that if you are re-employed in NRC-licensed activities in the future, that you understand the importance of strict compliance with all requirements and will assure that all procedures are followed.

You are required to respond to this letter and Notice of Violation and should follow the instructions specified in the enclosed Notice.

In accordance with 10 CFR 2.790 of the NRC's "Rules of Practice." a copy of this letter with your home address removed. its enclosure, and your response will be placed in the NRC's Public Document Room (POR). Please contact Gary Sanborn at 817-860-8222 or 800-952-9677 if you have any questions about this matter.

\section{Sincerely.}

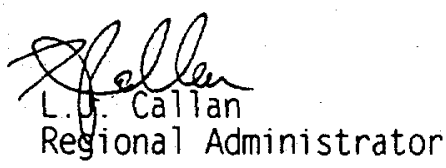

Enclosure: Notice of Violation

Docket No. $\quad 50-298$

License No. OPR-46

CC W/Enclosure:

Guy R. Horn. Vice President - Nuclear

Nebraska Public Power District

1414 15th Street

Columbus. Nebraska 68601

State of Nebraska 
Based on an investigation conducted by the NRC's Office of Investigations, and a report of investigation completed on May 29. 1996 (Case No. 4-95-059). a violation of NRC requirements was ident ified. In accordance with the "General Statement of Policy and Procedure for NRC Enforcement Actions." (Enforcement Policy). NUREG-1600, the violation is set forth below:

10 CFR 50.5(a)(1) states, in part, that any employee of a licensee may not engage in deliberate misconduct that causes cr. but for detection. would riave caused, a iicensee to be in viointion of any rule. regulation. or order, or any term. condition. or limitation of any license, issued by the Commission.

10 CFR 50.5 (c) states, in part, that for purposes of paragraph (a)( 1 ) of this section. deliberate misconduct by a person means an intentional act or omission that the person knows would cause a licensee to be in violation of any rule, regulation. or order. or any term. condition. or limitation. of any license issued by the Commission. or constitutes a violation of a requirement. procedure or policy of a licensee.

Contrary to the above. in October 1995. Richard Fentiman. an employee of Nebraska Public Power District. a licensee, intentionally instructed contract access authorization employees to use references listed by applicants for unescorted access as "developed" references, an instruction which Mr. Fentiman knew was in violation of NPPD policy and procedures for conducting background investigations of applicants. NPPD procedure AAPP 3.3 required that access authorization personnel independently develop two references in addition to those listed by an applicant for unescorted access to the facility. (01013)

This is a Severity Level III Violation (Supplement VII).

Pursuant to the provisions of 10 CFR 2.201. Mr. Fentiman is required to submit a written statement or explanation to the Director. Office of Enforcement. U.S. Nuclear Regulatory Commission within 30 days of the date of this Notice of Violation. This reply should be clearly marked as a "Reply to a Notice of violation" and should include for each alleged violation: (1) the reason for the violation, or. if contested, the basis for disputing the violation. (2) the corrective steps that have been taken and the results achieved. (3) the corrective steps that will be taken to avoid further violations, and (4) the date when full compliance will be achieved. Mr. Fentiman's response may reference or include previous docketed correspondence. if the correspondence adequately addresses the required response. Where good cause is shown. consideration will be given to extending the response time.

Under the authority of Section 182 of the Act 42 U.S.C. 2232, this response shall be submitted under oath or affirmation.

Because the response will be placed in the NRC Public Document Room (PDR), to the extent possible. it should not include any personal privacy. proprietary. 
or safeguards information so that it can be placed in the POR without redaction. If personal privacy or proprietary information that is not already in the public record is necessary to provide an acceptable response. then please provide a bracketed copy of the response that identifies the information that should be protected and a redacted copy of the response that deletes such information. If Mr. Fentiman requests withholding of such material. the request must specifically identify the portions of the response that is requested to be withheld and provide in detail the bases for the claim of withholding (e.g... explain why the disclosure of information will create an unwarranted invasion of personal privacy or provide the information required by 10 CF? 2.790(b) to support 3 request f(r withholding confidentia? ccimercial or financial information).

Dated at Arlington. Texas

this 27th day of September 1996 


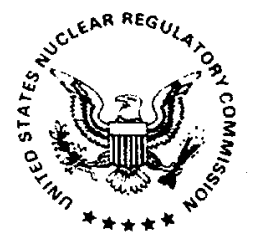

\author{
UNITED STATES \\ NUCLEAR REGULATORY COMMISSION \\ REGION III \\ 801 WARRENMLLE ROAD \\ LISLE. ILLINOIS 60532-4351
}

November 14, 1996

IA $96-072$

Mr. Gregory L. Goodchild

[HOME ADDRESS DELETED

UNDER 10 CFR 2.790]

\title{
SUBJECT: NOTICE OF VIOLATION
}

(NRC Investigation Report No. 3-96-024)

Dear Mr. Goodchild:

This refers to an NRC investigation concerning the circumstances surrounding your violation of NRC requirements while working as a radiochemistry technician at the Point Beach Nuclear Plant.

On April 24, 1996, while working the 5:00 p.m. to 3:00 a.m. shift, you logged in a binder that you had performed a Quality Assurance (QA) check on the Hewlett Packard gas chromatograph (HP5890) at 12:43 a.m. This QA check is required before the first analysis is performed each day in accordance with Technical Specification 15.6.8.1 and Procedure CAMP-107. During the following shift the radiochemistry technicians could not get the gas chromatograph to work properly. While troubleshooting this problem, a portion of the strip chart from the gas chromatograph was located in the trash which clearly indicated that you had not performed the $Q A$ check as logged in the binder. On April 30, 1996, during an interview with the licensee's Production Manager, Chemistry Manager, and day supervisor you maintained that you had performed the QA check after being confronted with evidence to the contrary. Wisconsin Electric subsequently terminated your employment at Point Beach on May 2 , 1996.

Deliberate misconduct is defined in 10 CFR 50.5, (a copy is enclosed) and includes: (1) an intentional act or omission that the person knows would cause a i icensee to be in violation of any rule, regulation, or order, or any term, condition, or limitation of any license issued by the Commission; and (2) deliberate submittal to the NRC or a licensee information that the person submitting the information knows to be incomplete or inaccurate in some respect material to the NRC.

In light of the above, we have concluded that (1) your failure to perform a $Q A$ check on the gas chromatograph on April 24, 1996, in accordance with Technical Specification 15.6.8.1 and Procedure CAMP-107; and (2) your deliberate submittal of incomplete and inaccurate information to the licensee on April 30, 1996, were in violation of 10 CFR 50.5 .

After consultation with the Director, Office of Enforcement, I have decided to issue the enclosed Notice of Violation (Notice) for a violation of 10 CFR 50.5 , while you were engaged in licensed activities at the Point Beach Nuclear Power Plant. In not taking more significant action against you, we recognized 
(1) the minor safety consequences of the violation, (2) that your employment at Point Beach has been terminated, and (3) the level of your former position at Point Beach.

Nevertheless, you should be aware of the seriousness with which the NRC views your actions. The public health, safety, and trust demand that nuclear power plant personnel conduct themselves with integrity at all times. You did not conduct yourself in this manner in this case. In the future, any similar violation may result in more significant enforcement actions including an order prohibiting your involvement in NRC-licensed activities.

You may respond to this letter and, if you choose to respond, you should follow the instructions specified in the enclosed Notice when preparing your response. Your response should provide the NRC with action you plan to take and the reason why the NRC should have confidence that in the future, should you engage in NRC-licensed activities, you will comply with all NRC requirements. Please provide any reply to me at U.S. Nuclear Regulatory Commission, Region III, 801 Warrenville Road, Lisle, Illinois 60532.

In accordance with Section 2.790 of the NRC's "Rules of Practice," Part 2, Title 10, Code of Federal Regulations, records or documents compiled for enforcement purposes are placed in the NRC Public Document Room (POR). A copy of this letter with your address removed, and your response, will be placed in the PDR after 45 days unless you provide sufficient basis to withdraw this letter and Notice of Violation. At that time, a copy will be sent to the Wisconsin Electric Company. To the extent possible, your response should not include any personal privacy, proprietary, or safeguards information so that it can be placed in the POR without redaction.

If you have any questions or comments, please contact Mr. Bruce Burgess of my staff at (630) 829-9666.

Sincerely,

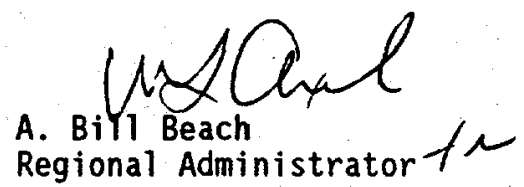

Enclosures:

1. Notice of Violation

2. Deliberate Misconduct Rule, 10 CFR 50.5 
[HOME ADDRESS DELETED

UNDER 10 CFR 2.790]

During an NRC investigation conducted from May 13 through August 28, 1996, a violation of NRC requirements was identified. In accordance with the "General Statement of Policy and Procedure for NRC Enforcement Actions," NUREG-1600, the violation is set forth below:

10 CFR 50.5 provides, in part, that any employee of a licensee who (1) engages in deliberate misconduct that causes a licensee to be in violation of any rule, regulation, or order, or any term condition, or limitation of any license, issued by the Commission, or (2) deliberately submits to the NRC or licensee information that the person submitting the information knows to be incomplete or inaccurate in some respect material to the NRC may be subject to enforcement action in accordance with 10 CFR Part 2, Subpart B.

Technical Specification 15.6.8.1 requires, in part, that the plant be operated and maintained in accordance with approved procedures. Major procedures, supported by minor procedures (such as chemistry analytical procedures) shall be provided for operations where these operations involve nuclear safety.

Procedure CAMP-107, Revision 22, dated December 5, 1995, Steps 6.1 and 6.2.1 requires a QA check of the Hewlett Packard gas chromatograph (HP5890) before the first analysis is performed each day.

Contrary to the above, Mr. Gregory L. Goodchild, a radiochemistry technician employed by Wisconsin Electric Company (1icensee) at the Point Beach Nuclear Plant, (1) engaged in deliberate misconduct when he failed to perform a QA check of the HP5890 at 12:43 a.m. on April 24, 1996, which placed the licensee in violation of Procedure CAMP-107; and (2) deliberately provided false information to the licensee by maintaining that he had performed the QA check after being confronted with evidence to the contrary during an interview with the licensee's Production Manager, Chemistry Manager, and day supervisor on April 30, 1996. The incomplete and inaccurate information was material to the NRC because the licensee relied on the information during its investigation to determine whether a $Q A$ check had been performed in accordance with Technical Specification 15.6.8.1 and Procedure CAMP-107. (01014)

This is a Severity Level IV violation (Supplement I).

Pursuant to the provisions of 10 CFR 2.201, Mr. Mr. Gregory L. Goodchild may submit a written statement or explanation to the U. S. Nuclear Regulatory Commission, ATTN: Document Control Desk, Washington, D. C. 20555 with a copy to the Regional Administrator, NRC Region III, 801 Warrenville Road, Lisle, Illinois 60532, within 30 days of the date of the letter transmitting this Notice of Violation (Notice). The reply should be clearly marked as a "Reply to Notice of Violation" and should include for each violation: (1) the reason for the violation, or, if contested, the bas is for disputing the violation, (2) the corrective steps that have been taken and the results achieved, (3) the corrective steps that will be taken to avoid further violations, and (4) the date when full compliance will be achieved. Your response may reference 
or include previously docketed correspondence, if the correspondence adequately addresses the required response.

Under the authority of Section 182 of the Act, 42 U.S.C. 2232, this response shall be submitted under oath or affirmation.

Your response will be placed in the NRC Public Document Room (PDR) unless you provide sufficient basis to withdraw this Notice.'To the extent possible, your response should not include any personal privacy, proprietary, or safeguards information so that it can be placed in the PDR without redaction. However, if you find it necessary to include such information, you should clearly indicate the specific information that you desire not to be placed in the PDR, and provide the legal basis to support your request for withholding the information from the public.

Dated at Lisle, Illinois

this 14thday of November 1996 
Section 50.5 Deliberate Misconduct

(a) Any licensee or any employee of a licensee; and any contractor (including a supplier or consultant), subcontractor, or any employee of a contractor or subcontractor, of any licensee, who knowingly provides to any licensee, contractor, or subcontractor, components, equipment, materials, or other goods or services, that relate to a licensee's activities subject to this part, may not:

(1) Engage in deliberate misconduct that causes or, but for detection, would have caused, a licensee to be in violation of any rule, regulation, or order, or any term, condition, or limitation of any license, issued by the Commission, or

(2) Deliberately submit to the NRC, a licensee, or a licensee's contractor or subcontractor, information that the person submitting the information knows to be incomplete or inaccurate in some respect material to the NRC.

(b) A person who violates paragraph (a) (1) or (a) (2) of this section may be subject to enforcement action in accordance with the procedures in 10 CFR part 2 , subpart B.

(c) For purposes of paragraph (a) (1) of this section, deliberate misconduct by a person means an intentional act or omission that the person knows:

(1) Would cause a licensee to be in violation of any rule, regulation, or order, or any term, condition, or limitation, of any license issued by the commission, or

(2) Constitutes a violation of a requirement, procedure, instruction, contract, purchase order or policy of a licensee, contractor, or subcontractor.

[56 FR 40690, Aug. 15, 1991] 


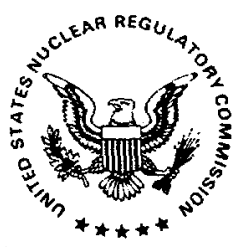

\section{UNITEDSTATES \\ NUCLEAR REGULATORY COMMISSION}

REGION IV

611 RYAN PLAZA DRIVE, SUITE 400

ARLINGTON, TEXAS 76011.8064

December 19, 1996

IA $96-052$

Richard M. Gracin

[HOME ADDRESS DELETED

PURSUANT TO 10 CFR 2.790]

SUBJECT: NOTICE OF VIOLATION

(Investigation Report No. 4-96-004)

Dear Mr. Gracin:

This refers to the investigation conducted by the NRC's Office of Investigations involving a violation of escort-to-visitor ratio into vital areas at the Entergy Operations. Inc. Waterford 3 facility. Based on the investigation, the NRC was concerned that you provided false information concerning the event to the licensee and to an NRC Region IV inspector. A letter documenting the apparent violation was sent to you on September 11. 1996. Our letter provided you with an opportunity to either respond to the apparent violation in writing within 30 days, or request a predecisional enforcement conference within 7 days of the date of the letter. However. as of the date of this letter, we have received no response from you.

Since we have had no response to our September 11. 1996 letter. the NRC has presumed that you chose not to respond. and the NRC has reached a decision based on the information currently available. Based on the information developed during the investigation. the NRC has determined that a violation of NRC requirements occurred. The violation is cited in the enclosed Notice of Violation (Notice). In summary, the violation occurred when you deliberately provided false information to the licensee and to an NRC inspector regarding the timing of your actions as to the number of escorts that were provided with a group of visitors inside the vital area. Specifically, you informed the iicensee and the NRC inspector that you had taken steps to preclude the visitors from entering the plant's vital area on September 12. 1995, thereby preventing a violation. As a result, the NRC inspector relied on that information and concluded that no violation had occurred. However. the licensee later determined that this was not the case. that you knew the visitors were already in the vital area without the required number of escorts, and that you (after-the-fact) took steps to correct the situation.

The NRC notes that you were a security shift supervisor and the NRC expects supervisors to ensure that information provided to the licensee and to the NRC is complete and accurate at all times. A supervisor knowingly providing false information to an NRC inspector and to the licensee is a matter of significant regulatory concern. Therefore, this violation has been categorized in accordance with the "General Statement of Policy and Procedure for NRC Enforcement Actions" (Enforcement Policy), NUREG-1600 at Severity Level III. 
The NRC notes that you were disciplined by Entergy Operations. Inc. after this was discovered, and that you were terminated. The enclosed Notice of Violation carries with it no additional sanctions, i.e. the NRC is placing no restrictions on your ability to seek employment in NRC-licensed activities in the future. However, you should be aware that this letter and Notice of Violation will be a matter of public record and will be published in NUREG-0940, a public compilation of significant agency enforcement actions which is made available to licensees of the NRC and the public. In addition. we expect that if you are re-employed in NRC-licensed activities in the future. that you understand the importance of strict compliance with a 11 requirements and will assure that all procedures are followed.

You are required to respond to this letter and should follow the instructions specified in the enclosed Notice when preparing your response. The NRC will use your response. in part, to determine whether further enforcement action is necessary to ensure compliance with regulatory requirements.

In accordance with 10 CFR 2.790 of the NRC's "RuTes of Practice." a copy of this letter, its enclosure, and your response will be placed in the NRC Public Document Room (PDR).. Should you have any questions regarding this letter. please contact either Michael Vasquez or Gary Sanborn at 1-800-952-9677.

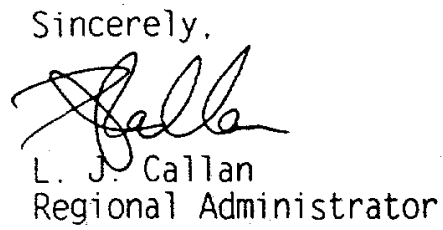

Docket No. $50-458$

License No. NPF-38

Enclosure: Notice of Violation

Cc (w/enclosure):

R. F. Burski

Director. Nuclear Safety

Waterford 3

Entergy Operations. Inc.

P. O. Box B

Killona, Louisiana 70066 


\section{NOTICE OF VIOLATION}

Richard M. Gracin . IA 96-052

During an NRC investigation conducted on January 23 through June 28. 1996. a violation of NRC requirements was identified. In accordance with the "General Statement of Policy and Procedure for NRC Enforcement Actions." NUREG-1600. the violation is listed below:

10 CFR 50.5(a)(2) states, in part. that any employee of a licensee may not deliberately submit to the NRC or the licensee. information that the person submitting the information knows to be incomplete or inaccurate in some respect material to the NRC.

Contrary to the above. on January 11. 1996. Richard M. Gracin. an employee of Entergy Operations. Inc. a licensee, deliberately provided information to an NRC inspector and to licensee representatives that he knew was inaccurate. Specifically, when questioned about the circumstances surrounding a September 12. 1995, event. Mr. Gracin stated that a security officer had stopped two groups of visitors at a vital area door (before entry), and that he (Mr. Gracin) then responded to the door. Mr. Gracin stated that he assigned one security officer to escort one group and a second security officer to the second group to comply with licensee requirements, thereby avoiding a violation. However. several days after providing that information, the licensee discovered that $\mathrm{Mr}$. Gracin had not prevented the violation as he earlier indicated. $\mathrm{Mr}$. Gracin was, in fact, aware that the visitors were in the vital area without the required number of escorts, was cognizant of the escort-tovisitor requirements, and later even took steps to correct the inadequacy. This information was material because it was used to determine whether a violation had occurred. (01013)

This is a Severity Level III violation (Supplement VII).

Pursuant to the provisions of 10 CFR 2.201. Mr. Gracin is required to submit a written statement or explanation to the Director. Office of Enforcement. U.S. Nuclear Regulatory Commission. Washington. OC 20555-0001, within 30 days of the date of this Notice of Violation. This reply should be clearly marked as a "Reply to a Notice of Violation" and should include for each alleged violation: (1) the reason for the violation, or. if contested. the basis for disputing the violation. (2) the corrective steps that have been taken and the results achieved. (3) the corrective steps that will be taken to avoid further violations. and (4) the date when full compliance will be achieved. Mr. Gracin's response may reference or include previous docketed correspondence. if the correspondence adequately addresses the required response. Where good cause is shown. consideration will be given to extending the response time.

Under the authority of Section 182 of the Act 42 U.S.C. 2232. this response shall be submitted under oath or affirmation.

Because the response will be placed in the NRC Public Document Room (PDR). to the extent possible. it should not include any personal privacy, proprietary. or safeguards information so that it can be placed in the POR without redaction. If personal privacy or proprietary information that is not already 
in the public record is necessary to provide an acceptable response. then please provide a bracketed copy of the response that identifies the information that should be protected and a redacted copy of the response that deletes such information. If Mr. Gracin requests withholding of such material. the request must specifically identify the portions of the response that is requested to be withheld and provide in detail the bases for the claim of withholding (e.g.. explain why the disclosure of information will create an unwarranted invasion of personal privacy or provide the information required by 10 CFR $2.790(\mathrm{~b})$ to support a request for withholding confidential commercial or financial information).

Dated at Arlington. Texas

this 19th day of December 1996 


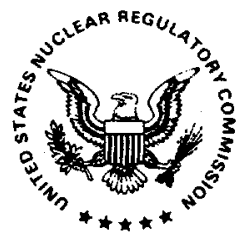

\author{
UNITED STATES \\ NUCLEAR REGULATORY COMMISSION \\ REGION IV \\ 611 RYAN PLAZA DRIVE, SUITE 400 \\ ARLINGTON, TEXAS 76011.8064 \\ October 22,1996
}

IA $96-062$

Mr. David A. Harris

[HOME ADDRESS DELETED

UNDER 10 CFR 2.7901

SUBJECT: NOTICE OF VIOLATION (NRC INVESTIGATION REPORT NO. 4-95-056)

Dear Mr. Harris:

This refers to the investigation conducted by the NRC's Office of Investigations (OOI) at Union Electric's Callaway plant. The investigation was completed in July 1996. The investigation was conducted to review the circumstances surrounding possible tampering with a urine sample submitted for drug testing purposes and to determine whether you were the subject of employment discrimination for identifying concerns related to Callaway's security program.

In October 1995, the NRC was informed by Union Electric that you had been relieved from duty as a contract security shift supervisor based on possible tampering with a urine sample you submitted under Callaway's required Fitness for Duty (FFD) program. Specifically, you submitted a urine sample with a significantly elevated temperature. You were terminated by Burns International Security in November 1995 as a result of this incident. You then alleged to the NRC and in a complaint filed with the U.S. Department of Labor (DOL) that your termination was due, at least in part, to having raised concerns about the Callaway security program. In April 1996, the District Director of the DOL's Wage Hour Division in St. Louis, Missouri, informed you in a letter that the DOL's fact-finding investigation did not substantiate your allegation. You did not file an appeal with the DOL.

Based upon the NRC's investigation of these matters, it appears: 1) that you altered or attempted to substitute a urine sample submitted in response to a random test; and 2) that you were not terminated or otherwise discriminated against as a result of your raising concerns about the Callaway security program. Your attempt to subvert Callaway's FFD program is unacceptable behavior in the nuclear industry. The NRC and its licensees must be able to rely on the integrity and trustworthiness of employees, especially those in a supervisory capacity. At the same time, the NRC recognizes that you were terminated from your job at Callaway as a result of this incident, that you did not test positive for illegal drugs when you were tested immediately after this incident occurred, and that Callaway has not found evidence that you had previously attempted to subvert the testing program.

Based on these considerations, the NRC is issuing to you the enclosed Notice of Violation for your actions, which violated the NRC's rule prohibiting deliberate misconduct, 10 CFR 50.5 . In accordance with the "General Statement of Policy and Procedure for NRC Enforcement Actions," NUREG-1600, the violation in the enclosure has been classified at Severity Level III to reflect the significance of attempting to subvert Union Electric's FFD program. While more significant enforcement action is not being taken against you as a result of the circumstances 
of this case, you should be aware that future violations of the deliberate misconduct rule may result in an order to prevent engaging in licensed activities at all NRC licensed facilities. A violation of this regulation may also lead to criminal prosecution.

You are required to respond to this Notice of Violation and should follow the instructions specified in the enclosed Notice, as applicable to your situation, when preparing your response. For example, where the Notice requires you to address your corrective actions, please address what actions you will take to assure compliance in the future should you be re-employed in the nuclear industry. The NRC will use your response, in part, to determine whether further enforcement action is necessary to ensure compliance with regulatory requirements should you find emiployment in NRC-licensed activities in the future.

In accordance with Section 2.790 of the NRC's "Rules of Practice," Part 2, Title 10, Code of Federal Regulations, records or documents compiled for enforcement purposes are placed in the NRC Public Document Room (PDR). A copy of this letter and enclosure with your address removed, and your response will be placed in the PDR after 45 days unless you provide sufficient basis to withdraw this letter. A copy also will be sent to Union Electric at that time.

If you have any questions, please contact Gary Sanborn, regional Enforcement Officer, at 817 860-8222 or 800-952-9677.

\section{Sincerely,}

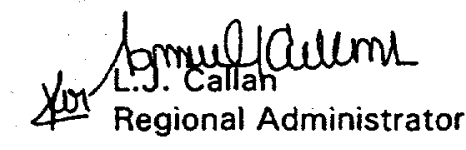

Enclosure: Notice of Violation 


\section{NOTICE OF VIOLATION}

During an NRC investigation completed in July 1996, a violation of NRC requirements was identified. In accordance with the "General Statement of Policy and Procedure for NRC Enforcement Actions," NUREG-1600, the violation is listed below:

10 CFR 50.5 states, in part, that any employee of a contractor of any licensee may not deliberately submit to a licensee information that the person submitting the information knows to be inaccurate in some respect material to the NRC.

Conirary to the above, on September 26, 1995, David A. Harris submitted iniormation (i.e., a urine sample in response to be randomly selected for drug testing) which he knew was inaccurate in some respect material to the NRC. Specifically, Mr. Harris submitted a urine sample that had been altered or tampered with in that its temperature was significantly elevated (it was tested at 123.7 and 124.6 degrees Fahrenheit with two thermometers). The submittal of this sample was material to the NRC because random drug testing is required by NRC regulations in 10 CFR Part 26. (01013)

This is a Severity Level III violation (Supplement VII).

Pursuant to the provisions of 10 CFR 2.201, David A. Harris is hereby required to submit a written statement or explanation to the U.S. Nuclear Regulatory Commission, ATTN: Document Control Desk, Washington, D.C. 20555 with a copy to the Regional Administrator, Region IV, 611 Ryan Plaza Drive, Suite 400. Arlington, Texas 76011, within 30 days of the date of the letter transmitting this Notice of Violation (Notice). This reply should be clearly marked as a "Reply to a Notice of Violation" and should include for each violation: (1) the reason for the violations, or, if contested, the basis for disputing the violation, (2) the corrective steps that have been taken and the results achieved, $(3)$ the corrective steps that will be taken to avoid further violations, and (4) the date when full compliance will be achieved. Your response may reference or include previous docketed correspondence, if the correspondence adequately addresses the required response. If an adequate reply is not received within the time specified in this Notice, an order or a Demand for Information may be issued as to why such other action as may be proper should not be taken. Where good cause is shown, consideration will be given to extending the response time.

Under the authority of Section 182 of the Act, 42 U.S.C. 2232, this response shall be submitted under oath or affirmation.

Because your response will be placed in the NRC Public Document Room (PDR), to the extent possible, it should not include any personal privacy, proprietary, or safeguards information so that it can be placed in the PDR without redaction. If personal privacy or proprietary information is necessary to provide an acceptable response, then please provide a bracketed copy of your response that identifies the information that should be protected and a redacted copy of your response that deletes such information. If you request withholding of such material, you must specifically identify the portions of your response that you seek to have withheld and provide in detail the bases for your claim of withholding (e.g., explain why the disclosure of information will create an unwarranted invasion of personal privacy or provide the information required by 10 CFR $2.790(b)$ to support a request for withholding confidential 
commercial or financial information). If safeguards information is necessary to provide an acceptable response, please provide the level of protection described in 10 CFR 73.21.

Dated at Arlington, Texas

this 22nd day of October 1996 


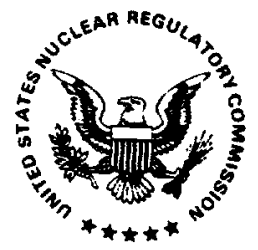

UNITED STATES

NUCLEAR REGULATORY COMMISSION REGION II

101 MARIETTA STREET, N.W., SUITE 2000

ATLANTA, GEORGIA 303230190

November 19, 1996

IA $96-073$

Mr. Roger E. Jones

[HOME ADDRESS DELETED

UNDER 10 CFR 2.790]

\section{SUBJECT: NOTICE OF VIOLATION}

Dear Mr. Jones:

The Nuclear Regulatory Commission (NRC) has received a letter dated October 24. 1996 from the Tennessee Valley Authority informing us of your confirmed positive test for marijuana. A copy of this letter is enclosed for your information (Enclosure 1 - not to be publicly released). We plan to piace this letter in your 10 CFR Part 55 docket file.

This confirmed positive test identified a violation of 10 CFR $55.53(j)$. The purpose of the Commission's Fitness-for-Duty requirements is to provide reasonable assurance that nuclear power plant personnel work in an environment that is free of drugs and alcohol and the effects of the use of these substances. The use of illegal drugs is a serious matter which undermines the special trust and confidence placed in you as a licensed operator. The violation is categorized as a Severity Level III violation in accordance with the "General Statement of Policy and Procedures for NRC Enforcement Actions". NUREG-1600, because the use of illegal drugs by licensed operators is a significant regulatory concern. This violation is described in the enclosed Notice of Violation (Notice). Please note that, in accordance with 10 CFR 26.27(b), future similar violations will substantially affect your authorization for unescorted access to the protected area of a licensed facility.

The purpose of this letter is to make clear to you the consequences of your violation of NRC requirements governing fitness-for-duty as a licensed operator. You are required to respond to this letter and should follow the instructions specified in the enclosed Notice when preparing your response. In your response, you should document the specific actions taken and any additional actions you plan to prevent recurrence in order to ensure your ability and willingness to carry out the special trust and confidence placed in you as a licensed operator of a nuclear power facility. After reviewing your response to this Notice, including your proposed corrective actions. the NRC will determine whether further NRC enforcement action is necessary to ensure compliance with NRC regulatory requirements. 
In accordance with Section 2.790 of the NRC's "Rules of Practice, " Part 2. Title 10, Code of Federal Regulations, enforcement actions are placed in the NRC Public Document Room (PDR). A copy of this letter (without Enclosure 1) and the enclosed Notice of Violation with your address removed wi7l be placed in the PDR after 45 days unless you provide a sufficient basis to withdraw this violation.

Should you have any questions concerning this action, please contact Mr. Thomas A. Peebles of my staff. Mr. Peebles can be reached at either the address listed above or telephone number (404) 331-5541.

Sincerely,

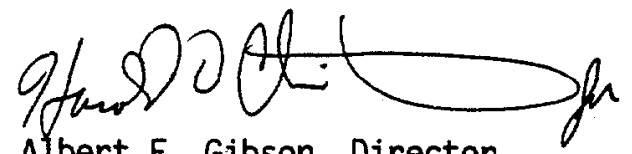

Albert F. Gibson, Director

Division of Reactor Safety

Docket No. $55 \cdot 21779$

License No. OP-20972

Enclosures: 1. October 24, 1996 Letter from Tennessee Valley Authority

2. Notice of Violation

cc w/o encl 1 (HOME ADDRESS DELETED):

Tennessee Valley Authority

ATTN: Mr. Oliver D. Kingsley, Jr.

President, TVA Nuclear and

6A Lookout Place

Chief Nuclear Officer

1101 Market Street

Chattanooga, TN 37402-2801 
Roger E. Jones

[HOME ADDRESS DELETED

UNDER 10 CFR 2.790(a)]
Docket No. 55-21779

License No. OP.20972

IA No. 96 -

As a result of a notification from the Tennessee Valley Authority dated October 24, 1996, a violation of NRC requirements was identified. In accordance with the "General Statement of Policy and Procedures for NRC Enforcement Actions," NUREG-1600, the violation is listed below:

10 CFR $55.53(j)$ prohibits the use of any $i 11$ egal drugs.

Contrary to the above, Mr. Roger E. Jones violated 10 CFR $55.53(\mathrm{j})$ in that he used an illegal drug, marijuana, as evidenced by a confirmed positive test for marijuana resulting from a urine sample collected on September 16, 1996.

This is a Severity Level III violation (Supplement I).

Pursuant to the provisions of 10 CFR 2.201. Mr. Roger E. Jones is hereby required to submit a written statement or explanation to the U.S. Nuclear Regulatory Commission. ATTN: Regional Administrator, Region II, 101 Marietta Street NW, Suite 2900. Atlanta, Georgia 30323, and marked "Open by Addressee Only" with a copy to the Chief, Operator Licensing Branch, Region II and the NRC Resident Inspector at the Browns Ferry Nuclear Power Station, with a similar marking within 30 days of the date of the letter transmitting this Notice of Violation (Notice). This reply should be clearly marked as a "Reply to a Notice of Violation" and should include for each violation: (1) the reason for the violation, or, if soritested, the basis for disputing the violation, (2) the corrective steps that have been taken and the results achieved, (3) the corrective steps that will be taken to avoid further violations, and (4) the date when full compliance will be achieved. If an adequate reply is not received within the time specified in this Notice, an order or a Demand for Information may be issued as to why the license shouid not be modified, suspended, or revoked, or why such other action as may be proper should not be taken. Where good cause is shown, consideration will be given to extending the response time. Under the authority of Section 182 of the Act, 42 U.S.C. 2232, this response sha11 be submitted under oath or affirmation.

Dated at Atlanta, Georgia

this 19th day of November 1996 


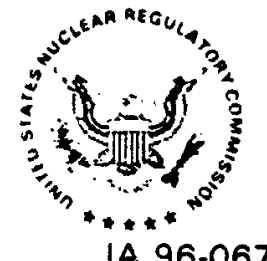

IA. $96-067$

UNITED STATES

NUCLEAR REGULATORY COMMISSION

REGION I

475 ALLENDALE ROAD

KING OF PRUSSIA, PENNSYLVANIA 19406-1415

December 20, 1996

Mr. Michael Muszynski

[HOME ADDRESS DELETED

UNDER 10 CFR 2.7901

\section{SUBJECT: NOTICE OF VIOLATION}

(NRC Investigation Report No. 1-96-013)

Dear Mr. Muszynski:

This refers to the investigation conducted by the NRC Office of Investigations (OI) on April 12, 1996, at the New Britain General Hospital in New Britain, Connecticut. The Ol Synopsis was sent to you with our letter, dated November 5, 1996. That letter provided you with an opportunity to attend a Predecisional Enforcement Conference. On November 13, 1996, a Predecisional Enforcement Conference was conducted with you to discuss the apparent violation, its cause, and your involvement in licensed activities at New Britain General Hospital.

Based on the information developed during the investigation and the information provided during the conference, the NRC has determined that you violated NRC requirements while working at New Britain General Hospital. The violation is cited in the enclosed Notice of Violation (Notice). The NRC Ol investigation report indicated that you had falsified the dose calibrator constancy record on November 29, 1995. You were the Chief Nuclear Medicine Technologist for the hospital at the time the falsification violation occurred, and as such, you caused the licensee to be in violation of 10 CFR 30.9 and 10 CFR 35.50. Therefore, you violated 10 CFR 30.10 , as described in the Notice.

At the conference, you indicated that the readings you recorded were, in fact, the readings you obtained. However, the dose calibrator constancy record was inaccurate in that it indicated that the results of your readings on the barium and cesium settings were approximately $5 \%$ lower than they should have been. The recorded readings for November 29, 1995 were nearly identical to the previous day's readings even though the Radiation Safety Officer had adjusted the barium and cesium settings on the dose calibrator on November 28, 1995, to be $5 \%$ higher when he determined that it was reading approximately $5 \%$ lower than expected based on the activity of the radioactive sources/standards used during the accuracy test. Therefore, the readings obtained by you on November 29,1995 , should have been approximately $5 \%$ higher than what you recorded in the dose calibrator constancy records.

As an individual engaged in NRC licensed activities, and in particular, a first line supervisor, you were in a position that conferred upon you trust and confidence in your ability to ensure that activities were conducted in accordance with requirements, and information required to be maintained by NRC requirements was complete and accurate in all material respects. Your deliberate creation of a false record did not adhere to these standards. As such, this violation constitutes a significant regulatory concern and has been categorized in accordance with the "General Statement of Policy and Procedure for NRC Enforcement Actions" (Enforcement Policyl, NUREG-1600 at Severity Level III. 
Given the significance of your actions, I have decided, after consultation with the Director. Office of Enforcement, to issue to you the enclosed Notice of Violation. I also gave serious consideration as to whether an Order should be issued that would preclude you from any further involvement in NRC-licensed activities for a certain period. However, I have decided, after consultation with the Director, Office of Enforcement, that this Notice of Violation is sufficient since this appears to have been an isolated event, and you are no longer employed by the facility.

You should be aware that the NRC's regulations allow the issuance of orders and other civil sanctions to be taken directly against unlicensed persons who, through their deliberate misconduct, cause a licensee to be in violation of NRC requirements. A violation of the regulation as set forth in 10 CFR 30.10, "Deliberate Misconduct" (Enclosure 3), may also lead to criminal prosecution. You are on notice that any similar misconduct on your part in the future could result in more significant enforcement action against you.

You are required to respond to this letter and should follow the instructions specified in the enclosed Notice when preparing your response. In your response, you should document the specific actions taken and any additional actions you plan to prevent recurrence, and state as your reasons as to why the NRC should have confidence that you will comply with NRC requirements in the future. After reviewing your response to this Notice, including your proposed corrective actions and the results of future inspections, the NRC will determine whether further NRC enforcement action is necessary to ensure compliance with NRC regulatory requirements.

In accordance with 10 CFR 2.790 of the NRC's "Rules of Practice," a copy of this letter, its enclosures, and your response will be placed in the NRC Public Document Room.

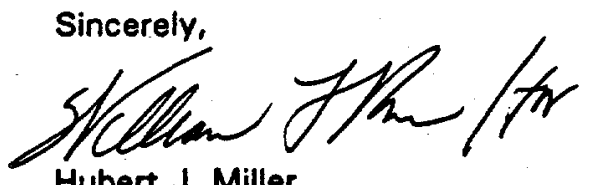

Hubert J. Miller

Regional Administrator

Enclosures:

1. Notice of Violation

2. Notice of Violation to New Britain General Hospital

3. Deliberate Misconduct Rule

cc w/encls:

New Britain General Hospital

NUREG-0940, PART I B-53 
[HOME ADDRESS DELETED

UNDER 10 CFR 2.790]

During an NRC investigation by the NRC Office of Investigations (O1), conducted on April 12, 1996, a violation of NRC requirements was identified. In accordance with the "General Statement of Policy and Procedure for NRC Enforcement Actions," NUREG-1600, the violation is listed below:

10 CFR 30.10 (a)(2) requires, in part, that any employee of a licensee may not deliberately submit to the licensee information that the person submitting the information knows to be incomplete or inaccurate in some respect material to the NRC.

10 CFR 30.9(a) states, in part, that information required by the Commission's regulations to be maintained by the licensee shall be complete and accurate in all material respects.

10 CFR 35.50 requires, in part, that each licensee shall check each dose calibrator for constancy with a dedicated check source at the beginning of each day of use and that the licensee retain a record of each check required by 10 CFR 35.50 for three years unless directed otherwise.

Contrary to the above, on November 29, 1995, Michael Muszynski, an employee of New Britain General Hospital, a licensee of the NRC, deliberately submitted to the licensee information that he knew to be incomplete or inaccurate in some respect material to the NRC. Specifically, Mr. Muszynski recorded on the licensee's dose calibrator constancy record that the readings obtained by him on the barium and cesium settings were approximately $5 \%$ lower than they should have been. This information was inaccurate because, based on the dose calibrator accuracy test and adjustment performed by the Radiation Safety Officer (RSO) on November 28, 1995, the settings had been increased by $5 \%$ on that date and, therefore, the test results recorded by Mr. Muszynski on November 29, 1995, shouid have been approximately $5 \%$ higher. This information was material because it was required to be maintained by NRC regulations. (01013)

This is a Severity Level III violation (Supplement VII).

Pursuant to the provisions of 10 CFR 2.201, you are hereby required to submit a written statement or explanation to the U.S. Nuclear Regulatory Commission, ATTN: Document Control Desk, Washington, D.C. 20555, with a copy to the Regional Administrator, Region I, within 30 days of the date of the letter transmitting this Notice of Violation (Notice). This reply should be clearly marked as a "Reply to a Notice of Violation" and should include for each violation: (1) the reason for the violation, or, if contested, the basis for disputing the violation, (2) the corrective steps that have been taken and the results achieved, (3) the corrective steps that will be taken to avoid further violations, and $(4)$ the date when full 
compliance will be achieved. Your response may reference or include previous docketed correspondence, if the correspondence adequately addresses the required response. If an adequate reply is not received within the time specified in this Notice, an order or a Demand for Information may be issued as to why you should not be prohibited from involvement in NRC licensed activities, or why such other action as may be proper should not be taken. Where good cause is shown, consideration will be given to extending the response time.

Under the authority of Section 182 of the Act, 42 U.S.C. 2232, this response shall be submitted under oath or affirmation.

Because your response will be placed in the NRC Public Document Room (PDR), to the extent possible, it should not include any personal privacy, proprietary, or safeguards information so that it can be placed in the PDR without redaction. However, if you find it necessary to include such information, you should clearly indicate the specific information that you desire not to be placed in the POR, and provide the legal basis to support your request for withholding the information from the public.

Dated at King of Prussia, Pennsylvania

this 20th day of December 1996 


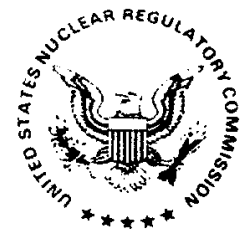

\author{
UNITED STATES \\ NUCLEAR REGULATORY COMMISSION \\ REGION III \\ 801 WARRENVILLE ROAD \\ LISLE. ILLINOIS 60532-4351 \\ July 17, 1996
}

IA $96-040$

Mr. Kipp Rustenholtz

[Home Address Deleted

10 CFR 2.790(a)]

SUBJECT: NOTICE OF VIOLATION

(NRC Investigation Report No. 3-95-025)

Dear Mr. Rustenholtz:

This refers to the investigation conducted by the NRC Office of Investigations (OI) to review possible willful violations of NRC requirements involving South Haven Community Hospital (SHCH), South Haven, Michigan. The investigation concerned the improper receipt of NRC licensed material by you while working as a nuclear medicine technologist (NMT) under contract to SHCH. The investigation concluded that deliberate violations of NRC requirements occurred. The investigation report synopsis was sent to you on April 16, 1996. A transcribed predecisional enforcement conference was held with you on May 6, 1996, at which time you admitted to causing each of the violations.

Based on the information developed during the investigation, the information in a May 13, 1996, letter from SHCH, and the information you provided at the May 6, 1996, conference, the NRC has determined that your deliberate actions caused SHCH to be in violation of several NRC requirements. As a result of your actions, a Notice of Violation is being issued to SHCH (Enclosure 2). In summary: you received NRC-licensed material (technetium-99m) at locations other than SHCH; you failed to measure dosages of technetium-99m prior to administering the material to patients; you prepared inaccurate records by recording calculated dosage activity in place of measured activity, and you falsely annotated a patient dosage record to indicate that a dosage measurement had been made at SHCH when, in fact, the measurement had not been made. NRC acknowledges that each dosage was measured at the nuclear pharmacy prior to dispensing the radiopharmaceutical to SHCH; however, it was the responsibility of SHCH to verify that the proper material and dosage were administered.

The NRC must have confidence that individuals allowed to use radioactive material will do so in a manner that protects public health and safety. The NRC is concerned that you deliberately chose not to implement certain NRC requirements. Given the significance of your actions, I have decided, after consultation with the Director, Office of Enforcement, and the Deputy Executive Director for Nuclear Materials Safety, Safeguards, and Operations Support, to issue to you the enclosed Notice of Violation (Enclosure 1). However, serious consideration was given as to whether an order should be issued that would preclude you from any further involvement in NRC licensed 
activities. Among other considerations, the NRC recognizes that SHCH and your employer took significant disciplinary action against you. Therefore, the NRC is not issuing an Order to you at this time. However, any future violation of 10 CFR 30.10, "Deliberate Misconduct" could lead to more significant civil enforcement action, as well as criminal prosecution.

You are required to respond to this letter and the enciosed Notice and should follow the instructions specified in the enclosed Notice when preparing your response. In your response, you should document the specific actions taken and any additional actions you plan to prevent recurrence. Specifically, you should include a statement of your commitment to compliance with NRC requirements and the basis as to why the NRC should have confidence that you will comply with NRC requirements in the future. After reviewing your response to this Notice, including your proposed corrective actions, the NRC will determine whether further NRC enforcement action is necessary to ensure compliance with NRC regulatory requirements.

Questions concerning this letter and the enclosed Notice may be addressed to Ms. Cynthia D. Pederson, Director, Division of Nuclear Materials Safety, NRC Region III. Ms. Pederson can be reached at telephone number (708) 829-9500.

In accordance with 10 CFR 2.790 of the NRC's "Rules of Practice," a copy of this letter, its enclosure, and your response will be placed in the NRC Public Document Room (PDR). To the extent possible, your response should not include any personal privacy or proprietary information so that it can be placed in the PDR without redaction.

Sincerely,

Enclosures: 1. Notice of Violat ton
2. Notice of Violation to
South Haven Community Hospital

CC w/encl 1:

Mr. Craig J. Marks, President

South Haven Community Hospital 
NOTICE OF VIOLATION

Kipp Rustenholtz

Docket No. 030-32015

License No. 21-26266-01

IA $96-040$

During an NRC investigation violations of NRC requirements were identified. In accordance with the "Statement of Policy and Procedure for NRC Enforcement Actions" (Enforcement Policy), NUREG-1600, the violations are listed below:

I. 10 CFR 30.10(a)(1) requires, in part, that any employee of a licensee or any employee of a contractor or subcontractor of any licensee, shall not engage in deliberate misconduct that causes or, but for detection, would have caused, a licensee to be in violation of any rule, regulation, or order, or any term, condition, or limitation of any license, issued by the Commission.

A. Condition 10.A of NRC License No. 21-26266-01, issued to South Haven Hospital, requires that licensed material be received, stored and used at 955 South Bailey Avenue, South Haven, Michigan.

Contrary to the above, the deliberate actions of Mr. Kipp Rustenholtz, an employee of a contractor of South Haven Community Hospital, caused licensed material, technetium-99m, to be received at locations other than 955 South Bailey Avenue, South Haven, Michigan. Specifically, on February 7, 9, and 14, 1995, Mr. Rustenholtz knew that licensed material could only be received at South Haven Hospital; however, he received technetium-99m in a parking lot at Bronson Methodist Hospital, Kalamazoo, Michigan. (01013)

B. 10 CFR 35.53(a) requires, in part, that a licensee measure the activity of each radiopharmaceutical dosage that contains more than 10 microcuries of a photon-emitting radionuclide before medical use.

Contrary to the above, on April 7, 1994, and February 7, 9, and 14, 1995, Mr. Kipp Rustenholtz, an employee of a contractor of South Haven Community Hospital, knew the requirement to measure radiopharmaceutical dosages containing technetium-99m, a photonemitting radionuclide, before the material was administered to patients for medical use; however, he failed to measure dosages of approximately $9.27,4.7,5.49$, and 6.68 millicuries of technetium$99 \mathrm{~m}$ before administering the dosages to patients at Three Rivers Area Hospital, Three Rivers, Michigan. (02013)

II. 10 CFR 30.10(a)(2) states, in part, that any employee of a licensee or any contractor or subcontractor of any licensee may not submit to the licensee any information that the person submitting the information knows to be incomplete or inaccurate in some respect material to the NRC.

10 CFR 35.53(a) requires, in part, that a licensee measure the activity of each radiopharmaceutical dosage that contains more than 
10 microcuries of a photon-emitting radionuclide before medical use. 10 CFR 35.53 (c) requires that a 1 icensee retain a record of measurements required by section 35.53 for three years.

Contrary to the above, on April 14, 1994, and February 7, 9, and 14, 1995, Mr. Kipp Rustenholtz, an empioyee of a contractor of South Haven Community Hospital, submitted inaccurate information to the licensee. Specifically, Mr. Rustenholtz prepared radiopharmaceutical dosage records by recording calculated rather than measured values for millicurie dosages of technetium- $99 \mathrm{~m}$, a photon-emitting radionuclide, prior to medical use, knowing that dosage measurements were required and that dosage measurements were not made. There was no indication in the records that the recorded values were calculated rather than measured. In addition, Mr. Rustenholtz prepared the February 14, 1995 dosage measurement record by recording "measured at S.H." [South Haven Community Hospital, the licensee] when he knew that the activity of the dosage was not ever measured at South Haven Community Hospital. This information was material because NRC relies on records required by 10 CFR 35.53 (c) to determine the licensee's compliance with section $35.53(\mathrm{a})$. (03013)

This is a Severity Level III problem. (Supplements VI and VII).

Pursuant to the provisions of 10 CFR 2.201, you are hereby required to submit a written statement or explanation to the U.S. Nuclear Regulatory Commission, ATTN: Document Control Desk, Washington, D.C. 20555, with a copy to the Regional Administrator, Region III, 801 Warrenville Road, Lisle, Illinois 60532-4351, within 30 days of the date of the letter transmitting this Notice of Violation (Notice). This reply should be clearly marked as a "Reply to a Notice of Violation" and should include for each violation: (1) the reason for the violation, or, if contested, the basis for disputing the violation, (2) the corrective steps that have been taken and the results achieved, (3) the corrective steps that will be taken to avoid further violations, and (4) the date when full compliance will be achieved. Your response may reference or include previous docketed correspondence, if the correspondence adequately addresses the required response. If an adequate reply is not received within the time specified in this Notice, an order or a Demand for Information may be issued as to why such other action as may be proper should not be taken. Where good cause is shown, consideration will be given to extending the response time.

Under the authority of Section 182 of the Act, 42 U.S.C. 2232, this response shall be submitted under oath or affirmation. 
Because your response will be placed in the NRC Public Document Room (PDR), to the extent possible, it should not include any personal privacy or proprietary information so that it can be placed in the PDR without redaction. However, if you find it necessary to include such information, you should clearly indicate the specific information that you desire not to be placed in the PDR, and provide the legal basis to support your request for withholding the information from the public.

Dated at Lisle, Illinois

the 17 th day of July 1996 


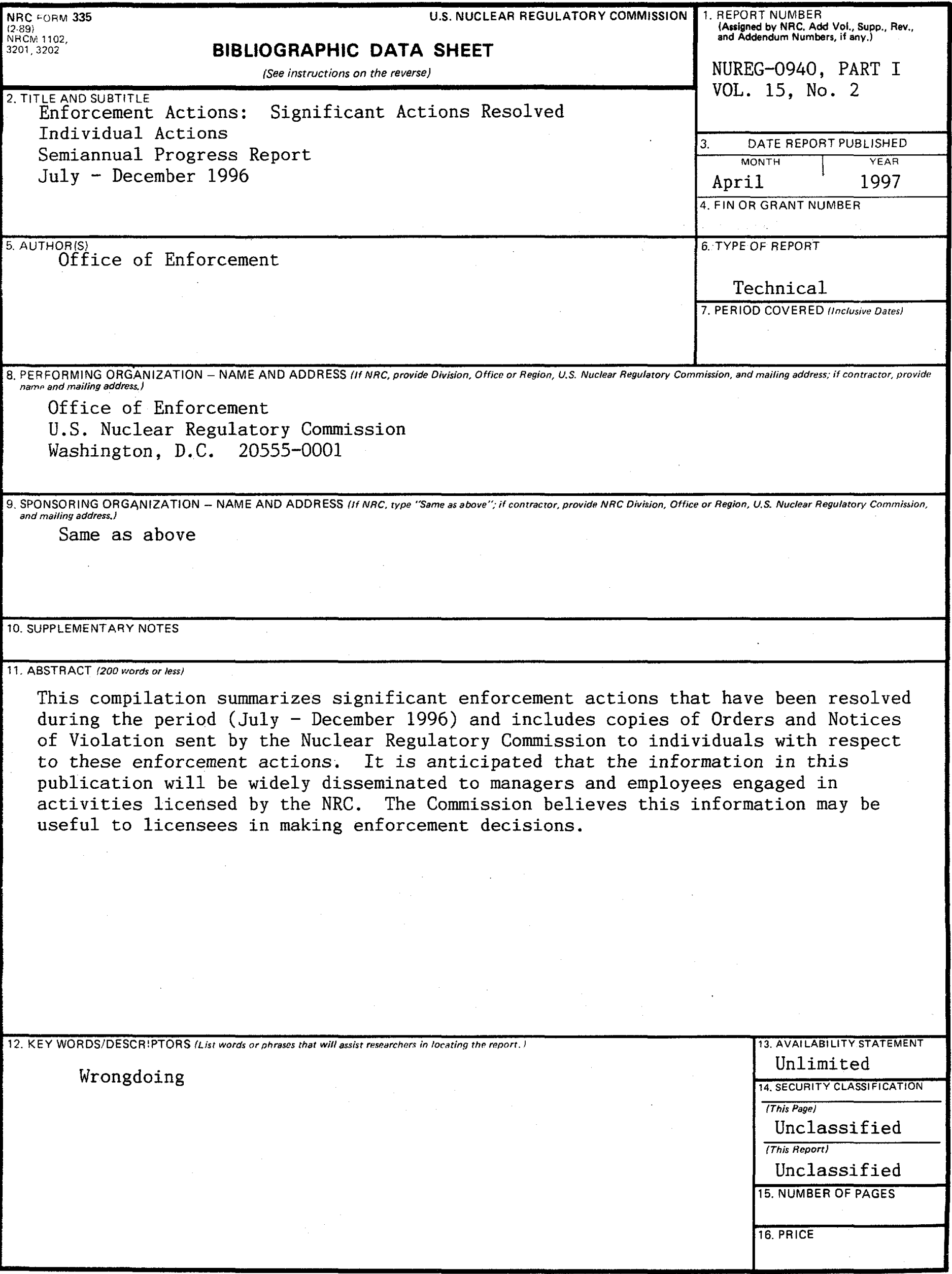




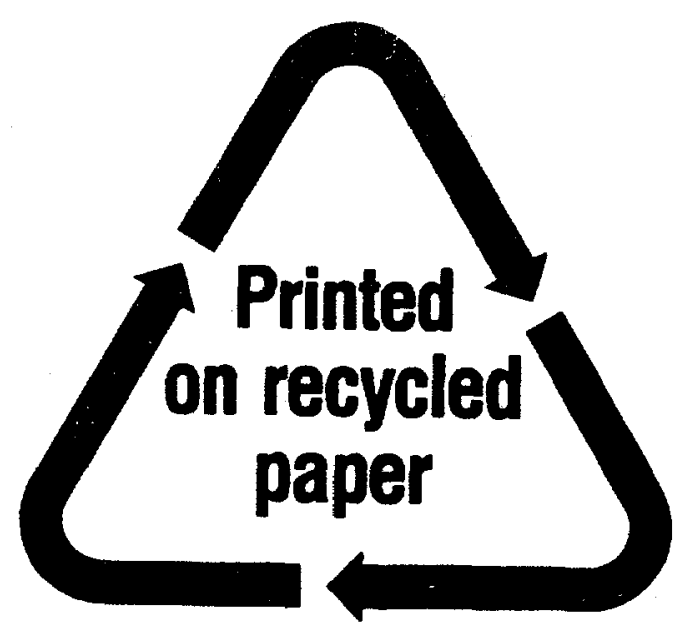

Federal Recycling Program 